\title{
Land Subsidence Due To
}

Ground-Water Withdrawal

in the Los Banos-Kettleman City Area,

California, Part 2. Subsidence and

Compaction of Deposits

GEOLOGICAL SURVEY PROFESSIONAL PAPER 437-F

Prepared in cooperation with the

California Department of Water Resources

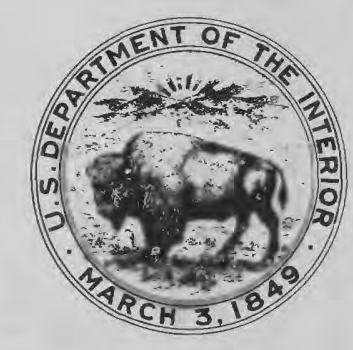




\section{Land Subsidence Due To \\ Ground-Water Withdrawal}

in the Los Banos-Kettleman City Area,

California, Part 2. Subsidence and

Compaction of Deposits

By WILLIAM B. BULL

S T U D I E S O F L A N D S U B S I D E N C E

GE OLOGICAL SURVEY PROFESSIONAL PAPER 437 -F

Prepared in cooperation with the

California Department of Water Resources

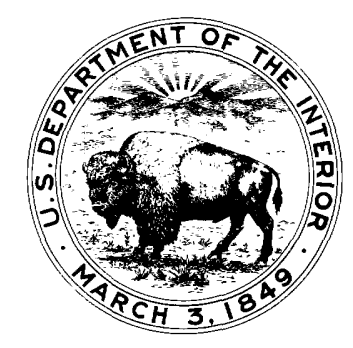

UNITED STATES GOVERNMENT PRINTING OFFICE, WASHINGTON: 1975 


\section{UNITED STATES DEPARTMENT OF THE INTERIOR \\ ROGERS C. B. MORTON, Secretary}

GEOLOGICAL SURVEY

V. E. McKelvey, Director

Library of Congress Cataloging in Publication Data

Bull, William B. 1930-

Land subsidence due to ground-water withdrawal in the Los Banos-Kettleman City area, California.

(Studies of land subsidence) (Geological Survey Professional Paper 437-E-G)

Pt. 2 by W. B. Bull; pt. 3 by W. B. Bull and J. F. Poland.

Includes bibliographies and indexes.

CONTENTS: pt. 1. Changes in the hydrologic environment conducive to subsidence.-pt. 2. Subsidence and compaction of deposits. [etc.]

Supt. of Docs. No.: I 19.16:437-F

1. Subsidences (Earth movements)—California-San Joaquin Valley. 2. Aquifers_California-San Joaquin Valley. 3. Water, Underground-California-San Joaquin Valley. I. Miller, Raymond E. II. Poland, Joseph Fairfield, 1908- III. California. Dept. of Water Resources. IV. Title. V. Series. VI. Series: United States. Geological Survey. Professional Paper 437-E-G.

QE75.P9 No. 437-E-G [GB485.C2]

$557.3^{\prime} 08 \mathrm{~s}\left[551.3^{\prime} 5\right]$

$74-28239$

For sale by the Superintendent of Documents, U.S. Government Printing Office Washington, D.C. 20402

Stock Number 024-001-02610 


\section{CONTENTS}

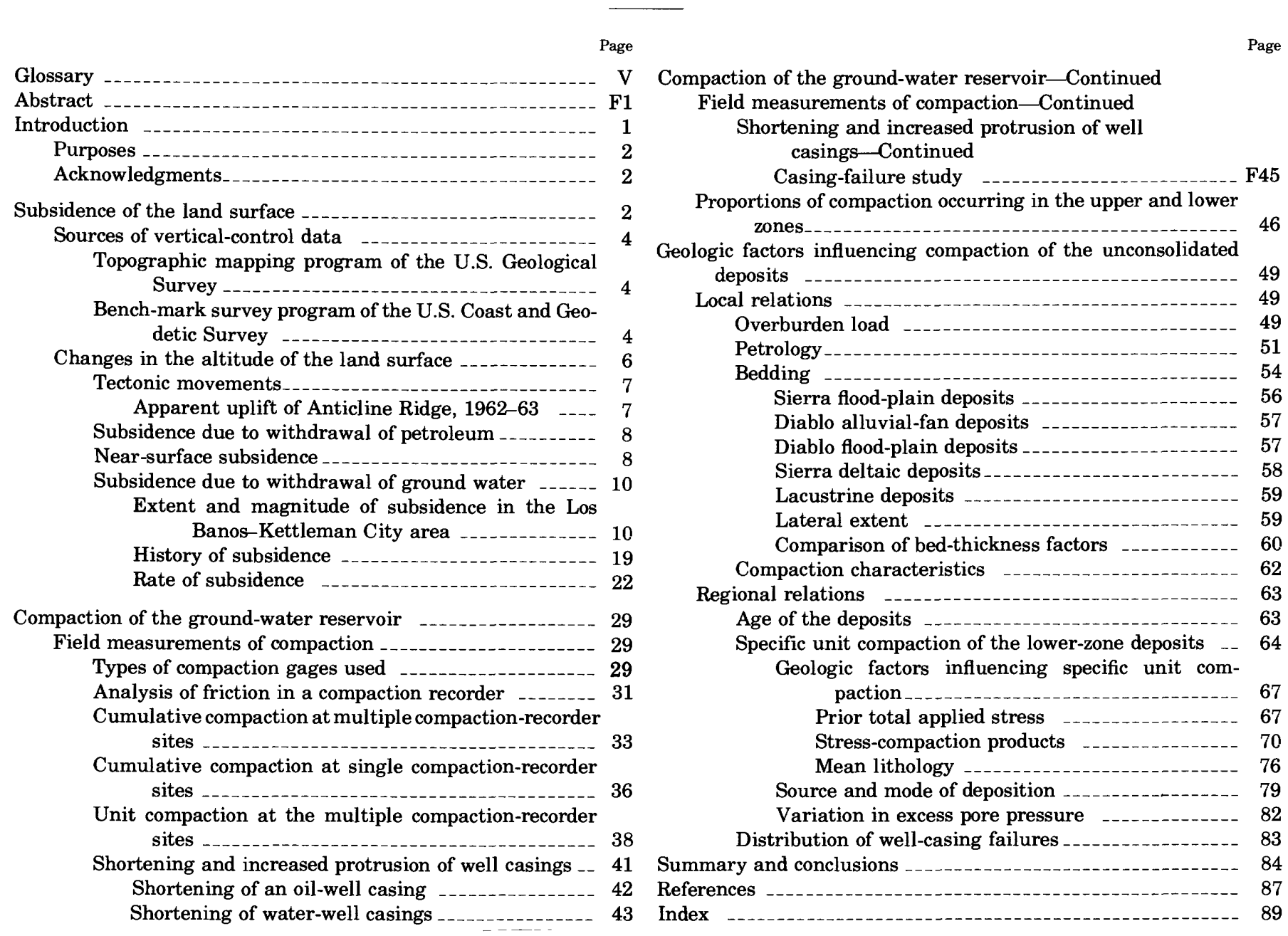

\section{ILLUSTRATIONS}

Figure 1. Map showing bench marks, observation wells, compaction recorders, core holes, and lines of section referred to in this report

2. Map showing level-line network of the U.S. Coast and Geodetic Survey, 1963

3. Maps showing extent and times of principal leveling by the U.S. Coast and Geodetic Survey -...- 8

4. Graph showing apparent net uplift of Anticline Ridge along State Highways 33 and 198, between March 1962 and March 1963

5. Graph showing change in altitude of bench marks in Pleasant Valley (T156), Anticline Ridge (W156), and the west edge of the San Joaquin Valley (Y156), 1933-66

6-13. Maps showing:
6. Location of oil and gas fields in western Fresno County
7. Areas of major land subsidence in the San Joaquin Valley, as of 1963
8. Land subsidence due to artesian-head decline, 1920-28 to 1943
9. Land subsidence, $1920-28$ to 1966
10. Land subsidence due to artesian-head decline, 1943-59
11. Land subsidence, 1955-56
12. Land subsidence, 1959-63

13. Land subsidence, 1963-66 
FIGURE 14. Graph showing distribution of intensity of subsidence, 1920-28 to 1966

15. Graphs showing subsidence for selected bench marks

16. Profile of subsidence that has occurred since 1943, Tumey Hills to Mendota

17. Profile of subsidence that has occurred since 1943, Anticline Ridge to Fresno Slough

18-21. Maps showing:

18. Average yearly rate of subsidence, 1959-63

19. Average yearly rate of subsidence, $1963-66$

20. Change in rate of subsidence between the 1943-53 and 1959-63 periods
21. Change in rate of subsidence between the $1959-63$ and $1963-66$ periods

22. Graphs showing subsidence rates for selected bench marks

23. Diagram of recording compaction gage

24. Diagrammatic sketch of a compaction-recorder system with casing-cable friction

25-35. Graphs showing:

25. Interpolation of part of the cumulative compaction record from well $16 / 15-34 \mathrm{~N} 1$

26. Compaction and subsidence at the Oro Loma site, 1958-66, and Mendota site, 1961-66 ..............

27. Compaction and subsidence at the Cantua site, 1958-66

28. Decrease in the percentage of subsidence measured in the $0-2,000$-foot depth interval at the Cantua site, 1959-67

29. Compaction and subsidence at the Westhaven site, 1962-66, and well 13/12-20D1, 1961-66

30. Compaction and subsidence at well 19/16-23P2, 1959-66

31. Mean annual unit compaction in three depth intervals at the

32. Mean annual unit compaction in two depth intervals at the Mendota site for 2-year periods, 1962-65 -.--

33. Mean annual unit compaction in three depth intervals at the Cantua site for 2-year periods, 1960-65

34. Unit compaction in three depth intervals at the Westhaven site for 1-year periods, 1963-65

35. Decrease in annual compaction for selected depth intervals at multiple compaction-recorder sites -..-...-

36. Photograph showing compressional rupture of an irrigation-well casing

37. Graph showing relation of increased casing protrusion to casing diameter for observation wells that are not gravel packed

38. Diagrammatic sketch of wells used for measuring water levels and compaction, wells 20/18 11Q2 and 11Q3

39. Photograph showing compaction gage and casing separation at wells 20/18-11Q2 (inner casing) and 11Q3 (outer casing)

40-44. Graphs showing:

40. Shortening of $113 / 4$-inch casing, wells $20 / 18-11 \mathrm{Q} 2$ and $11 \mathrm{Q} 3$

41. Subsidence of well bench marks and reference bench marks within 17-193 feet of the well bench mark

42. Effect of pumping on differences of changes in altitudes of reference and well bench marks

43. Unit casing-failure ratio for 50-foot intervals above and below the Corcoran Clay Member of the Tulare Formation

44. Comparison of unit compaction at the Mendota, Cantua, and Westhaven sites and unit casing-failure ratios in the same depth intervals of nearby irrigation wells

45. Map showing proportions of compaction occurring in the upper and lower water-bearing zones -

46. Graphs showing relation of applied stress, sorting, and particle size on void ratio and porosity of selected suites of samples of alluvial sediments from three core holes in the Los Banos-Kettleman City area

47. Electric log of the deposits at well 18/19-20P1

48-52. Graphs showing bedding, lithology, and vertical permeability:

48. Sierra flood-plain deposits, Cantua site, depth 978-1,134 feet

49. Diablo alluvial-fan deposits, Mendota site, depth $350-500$ feet

50. Diablo flood-plain deposits, Mendota site, depth 1,040-1,205 feet

51. Fine-grained facies of the Sierra deltaic deposits, Huron site, depth $2,000-2,114$ feet

52. Corcoran Clay Member of the Tulare Formation and adjacent deposits at the Mendota site, depth $600-721$ feet ..

53-58. Maps showing:

53. Maximum thickness of the perforated interval of the lower zone

54. Specific unit compaction for the lower water-bearing zone, 1943-60

55. Depth to the middle of the lower zone

56. Applied stress due to the unsaturated condition of the deposits above the water table as of 1951 .

57. Seepage stress on the lower zone as of 1943 .

58. Total applied stress on the middle of the lower zone as of 1943

59. Graph showing reduction of the effect of variable effective stress through use of compressibility-effective stress products for core samples from the Cantua site

60. Map showing variations in stress-compaction products

61. Lithofacies map based on the mean corrected resistivities of the lower zone

62. Graph showing variation in mean particle size with depth for alluvial deposits below the Corcoran in cores from the Mendota and Huron sites

63. Graphs showing relation of mean corrected resistivity to the product of specific unit compaction and total applied stress, lower zone

64. Map showing relation of stress-compaction products to the sources and modes of deposition of the lower-zone deposits

F19

20

21

22

23

24

25

27

28

29

32

32

34

35

35

36

37

38

39

40

40

40

41

42 
Figure 65. Section showing relation of stress-compaction products to types of lower-zone deposits

\section{TABLES}

TABLE 1. Summary of compaction-recorder installations

2. Annual compaction rates at multiple compaction-recorder sites

3. Variation in the deepest annual water levels for selected depth zones at the multiple compaction-recorder sites, 1959-63

4. Proportions of compaction occurring in the upper and lower water-bearing zones

5. Amount of clay in deposits from Diablo and Sierra sources in the Mendota, Cantua, and Huron cores

6. Mean vertical permeabilities of the different types of deposits as determined from consolidation tests of samples in the load range $400-800 \mathrm{lb} \mathrm{in}^{-2}$ at the four core-hole sites

7. Summary of lower-zone weighted mean bed-thickness factors of aquitards for types of deposits and Inter-Agency Committee core-hole sites

8. Weighted mean bed-thickness factors of aquitards for lower-zone deposits at Inter-Agency Committee core-hole sites 6

9. Mean consolidation characteristics of the Corcoran and the different types of lower-zone deposits in the load range $400-800 \mathrm{lb}$ in $^{-2}$

\section{GLOSSARY}

The geologic and engineering literature contains a variety of terms that have been used to describe the processes and environmental conditions involved in the mechanics of stressed aquifer systems and of land subsidence due to withdrawal of subsurface fluids. The usage of certain of these terms in reports by the U.S. Geological Survey research staff investigating mechanics of aquifer systems and land subsidence is defined and explained in a glossary published separately (Poland and others, 1972). Several terms that have developed as a result of the Survey's investigations are also defined in that glossary.

The aquifer systems that have compacted sufficiently to produce significant subsidence in California and elsewhere are composed of unconsolidated to semiconsolidated clastic sediments. The definitions given in the published glossary are directed toward this type of sediments; they do not attempt to span the full range of rock types that contain and yield ground water. In defining the components of the compacting stresses, the contribution of membrane effects due to salinity or electrical gradients has been discounted as relatively insignificant in the areas studied.

In our research reports, pressures or stresses causing compaction are usually expressed in equivalent "feet of water head" ( 1 foot of water $=0.433 \mathrm{lb} \mathrm{in}^{-2}$ (pounds per square inch)).

A committee on redefinition of ground-water terms, composed of - members of the Geological Survey, recently issued a report entitled "Definitions of Selected Ground-Water Terms" (Lohman and others, 1972). The reader is referred to that report for definitions of many ground-water terms.
Five terms used in this report which have not been defined elsewhere are given in the following list.

APPARENT COMPRESSIBILITY. A time-dependent parameter derived from field observations that indicates the amount of shortening, per unit thickness of deposits, per unit change in applied stress. Parameters such as specific unit compaction and stress-compaction products are apparent compressibilities because the degree to which applied stresses have become effective is not known.

COMPRESSIBILITY-EFFECTIVE STRESS PRODUCT. The product of compressibility and effective stress, as determined by laboratory consolidation tests. The resulting product is a true compressibility for which the effects of variable effective stress have been largely eliminated.

CRITICAL DEPTH. The depth below which friction between the casing and the adjacent deposits exceeds the shear strength of the casing.

STRESS-COMPACTION PRODUCT. An apparent compressibility for which the effect of prior total applied stress has been removed. In this paper, the stress-compaction product was computed by multiplying specific unit compaction by total applied stress. The resulting product is only an apparent compressibility of the deposits, because the degree to which applied stresses have become effective is not known.

SUBSIDENCE, NEAR-SURFAGE. The vertical downward movement of the land surface that occurs when moisture-deficient deposits compact as they are wetted for the first time since burial (Bull, 1964a). 


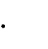




\title{
LAND SUBSIDENCE DUE TO GROUND-WATER WITHDRAWAL IN THE LOS BANOS-KETTLEMAN CITY AREA, CALIFORNIA, PART 2. SUBSIDENCE AND COMPACTION OF DEPOSITS
}

\author{
By William B. Bull
}

\section{ABSTRACT}

Pumping of ground water has increased the stresses tending to compact unconsolidated deposits by as much as $\mathbf{5 0}$ percent, thereby creating the world's largest area of intense land subsidence in the west-central San Joaquin Valley, Calif. As of 1966, 2,000 square miles had subsided more than 1 foot, and the area that had subsided more than 10 feet was 70 miles long. Maximum subsidence was 26 feet. Subsidence rates increased until the mid-1950's when the maximum observed rate was $1.8 \mathrm{ft} \mathrm{yr}^{-1}$ (feet per year), but have decreased since then. During the 1963-66 period the maximum subsidence rate was

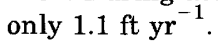

Subsidence due to artesian-head decline is of greater extent and magnitude than three other types of subsidence in the area. Tectonic subsidence is difficult to separate from other types of subsidence. Net uplifts of less than 0.1 foot have occurred at three places at the front of the Diablo Range. Subsidence due to pumping of petroleum appears to be minor. The Coalinga oil field subsided only 0.25 foot in 20 years. About 120 square miles adjacent to the Diablo Range is susceptible to near-surface subsidence, where compaction due to wetting of moisture-deficient alluvial-fan deposits has caused as much as 15 feet of subsidence. Subsidence of 3-10 feet is common.

Subsidence due to artesian-head decline occurred first in the northern part of the area, where, by 1943, subsidence was as much as 10 feet. By 1963, 20 feet of subsidence had occurred in both the northern and southern areas. Maximum subsidence, as of 1968, was estimated to be 28 feet.

Special compaction recorders in wells penetrating most of the aquifer system tapped by wells initially measured as much as 99 percent of the subsidence. Since 1963, most recorders have been measuring progressively less of the subsidence, which indicates that compaction due to pore-pressure decline is occurring at greater depths than previously.

Unit compaction of as much as $1.2 \times 10^{-3}$ feet per foot per year has been measured at the Cantua site. Casing-failure distribution indicates that amounts of unit compaction increase to depths of roughly 200 feet below the Corcoran Clay Member of the Tulare Formation in response to progressively larger head declines with depth. Below a depth of about 200 feet below the Corcoran, unit compaction decreases with depth, probably in response to minimal change of head decline with depth and to the decreasing compressibilities of the deposits caused by progressively greater prior effective stresses.

Compaction mainly shortens water-well casings, but also causes increased casing protrusion above the land surface of as much as 10 percent of the compaction. Bench marks within 17-193 feet of active irrigation wells subside less than the tops of the well casings despite increased casing protrusion. Maximum compaction occurs at pumping wells, because they are points of maximum applied stress.
In most of the area about 70-95 percent of the compaction occurs in the lower zone below the Corcoran confining bed. As much as $30-40$ percent of the compaction occurs in the upper zone in the southern part of the area.

Geologic factors that cause differences in specific unit compaction include total applied stress, lithofacies, and source and mode of deposition-factors that were assessed by removing the effect of prior load. The specific unit compaction of the lower-zone deposits, 1943-60, in the northern part of the area is four times that in the central and southern parts of the area, suggesting a marked difference in the compressibility of the deposits. About one-third of the apparent difference in compressibilities between the northern and southern areas is real and is due to differences in total applied stress prior to 1943. Deeply buried deposits that have been subjected to large prior applied stresses are less compressible, per unit of additional stress increase, than are deposits at moderate depths.

The other two-thirds of the compressibility difference is only apparent and is attributed chiefly to hydraulic differences between genetic types of deposits that affect the rate of expulsion of water from aquitards for a given applied-stress increase. When compared with the Diablo (derived from Diablo Range) and Sierra (derived from Sierra Nevada) flood-plain deposits, the Diablo alluvial-fan deposits have a higher clay content and are more poorly sorted, which results in lower permeabilities and slower consolidation rates. Fine-grained beds generally are thicker in the lacustrine and fan deposits than in the flood-plain deposits. (Respective mean bed-thickness factors are 61,24 , and 14 , where bed-thickness factor is (aquitard thickness/2) ${ }^{2}$ ). Thus, conditions in the alluvial-fan aquitards in the southern part of the area and thick lacustrine sequences in the central part of the area are favorable for development of large residual excess pore pressures and high values of ultimate specific unit compaction. These same conditions also are responsible, in part, for the lower apparent compressibilities (stress-compaction products) during the 1943-60 period in the areas of thick alluvial-fan and lacustrine deposits than in the areas of thick flood-plain deposits.

Variations in the mean lithology (corrected mean resistivities) of the lower zone are not as important as either prior overburden load or mode of deposition in determining the apparent compressibilities of the deposits.

\section{INTRODUCTION}

By increasing the stress tending to compact the unconsolidated deposits by as much as 50 percent, man has created the world's largest area of intense land subsidence in the west-central San Joaquin Valley. Withdrawal of ground water for agriculture has caused more than 2,000 square miles to subside more than 1 foot. As 
of 1966, the area that had subsided more than 10 feet was 70 miles long, and the maximum subsidence was 26 feet. The land subsidence, compaction of the saturated deposits that caused the subsidence, and the geologic factors influencing the compaction-which are the topics of this paper-will be presented for one of four major areas of intense land subsidence due to ground-water withdrawal in California.

This paper is the second of three reports discussing land subsidence due to ground-water withdrawal in the Los Banos-Kettleman City area, California. Part 1 (Bull and Miller, 1974) is a factual presentation of the hydrologic factors conducive to land subsidence in the study area. Part 3 (Bull and Poland, 1974) discusses the interrelations of water-level change, change in aquifer-system thickness, and the concurrent changes in land-surface altitude as well as the criteria for prediction of subsidence.

The introduction to all three parts can be found in Part 1 (Bull and Miller, 1974). That introduction includes descriptions of the extent of the study area and the geographic setting, as well as sections about the Inter-Agency Committee on Land Subsidence and the scope of the field and laboratory work for the Cooperative and Federal subsidence programs. The principal areas of land subsidence in California due to groundwater withdrawal and the topographic and cultural features of the Los Banos-Kettleman City subsidence area are shown in figures 1 and 2 of Part 1 (Bull and Miller, 1974). For a résumé of the hydrologic environment and the man-induced changes in the hydrologic environment, the reader is referred to the summary and conclusions of Part 1.

The boundaries of the Los Banos-Kettleman City study area, bench marks, observation wells, compaction recorders, core holes, and lines of section referred to in this report are shown in figure 1 . The northeast boundary as shown in figure 1 is along the valley trough, but as of 1966, as much as 8 feet of subsidence had occurred east of the valley trough. Therefore, in much of the study, the 1-foot subsidence line (figs. 9, 14) was used as the east boundary of the subsidence system.

The bulk of the information presented in this paper concerns the events before April 1966, which was a time of complete leveling of the bench-mark network by the U.S. Coast and Geodetic Survey (since 1970, the National Geodetic Survey, a component of the National Ocean Survey). Where post-March 1966 data are presented and discussed, it is done only to present facts or concepts that cannot be demonstrated with the earlier data.

\section{PURPOSES}

The scope of this paper is to discuss the compaction of unconsolidated deposits and the resulting land subsid- ence in the many different geologic and hydrologic environments present in the west-central San Joaquin Valley. Within this scope, the paper has three specific purposes. The first is to show the extent, magnitudes, and rates of subsidence due to artesian-head decline; to show the changes of these aspects during the agricultural development of the area; and to compare the extent, magnitudes, and rates of subsidence due to artesian-head decline with concurrent subsidence caused by compaction due to wetting, withdrawal of petroleum, and tectonic activity. The second purpose is to describe the measurement of compaction, the proportions of subsidence being measured by compaction recorders, and the rates and amounts of compaction occurring within specific depth intervals. The third purpose of this paper is to assess the geologic factors influencing compaction of the deposits of differing lithology, source, mode of deposition, and depth of burial. Both those geologic factors described in the literature and consideration of new factors will be included in the geologic appraisal of compaction.

\section{ACKNOWLEDGMENTS}

The cooperation of numerous ranchers, landowners, and companies is acknowledged for supplying essential information to the subsidence project and for giving permission to install and maintain wells and equipment for obtaining water-level and compaction information. Particular assistance was given by the Pacific Gas and Electric Co., Westlands Water District, and Russell Giffen, Inc.

The financial cooperation of the California Department of Water Resources made this study possible, and information provided by the U.S. Bureau of Reclamation from core holes and observation wells contributed significantly to the essential data.

This work could not have been completed without the discussions, interest, and assistance of many people who have been associated with the land-subsidence studies since 1956. I appreciate particularly the helpful discussions and review of the manuscript by the project chief, J. F. Poland, and my colleagues, G. H. Davis, B. E. Lofgren, and F. S. Riley. I enjoyed working together with R. L. Ireland and R. G. Pugh on a variety of jobs in the field and appreciate their extensive help in collection and assembling of field data. Particular credit is due Mr. Ireland for his meticulous care and thoughtful foresight in the installation and operation of the equipment for recording compaction and water-level changes during the entire period of record.

\section{SUBSIDENCE OF THE LAND SURFACE}

Several parts of the Los Banos-Kettleman City area have subsided more than 20 feet, and subsidence rates 


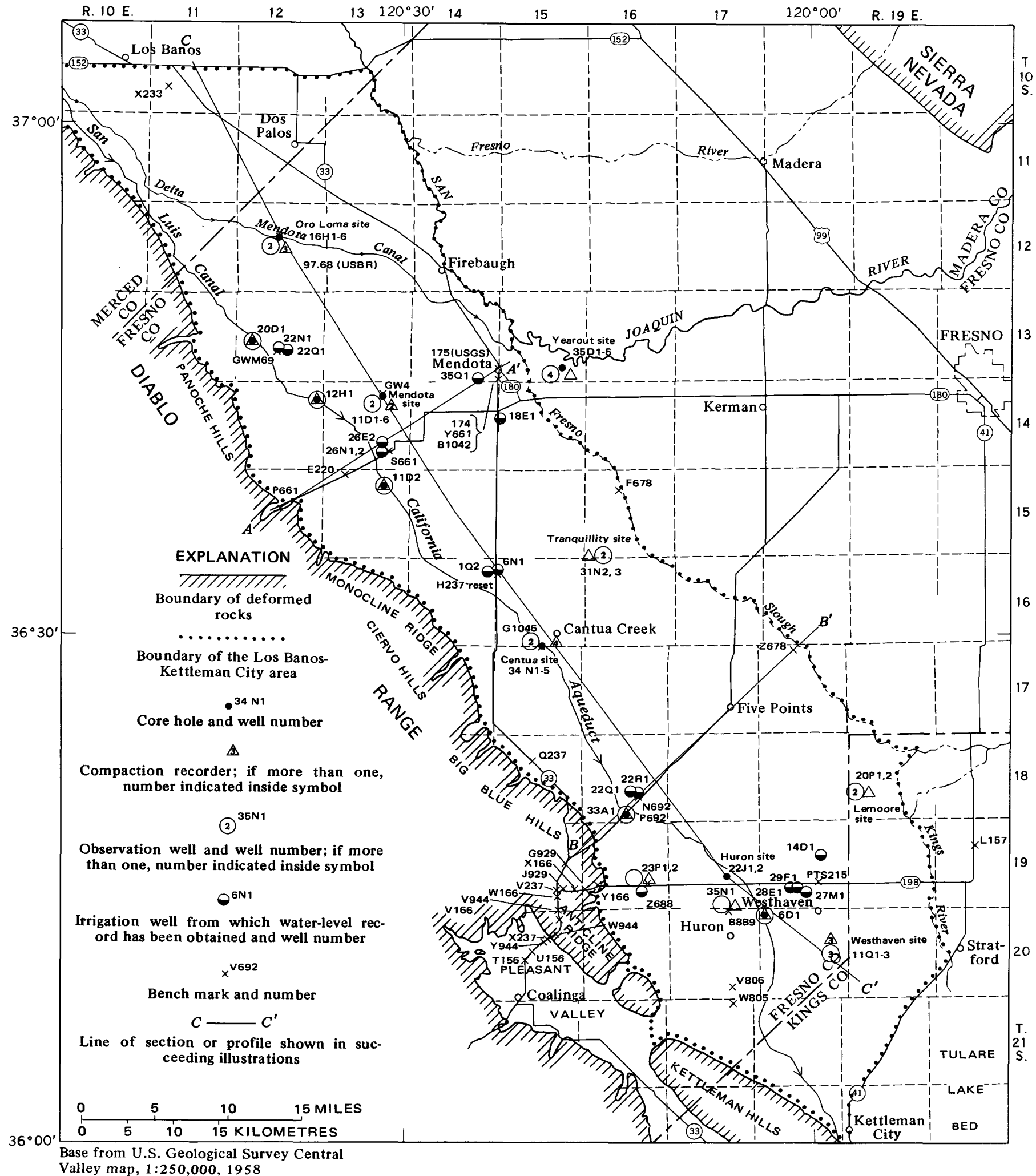

FIGURE 1.-Bench marks, observation wells, compaction recorders, core holes, and lines of section referred to in this report.

have exceeded $1 \mathrm{ft} \mathrm{yr}^{-1}$ (foot per year). The main pur- $\mid$ Three other types of subsidence also will be discussed to pose of this section is to discuss the extent, rate, and indicate their extent, rate, and magnitude in relation to magnitude of subsidence due to artesian-head decline. the areas of subsidence due to artesian-head decline. 


\section{SOURCES OF VERTICAL-CONTROL DATA}

The two main sources of vertical-control data are maps made by the Geological Survey and bench-mark altitudes of the Coast and Geodetic Survey. The Bureau of Reclamation and the California Department of Water Resources also have surveyed bench marks along canals and future canal alinements.

TOPOGRAPHIC MAPPING PROGRAM OF THE U.S. GEOLOGICAL SURVEY

The first detailed topographic mapping of $71 \frac{1}{2}$-minute quadrangles in the Los Banos-Kettleman City area was done mainly during the 1920 's. Surveys for detailed topographic maps were made in the following periods: between latitudes $36^{\circ} 30^{\prime}$ and $37^{\circ} 00^{\prime}, 1919-23$; between $36^{\circ} 15^{\prime}$ and $36^{\circ} 30^{\prime}, 1924-28$; and between $36^{\circ} 00^{\prime}$ and $36^{\circ} 15^{\prime}, 1926-33$. These maps had a 5- or 10-foot contour interval based on planetable surveys.

The Geological Survey was first confronted with the subsidence problem in the Los Banos-Kettleman City area in 1953-54 when a map revision program was undertaken (Inter-Agency Committee on Land Subsidence in the San Joaquin Valley, 1958, p. 33-35). Normally a revision for the purpose of bringing culture up to date would not present many problems. However, the surveyors had difficulty in closing stadia traverses and in reconciling topography with cultural changes. It was apparent that a useful topographic map for engineering purposes would not result from a mere cultural revision.

The situation was brought to the attention of the members of the Inter-Agency Committee, and it was agreed that completely new topographic maps were necessary to show the amount of subsidence that had occurred since the 1920's, especially for large areas between the existing level lines. The Coast and Geodetic Survey gave full cooperation to a coordinated program of establishing vertical control for the areas to be remapped topographically. The topographic mapping immediately followed the leveling of SeptemberNovember 1955 , and 28 quadrangles were remapped during the winter of $1955-56$; by 1962,43 maps within, or partly in, the Los Banos-Kettleman City area had been revised and then remapped where necessary. The contour interval for these maps ranges from 5 to 40 feet.

A comparison of the maps made in the 1920's and the 1950 's showed that more than 10 feet of subsidence had occurred over large areas and that the maximum subsidence was about 18 feet in an area west of Mendota. Because of the large areas between level lines prior to 1955, this comparative subsidence map is used, in part, for all the subsidence maps that portray subsidence prior to 1955 . Maps that portray only post-1955 subsidence are based entirely on bench-mark control.
BENCH-MARK SURVEY PROGRAM OF THE U.S. COAST AND GEODETIC SURVEY

The Coast and Geodetic Survey has been the key agency in fulfilling the following vertical-control elements proposed by the Inter-Agency Committee on Land Subsidence in the San Joaquin Valley (1955, p. 16-17).

1. Maintenance of a basic network of first-order levels surrounding the San Joaquin Valley, with crossties between bedrock in the Sierra Nevada, Coast Ranges, and Tehachapi Mountains, and to oceantide gages. (This network provides an overall datum and helps determine the general stability of the local bedrock reference points.)

2. Establishment of a network of first- and second-order levels within the basic network to form a base for topographic mapping and special surveys, which will provide information on the extent of subsidence areas and on the development of new subsidence areas.

3. Periodic releveling of a comprehensive network of lines in the areas of known major subsidence to define the amount and rate of subsidence. (The Los Banos-Kettleman City area was releveled every 2 years between 1955 and 1959 and every 3 years between December 1959 and March 1966.)

The level-line network of the Coast and Geodetic Survey is shown in figure 2 , which also shows the quadrangle boundaries and numbers. Only part of the lines outside of the Los Banos-Kettleman City area are shown. Additions to this network have not been proposed except for short spur lines to compaction recorders.

The first Coast and Geodetic Survey leveling in the Los Banos-Kettleman City area was made in 1933 (prior levelings were made by the Geological Survey) and was followed by releveling or new leveling in 1935, 1942-43, 1947, 1948, and in every year from 1952 through 1968 except 1956 and 1961 . In some of these years, the extent of the leveling was small because the work consisted mainly of establishing bedrock ties for work being done outside the Los Banos-Kettleman City area. The extent of the eight principal levelings is shown in figure 3 . The complete subsidence network that was established in 1955 has been releveled four times, the latest being in the winter of 1966 .

Leveling accuracy is difficult in an area that subsides as rapidly as the Los Banos-Kettleman City area. Attainment of precise results is hindered by movement of reference bench marks within the mountains and by subsidence of bench marks during the leveling of the valley areas. For purposes of adjusting the results of a leveling program, certain bench marks set in bedrock 


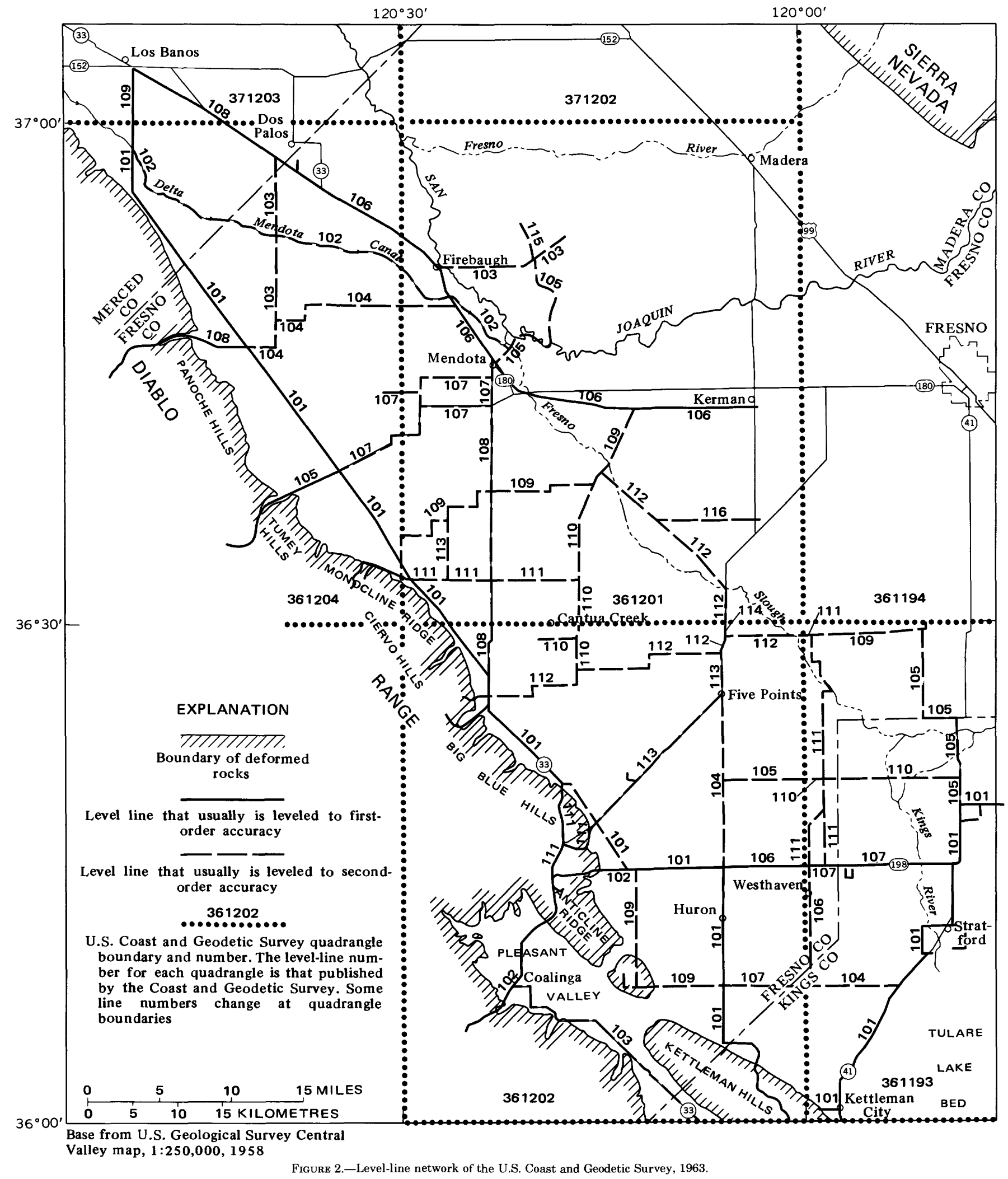

within the mountains are regarded as stable (not un- $\mid$ subsidence network to bench marks set in bedrock at dergoing changes in altitude). It is important to tie the several places because, in general, bench-mark move- 


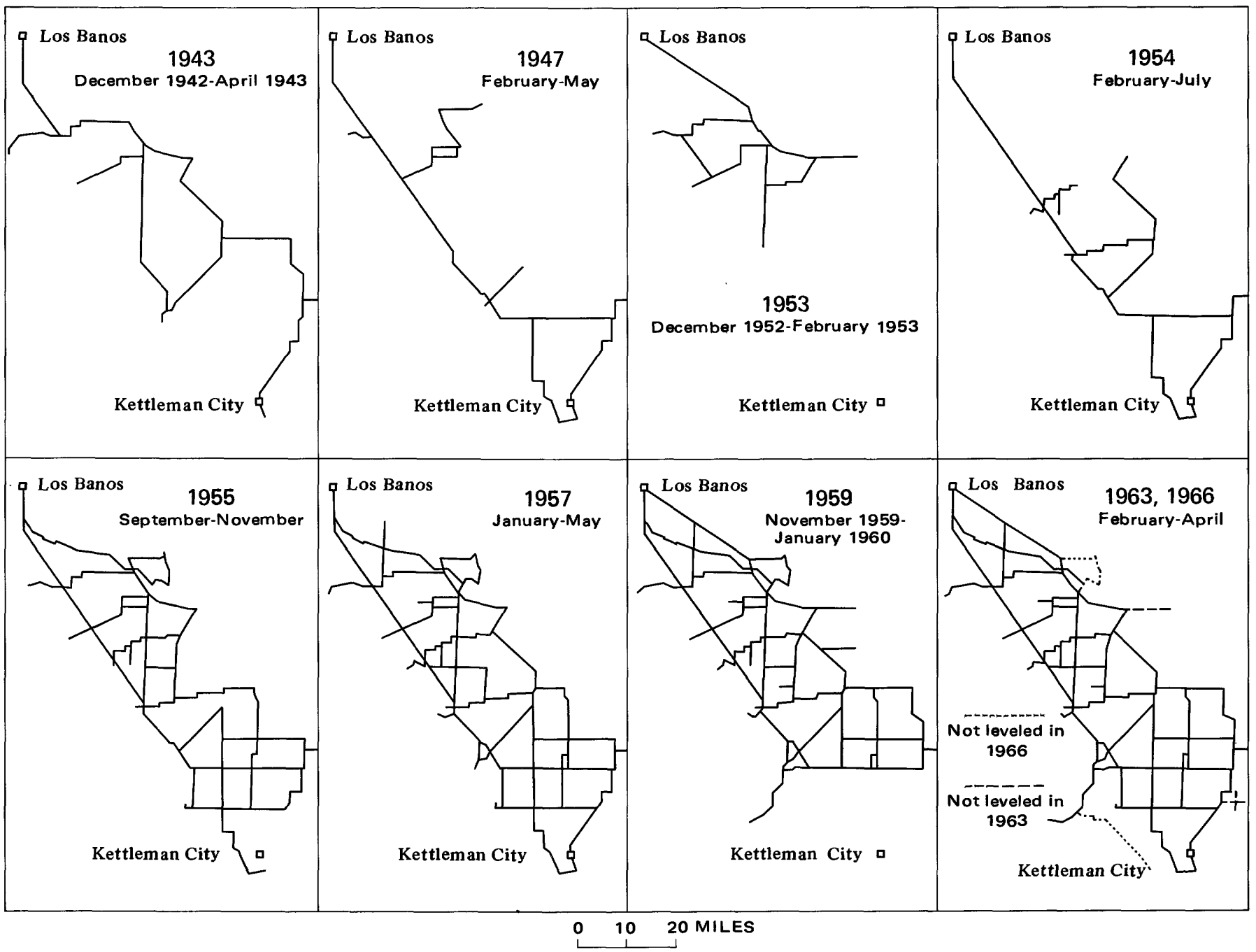

FIGURE 3.-Extent and times of principal leveling by the U.S. Coast and Geodetic Survey.

ment in the mountains is minor compared to the settlement of areas of active land subsidence. Even the stable bench marks may undergo changes in altitude due to tectonic movement or to mass movements such as soil creep. Evidence presented in the next section suggests that some of the bench marks in the mountains may have been uplifted tectonically about $0.1 \mathrm{ft} \mathrm{yr}^{-1}$ (fig. 4). Even outside control brought into the area may be complicated by natural or man-induced subsidence of tidal-gage reference bench marks.

The rate of subsidence due to artesian-head decline varies with both time and place. The times of most active subsidence are associated with the times of maximum head decline, or maximum rates of head decline, of the lower zone, which commonly are in March and June-September. During the times of maximum applied stress, 0.001-0.004 foot of subsidence occurs each day throughout most of the area. The best time to level the
Los Banos-Kettleman City area is between October and February because during this period the potentiometric levels are rising or are declining slowly from the winter high water levels. If leveling must be scheduled during the times of most rapid subsidence, it may be advisable to level those areas of most intense subsidence by second-order, rather than by first-order, methods. Less time is needed for second-order leveling; therefore, the cumulative error caused by subsidence between times of leveling ties to stable bench marks will be less.

\section{CHANGES IN THE ALTITUDE OF THE LAND. SURFACE}

In addition to subsidence due to the withdrawal of ground water, changes in land-surface altitude in the study area are caused by tectonic movements, withdrawal of petroleum, and application of irrigation water to dry clayey alluvial-fan deposits. 


\section{TECTONIC MOVEMENTS}

Pronounced uplift and subsidence caused by tectonic forces have occurred in the study area during the Late Quaternary. These movements are continuing, but are small in rate and are hard to discern from changes in the altitude caused by man's activities.

Both the Diablo Range and the west edge of the San Joaquin Valley have been subject to intermittent uplift which culminated in the Coast Range orogeny in the Pleistocene Epoch. The Coast Range orogeny was preceded by several periods of uplift (Taliaferro, 1943, p. 151-158), one or more of which resulted in the deposition of the Tulare Formation of Pliocene and Pleistocene age. The orogeny resulted in the monoclinal and anticlinal folds that form the foothill belt east of the main Diablo Range (Bull, 1964b, p. 93). Remnants of the Tulare Formation capping the foothills and the folding of the Pleistocene Corcoran Clay Member of the Tulare Formation to $45^{\circ}$ (Carpenter, 1965) attest to the magnitude of the uplift.

In the San Joaquin Valley, the western parts of the Corcoran were raised several hundred feet relative to the Corcoran east of the trough of the valley. The Corcoran and associated sediments have been folded gently throughout much of the area. The structure on the top of the Corcoran is described in detail by Miller, Green, and Davis (1971, fig. 11).

Uplift of the mountains has continued since the formation of the foothill belt to at least 3,000 years ago. Detailed studies of stream terraces and segmented alluvial fans (Bull, 1964b) show that the uplift was intermittent both in time and place and that the zone of maximum differential uplift generally was near the mountain front.

Large-scale subsidence of the San Joaquin Valley geosynclinal trough was concurrent with the deposition of several thousand feet of continental deposits after the ocean receded in the Pliocene Epoch. The rates of deposition were rapid. More than 900 feet of deposits accumulated in the Tulare Lake basin and elsewhere in the Los Banos-Kettleman City area in the 600,000 years (Janda, 1965) after the pluvial period associated with the Corcoran. Tulare Lake has remained a basin of interior drainage despite the rapid accumulation of fine-grained deposits (Davis and Green, 1962), and deep-seated subsidence and compaction have moved the top of the Corcoran to more than 700 feet below present sea level.

The facts that 900 feet of deposits have accumulated in parts of the Tulare Lake basin since Corcoran time and that it is still a basin of interior drainage indicate a large tectonic subsidence. The 600,000-year age for the deposits immediately above the Corcoran indicates a mean post-Corcoran depositional rate of about 1.5 feet per 1,000 years. Assuming the topographic features of the basin were the same as at present, the room for the 900 feet of deposits would be caused by subsidence of the bedrock floor under the basin and to a lesser extent by post-Corcoran compaction of the deposits between the bedrock floor and the top of the Corcoran.

Regional tectonic subsidence probably is continuing in the San Joaquin Valley, but the rate is so small that it cannot be differentiated from the rapid subsidence due to artesian-head decline.

Present-day tectonic movement of the mountain front was evaluated on the basis of leveling data. Two approaches were used-changes in the adjusted altitudes of individual bench marks were studied and changes in the unadjusted altitudes of pairs of bench marks were compared. Neither approach indicated net uplifts in excess of 0.1 foot during the history of leveling. Tectonic analysis is complicated by the fact that most, if not all, of the mountain-front area has been affected by minor amounts of subsidence due to man's activities.

Adjusted leveling results suggest minor net uplifts between certain periods of leveling at the mountain front of the Laguna Seca Hills, near the mountain front at Little Panoche Creek, and on Anticline Ridge. The amounts of apparent uplift are not listed because values of uplift of less than 0.1 foot may be within the amount of survey error in a subsidence region. These three sites are mentioned as areas of possible tectonic uplift on the basis of several lines of evidence, such as is presented in figures 4 and 5. Bench marks at all these sites show a net subsidence over the entire period of record, and net uplift is suggested only for one to three periods between levelings. Subsidence due to withdrawal of ground water is lowering the bench marks near the Laguna Seca Hills; subsidence due to application of water is affecting the areas near the mouth of Little Panoche Creek; and subsidence due to withdrawal of petroleum is affecting the Anticline Ridge area.

Adjusted leveling results for bench marks on lines crossing the mountain front indicate that net subsidence, in amounts of less than 1 foot, has occurred in the mountains near the mountain front at Warthan Canyon, Cantua Creek, Monocline Ridge, and Panoche Creek. With the exception of Warthan Canyon, these are areas of known tectonic uplift in the recent geologic past, and the present subsidence is most likely related to the withdrawal of ground water in the adjacent San Joaquin Valley.

$$
\text { Apparent Uplift Of Anticline Ridge, 1962-63 }
$$

Between March 1962 and March 1963, several bench marks on the crest of Anticline Ridge rose almost 0.1 
foot. The variation in the amount of altitude change along the highway crossing Anticline Ridge is shown in figure 4. The uplift was at a maximum at the crest and decreased toward the northeast and southwest flanks of the anticline. Bench marks in Pleasant Valley and the San Joaquin Valley subsided during the same period, although two bench marks adjacent to Anticline Ridge in Pleasant Valley underwent minor amounts of net uplift. The model used for movement occurring during a single year is one of "locked in" strain in an active structural element-strain that is released occasionally during short time periods.

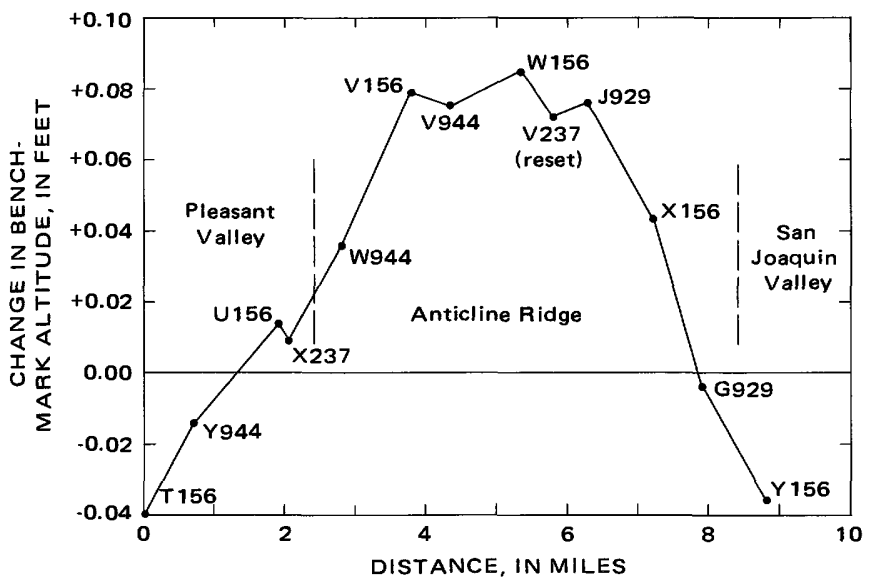

Figure 4.-Apparent net uplift of Anticline Ridge along State Highways 33 and 198, between March 1962 and March 1963

Bench-mark graphs showing changes in altitude in Pleasant Valley, Anticline Ridge, and the west edge of the San Joaquin Valley are shown in figure 5. All three graphs show a net subsidence for the period of record, but the graphs for bench marks Y156 and T156 do not show a decrease in the subsidence rate for the 1962-63 period. Therefore, the marked reversal in trend shown by $\mathrm{W}-156$ and four other bench marks on the crest of the anticline is not the result of the 1963 leveling being in

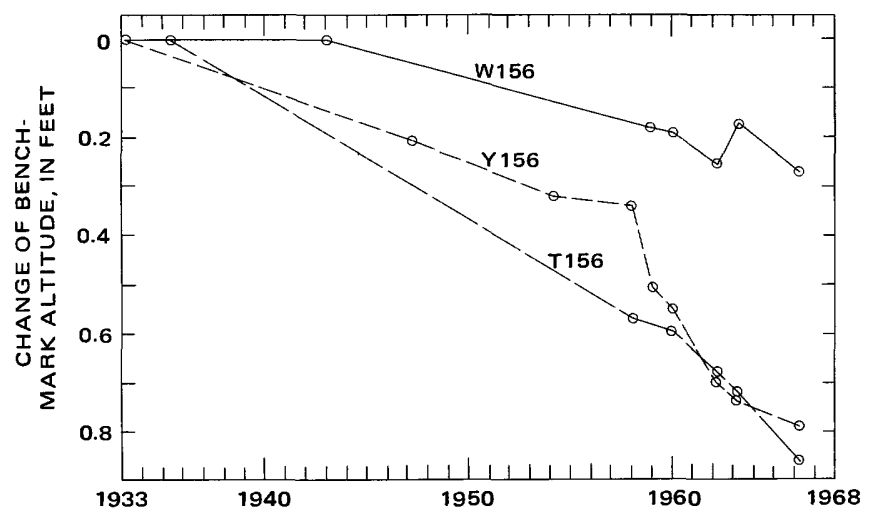

FIGURE 5.-Change in altitude of bench marks in Pleasant Valley (T156), Anticline Ridge (W156), and the west edge of the San Joaquin Valley (Y156), 1933-66. error by an amount equal to the net amount of uplift. The graphs also indicate that the amount of measured surface uplift is less than the true amount of tectonic uplift because of continuing long-term compaction.

\section{SUBSIDENCE DUE TO WITHDRAWAL OF PETROLEUM}

Some areas of intense land subsidence are associated with withdrawal of petroleum (Poland and Davis, 1969). Many oil and gas fields are adjacent to the Los Banos-Kettleman City area, but, of the large fields, only the 11-mile-long Helm field occurs entirely within the study area. The location and extent of the areas of petroleum production are shown in figure 6 .

The amounts of subsidence due to withdrawal of petroleum appear to be minor, but are difficult to differentiate from the subsidence due to withdrawal of water that occurs within or adjacent to the oil-producing areas. Bench mark W156, in the Coalinga oil field, subsided 0.26 foot between 1943 and 1962 (fig. 5). Part of the subsidence of bench marks east of bench mark W156 may be the result of withdrawal of ground water by wells tapping the Tulare and Etchegoin Formations in the adjacent San Joaquin Valley. Bench mark W156, however, is situated on the Jacalitos Formation, which is stratigraphically below the formations tapped for ground water. Because the bench mark is within the Coalinga oil field, it is presumed that most of the net subsidence is the result of extraction of petroleum.

$$
\text { NEAR-SURFACE SUBSIDENCE }
$$

The extent and magnitude of near-surface subsidence in the Los Banos-Kettleman City area are exceeded only by the subsidence due to artesian-head decline. Near-surface subsidence is the result of application of water to clayey moisture-deficient alluvial-fan deposits. Because compaction due to wetting occurs above the water table, it is independent of the subsidence due to artesian-head decline. As of 1964, near-surface subsidence had occurred in about 90 square miles or about 6 percent of the Los Banos-Kettleman City area (fig. 9). An additional 30-40 square miles, mainly upslope from the areas of known near-surface subsidence, probably would subside if irrigated. The upslope and middle parts of the small fans susceptible to this type of subsidence have about the same magnitude of potential subsidence, but the amount of subsidence generally decreases from the middle to the lower parts of the fans.

More than 500 square miles of the study area was subject to prehistoric near-surface subsidence resulting from intermittent streamflow on the large alluvial fans of streams that head in the main Diablo Range (Bull, 1972).

Near-surface subsidence characteristically varies markedly within short distances; it has destroyed or damaged ditches, canals, roads, pipelines, electric- 


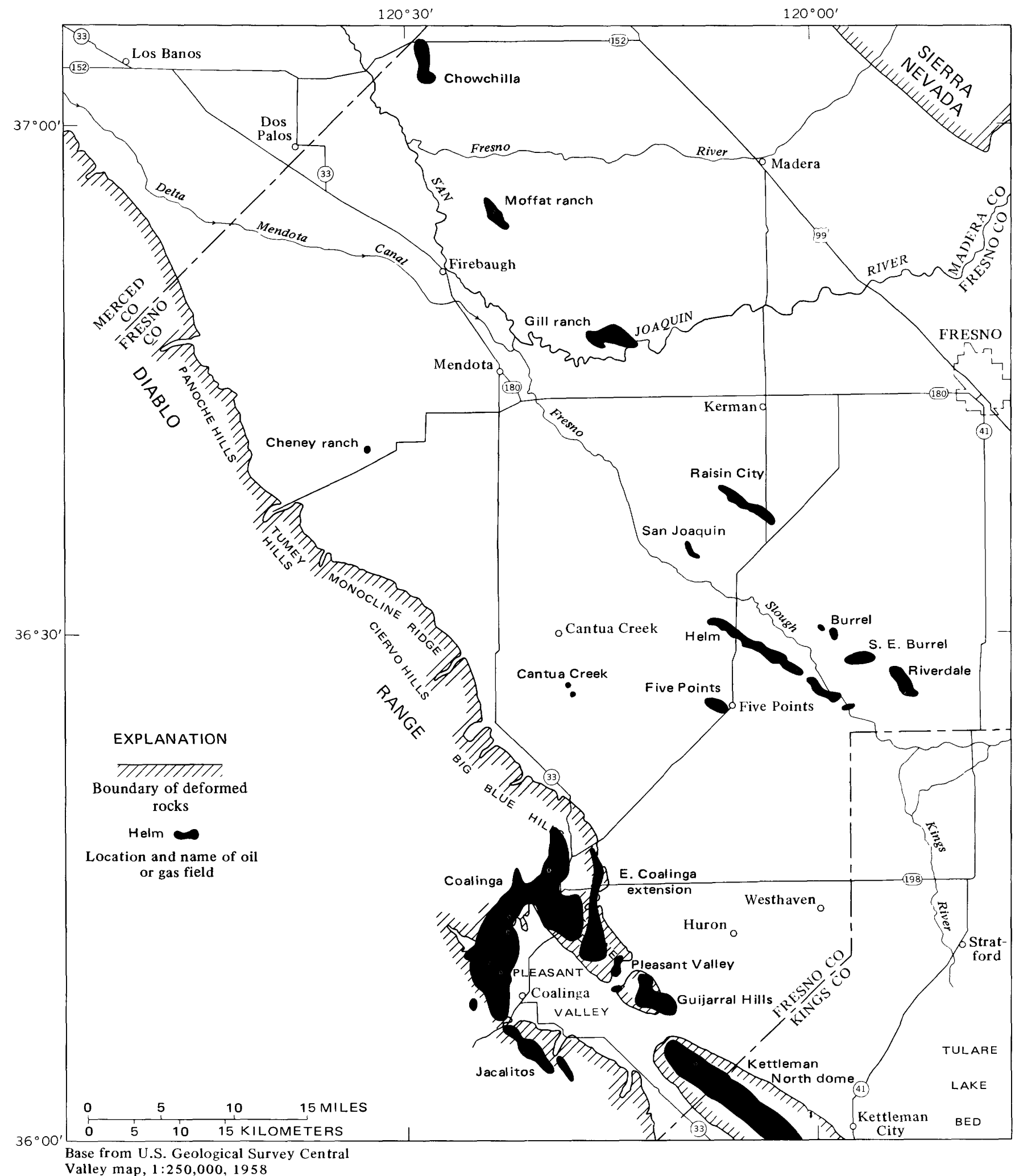

Figure 6.-Location of oil and gas fields in western Fresno County. (From California Division of Oil and Gas, 1960).

transmission towers, and buildings and has made the $\mid$ within small areas. The rate of subsidence is as much as irrigation of crops difficult. Subsidence of 3-5 feet is 0.25 foot per day and is controlled partly by the rate at common, and 10-15 feet of subsidence has occurred which the water front advances through the deposits. 
Subsidence cracks-which are typical of this type of subsidence-are vertical fissures that may or may not have offset of the bedding on opposite sides of the crack.

Near-surface subsidence results chiefly from the compaction of deposits by an overburden load as the clay bond supporting the deposits is weakened by water percolating through the deposits for the first time since burial. Two requirements are necessary for compaction due to wetting to occur: first, that after much of the water has been removed from the deposits by evapotranspiration, the moisture-deficient state of the deposits be maintained by absence of percolation of water from rainfall or streamflow as the deposits are buried to progressively greater depths; second, that the deposits have enough clay so as to undergo a decrease in compressive strength when they are wetted for the first time after burial. Most of the known compaction due to wetting has occurred in the upper 200 feet of deposits.

The amount of subsidence is dependent mainly on the overburden load, natural moisture conditions, and the amount and type of clay in the deposits. Test-plot data show that the compaction due to wetting varies directly with amount of overburden load under uniform gross lithologic and moisture conditions (Bull, 1964a, p. 48).

The type, amount, and moisture condition of clay influence the amount of subsidence. The predominant clay mineral in the subsiding fans is montmorillonite (Meade, 1967, fig. 14), which is stronger, at a given moisture content, than other clay minerals (Trask and Close, 1958).

Small fans (derived from the foothill belt of the Diablo Range) that are susceptible to subsidence usually have higher clay contents than nonsubsiding fans of the same size. The clay is derived from the marine sedimentary rocks of the Diablo Range. Soft clay-rich rocks predominate in the drainage basins of subsiding fans; there, they underlie an average estimated 67 percent of the area as compared to an average 38 percent for the drainage basins of nonsubsiding fans.

Fan deposits with low clay contents do not have enough dry strength to preserve voids supported by a sparse clay binder as the overburden load increases naturally; moreover, deposits with high clay contents do not compact much because the clay, even when wetted, partly supports the voids and because the clay swells. Maximum compaction due to wetting occurs at intermediate clay contents (Bull, 1964a).

Detailed studies of near-surface subsidence, the deposits that compact when wetted, and the source areas of the deposits have been made by Bull (1964a), and prehistoric near-surface subsidence is described by Bull (1972). Other studies, in conjunction with the planning and construction of the San Luis Canal section of the California Aqueduct, have been made by the California
Department of Water Resources and the Bureau of Reclamation. As a result of these various studies, the deposits along the route of the San Luis Canal section of the California Aqueduct that were believed to be susceptible to compaction due to wetting were preconsolidated by ponding.

\section{SUBSIDENCE DUE TO WITHDRAWAL OF GROUND WATER}

About a third of the San Joaquin Valley is subsiding because of ground-water withdrawals. The three principal subsidence areas are between the towns of Los Banos and Kettleman City, Tulare and Wasco, and Arvin and Maricopa (fig. 7).

The extent and the magnitude of the subsidence as of 1962-65 are shown in figure 7 . The total area within the 1 -foot subsidence line is about 3,800 square miles. The Los Banos-Kettleman City area is not only the largest but is the most intense of the three subsidence areas - subsidence has exceeded 20 feet, as compared with a maximum of 12 feet for the Tulare-Wasco area, and 8 feet for the Arvin-Maricopa area. In general, the boundaries of the three areas coincide with the areas of pumpage from confined and semiconfined aquifer systems. Since 1955, the rate of subsidence has been accelerating in the vicinity of Hanford, between the Los Banos-Kettleman City and Tulare-Wasco areas. Post-1963 leveling indicates that the rate of subsidence has increased along the trough of the valley for 20 miles north of Mendota and that much of this area has subsided more than 1 foot.

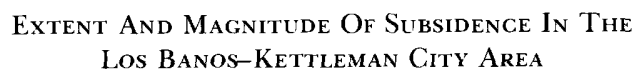

The two periods of topographic mapping and the many relevelings of bench marks in the area permit assessment of the changes of the extent, magnitude, and rate of subsidence. Many subsidence maps have been made, but only the most pertinent maps are included in this report.

The extent and magnitude of the early subsidence in the area are shown in figure 8 , which was compiled by subtracting the 1943-59 subsidence from the 1920-28 to 1959 subsidence. The area of intense subsidence west of Mendota was mapped topographically in 1920, and about three-fourths of the area within the 2 -foot subsidence line of figure 8 was mapped in $1920-21$. The 2 -foot subsidence line is close to, and parallels most of, the south, east, and north boundaries of the area irrigated with ground water as of 1937-42 (Pt. 1, Bull and Miller, 1974, fig. 21). Along the west side of the irrigated area, the 2 -foot line is $2-6$ miles west of the boundary of land that was being irrigated in 1937-42.

In contrast to the 10 feet of subsidence that had occurred in the northern part of the area, little 


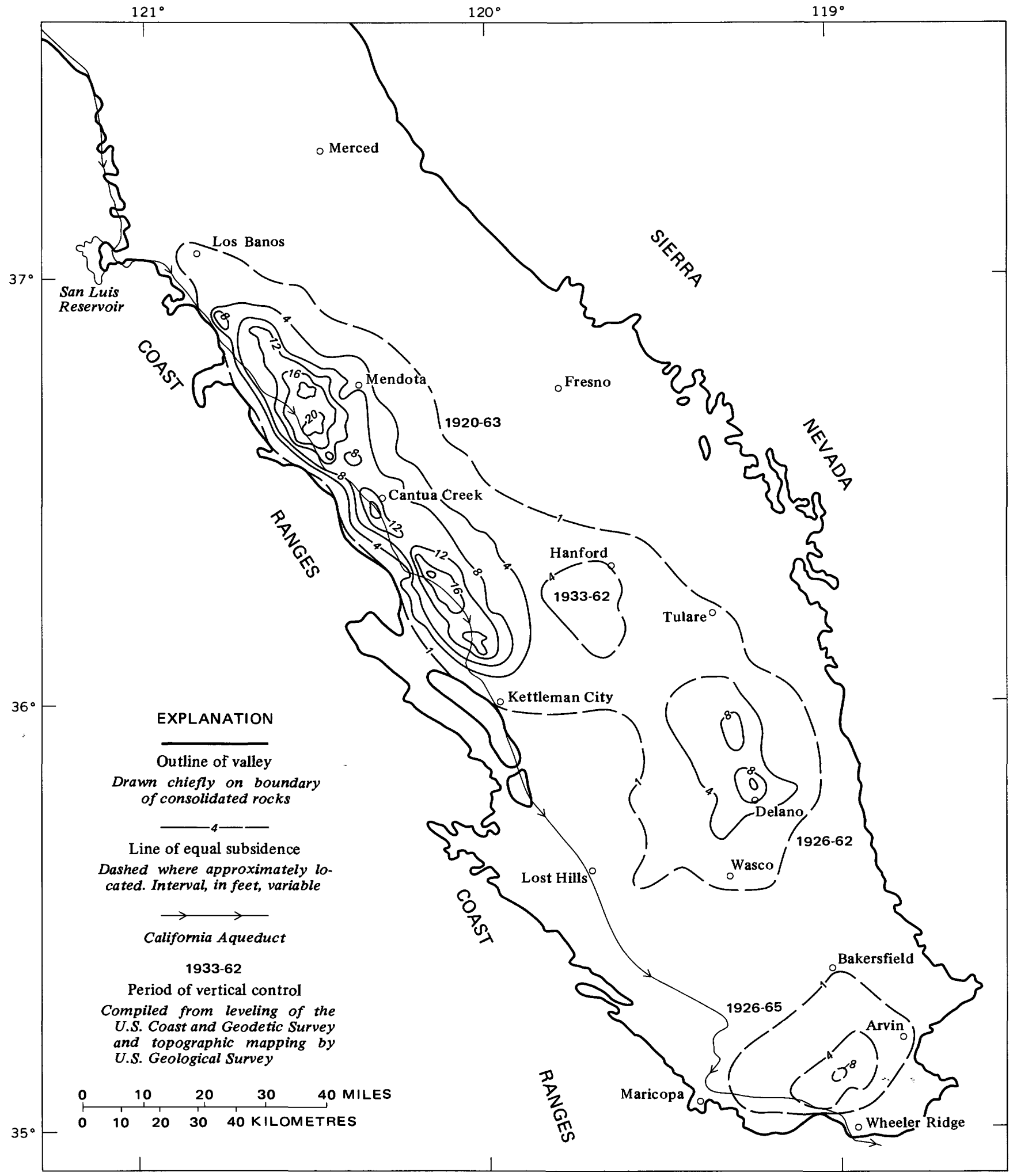

Figure 7.-Areas of major land subsidence in the San Joaquin Valley, as of about 1963. (From Poland and Evenson, 1966.$)$

subsidence had occurred as of 1943 in the southern part, | ence was minor. For example, bench mark PTS21S, where agricultural development was limited. Even in north of Westhaven, subsided only 1.2 feet between the largest area irrigated with ground water, subsid- 1923 and 1947. 
F12

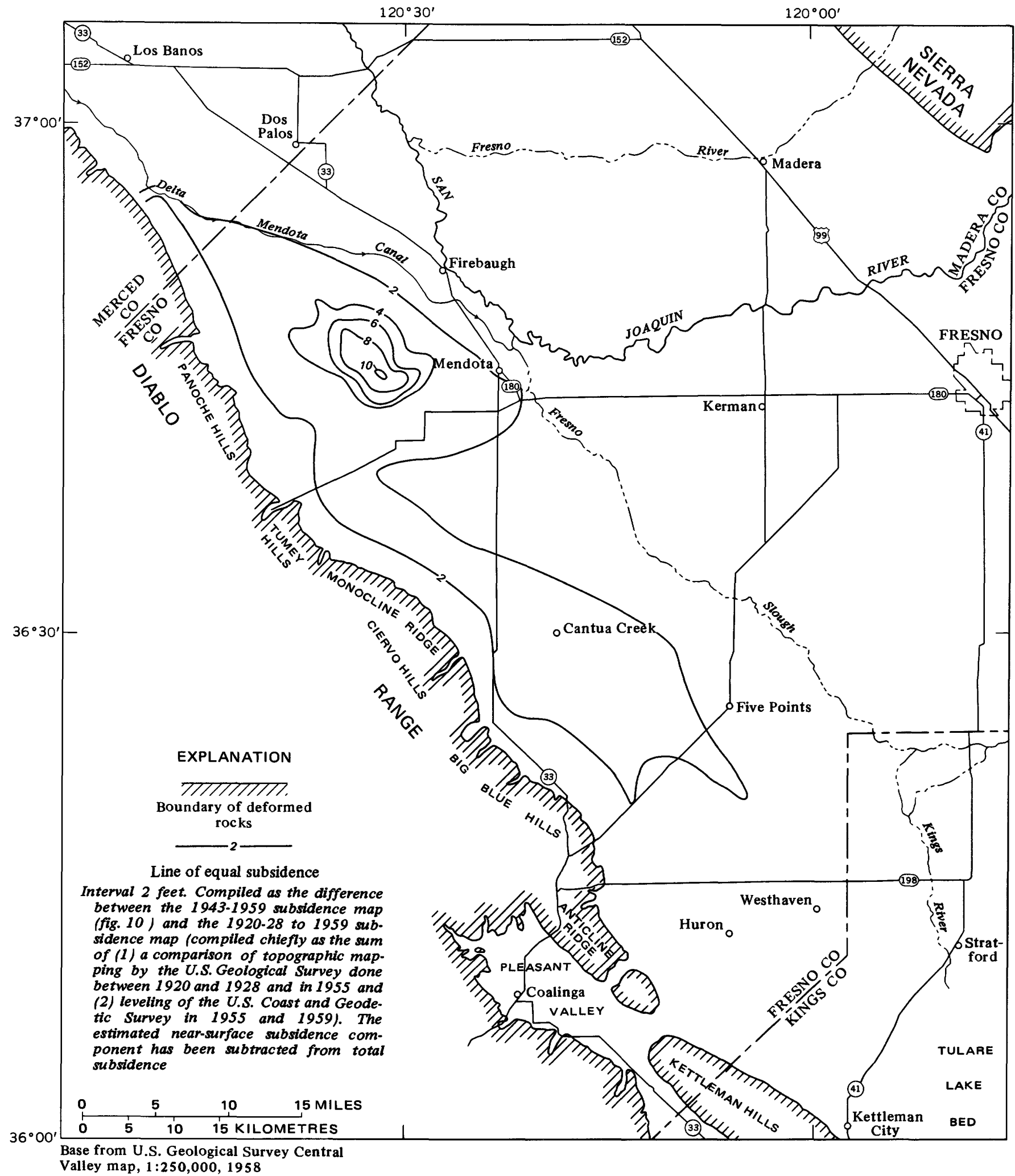

Figure 8.-Land subsidence due to artesian-head decline, 1920-28 to 1943.

The date 1920-28 was used for figure 8 and the The areas that were mapped prior to 1920 never have $1920-28$ to 1966 map because nearly all the areas of early subsidence were surveyed between these dates. subsided much, and the areas first mapped between 1928 and 1933 did not subside much until the middle 


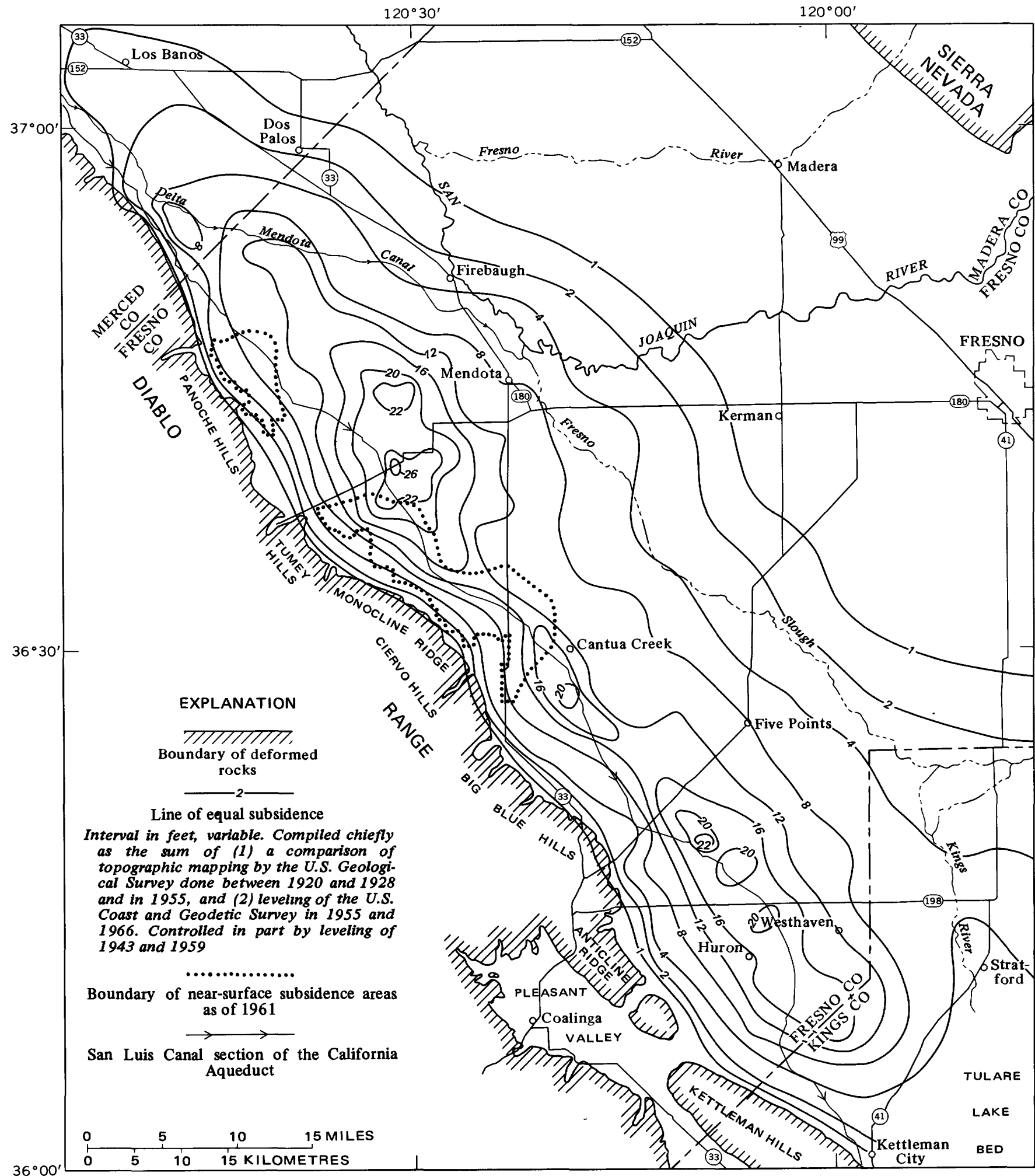

Base from U.S. Geological Survey Central

Valley map, $1: 250,000,1958$

F1GURE 9.-Land subsidence, $1920-28$ to 1966 .

1940's, as is indicated by the subsidence history of bench $\mid$ magnitude and extent of the long-term subsidence mark PTS21S.

within the Los Banos-Kettleman City area. The basic

The 1920-28 to 1966 subsidence map (fig. 9) shows the pattern of the lines of equal subsidence is an elongate 
oval. The area that has subsided more than 10 feet is 70 miles long, and the area within the 1-foot subsidence line exceeds 2,000 square miles. Maximum subsidence was about 26 feet at bench mark S661, southwest of Mendota. Within the main subsidence area, smaller elongate areas of locally intense subsidence occur. The southern part of the area had subsided as much as 22 feet by 1966, largely as a result of the accelerated compaction of deposits between the mid-1940's and the mid-1950's.

Near-surface subsidence occurred chiefly after 1950 and varied markedly within short distances. Local pockets of intense near-surface subsidence have not been included. Although some of the subsidence shown is the result of compaction due to wetting of alluvial-fan deposits, the amount is not large, and the trends of the lines of equal subsidence do not change upon entering or leaving areas of near-surface subsidence.

The San Luis Canal section of the California Aqueduct passes through the areas of most intense subsidence, but between the intense subsidence areas the canal passes through an area that had subsided only 4 feet as of 1966.

The 1943-59 map (fig. 10) shows only the subsidence due to artesian-head decline. The general pattern of subsidence is much the same as for the 1920-28 to 1966 map, but the maximum amounts of subsidence shown are 16 feet for both the northern and southern parts of the area. Because the dates of leveling control for this map are the same as the dates for the best available long-term water-level control, this map will be used later in this report to make a specific unit compaction map (fig. 56).

The near-surface subsidence component was estimated and removed from the differences in altitude for 14 bench marks used in the construction of the 1943-59 map. Several lines of evidence were used to estimate the amounts of near-surface subsidence. Some of the bench marks, although they are adjacent to areas of 2-10 feet of near-surface subsidence, probably have not been subjected to near-surface subsidence because they are in areas such as cotton gins, oil pumping stations, and farm buildings that are removed from the effects of irrigation water. By plotting subsidence profiles along level lines in near-surface subsidence areas, it was apparent that the protected bench marks had subsided less than nearby bench marks known to have been affected by near-surface subsidence. In some cases it was possible to draw a profile of the deeper seated subsidence due to artesian-head decline by using bench marks that were assumed not to have been affected by near-surface subsidence.

The history of irrigation within the area provided a second approach for estimating amounts of near-surface subsidence. Surveys by the California Department of Water Resources and the Bureau of Reclamation provided information on how long the land had been irrigated and on the type of crops grown. Test holes drilled by these agencies provided information about the depth of the wetted front near some of the bench marks known to have been affected by near-surface subsidence. This information was used to make estimates of the thickness of the dry fan deposits wetted since 1943 and the clay content of the deposits. The relation between (1) overburden load and compaction due to wetting and (2) the effect of clay content on compaction due to wetting (Bull, 1964a, fig. 27, p. 48-63) were applied to the data to make estimates of the near-surface subsidence component at those bench marks known to have settled as a result of compaction due to wetting.

With the establishment of the level-line network in 1955 , which was designed specifically to provide control on land subsidence, maps could be made that were based entirely on the results of leveling by the Coast and Geodetic Survey. The 1955-66 map (fig. 11) shows that more than 12 feet of subsidence occurred during these 11 years ( $13.1 \mathrm{ft}$ at bench mark S661). In the northern part of the area, the area of most intense subsidence had moved 8-10 miles south since the $1920-43$ period.

Because topographic remapping of the areas of most rapid subsidence was done in 1955, the 1955-66 subsidence map is the most useful map, at the time of the writing of this report, for correcting the 1955 map altitudes within the subsidence area.

The 1959-63 map (fig. 12) shows maximum subsidence was almost $4 \frac{1}{2}$ feet and a 54-mile-long area that had subsided more than 2.5 feet. In general, the area in the vicinity of the Delta-Mendota Canal subsided less than 1 foot, indicating a deceleration of subsidence rate from prior years. The 0.5 -foot subsidence line extended half way between Mendota and Kerman, and north of the Kings River in the vicinity of Highway 41, indicating an acceleration of subsidence in the eastern part of the area when compared with the 1957-59 map (not included in this report).

The subsidence during the next 3 -year period is shown in figure 13. Although the same time interval occurred between the 1959-63 and 1963-66 periods of bench-mark leveling, the amounts of subsidence in the 1963-66 period were substantially less than during the 1959-63 period. Maximum subsidence was only 3 feet, and the area having more than 2.5 feet of subsidence, instead of being a continuous 54-mile-long area, consisted of four isolated areas. The maximum subsidence was near the town of Cantua Creek in the central part of the study area, instead of being southwest of Mendota as in previous years. The subsidence rate 


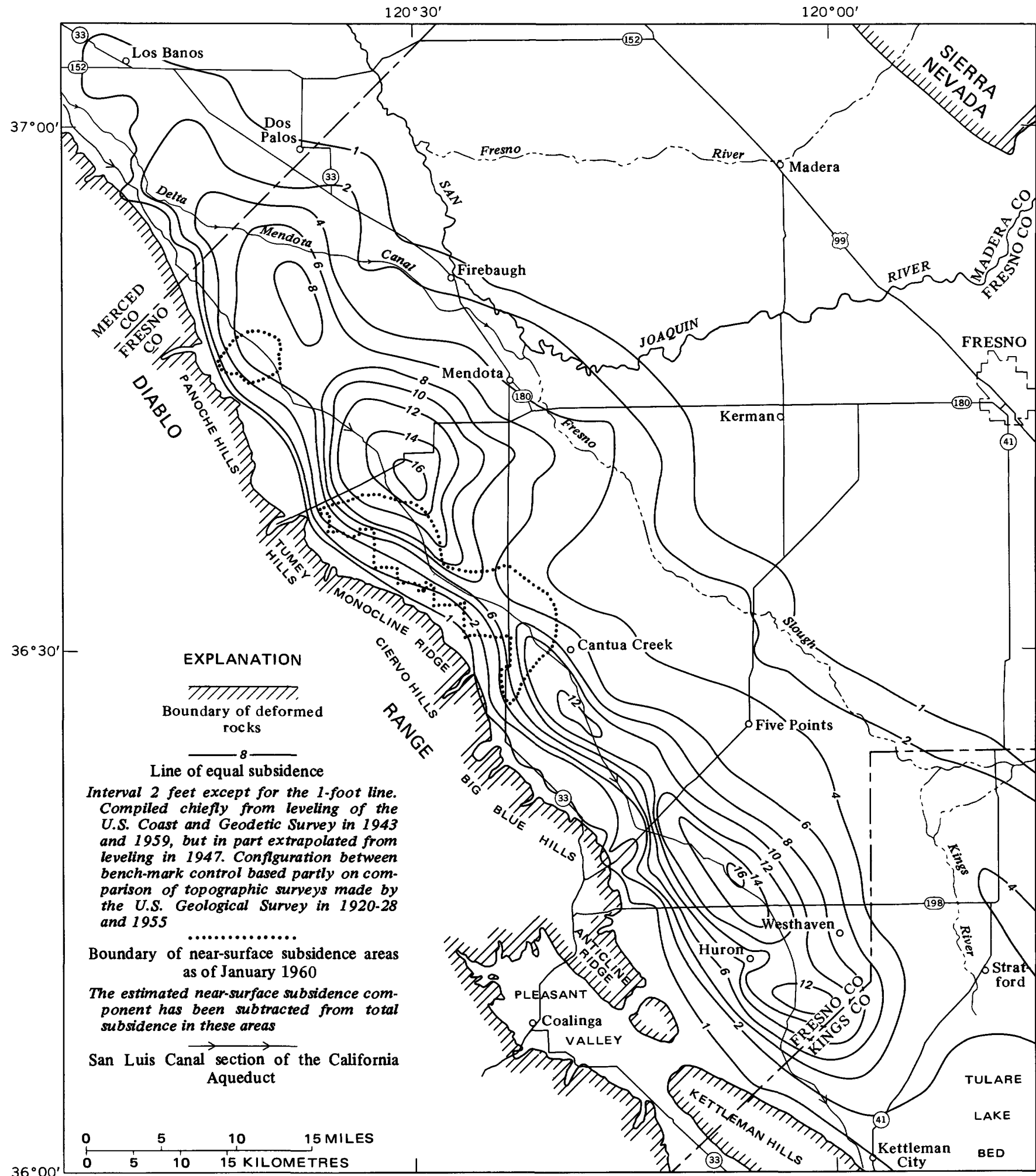

Base from U.S. Geological Survey Central

Valley map, $1: 250,000,1958$

Figure 10.-Land subsidence due to artesian-head decline, 1943-59.

remained the same northeast of Mendota, but decreased $\mid$ surface-water imports (Pt. 3, Bull and Poland, 1974, fig. markedly from the 1959-63 rate in the vicinity of the 49 ).

Kings River, owing to the greater availability of Additional leveling was done during the winter of 


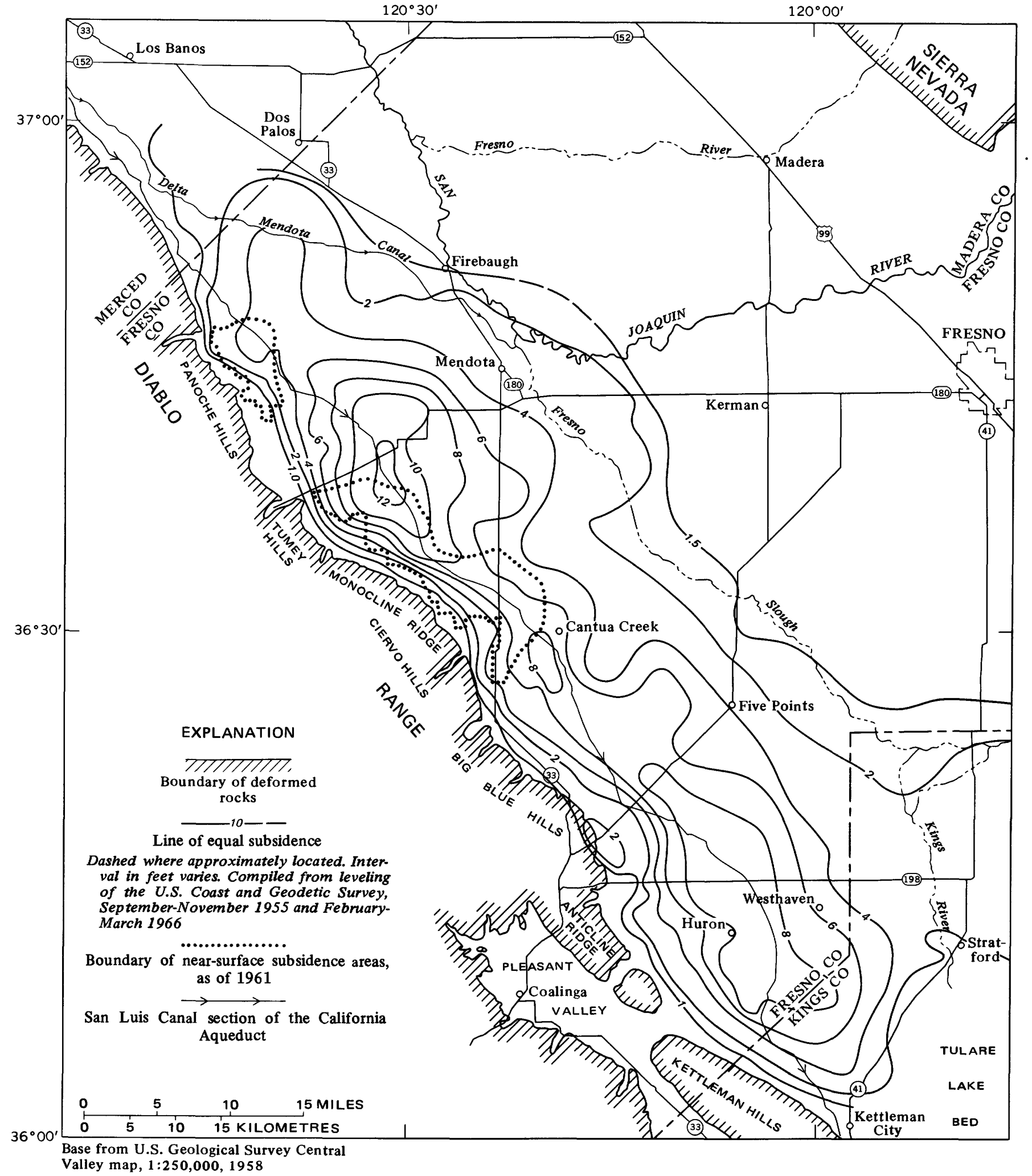

Figure 11.-Land subsidence, 1955-66. 


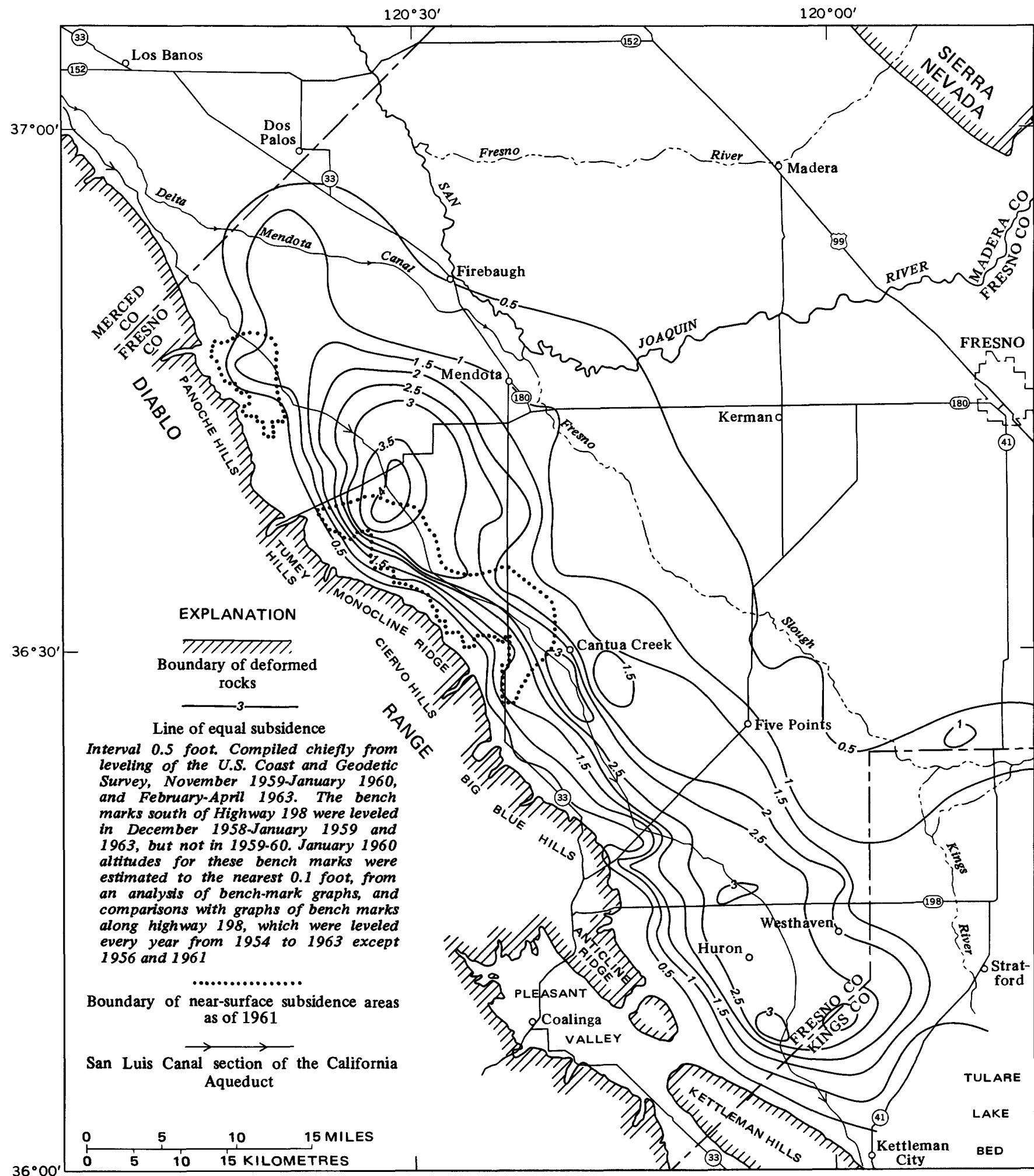




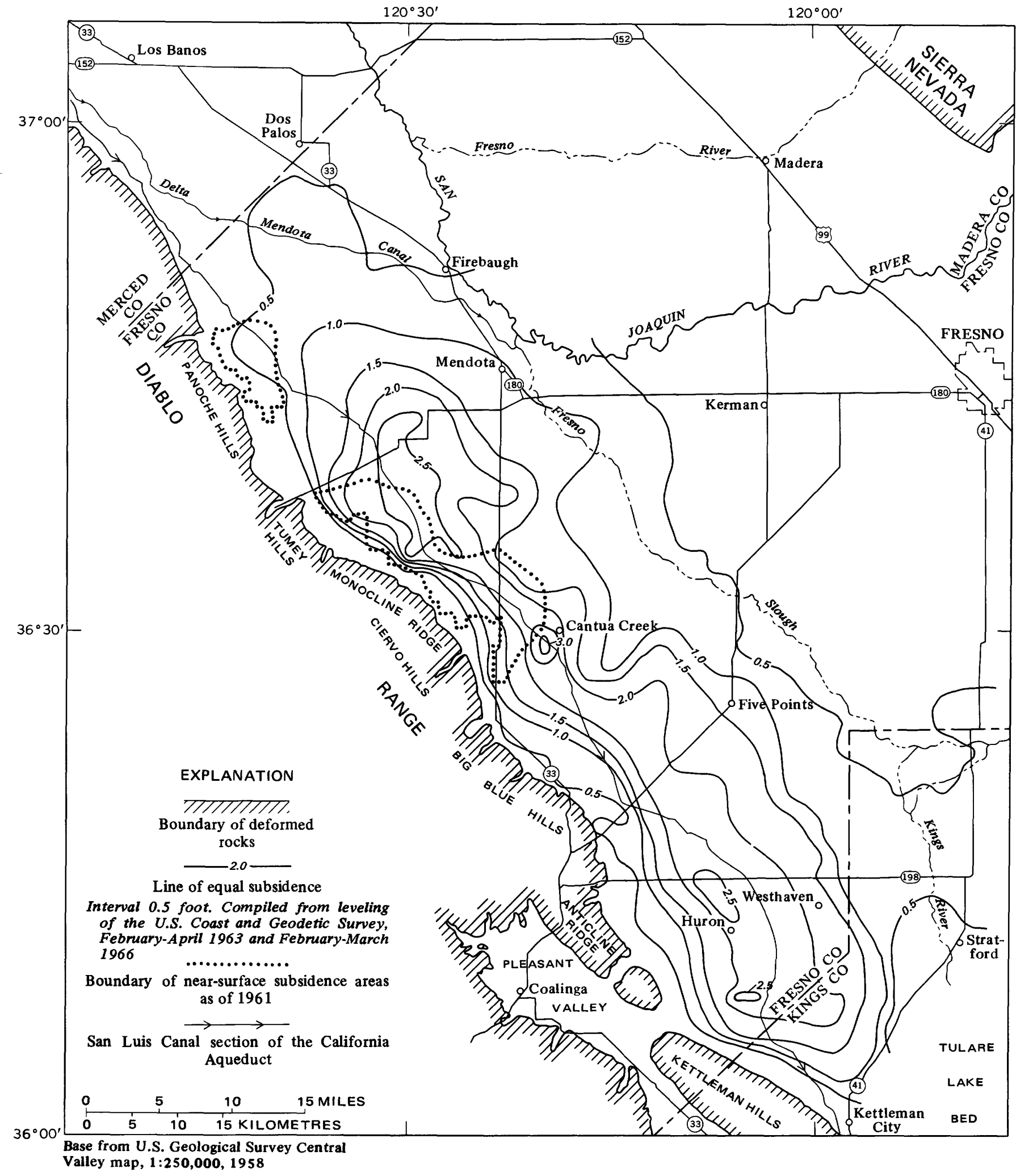

Figure 13.-Land subsidence, 1963-66.

1968-69, when bench marks along the completed San a small part of the Los Banos-Kettleman City area. The Luis Canal were leveled with the rest of the network. graph of distribution of subsidence intensity (fig. 14) is

The areas of most intense subsidence constitute only $\mid$ based on the 1920-28 to 1966 subsidence map and 


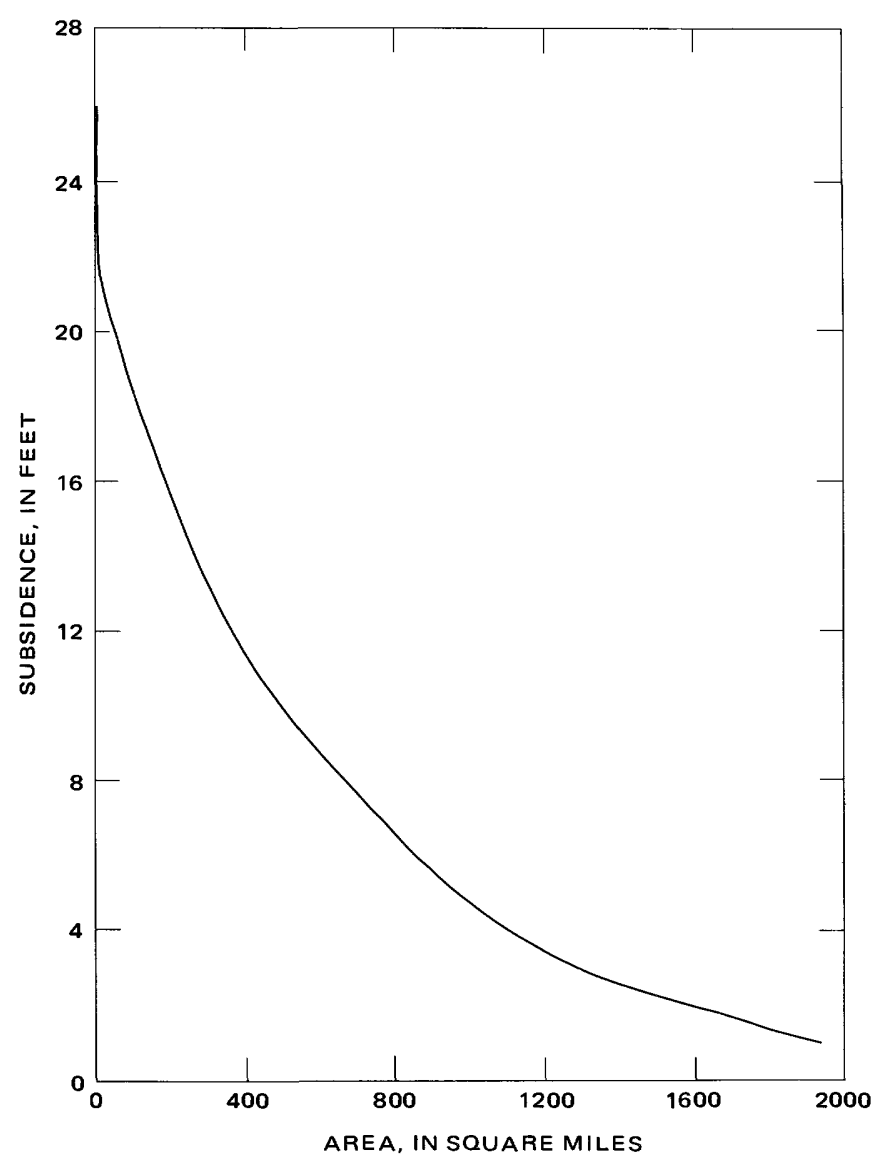

Figure 14.-Distribution of intensity of subsidence, 1920-28 to 1966.

includes areas that are northeast of the Los Banos -Kettleman City area as defined in figure 1. As of 1966, almost 2,000 square miles had subsided more than 1 foot, but only 50 square miles had subsided more than 20 feet.

The total volume of subsidence within the 1-foot subsidence line in the Los Banos-Kettleman City area between $1920-28$ and 1966 was $8,500,000$ acre-feet. This is the volume of water derived from compaction of the unconsolidated deposits and for the most part represents a permanent decrease in storage of the confined aquifer systems. However, because the compaction has occurred mostly in the fine-grained aquitards, usable storage in the aquifers has not been reduced appreciably.

\section{History Of Subsidence}

Past subsidence in an area as large as the Los Banos-Kettleman City area is likely to be highly variable. Subsidence graphs show a variety of trends, and subsidence profiles show that in some places the loci of maximum subsidence have migrated.

Nine graphs of cumulative subsidence are shown in figure 15. Bench marks in areas of ground-water pump- ing at the time that the bench mark was established do not show abrupt changes in the slopes of cumulative subsidence plots. Examples would be bench marks F678, H237 (reset), and the three bench marks at Mendota. Along the western and southern parts of the area, subsidence was minor until the agricultural expansion after World War II. For example, the plot of bench mark E220 southwest of Mendota shows little subsidence from 1935 to 1947 and then a large amount of subsidence distributed evenly over the two decades since that time. Marked changes in subsidence rates after 1947 also occurred at bench marks Q237, P692, and N692. At bench mark V805, steepening of the slope of the cumulative subsidence plot occurred after 1953. At bench mark W805, which is only 1 mile south of V805, the slope of the cumulative subsidence plot steepened gradually during the period of record.

The plot for bench mark L157 in the southeastern part of the area also shows the acceleration of the rate of subsidence after 1947. However, bench marks in this area show periods of little or no subsidence in 1956 and 1958 , which is in contrast with the pattern of the bench-mark histories in the rest of the area. The reasons for variation of the rate of subsidence at bench mark L157 are discussed in detail in Part 3 (Bull and Poland, 1974).

The amounts of subsidence can vary within short distances, as is shown by bench marks P692 and N692. These bench marks are only 1 mile apart, yet the total subsidence at N692 is about four times the $4 \frac{1 / 4}{4}$ feet of subsidence at $\mathrm{P} 692$.

Some bench-mark plots indicate a decreasing subsidence rate since 1950. The plot for N692 indicates a decreasing rate of subsidence, but the record at Mendota shows a gradually increasing rate of subsidence since 1919.

Two transverse subsidence profiles illustrate the histories of subsidence southwest of Mendota and Five Points. The locations of these profiles are shown in figure 1. Subsidence profile $A-A^{\prime}$ (fig. 16) extends from the edge of the foothills of the Diablo Range to Mendota, passing through the center of maximum subsidence shown in figure 9 . The series of profiles shows the different amounts of subsidence at seven times between 1943 and 1966. As much as 3 feet of subsidence occurred along the line of profile between 1935 and 1943 (fig. 8). From 1947 to 1957 the point of maximum subsidence migrated toward the southwest, and by 1966, 24 feet of subsidence had occurred at one point.

Subsidence profile $B-B^{\prime}$ (fig. 17) extends from Anticline Ridge through Five Points to Fresno Slough. The maximum subsidence in the 1943-66 period was 18 feet. The profiles are highly assymetric as compared with those shown in figure 16. The persistent steepness of the 


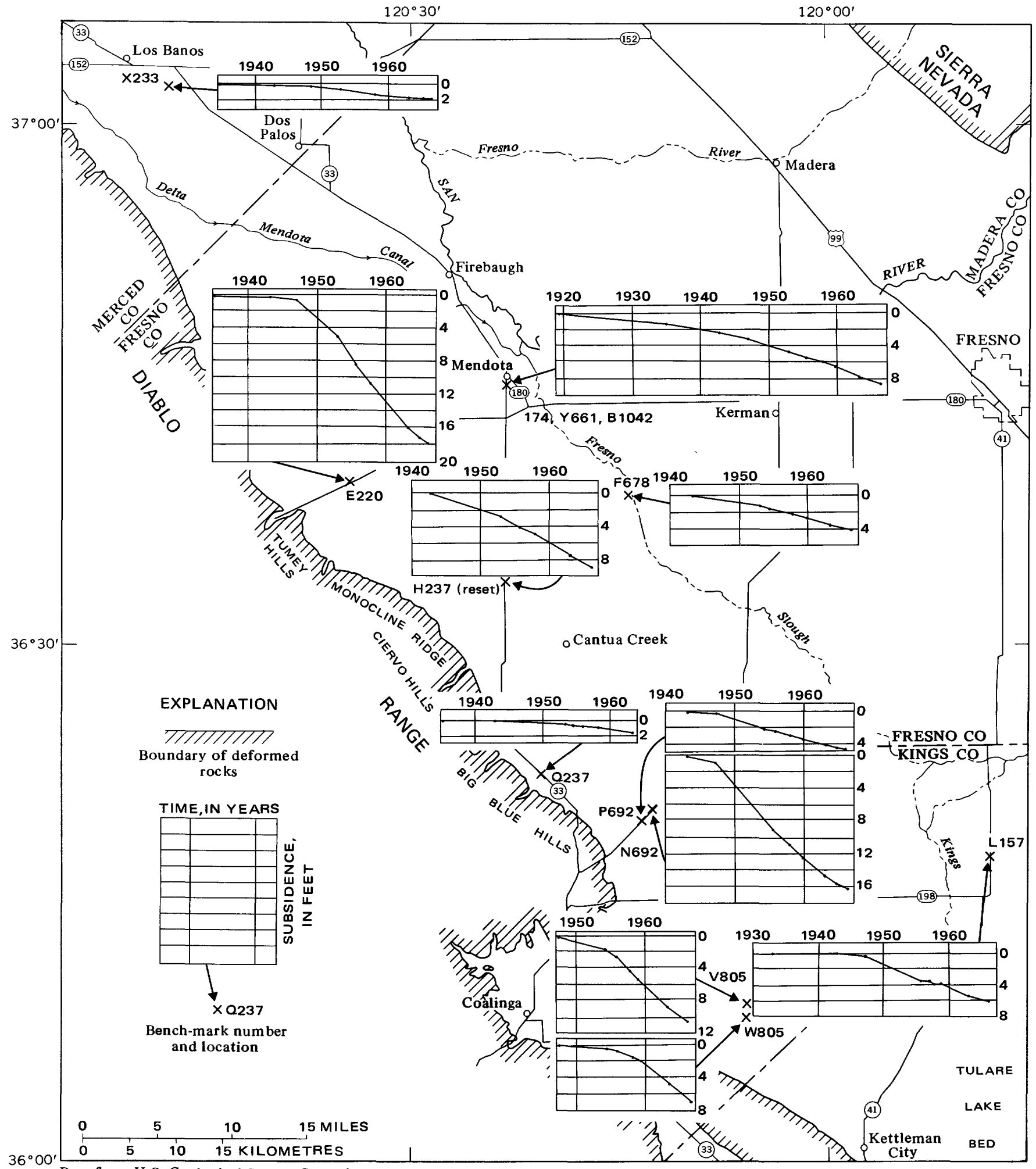

Base from U.S. Geological Survey Central Valley map, $1: 250,000.1958$ 


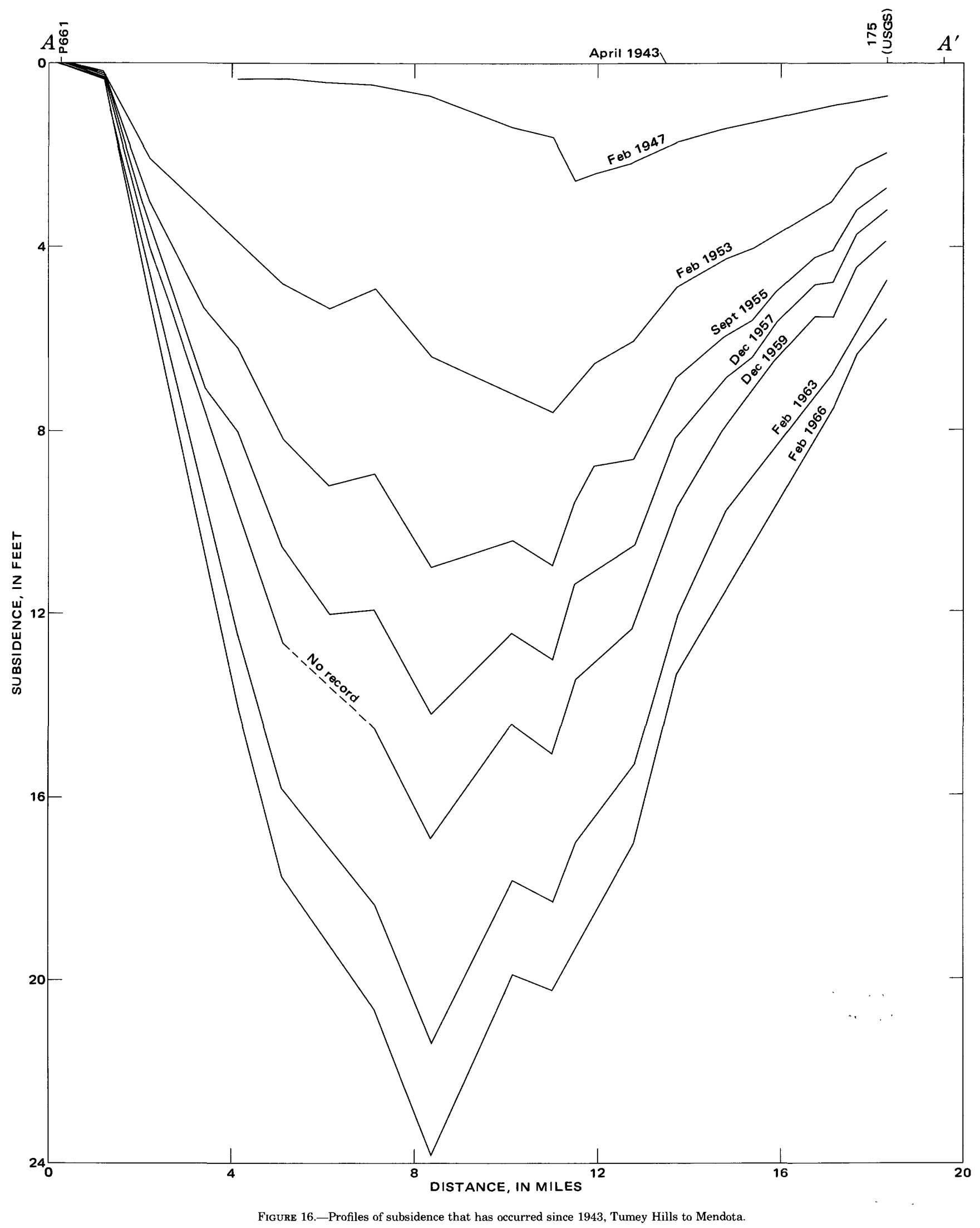




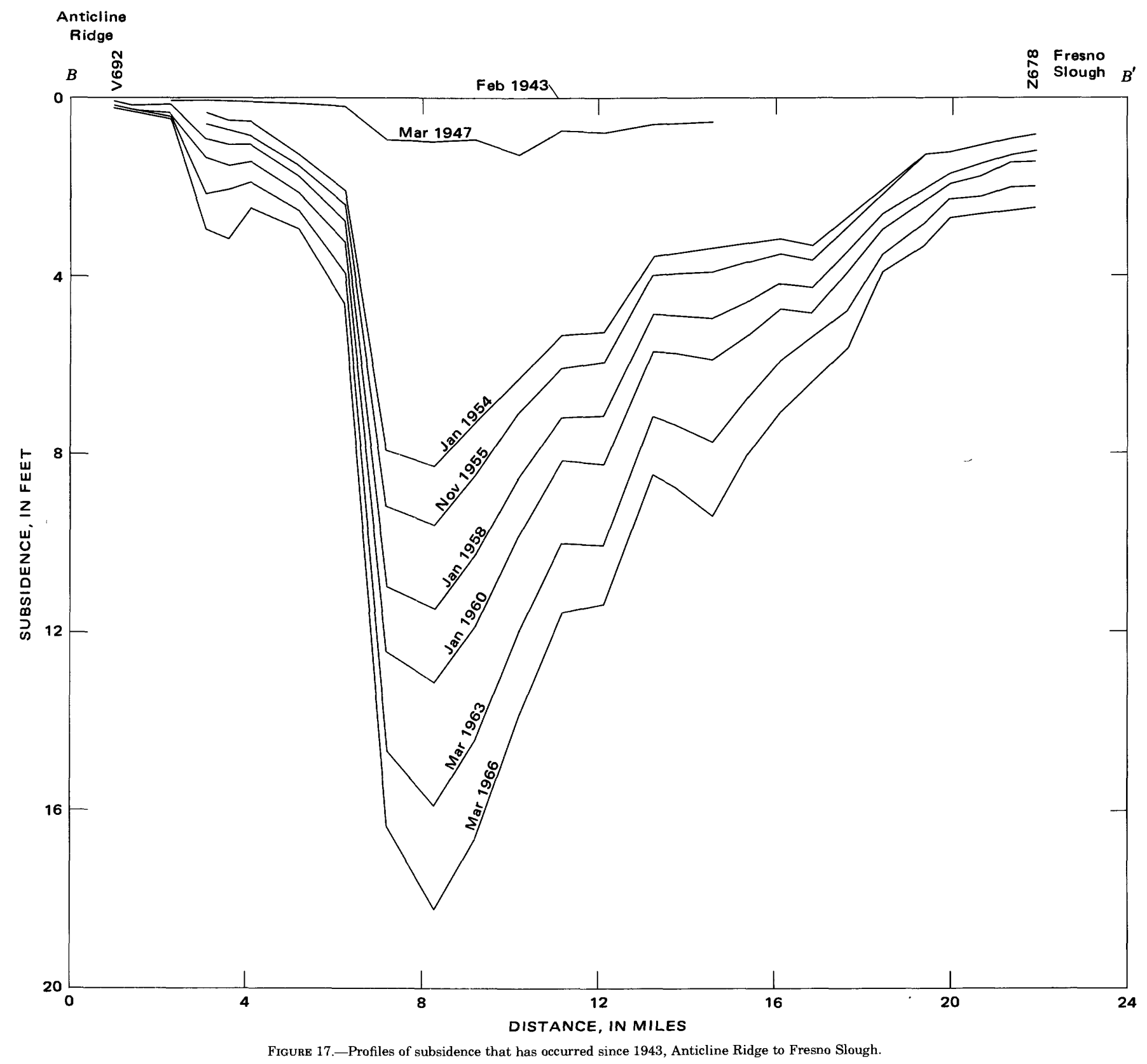

southwest side of the profiles is suggestive of a sudden change in the compaction characteristics of the sediments, or in the rate of withdrawal of ground water, or both.

Rate Of Subsidence

Changes in the slope of cumulative subsidence graphs, such as those shown in figure 15 , provide a general indication of changes in subsidence rate. In this section, the areal variations in subsidence rate will be discussed first, then the changes in subsidence rate, both regionally and at specific bench marks, will be discussed.

The trends of most lines of average yearly subsidence rate for the 1959-63 period (fig. 18) are similar to the trend of the lines of equal subsidence of the 1959-63 subsidence map (fig. 12). However, in the areas of widely spaced lines of equal subsidence, such as between Mendota and Five Points, the patterns of the lines of equal subsidence and the lines of equal subsidence rate are different.

Subsidence rate maps are useful in that they permit the designers of engineering structures, such as canals, to see at a glance the mean amount of subsidence that has occurred each year during a period of record. If the same units are used, rate maps are also useful in comparing the magnitude of subsidence occurring in differ- 


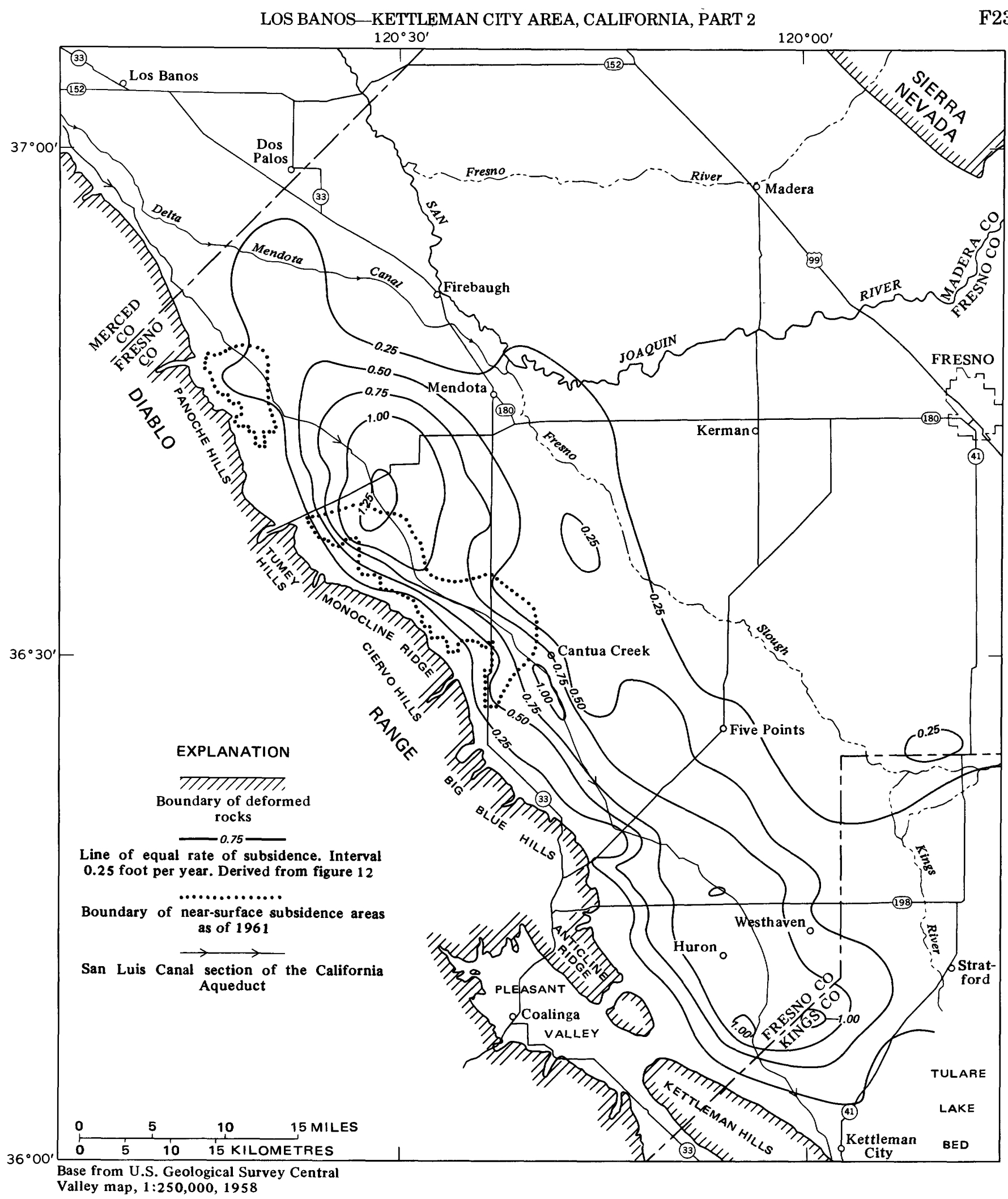

FIGURE 18.--Average yearly rate of subsidence, 1959-63.

ent areas. Figure 18 shows that the alinement of the $\mid$ and through one area that subsided between 1.25 and

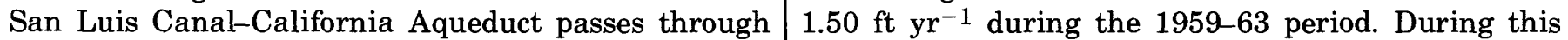

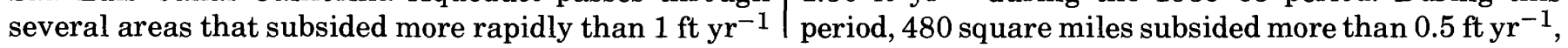




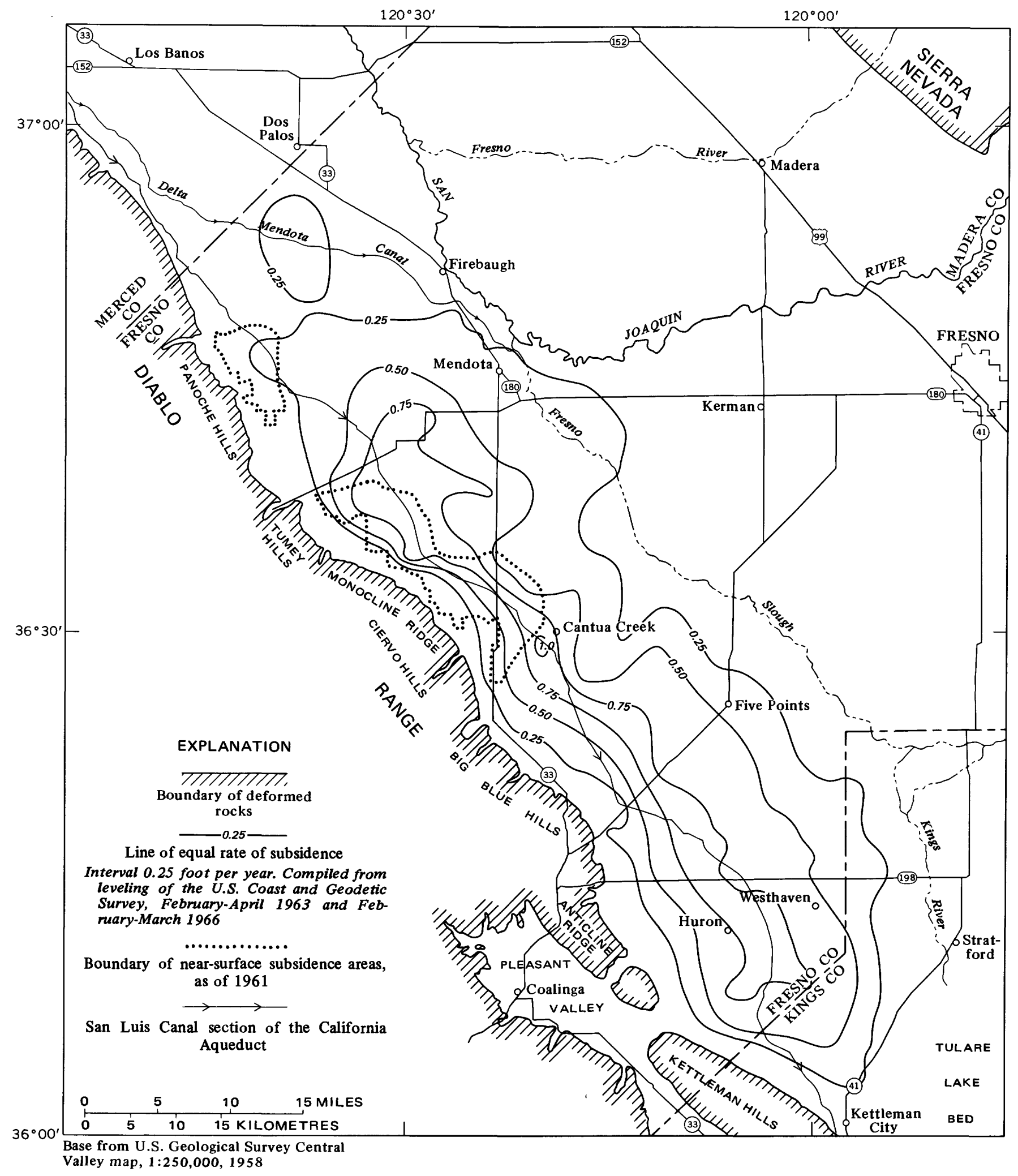

FigurE 19.-Average yearly rate of subsidence, 1963-66.

and 63 square miles subsided more than $1 \mathrm{ft} \mathrm{yr}^{-1}$.

The rate of subsidence during the most recent period of leveling, as of the time of writing of this paper, is shown in figure 19 . Only a small area subsided at a rate greater than $1.0 \mathrm{ft}^{-1} \mathrm{r}^{-1}$, and the area of most rapid subsidence shifted from southwest of Mendota to southwest of the town of Cantua Creek. Comparison of the 1959-63 and 1963-66 subsidence rate maps reveals 


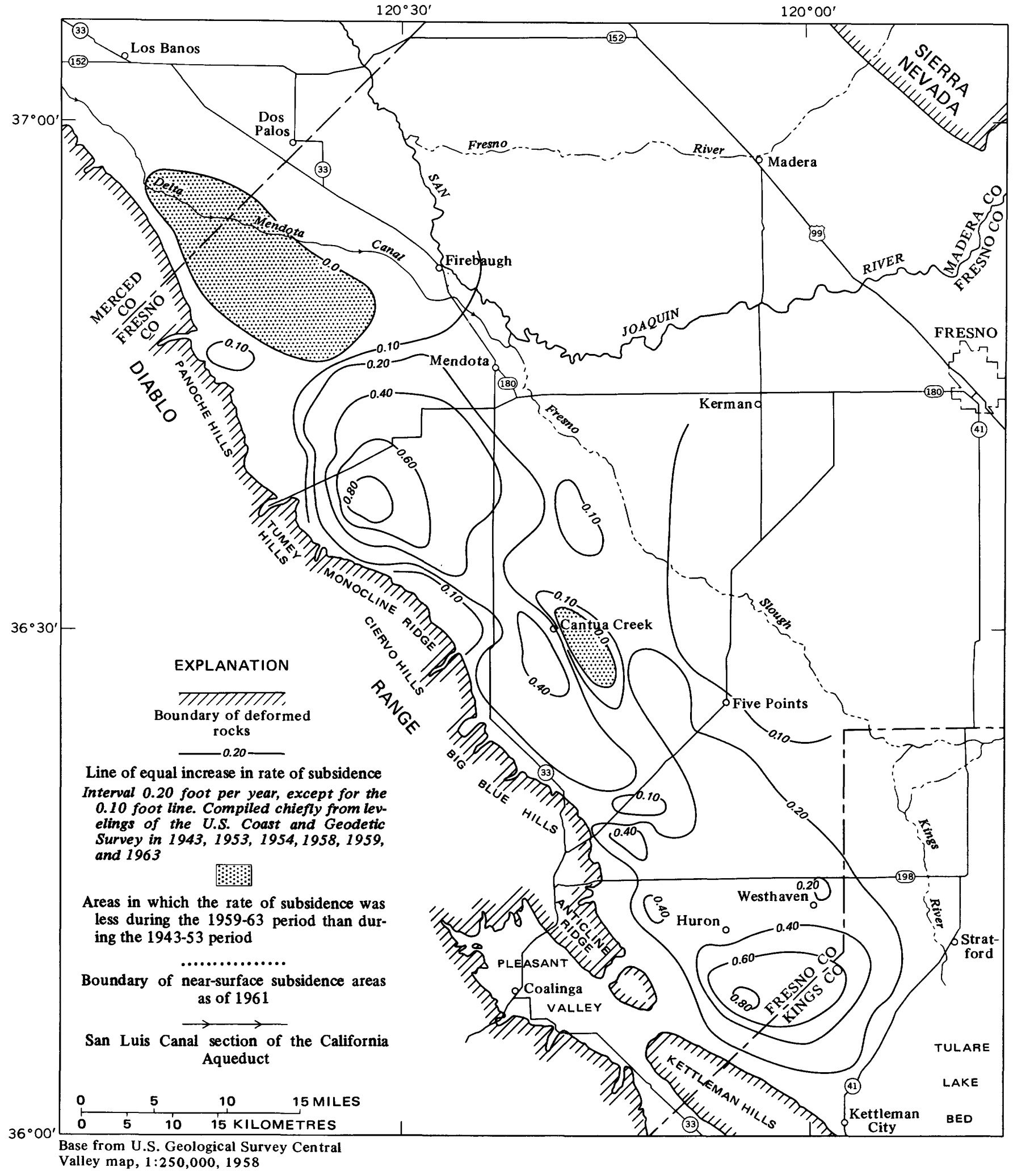

FIGURE 20.-Change in rate of subsidence between the 1943-53 and 1959-63 periods.

a general decrease in subsidence rate that is discussed determine the changes in rate between early and recent later (fig. 21).

A 1943-53 subsidence rate map (not included in this periods. Figure 20 shows that the rate of subsidence report) report) was compared with the 1959-63 rate map to area between the 1943-53 and 1959-63 periods. In most 


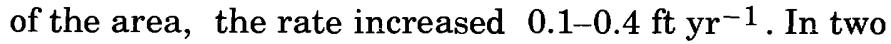
areas, one southwest of Mendota and the other southeast of Huron, the subsidence rate increased more than $0.8 \mathrm{ft} \mathrm{yr}^{-1}$. The rate decreased in two areas, a small area east of the town of Cantua Creek and a large area between Los Banos and Mendota.

The changes in the rate reflect changes in the many factors influencing increase in applied stress, compaction, and subsidence. The large area of decreased subsidence rate lies within the service area of the DeltaMendota Canal. Although some of the wells in the service area continued to be pumped after large-scale canal-water deliveries began in 1953, the net effect was for the artesian head to decline less rapidly than before, or to rise slightly, thereby causing a decrease in the compaction rate of the deposits. Some areas were already receiving surface water from other canals before the construction of the Delta-Mendota Canal. However, the area of decreased subsidence rate lies almost entirely within the area that has been receiving large amounts of surface water only since 1953. An area adjacent to the north end of the Panoche Hills has been receiving canal water since 1959 and shows little change from the subsidence rate that prevailed in the 1943-53 period. In contrast, the adjacent areas to the southeast that did not receive any surface water underwent a doubling of subsidence rate.

Most of the areas with a rate increase of more than

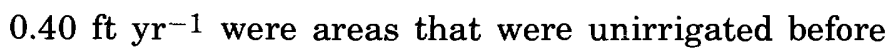
1940 but that were developed agriculturally with the aid of ground water between 1940 and 1950 (Pt. 1, Bull and Miller, 1974, fig. 22). In these areas, the change in rate is due largely to the fact that large manmade applied stresses persisted throughout the 1959-63 period, but were developed only during the latter part of the 1943-53 period.

Subsidence rates in much of the area irrigated with ground water throughout both periods increased from $0.1-0.4$ to $0.2-0.8 \mathrm{ft} \mathrm{yr}^{-1}$. The large increase in subsidence rates in areas already irrigated with ground water in 1943 probably is due to a combination of factors. Factors contributing to an increase in subsidence rate would include increases in the rates of artesianhead decline for the zones being pumped and increases in excess pore pressures in the aquitards.

Several aspects regarding the withdrawal of ground water were considered, but do not seem to explain fully the increased subsidence rate in those areas irrigated with ground water throughout both the 1943-53 and 1959-63 periods. The overall amount of ground water pumped within the area has not changed much since 1953 (Pt. 1, Bull and Miller, 1974, fig. 23). In general, the wells were perforated in the same intervals during both periods, which would indicate that the head de- cline was occurring in the same zones during both periods. An increase in the rate of head decline within the area would explain the increase in subsidence rate, but pumping levels have been declining at a progressively slower rate in much of the area.

The factor that accounts for the increased subsidence rates is increased excess pore pressures in the aquitards. Evidently, the head in the aquifers has been drawn down more rapidly than aquitard excess pore pressures could decay, and hence the differential between the head in the aquifers and average excess pore pressures in adjacent aquitards has increased. The rate of subsidence is a function of this head differential.

The change in subsidence rate between the two most recent periods of leveling of the bench-mark network is shown in figure 21. In contrast to the comparison shown in figure 20, subsidence rates during the 1963-66 period were less than during the 1959-63 period throughout most of the area. Within about 80 square miles in the northern part of the area, the subsidence rate had decreased more than $0.25 \mathrm{ft} \mathrm{yr}^{-1}$ between the $1959-63$ and 1963-66 periods. In the central and southern parts of the area, the subsidence rate decreased more than 0.25

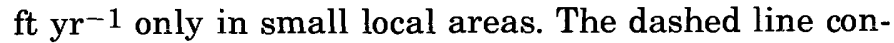
nects the outermost points of no change in subsidence rate between the two periods, but intersection of rate lines of the two maps show that isolated points of no change in rate occur within the dashed line. Some small areas of minor increase in subsidence rate in the southern part of the area were suggested by comparison of the two maps (figs. 18, 19), but in these areas the suggested

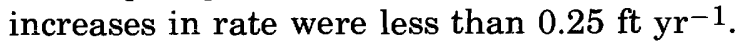

The contrast between the trend of subsidence rates in figures 20 and 21 is the result of a decrease in the rates of increase of stress being applied to the aquifer system, as indicated by decreasing rates of artesian-head decline (Pt. 1, Bull and Miller, 1974, fig. 45). Rates of artesian-head decline have decreased markedly in recent years and have been accompanied by slight to moderate decrease in subsidence rates. Some of the geologic reasons for the greater decrease in subsidence rate in the northern part of the area are discussed in the section "Geologic Factors Influencing Compaction of the Unconsolidated Deposits."

Bar graphs of subsidence rates for five bench marks (fig. 22) show the changes in subsidence rate better than the changes in slope of the cumulative subsidence graphs of figure 15. Both the amounts and patterns of changes of subsidence rate are highly variable in the different parts of the study area.

The record for bench mark 97.68 (USBR) shows increasing subsidence rates from 1937 to 1954 and decreasing rates since then. The marked reversal in the trend of subsidence rate coincided with the delivery of 


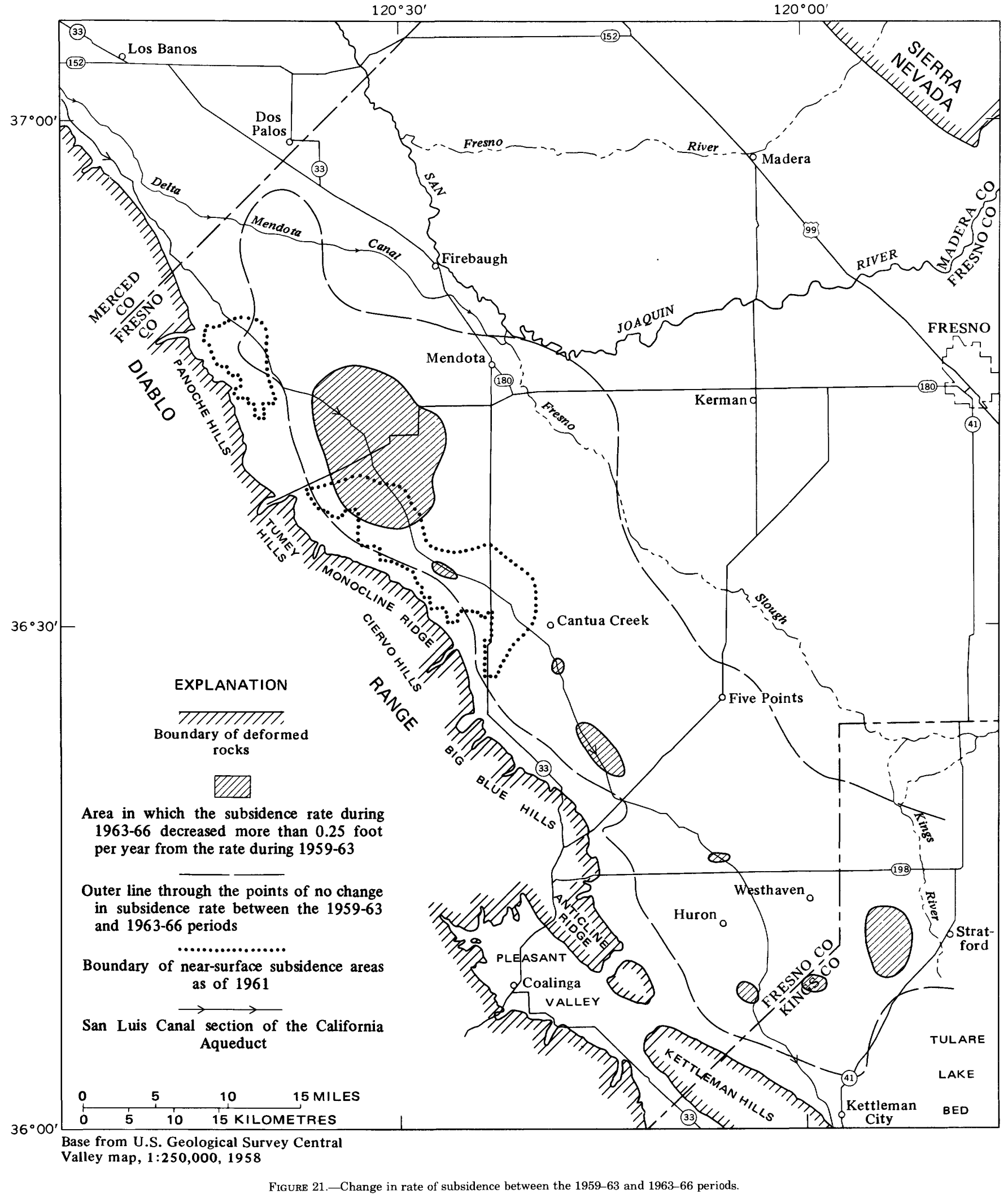

Delta-Mendota Canal water to the area. The dotted line $\mid$ of best fit because it is based on equal areas above and showing the interpolated general subsidence rate is an below the line. The post-1963 line is tentative, for postintegration of the bar-graph data. There is only one line 1966 data are necessary to complete the integration. 


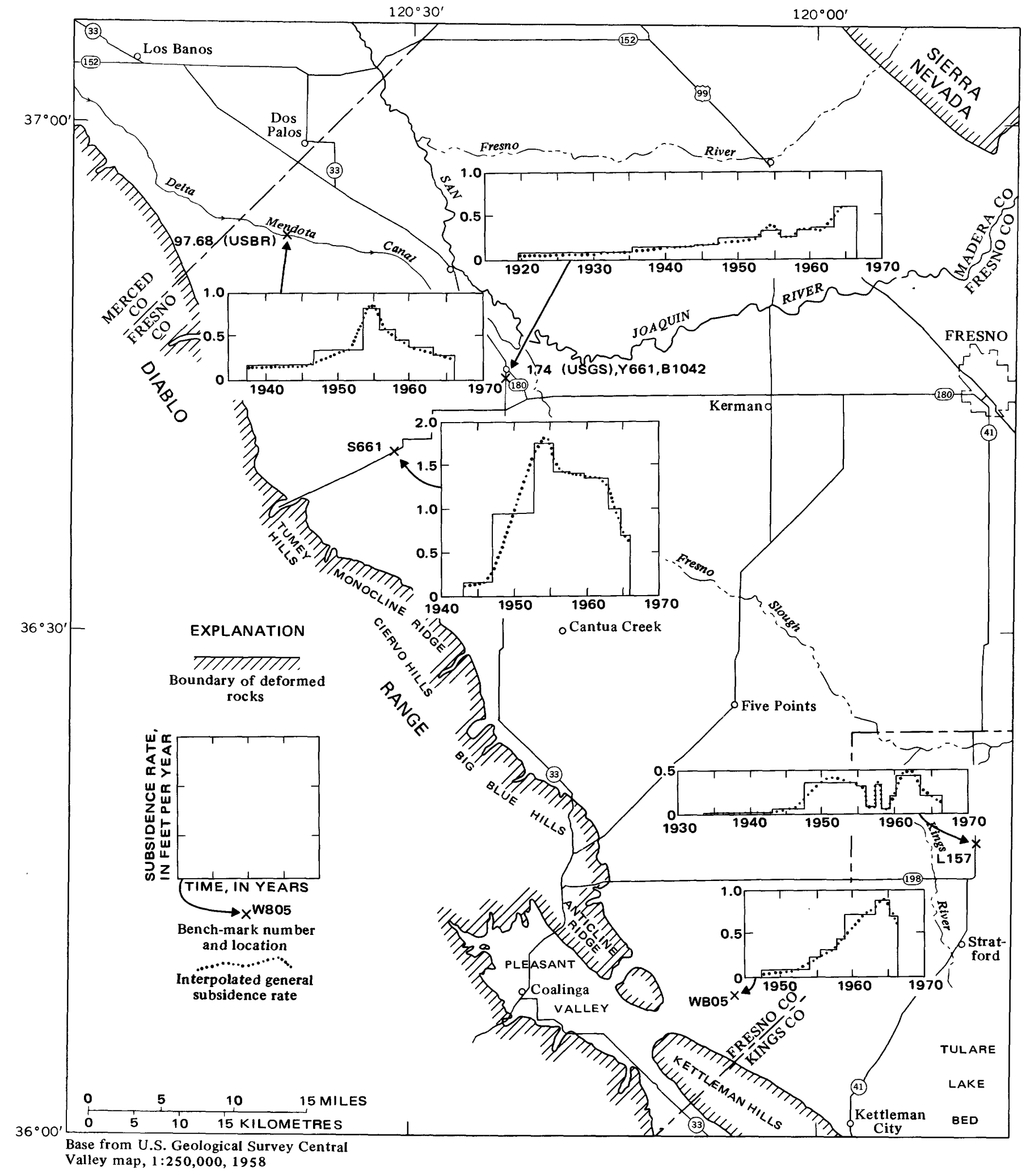

FIGURE 22-Histories of subsidence rates for selected bench marks

Subsidence rates have increased steadily since 1919 at Mendota. Some minor fluctuation of subsidence rate occurred during the middle 1950's, and the rate increased the most rapidly in the 1963-66 period.
Bench mark S661 has subsided more than any other bench mark in the San Joaquin Valley. The altitude of this bench mark declined 24 feet in the 23 years prior to 1966. The rate of subsidence has not been uniform, 
although, at first glance, the cumulative subsidence graph (Pt. 3, Bull and Poland, 1974, fig. 30) appears to have a fairly constant slope since 1947 . The subsidence rate increased rapidly between 1943 and 1953 as ground water was pumped in the vicinity for the first time. The interpolated general subsidence rate line indicates that the maximum rate of subsidence was in 1954 and was more than $1.8 \mathrm{ft} \mathrm{yr}^{-1}$. Since 1955 , subsidence rates have been decreasing, and by 1965 the rate was only $0.7 \mathrm{ft} \mathrm{yr}^{-1}$. Bench mark S661 is in the large area of recent decrease in subsidence rate (fig. 21). At this bench mark, the subsidence rate decreased $0.51 \mathrm{ft}$ $\mathrm{yr}^{-1}$ between the $1959-63$ and $1963-66$ periods.

The increased subsidence rates at bench mark W805, in the southern part of the area, also are associated with agricultural expansion since 1947 . In contrast with the record of S661, however, the rates do not define a peak until 1964 (fig. 22).

The record at bench mark L157, in the southeastern part of the area, shows three periods of little or no subsidence and two periods of subsidence rates of about $0.4 \mathrm{ft} \mathrm{yr}^{-1}$. Subsidence in this part of the area since 1955 is influenced by changing proportions of the sources of irrigation water, which include surface water from the Kings River and ground water from above and below the Corcoran.

\section{COMPACTION OF THE GROUND-WATER RESERVOIR}

In the preceding section, most of the subsidence in the Los Banos-Kettleman City area was attributed to excessive withdrawal of water from confined aquifer systems. This section describes the compaction of the ground-water reservoir and compares the amounts of compaction and subsidence.

The best information regarding the amounts, rates, and vertical distribution of compaction is obtained from specially drilled wells or unused irrigation wells that are equipped to measure shortening of the deposits between the land surface and a designated depth. A second source of information is provided by studies of wellcasing shortening and rupture that occur as a result of compaction.

\section{FIELD MEASUREMENTS OF COMPACTION}

TYPES OF COMPACTION GAGES USED

The methods of measuring compaction used by the Geological Survey have evolved from relatively simple to refined equipment that is adaptable to the problems encountered at individual locations. The basic type of recording compaction gage is shown diagrammatically in figure 23. A heavy weight is lowered to the bottom of the well on a $1 / 8$-inch cable. Where possible, the anchor weight is set below the casing bottom to measure the vertical shortening of the deposits rather than the concurrent shortening of the well casing. At the land sur-

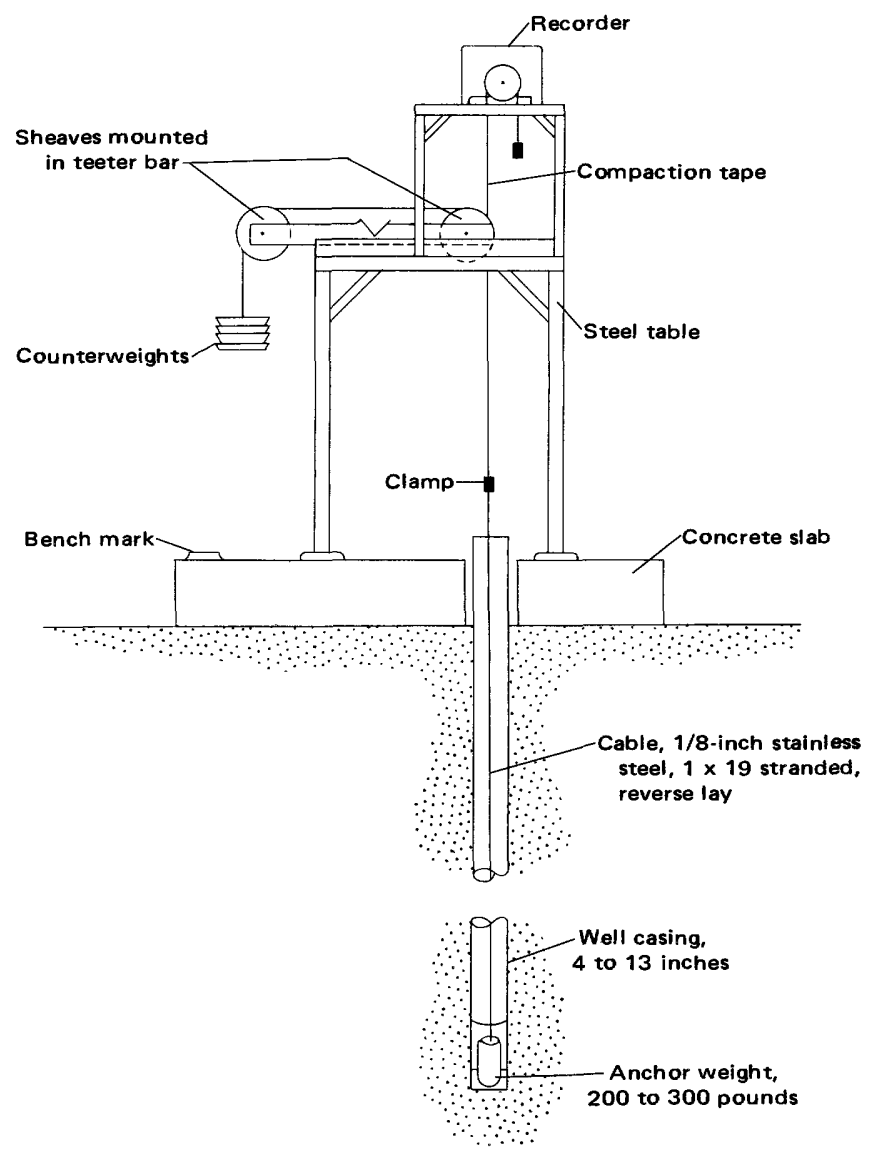

FiguRE 23.-Diagram of recording compaction gage.

face, the cable is passed over two ball-bearing sheaves and is counterweighted to keep it taut. The sheaves are mounted in a metal rack set on a 1-foot-thick concrete foundation that does not touch the well casing. A mechanically driven hydrographic recorder (Stevens, type F) set in the rack is connected to the $1 / 8$-inch cable with a small diameter cable that is clamped to the main cable and passes over the drive pulley of the recorder. As compaction occurs, the concrete slab and the recorder move downward relative to the cable clamp, because (ideally) the length of the cable remains constant as the thickness of the aquifer system decreases. The movement of the recorder relative to the small-diameter cable rotates the recorder pulley and chart drum, producing a graph of compaction at a scale of $1: 1$. The principal limitation upon the accuracy of the system is friction between the well casing and the down-hole cable.

Many improvements have been made since the first recorders were installed. In wells where the amount of friction between the casing and cable is small, an expanded-scale record is obtained directly in the field through the use of a second recorder linked to the first by an amplifying gear train. A 12- or 24-times expansion of the record is useful in observing the finer details 
of the compaction record, provides more accurate measurements of short-term compaction, and permits determination of the times of changes from recorded compaction to record expansion of the aquifer system.

Friction in the above-ground components of the system has been reduced to a negligible level by mounting the sheaves in a teeter bar. As compaction occurs, the teeter bar tilts on a knife-edge fulcrum, but the sheaves do not rotate. The sheaves rotate when the bar is leveled each time the recorder is serviced. Errors caused by seasonal swell due to changes in surface moisture conditions have been largely eliminated by the use of concrete and steel, instead of wood, in the tables and foundations. Changes due to seasonal soil swell have not been eliminated entirely, but can be measured when necessary.

Compaction of the enclosing deposits shortens and destroys well casings. Slip joints installed in some compaction-recorder wells apparently have been successful in preventing or delaying major casing damage.

The characteristics of the cable are of paramount importance. Even small unit changes in cable elongation due to fatigue or untwisting are significant if they affect much of the length of a 2,000-foot cable. Changes in the position of the top cable clamp due to these factors cannot be distinguished from changes due to compaction unless special measurements are made. The effect of temperature changes is not considered important, because below a depth of a few feet the temperature remains uniform.

The first cable used for compaction recorders in the study area consisted of $7 \times 7$ stranded $1 / 8$-inch galvanized steel, but corrosion caused failure of cables at several sites within a few months. This cable was replaced with stainless steel, plastic coated, $7 \times 7,1 / 8$-inch stranded cable, which resisted corrosion, but had more casingcable friction than the uncoated cable. Also, the cable tended to untwist as indicated by rotation of the counterweights. As of 1968, 1/8-inch, $1 \times 19$ stranded, uncoated, stainless steel, reverse-lay cable had been found the most desirable for compaction-recorder use. It resists corrosion, has low stretch and friction characteristics, and little tendency to untwist. The low tendency to untwist under load is due to the fact that the six strands about the center strand spiral in the opposite direction from the outer twelve strands.

A different type of compaction gage was installed in

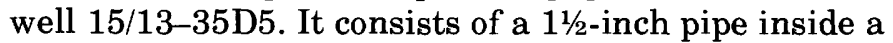
casing. The bottom of the $1 \frac{1}{2}$-inch pipe was set 7 feet below the bottom of the enclosing 4-inch casing. Changes in aquifer-system thickness are determined at monthly intervals by measuring the distance between the top of the 11/2-inch pipe and a steel frame bolted to a concrete foundation that encloses but does not touch the 4-inch casing. Wells 20/18-11Q2 and 16/15-34N4, at the Westhaven and Cantua sites, also operate as a compaction-pipe type of gage. (See description of the Westhaven site under section "Shortening of an OilWell Casing.")

The first compaction recorder was installed in September 1955 in well 19/17-35N1. The site was an unused irrigation well 2,030 feet deep, having 16-, 12-, and 9 -inch casing. The compaction record from this installation is shown in Part 3 (Bull and Poland, 1974, fig. 11).

Attempts to install compaction recorders in the three core holes drilled in 1957 were unsuccessful. As an experiment and an economy measure to eliminate casing costs, sidewall anchors were installed in core hole $12 / 12-16 \mathrm{H} 1$, which was uncased. The hole collapsed during installation of the equipment, even though it was filled with a special mud to inhibit caving. Later attempts to install compaction recorders in uncased holes 14/13-11D2 and 19/17-22J1, 2 used 1/4-inch iron tubing to protect the cables. These compaction recorders were unsuccessful because of excessive friction between the tubing and cable and because of corrosion and cementation.

By January 1968, 21 wells were providing information about compaction in the Los Banos-Kettleman City area. Groups of recorders with bottom-hole weights set at different depths are at 12/12-16H near Oro Loma, at 14/13-11D west of Mendota, at 16/15-34N near the town of Cantua Creek, and at 20/18-11Q near Westhaven. Twelve of the recorders operate in groups, and nine operate singly.

Descriptions of the compaction-recorder installations are summarized in table 1 , and their locations are shown in figure 1 . Where possible, the anchor was set below the casing bottom, and, in the unperforated wells, the anchors were set as much as 49 feet below the bottom of the casing. In most of the perforated wells, however, the anchor weight was set on sand in the casing; in most of these the sand was brought into the well as a result of development to observe water-level changes. Attempts to bail the sand from the casing usually resulted in a continuing influx of sand through the perforations. However, useful compaction records are obtained because the casings are shortened almost the same amount as the sediments that encase them and because the amounts of compaction that do not cause casing shortening cause measurable increased casing protrusion above the land surface.

Compaction that has occurred at the sites is shown in figures 26 through 32. Data from multiple compactionrecorder sites will be discussed first. Inverted bar graphs showing monthly compaction for most of the sites are given in Part 3 (Bull and Poland, 1974, figs. 13-17). 
TABLE 1.-Summary of compaction-recorder installations

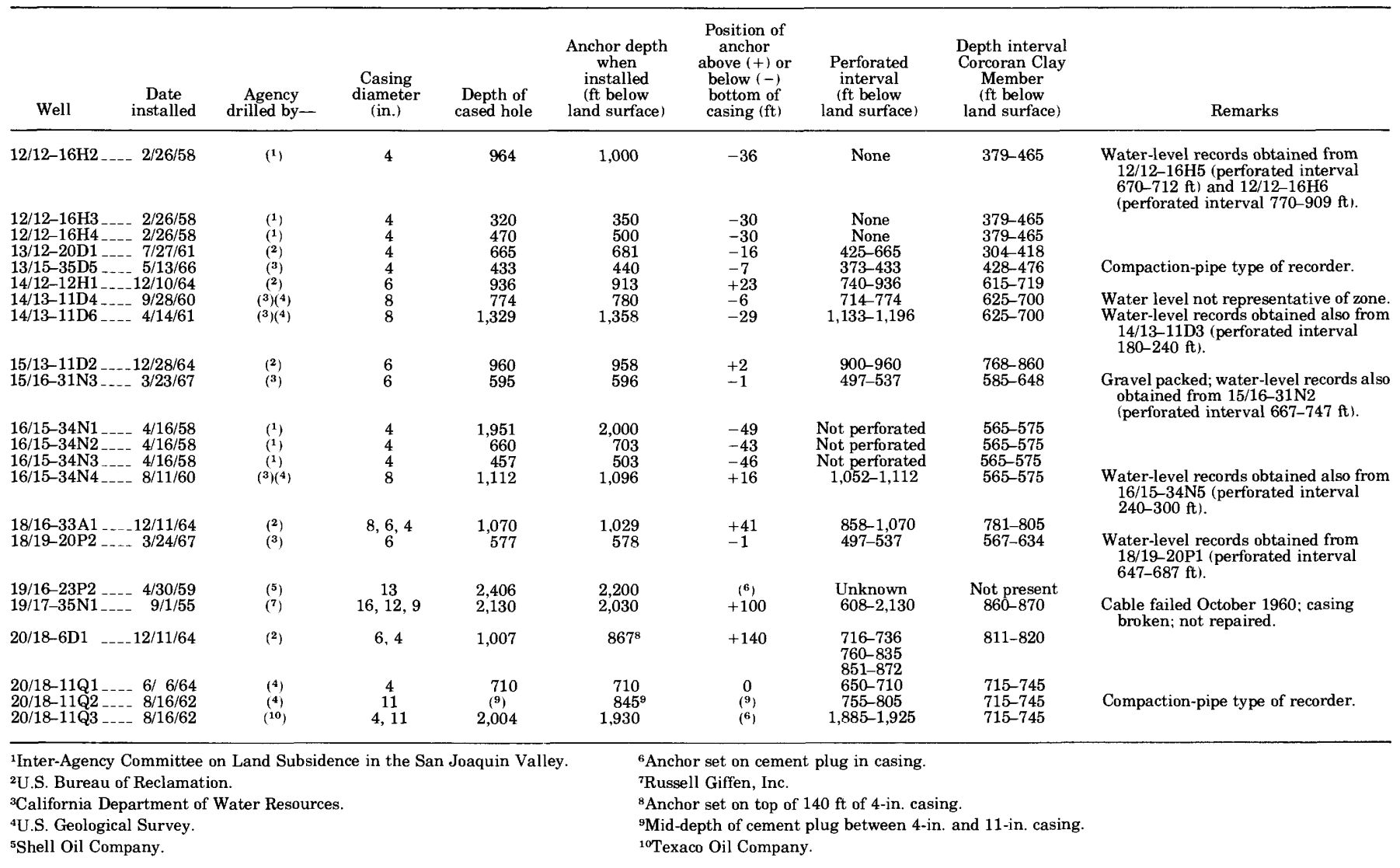

\section{ANALYSIS OF FRICTION IN A COMPACTION RECORDER}

The accuracy of the recorded compaction data is in large part dependent on the amount of friction within the compaction recording system. Friction occurs both in the recording equipment above the land surface and between the cable and the well casing below land surface. However, friction in the recording equipment is negligible, in comparison to casing-cable friction. The inaccuracies resulting from casing-cable friction are minimized by large-diameter straight casings and through the use of cables with minimum friction characteristics and high elastic modulus (minimum stretch per unit length per unit tension).

If the tension gradient due to the unit weight of the cable is neglected, the tension in a free-hanging cable may be considered uniform. However, a typical compaction cable does not hang freely, and the tension is approximately uniform only in the parts of the cable suspended between points of frictional contact with the casing. Tension above the uppermost point of contact between cable and casing equals the counterweight. Below this point the tension is different in each suspended segment.

Figure 24 illustrates, diagrammatically, a compaction- recorder system that has friction between the casing and the cable, owing to a bend in the casing. For simplicity, only the uppermost point of contact between the casing and the cable is shown $(B)$, and it is assumed that the cable does not touch the casing between point $B$ and the anchor weight. Actually, the cable may be partly or wholly in contact with the casing below point $B$.

In the situation portrayed in figure 24 , any change in aquifer-system thickness above point $B$ will be recorded accurately if friction in the above-ground components of the instrument is negligible. Above point $B$, constant cable tension is maintained at all times by the counterweights.

Below point $B$, cable tension will, in general, not remain constant. During compaction, cable tension between $B$ and $C$ will decrease until the cable stress between $B$ and $C$, plus the friction at point $B$, is exceeded by the cable stress induced by counterweighting above the land surface. Relative upward cable movement past point $B$ will then occur, and concurrently stress in the cable between $B$ and $C$ will increase rapidly until friction at $B$ prevents further movement. The cable between $B$ and $C$ may never attain the same stress as the cable between $A$ and $B$, as long as compaction continues.

An opposite relation exists during times of net 


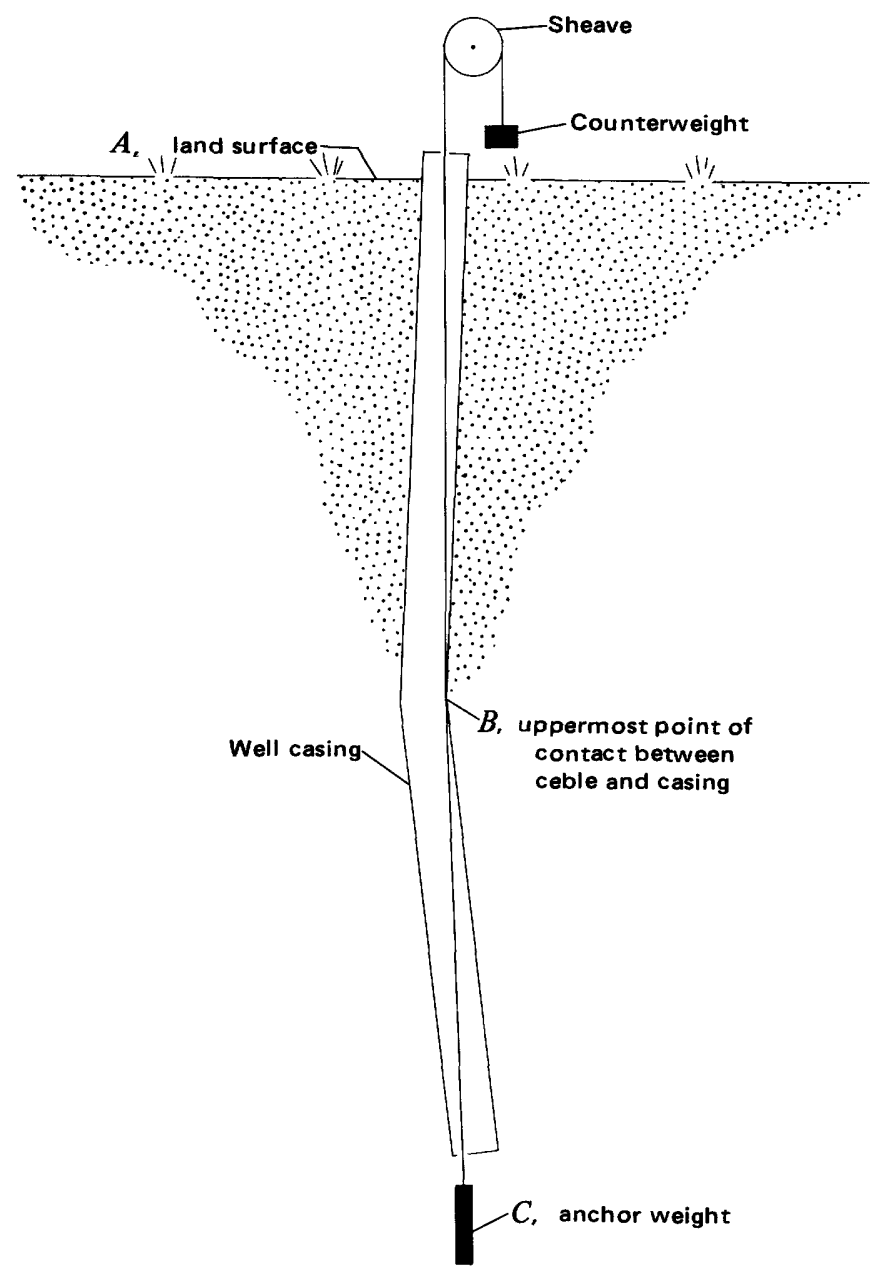

FIGURE 24.-Diagrammatic sketch of a compaction-recorder system with casing-cable friction.

aquifer-system expansion. During expansion of the deposits and well casing below point $B$, cable tension will increase until it exceeds the cable stress between $A$ and $B$, plus the friction at $B$. Downward cable movement past point $B$ will then occur, and stress in the cable between $B$ and $C$ will decrease rapidly until friction prevents further movement past point $B$. The cable between $B$ and $C$ may remain more highly stressed than between $A$ and $B$, as long as expansion continues.

Expansion or compaction below the uppermost friction point will not be recorded unless unbalanced cable stresses across that point exceed the friction at that point. Installations having little friction generate a moderately smooth and reasonably accurate compaction record. Installations with large amounts of friction generate a stepped compaction record, with most or all of the compaction recorded at times when differences in cable stress exceed the friction. If undisturbed, recorders with large amounts of casing-cable friction may show no compaction for many months and then suddenly record several tenths of a foot of compaction.
A partial solution to the problem of excessive friction is to change the stress on the cable artificially each time the instrument is serviced. This is done simply by pushing the counterweights down about 1 foot, or less, and allowing them to rise gently as the force is relaxed. This operation temporarily increases the stress imbalance across friction points enough to allow the cable to move upward against friction, thereby removing those differences in cable tension that have accumulated as a result of compaction since the last application of stress. When the cable comes to rest after relaxation of the load, a new vertical distribution of stresses will have been imposed in the cable. The difference between the old and new stress distributions is a measure of the compaction that has occurred since the last time the cable was loaded in the same way. If the periodic loading of the cable is done in a highly consistent way and if the elastic properties of the cable and the friction characteristics of the casingcable contacts change little with time, then the vertical distribution of stress within the cable should be nearly the same after each loading. Thus the cable length corresponding to this characteristic distribution of stress constitutes a nearly unchanging reference against which to measure compaction of the aquifer system.

An example of a record from a compaction recorder with large amounts of casing-cable friction is shown in figure 25 . The amount of friction within this well probably is as severe as for any in operation and is caused by the use of a cable with high friction characteristics (plastic coated) in a deep well $(2,000 \mathrm{ft}$ ) that has a small diameter casing (4 in.). During the first year of operation, before the cable was stressed monthly, this installation would record no compaction for 6 months and then would record more than 0.5 foot of compaction at one time. The record shown in figure 25 is stairstepped because compaction is recorded only at the time of each

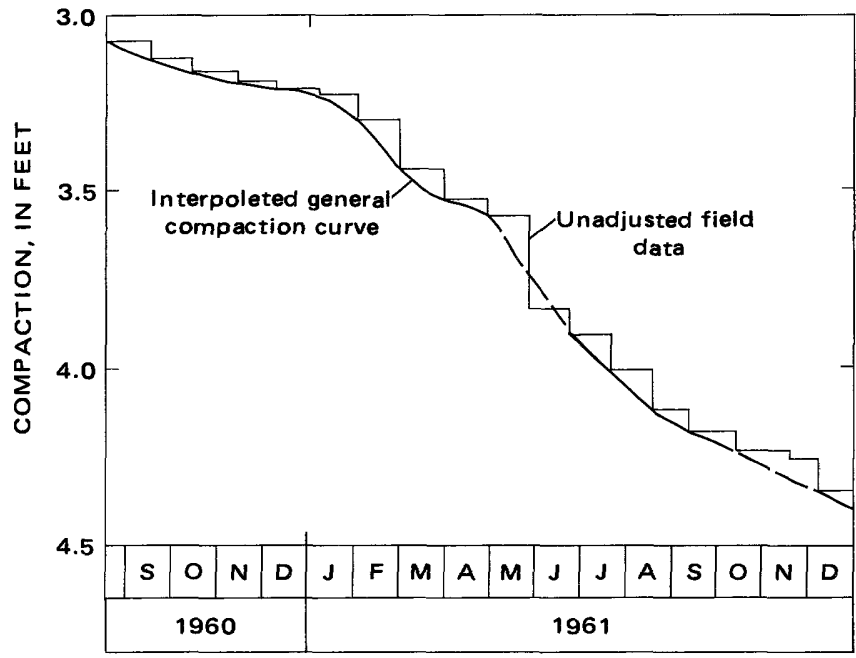

Figure 25.-Interpolation of part of the cumulative compaction record from well $16 / 15-34 \mathrm{~N} 1$. 
monthly stress increase. For most of the record, an interpolated cumulative compaction curve can be drawn through the low points of the stairstepped record. When the cable appears to have been overstressed (mid-1961) or understressed (late 1961), the value for that month (or months) is omitted, and the amount of compaction for two or more months is combined, as shown by the dashed lines. The method is accurate for determining compaction that has occurred for periods longer than 2 or 3 months because the cable probably returns to a similar distribution of stresses after most monthly stress increases.

\section{CUMULATIVE COMPACTION AT MULTIPLE COMPACTION-RECORDER SITES}

Plots of cumulative compaction and subsidence for those sites where two or three compaction recorders are operating are shown in figures 26-28. The plots are interpretations of stairstepped records similar to that shown in figure 25, and the dashed parts of the record indicate where more than one month's record has been combined. By mid-1968, 10 feet of cumulative compaction had been measured by one recorder. The unit compaction of the deposits in the different depth zones is discussed later.

Compaction and subsidence at the Oro Loma site in the northern part of the area are shown in figure 26. About 12 feet of subsidence occurred at this site between 1920 and 1966 (fig. 9). The maximum rate of subsidence was in $1954\left(0.9 \mathrm{ft} \mathrm{yr}^{-1}\right)$, and since then the rate has decreased steadily (fig. 22). The change in slope of the plot for bench mark 97.68 (USBR) reflects the decreasing subsidence rate for the 1958-66 period.

The compaction anchors at the Oro Loma site were set at depths of 350,500 , and 1,000 feet. The 1958-66 compaction was less than half a foot for the two shallow recorders, but more than 2 feet of compaction occurred in the $0-1,000$-foot interval. The large amounts of apparent compaction that occurred during the first 3 months of operation in 1958 probably were caused by initial cable stretch and foundation settlement. If the first few months of record are omitted, the total compaction in the upper 350 feet has been only 0.1 foot in the 7 years since 1958 .

The plots for wells $16 \mathrm{H} 3$ and $16 \mathrm{H} 4$ show periods of apparent net expansion of the aquifer materials prior to 1963. Similar effects are noticeable for the plot of well $16 \mathrm{H} 2$, but they are not as obvious as in the records from the other two recorders because of the greater compaction rate. The expansion is not real, but is chiefly a combination of soil and lumber swell during the winter rainy season. In April 1962, the installations for wells $16 \mathrm{H} 3$ and $16 \mathrm{H} 4$ were rebuilt, using steel racks set on large concrete pads that are not in contact with the casings. Little apparent aquifer-system expansion has occurred during the rainy season since the site was rebuilt. The recorder for well $16 \mathrm{H} 2$ was rebuilt in a similar fashion in October 1960.

A seasonal effect is noted for some years in the compaction record of well 16H2. For example, in 1963 the maximum compaction rate occurred in February and July-September-the months of large demand for irrigation water.

A comparison of the compaction in the upper 1,000 feet to the total amount of subsidence can be made by examining the record for well $16 \mathrm{H} 2$ and the plot for nearby bench mark 97.68 (USBR). If all the subsidence were the result of compaction in the upper 1,000 feet, the two plots would parallel each other.

The Oro Loma site has experienced a change in the amount of compaction being measured compared with subsidence, as is indicated by the divergence of the subsidence and compaction plots after 1961. During the period October 1958-October 1961, about 90 percent of the subsidence was the result of compaction in the upper 1,000 feet. The percentage decreased to about 55 percent for the period October 1961-October 1965 when about 45 percent of the compaction occurred below 1,000 feet.

Compaction and subsidence plots for the Mendota site (about $8 \mathrm{mi}$ west-southwest of the town of Mendota) are shown in figure 26 . The site, which subsided about 23 feet between 1920 and 1966, is in one of the areas of most intense land subsidence in the study area. The rate of subsidence increased until the mid-1950's and has decreased since then. The 1961-66 subsidence trend is shown by the plot of bench mark GW4.

Compaction anchors at the Mendota site were set at depths of 780 and 1,358 feet. During the period shown in figure 26, 0.9 foot of compaction occurred in well 11D4, and 2.85 feet of compaction occurred in well 11D6.

The Mendota site recorders were built using concrete pads and steel racks and do not show the effects of soil and lumber swell as noted during the first few years of record at the Oro Loma site.

The compaction rate varies with the season. Both wells show a pronounced reduction of compaction rate during the winter months. The times of maximum compaction vary from year to year, but in general roughly correspond with the times of irrigation in the summer and late winter-early spring.

The lesser overall slope of the compaction plot for well 11D6 as compared with the bench-mark plot reveals that part of the subsidence is occurring below 1,358 feet. During the period September 1961-August 1965, about 69 percent of the subsidence occurred as compaction between the land surface and 1,358 feet, and about 31 percent of the subsidence was attributed to compaction of deposits below 1,358 feet. About 23 percent of the 

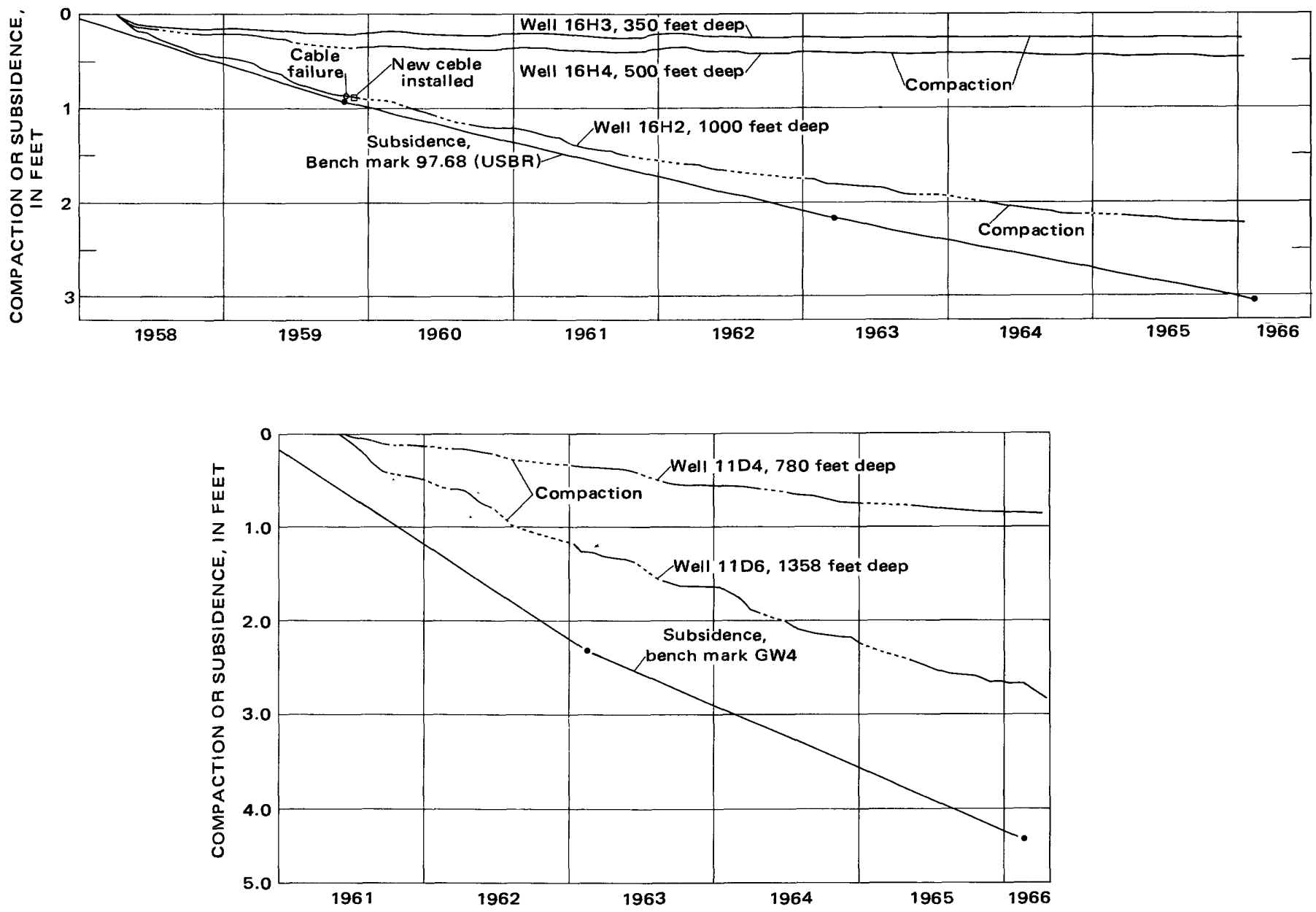

FIGURE 26.-Compaction and subsidence at the Oro Loma site, 1958-66 (upper graph), and Mendota site, $1961-66$ (lower graph)

compaction occurred between the land surface and a depth of 780 feet, and 46 percent between depths of 780 and 1,358 feet.

Compaction and subsidence plots for the Cantua site in the central part of the Los Banos-Kettleman City area are shown in figure 27 . About 19 feet of subsidence occurred at the site between 1924 and 1966, but more than 9 feet has occurred since 1957 . The subsidence rate has been rapid and fairly constant since the early 1950 's.

In 1958, compaction anchors were set at depths of 503, 703 , and 2,000 feet. In 1961, an additional anchor was set at 1,096 feet in a well that was drilled primarily to obtain lower-zone water-level information. All the recorders were rebuilt on concrete pads in April 1962. Records were interrupted when corrosion caused the galvanized cables to break in May 1959 in well 34N1 and in December 1959 in well 34N2. The record for the 0-1,096-foot depth interval in well $34 \mathrm{~N} 4$ was terminated in June 1963 when attempts to repair casing breaks caused by subsidence failed. Separation of two casings (a compaction-pipe type of gage) has provided compaction information for the 0-900-foot depth interval for well $34 \mathrm{~N} 4$ since February 1965. The casing for well $34 \mathrm{~N} 1$ has not failed, apparently because of the slip joints placed at several depths, even though 10 feet of casing shortening had occurred by mid-1968.

In contrast with the Mendota site, the Cantua site record shows less variation of compaction with the season of the year, although in some years the compaction rate decreased moderately during the winter.

The 2,000-foot recorder measures most of the subsidence that is occurring. For the period December 1959-December 1962, about 99 percent of the compaction was occurring in the upper 2,000 feet. About 10 percent of the compaction was measured above 503 feet, and about 26 percent of the compaction was measured above 703 feet. During the next 3-year period, December 1962-December 1965, the amount of subsidence remained about the same. However, the 2,000-foot recorder measured only about 88 percent of the subsidence, indicating that about 12 percent of the compaction was occurring below 2,000 feet. During this second 3 -year period, about 8 percent of the compaction was 


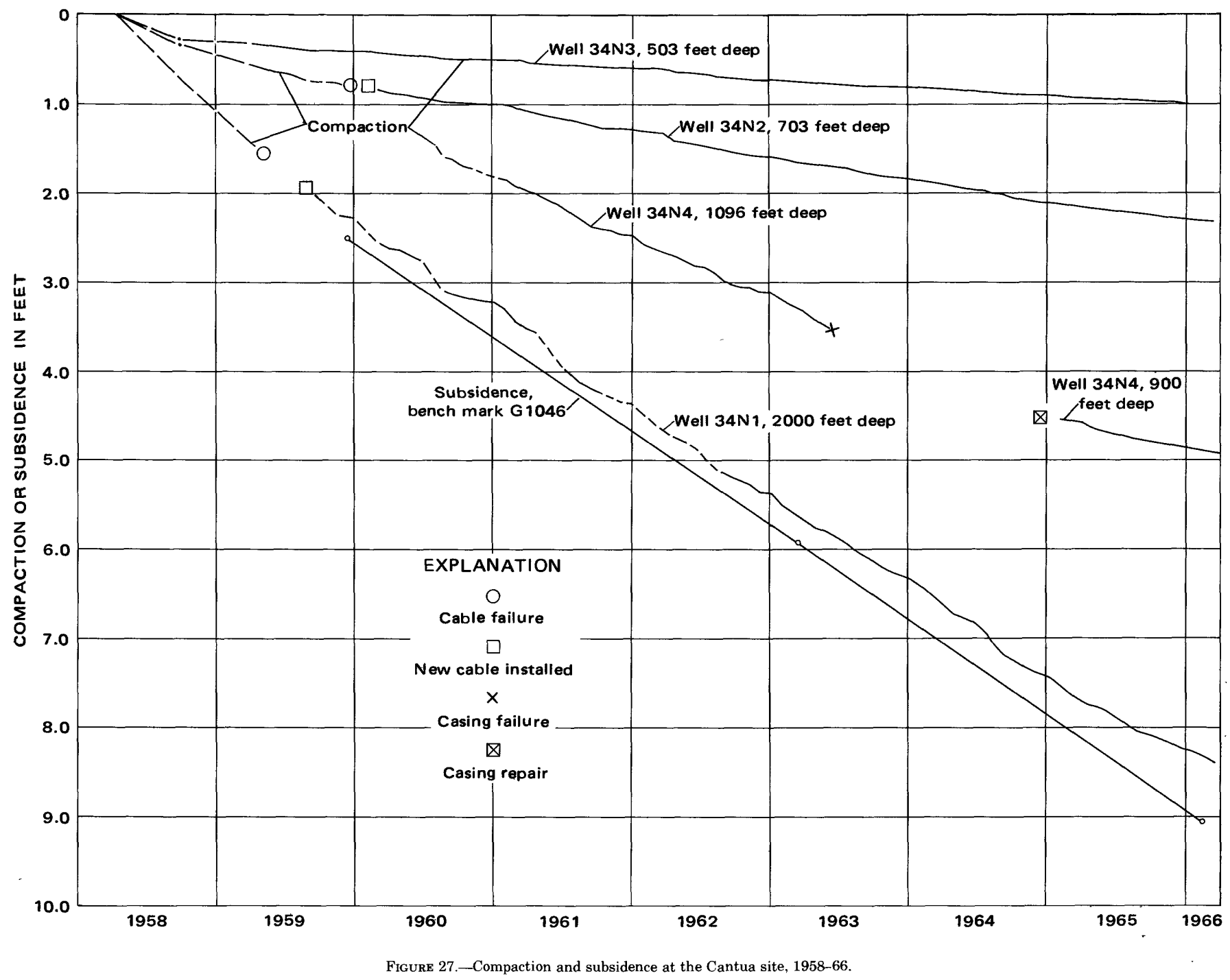

measured in the upper 503 feet, and about 22 percent of 100 the compaction was measured in the upper 703 feet of the deposits. The percentage of subsidence being measured decreased still further during the March 1966-November 1967 period, being only 79 percent of the subsidence. The decrease in the percentage of subsidence measured in the 0-2,000-foot depth interval at the Cantua site between 1959 and late 1967 is shown in figure 28.

Three compaction recorders-two cable type and one pipe type-are operating at the Westhaven site in the southern part of the Los Banos-Kettleman City area. The instrumentation of well 20/18-11Q2 consists of a 4-inch pipe cemented inside an 11-inch pipe at a depth of $830-860$ feet. Compaction is measured by observing the amount of shortening of the 11-inch casing as compared with a reference point on the 4 -inch casing and adding the minor amounts of change in protrusion of the 11-inch casing. The construction of this abandoned oil

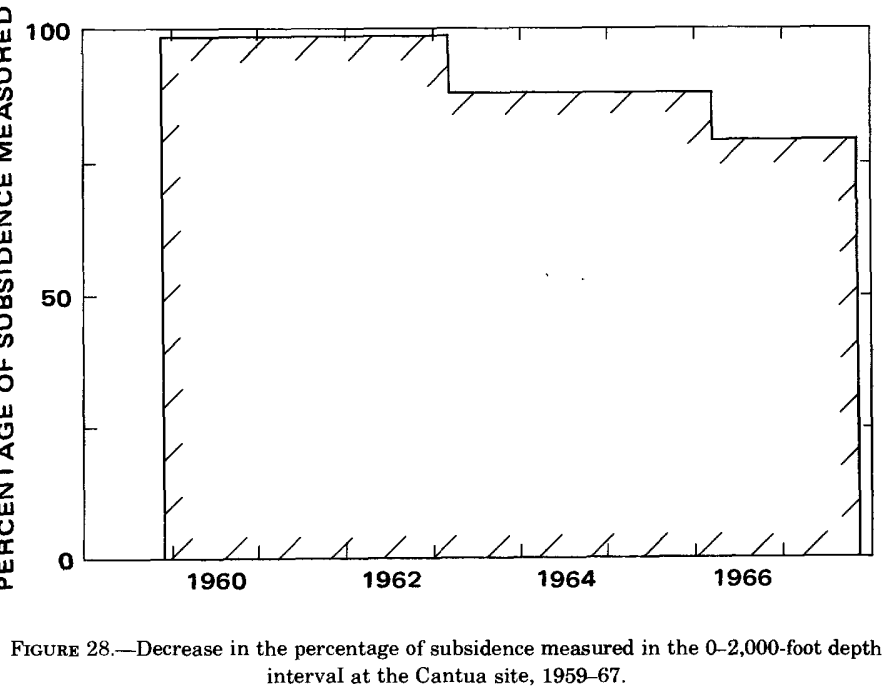

well is described in detail in the section "Shortening and Increased Protrusion of Well Casings." 
Compaction and subsidence plots for the Westhaven site are shown in figure 29. About 13 feet of subsidence occurred at the site between 1928 and 1963. The plot of subsidence in figure 29 is taken from two subsidence maps because vertical control was not extended to the site until the 1966 leveling. The amount of subsidence shown for the 4-year period probably is within 0.2 foot of the amount that would have been observed if a bench mark at the site had been surveyed, because a level line is located 1 mile west of the site.

Compaction is being measured above depths of 710 , 830 , and 1,930 feet. All three plots show pronounced seasonal variations in the rate of compaction. Maximum compaction rates occur in the summer and in late winter. Compaction virtually ceases in early winter and early spring.

The plots of subsidence and of compaction in the upper 1,930 feet are nearly parallel, and probably more than 95 percent of the compaction is occurring above this depth.

\section{CUMULATIVE COMPACTION AT SINGLE COMPACTION-RECORDER SITES}

As of 1968 , single compaction recorders were operating at 9 sites throughout the Los Banos-Kettleman City area. Only two of the records are sufficiently long to warrant illustration in this report, and at most of the sites, bench-mark altitudes were not established until 1966.

Well 13/12-20D1 was one of many wells drilled by the Bureau of Reclamation to obtain geologic and hydrologic information along the alinement of the San Luis Canal. About 10 feet of subsidence has occurred in the area between 1920 and 1966. Leveling has not been extended to the site itself, but subsidence maps provide a fairly accurate estimate of the amounts and rates of subsidence because of level lines 1 mile to the west, and to the south of the site.

The plot for well 20D1 (fig. 29) shows a steadily decreasing compaction rate into 1965 , but the excessive compaction rate in the first 3 months of record may be the result of initial cable stretch and foundation settlement. Consistent seasonal fluctuations of compaction are not readily apparent in the record from this well, and long-term and seasonal changes in artesian head of the upper part of the lower zone have been minor.

The well is in an area of near-surface subsidence, and compaction due to wetting of unsaturated deposits has occurred in addition to the compaction of saturated deposits. A Bureau of Reclamation evaluation of the amount of compaction due to wetting in a 230 -foot well at the site indicates that virtually no net compaction due to wetting occurred during the 4-year period. Apparently, percolation of irrigation water has thoroughly wetted all the deposits above the water table.
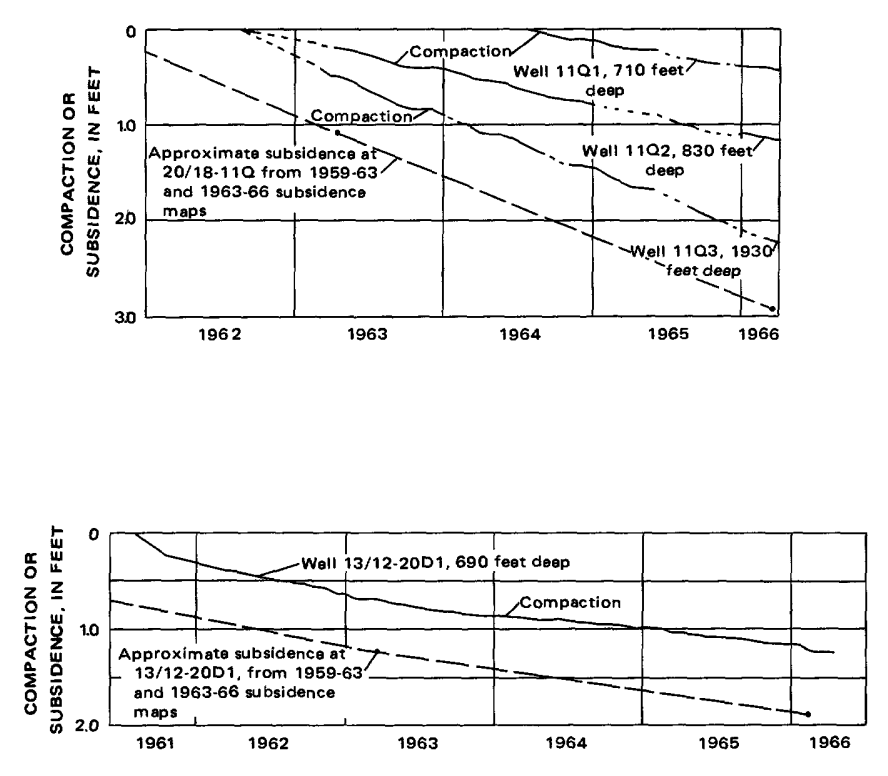

FIGURE 29.-Compaction and subsidence at the Westhaven site, 1962-66 (upper graph), and well 13/12-20D1, 1961-66 (lower graph.)

Comparison of compaction with estimated subsidence for the period December 1961-December 1965 indicates that about 90 percent of the compaction during the 4 years occurred above 690 feet and that 10 percent of the compaction occurred below 690 feet.

Well 19/16-23P2 is an oil test abandoned in 1950, in which a cement plug has been set in the casing at $2,200-2,406$ feet. Seven feet of subsidence occurred at the site during the 1928-66 period. The use of the well has provided the Geological Survey with the deepest compaction recorder in the study area. The $133 / 8$-inch casing greatly reduces the casing-cable friction. Despite the potential of the site, the recorder has had many problems. The recorder has been rebuilt several times, and the cable has been removed from the well five times because of corrosion failure or replacement or to make other changes in the equipment. In 1966, the recorder was rebuilt completely, using the most advanced equipment available, and since then a record of both aquifersystem compaction and expansion have been obtained without changing the cable stress by monthly oscillations of the counterweight. The record of net expansion is discussed in Part 3 (Bull and Poland, 1974).

Compaction at 19/16-23P2 and subsidence at bench mark Z888-about 500 feet southwest of 23P2-are shown in figure 30 . Because of the months of recorded net expansion and the instrumentation problems, many of the monthly records have been combined and are shown by a dashed line. Casing shortening is being measured because the anchor weight is set at a depth of 2,200 feet on a concrete plug in the casing. However, shortening of the casing is virtually the same as the concurrent shortening of the deposits that encase it, as 


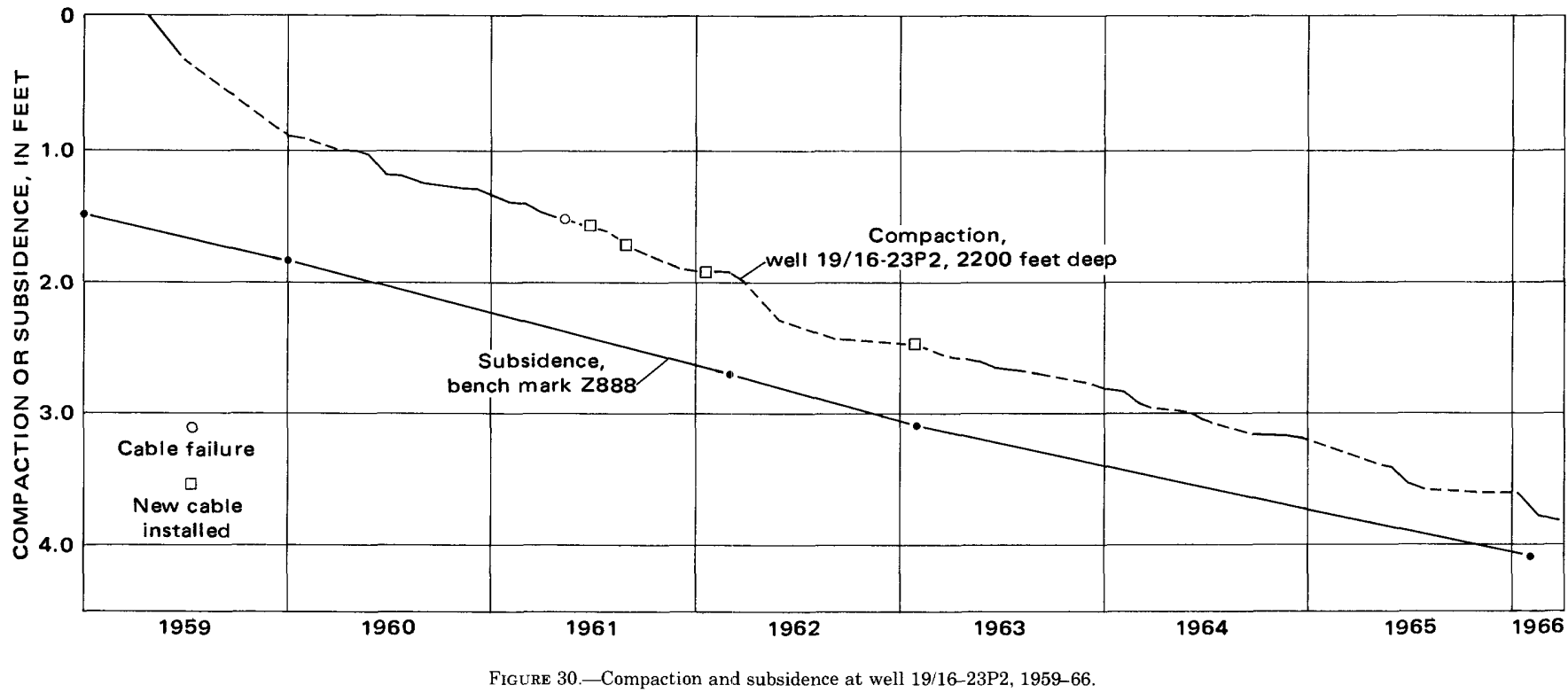

is shown by negligible amounts of increased casing protrusion above the land surface. Consistent seasonal patterns of compaction do not occur at this site because the compaction is dependent to a large extent on the pumping schedule of well $23 \mathrm{P} 1$, about 500 feet to the southwest. Well 23P1 pumps more often during the winter months than most of the wells in the Los Banos-Kettleman City area.

Comparison of compaction at well $23 \mathrm{P} 2$ and subsidence at bench mark Z888 suggests that compaction is being measured in excess of subsidence. During the period December 1959-December 1965, measured compaction was about 122 percent of the subsidence at bench mark Z888. The compaction cable was not removed from the well between the times of leveling in March 1963 and March 1966. Compaction was about 120 percent of the subsidence during the 1963-66 period. Subsidence rates change rapidly from west to east in the vicinity of $23 \mathrm{P} 2$ (fig. 13). Less subsidence should occur at bench mark Z888 because it is 500 feet to the southwest of 23P2. Steep subsidence gradients are not uncommon in the Los Banos-Kettleman City area. An example would be the subsidence of bench marks P692 and N692 (fig. 15), where bench marks 1 mile apart have subsided 4 and 16 feet, respectively.

Post-1966 leveling substantiates the presence of a marked subsidence gradient in the vicinity of well 19/16-23P2. The bench mark in the concrete pad of the recorder site was first leveled in March 1966 and was releveled in March 1967 and December 1967. Neither of the post-1966 periods indicates that the measured compaction exceeds subsidence. Measured compaction above a depth of about 2,200 feet is only slightly less than the subsidence. For the period from March 1966 to
March 1967, the data indicate that about 98 percent of the subsidence is being measured. Thus the presence of abrupt lateral changes in subsidence rate have been verified at the site. The leveling record shows that from March 1966 to March 1967 about 20 percent more subsidence occurred at the compaction-recorder well than at bench mark Z888.

In September-December 1964, the Bureau of Reclamation drilled four wells, principally for the purpose of monitoring lower-zone potentiometric head changes along the San Luis Canal (wells 14/12-12H1, 15/13-11D2, 18/16-33A1, 20/18-6D1). The wells are 868-1,070 feet deep, and compaction recorders have been installed in them by the Geological Survey in order to provide information regarding the maximum amount of compaction that might be occurring in the upper water-bearing zone. The compaction recorders are operating satisfactorily, and the preliminary results from them are used in the discussion of compaction above and below the Corcoran Clay Member. (See section "Proportions of Compaction Occurring in the Upper and Lower Zones.")

In 1965, the California Department of Water Resources drilled well $13 / 15-35 \mathrm{D} 5$, and in 1966 , wells $15 / 16-31$ N2, 3 and 18/19-20P1, 2. The Geological Survey has installed equipment to observe compaction and water-level changes in these wells. At each site, a well was drilled to the Corcoran and a compaction recorder was installed in order to measure the amount of compaction between the land surface and the Corcoran. 'Total subsidence will be obtained by periodic leveling to a bench mark set in the concrete pad. These wells should help evaluate compaction rates in areas where ground water is mostly pumped from the upper zone. 
UNIT COMPACTION AT THE MULTIPLE COMPACTION-RECORDER SITES

The setting of compaction anchors at various depths at a given site affords a means of measuring the amounts of compaction occurring in the depth intervals between the anchors. The amounts of compaction per foot of deposits for each calendar year are given in table 2 , and unit compaction for 1-year or 2-year intervals is shown for the multiple compaction-recorder sites in figures 31 through 34 . The thickness values exclude deposits above the water table. Changes in the position of the water table have been minor during the period of record at all the multiple compaction-recorder sites.

Although the percentage compaction for the various depth zones is shown to the nearest percent, it is probable that the measurements are accurate to only within several percent. Errors can be introduced by initial cable stretch and foundation settlement, casing-cable friction, untwisting of the cable, and leveling to the bench mark. In general, the percentage compaction is more accurate at those sites with the most compaction.

Amounts of unit compaction vary from 0 for the 350-500-foot interval at the Oro Loma site to 0.00115 foot per foot per year for the 503-703-foot-depth zone at the Cantua site (table 2). Amounts of unit compaction vary by as much as 100 percent between various years.

Changes in unit compaction with depth for the Los Banos-Kettleman City area are the result of two factors-the increase in head decline to and across the Corcoran in much of the area and the decrease in compressibility with depth because of increasing prior overburden loads. Both upper- and lower-zone wells commonly are perforated in the first 100-200 feet below the Corcoran (Miller and others, 1971, pls. 3, 4), which suggests that this depth interval may have undergone the maximum head decline. The combined effects of both factors should result in increasing unit compaction to a depth of a couple of hundred feet below the Corcoran and then decreasing unit compaction below that depth. It is not economically feasible to install a sufficient number of compaction recorders at any one site to define the change in unit compaction within the lower zone. However, the variation in unit casing-failure ratio (fig. 45) suggests that unit compaction decreases below a depth of about $200-400$ feet below the bottom of the Corcoran.

Variation in unit compaction above the Corcoran is a function of the degree of confinement as well as variation in compressibility of the deposits. Compaction has not occurred in those deposits containing unconfined water where the position of the water table has not changed. With increasing depth, the upper-zone waters generally become better confined, and in the southern part of the area, good confinement is provided by several extensive lake clays above the Corcoran. Considerable variation in applied stress and unit compaction should be expected for the different lithologic and genetic units of the upper zone.

The mean annual unit compaction in three depth zones at the Oro Loma site are shown in figure 31 . The unit compaction was computed as the mean of two consecutive calendar years to reduce the year-to-year variation and to illustrate trends in unit compaction. The largest amounts of unit compaction have been in the 500-1,000-foot-depth interval which is entirely below the Corcoran Clay Member. A progressive and rapid decrease in unit compaction has occurred in this interval-the values of unit compaction for the 1964-65 period are only one-third those for the 1960-61 period. The reduction of compaction rate within this depth in-

TABLE 2.-Annual compaction rates

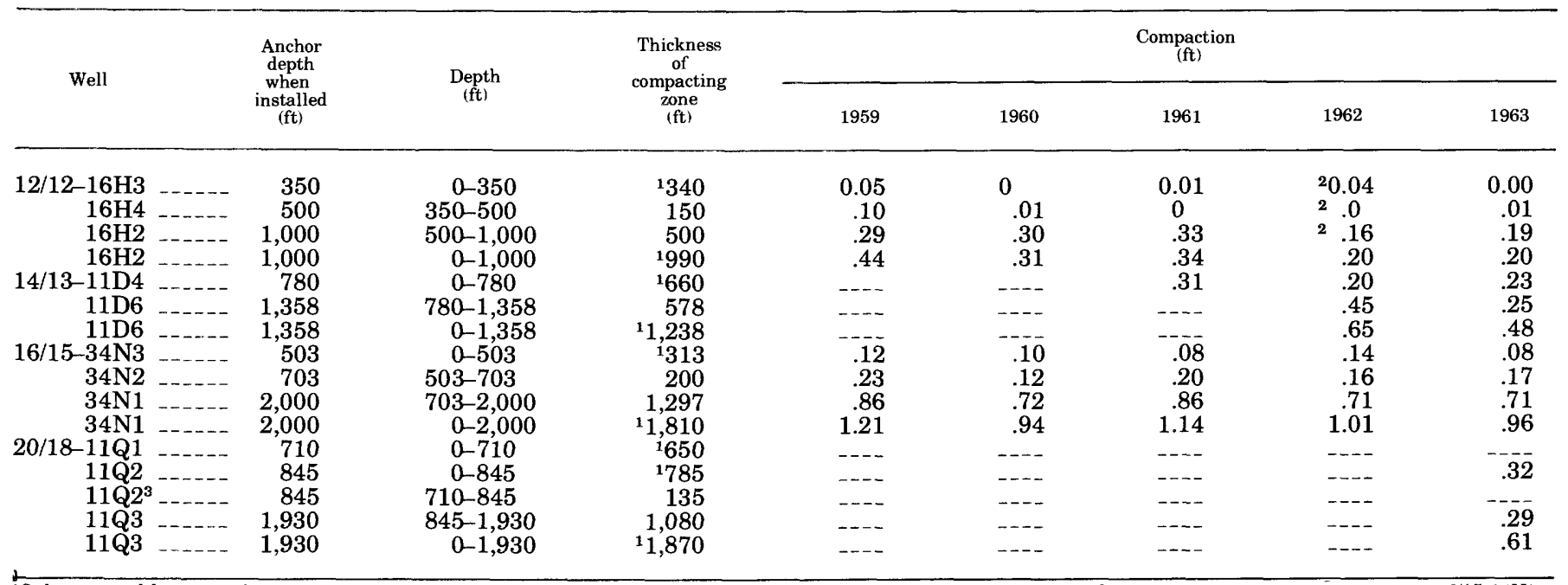

Only saturated deposits included in the compacting thickness. Depth to water table in 1965 was $10 \mathrm{ft}$ adjacent to $12 / 12-16 \mathrm{H3}, 120 \mathrm{ft}$ adjacent to $14 / 13-11 \mathrm{D} 4,190 \mathrm{ft}$ adjacent to $16 / 15-34 \mathrm{~N} 3$, and $60 \mathrm{ft}$ near 20/18-11Q3.

${ }^{2}$ Approximate values.

${ }^{3}$ Compaction measured as casing separation between well 20/18-11Q2 and well 20/18-11Q3 plus increased protrusion of casing of 20/18-11Q3. 


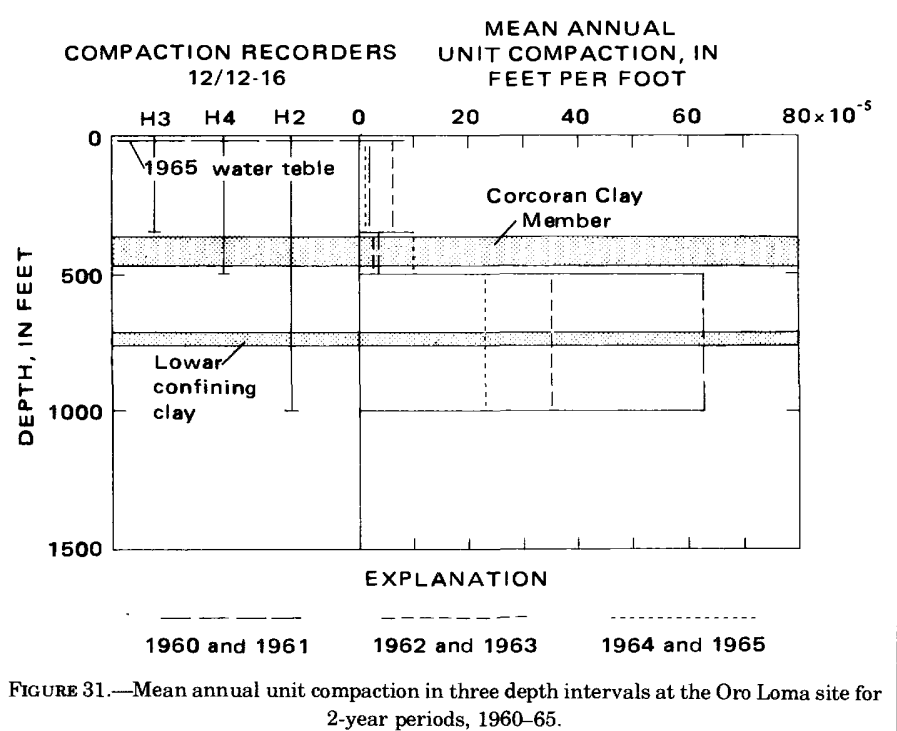

terval has been largely responsible for the decreasing rate of subsidence indicated by bench mark 97.68 USBR (fig. 22).

The mean unit compaction values in the upper two depth intervals at the Oro Loma site do not show a progressive change with time and have never exceeded half the unit compaction of the deepest interval. The largest unit compaction in the 10-350-foot-depth interval was during the 1962-63 period, and the largest unit compaction for the 350-500-foot interval was during the 1964-65 period. The amounts of compaction were only a few hundredths of a foot per year, at most, and never exceeded the amounts of compaction recorded in 1959.

The mean annual unit compaction at the Mendota site is shown in figure 32 . The unit compaction in the 780-1,358-foot-depth interval (table 2) ranged from 0.00043 to 0.00078 foot per foot per year for the 1962-65

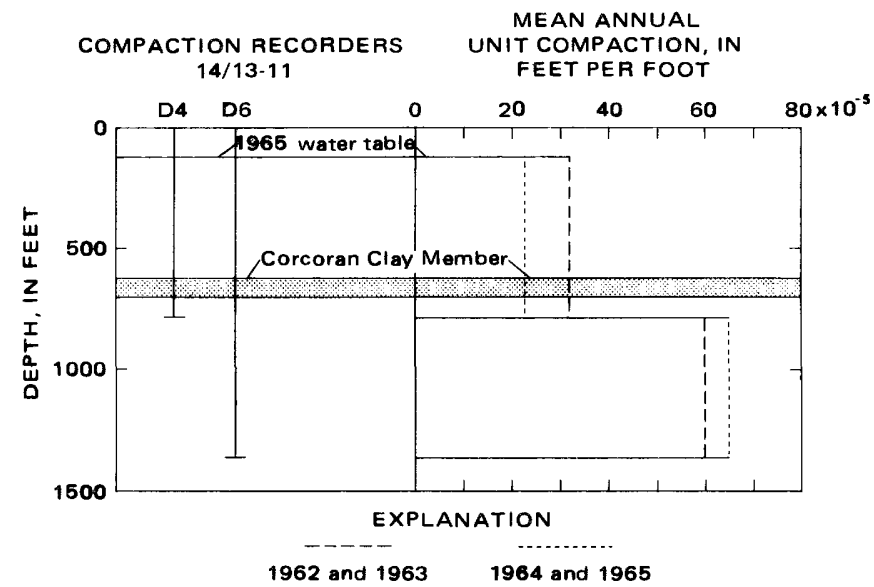

FIGURE 32.--Mean annual unit compaction in two depth intervals at the Mendota site for 2-year periods, 1962-65.

period. When the data are grouped into 2-year periods, a slight increase in the lower-zone compaction rate is suggested. The 0-780-foot-depth interval has had a decreasing rate of compaction, and the rate of compaction in the 0-1,358-foot-depth interval, although variable, has been decreasing (table 2 ).

The largest values of unit compaction in the study area have been measured at the Cantua site (fig. 33). Although the unit compaction for each depth interval is highly variable from year to year, the 1964-65 amounts are less than the 1960-61 amounts of compaction. The subsidence rate has decreased, and more compaction has been occurring below 2,000 feet in recent years, as was pointed out in the discussion of figure 28 . The highest unit compaction has been consistently in the 503-703-foot interval, which includes the deposits immediately above and below the Corcoran Clay Member, and in the Corcoran, which is only 10 feet thick at this site.

at multiple compaction-recorder sites

\begin{tabular}{|c|c|c|c|c|c|c|c|c|c|}
\hline \multicolumn{2}{|c|}{$\begin{array}{c}\text { Compaction-Continued } \\
\text { (ft) }\end{array}$} & \multicolumn{7}{|c|}{$\begin{array}{l}\text { Unit Compaction } \\
\left(\times 10^{-5} \mathrm{ft} / \mathrm{ft}\right)\end{array}$} & \multirow{2}{*}{$\begin{array}{c}\text { Interval } \\
\text { of } \\
\text { Corcoran } \\
\text { Clay } \\
\text { Member } \\
\text { (depth } \\
\text { in ft) } \\
\end{array}$} \\
\hline 1964 & 1965 & 1959 & 1960 & 1961 & 1962 & 1963 & 1964 & 1965 & \\
\hline 0.00 & 0.01 & 15 & 0 & 3 & 12 & 0 & 0 & 3 & \\
\hline .02 & .01 & 67 & 7 & 0 & 0 & 7 & 13 & 7 & $379-465$ \\
\hline .17 & .06 & 58 & 60 & 66 & 32 & 38 & 34 & 12 & \\
\hline .19 & .08 & --- & $-\cdots$ & & & & & & \\
\hline & .10 & - & $\cdots$ & 47 & 30 & 35 & 29 & 15 & $625-700$ \\
\hline $\begin{array}{l}.39 \\
.58\end{array}$ & .35 & $\cdots$ & --- & $\ldots$ & 78 & 43 & 68 & 61 & \\
\hline $\begin{array}{l}.00 \\
.10\end{array}$ & $\begin{array}{l}.40 \\
.08\end{array}$ & 38 & 32 & 26 & 45 & 26 & 32 & 26 & \\
\hline .17 & .11 & 115 & 60 & 100 & 80 & 85 & 85 & 55 & $565-575$ \\
\hline .83 & .63 & 66 & 56 & 66 & 55 & 55 & 64 & 49 & \\
\hline 1.10 & .82 & ---- & --- & -.- & $\ldots$ & --- & -... & $-\bar{x}$ & \\
\hline & .26 & --- & --- & $\ldots-$ & -..- & $\cdots$ & ---- & 40 & \\
\hline .34 & .31 & $\ldots$ & ---- & -..- & $\ldots$ & 41 & 43 & 39 & \\
\hline & .05 & --- & ---- & 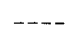 & $\ldots$ & & & 36 & $715-745$ \\
\hline .20 & .35 & $\ldots$ & --- & --- & $\ldots$ & 27 & 19 & 32 & \\
\hline .54 & .66 & $\ldots$ & --- & --- & -..- & --- & -..- & --- & \\
\hline
\end{tabular}




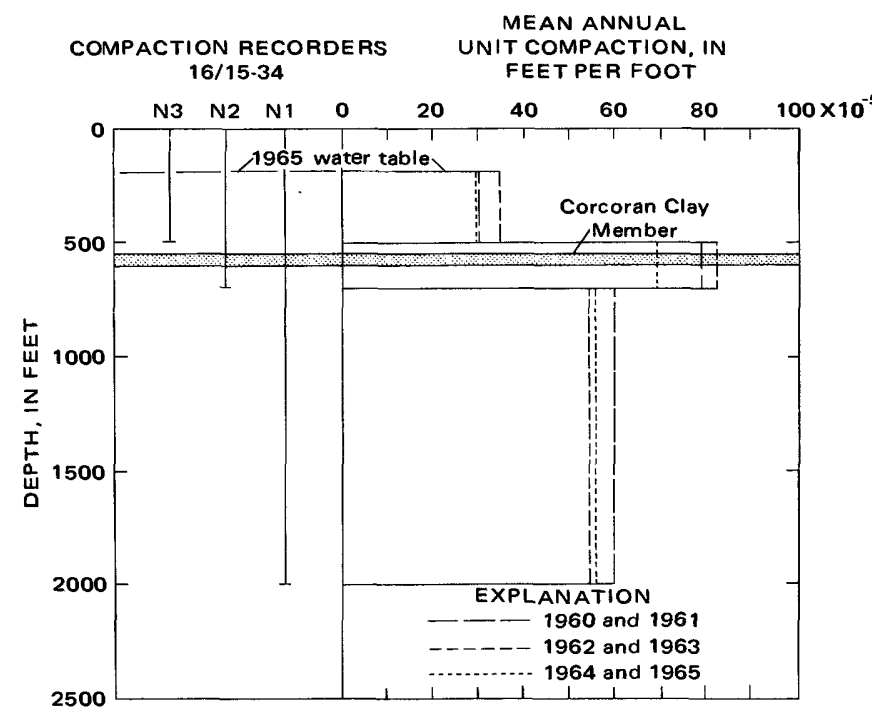

FIGURE 33.-Mean annual unit compaction in three depth intervals at the Cantua site for 2-year periods, 1960-65.

The unit compaction for the Westhaven site has been plotted for 1-year intervals in figure 34 . Trends in the rate of compaction are not readily apparent for the 3 years considered. The site is the only one that definitely shows larger amounts of unit compaction in the upper water-bearing zone than in the lower water-bearing zone, a subject that is discussed further at the end of the section "Casing-Failure Study."

Overall decrease in amounts of annual compaction for selected depth intervals at the multiple compactionrecorder sites is shown in figure 35. The data are from table 2 and plot with large amounts of scatter. Despite

COMPACTION RECORDERS ANNUAL UNIT COMPACTION,

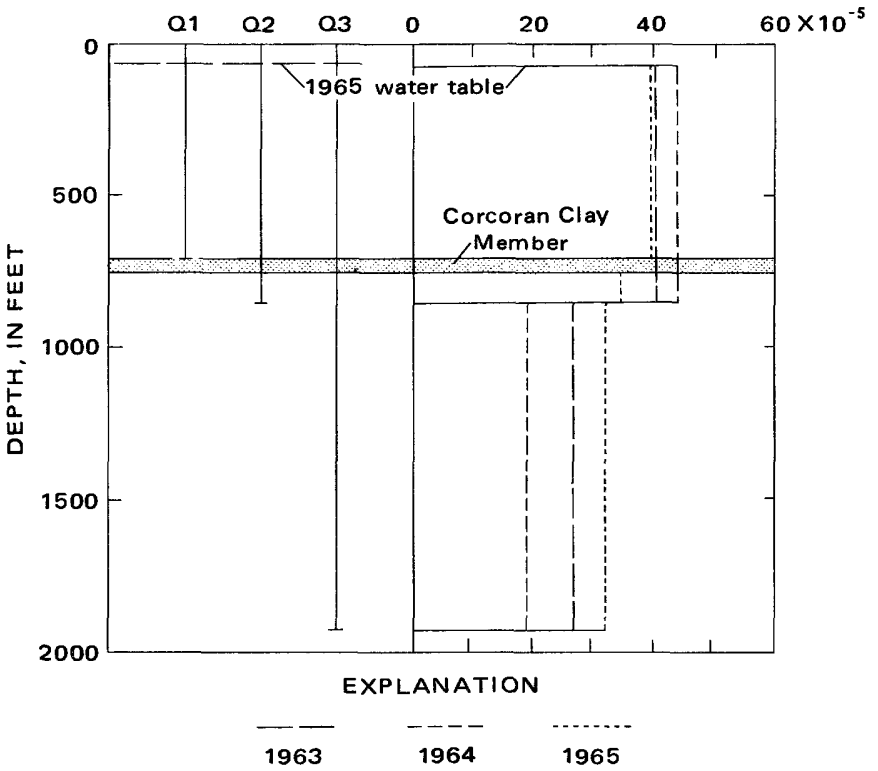

FIGURE 34.-Unit compaction in three depth intervals at the Westhaven site for 1-year periods, 1963-65.

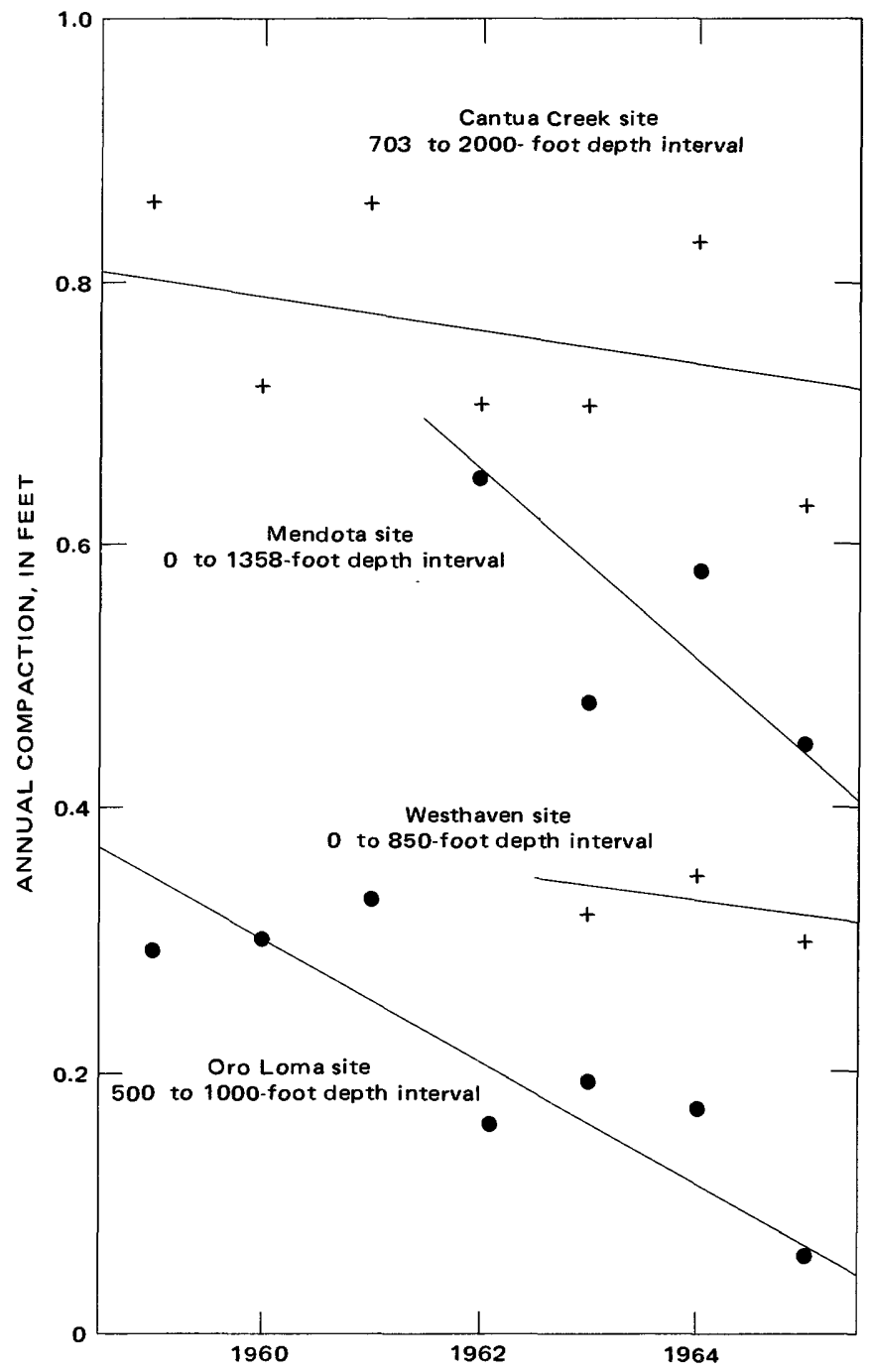

Figure 35.-Decrease in annual compaction for selected depth intervals at multiple compaction-recorder sites.

the scatter, the overall trend toward decreasing rates of unit compaction appears to be real. The rate of decrease in the amounts of annual compaction appears to be more rapid for the two sites in the northern part of the study area (Oro Loma and Mendota) than for the two sites in the central and southern parts of the area (Cantua and Westhaven). Possible geologic factors influencing the differences in decrease of compaction rate are discussed in the section "Geologic Factors Influencing Specific Unit Compaction." The decreases in compaction rate shown are not the result of hydrologic changes for at least three of the sites, as indicated by minimum potentiometric levels for the lower-zone aquifer system, during the periods of record in table 3 . At the Oro Loma and Cantua sites, the maximum annual depth to water in lower-zone wells had a range of only 3 feet, and at the Mendota site, the range was only 7 feet during the period of record. About 26 feet of head decline occurred 
TABLE 3.-Variation in the deepest annual water levels for selected depth zones at the multiple compaction-recorder sites, 1959-63

\begin{tabular}{|c|c|c|c|}
\hline \multirow{2}{*}{$\begin{array}{l}\text { Compaction-recorder site } \\
\text { and depth interval } \\
\text { (ft) }\end{array}$} & \multicolumn{2}{|c|}{$\begin{array}{l}\text { Depth to annual low } \\
\text { water level, } \\
\text { in feet, and year }\end{array}$} & \multirow{2}{*}{$\begin{array}{l}\text { Beginning of } \\
\text { water-level } \\
\text { record }\end{array}$} \\
\hline & High & Low & \\
\hline Oro Loma, 500-1,000 & 202,1963 & 205,1964 & $9 / 60$ \\
\hline Mendota, $780-1,358$ & 496,1962 & 503,1965 & $4 / 61$ \\
\hline Cantua Creek, 703-2,000 & 600,1961 & 603,1962 & $8 / 60$ \\
\hline Westhaven, $0-850$ & 450,1963 & 476,1965 & $19 / 58$ \\
\hline
\end{tabular}

Potentiometric level at base of upper zone.

at the Westhaven site after the compaction gage was installed, which may account, in part, for the low slope of the line showing decrease in annual compaction for the upper-zone depth interval at the Westhaven site in figure 35.

\section{SHORTENING AND INCREASED PROTRUSION OF WELL CASINGS}

Shortening and increased protrusion of well casings and the distribution of casing failures provide valuable information about the compaction of the water-bearing deposits. Compaction resulting from water-level change is deforming well casings throughout the Los Banos-Kettleman City area. More than 3,000 irrigation wells have been drilled during 50 years of expanding agricultural development, but only 1,100 active irrigation wells existed as of 1960 (Ireland, 1963). Most of the wells that have been abandoned or destroyed were damaged by the compaction of the sediments that encase them. Compaction has caused tens of millions of dollars of damage to well casings. For example, in 1965 it cost about $\$ 30,000$ to drill, case, and gravel-pack a 2,000-foot well (maximum water-well depth in the area is 3,800 feet). Where subsidence rates exceeded $0.75 \mathrm{ft}$ $\mathrm{yr}^{-1}$ (fig. 18), the average well has been abandoned or has undergone extensive repairs after only about 8 years. In areas where subsidence rates have not exceeded $0.5 \mathrm{ft} \mathrm{yr}^{-1}$, many wells are still in operation after 15 years of use, but casing repairs commonly are necessary.

An underwater photograph of a casing failure is shown in figure 36 . The light source was suspended under the camera. Machine-cut slotted perforations can be seen at the top of the photograph, and the circular cross section of the casing has been changed to a distorted oval. Compressional forces have ruptured the casing, and pebbles from the gravel pack can be seen on top of plates of sheared casing jutting into the well. Many water wells are ruptured in several places. Some ruptures can be repaired by swaging deformed parts of the casing and installing steel liners, but such repairs are costly.

Frictional resistance between the casing and adjacent deposits is cumulative with depth. Nonelastic deformation occurs after a critical stress is exceeded. The depth

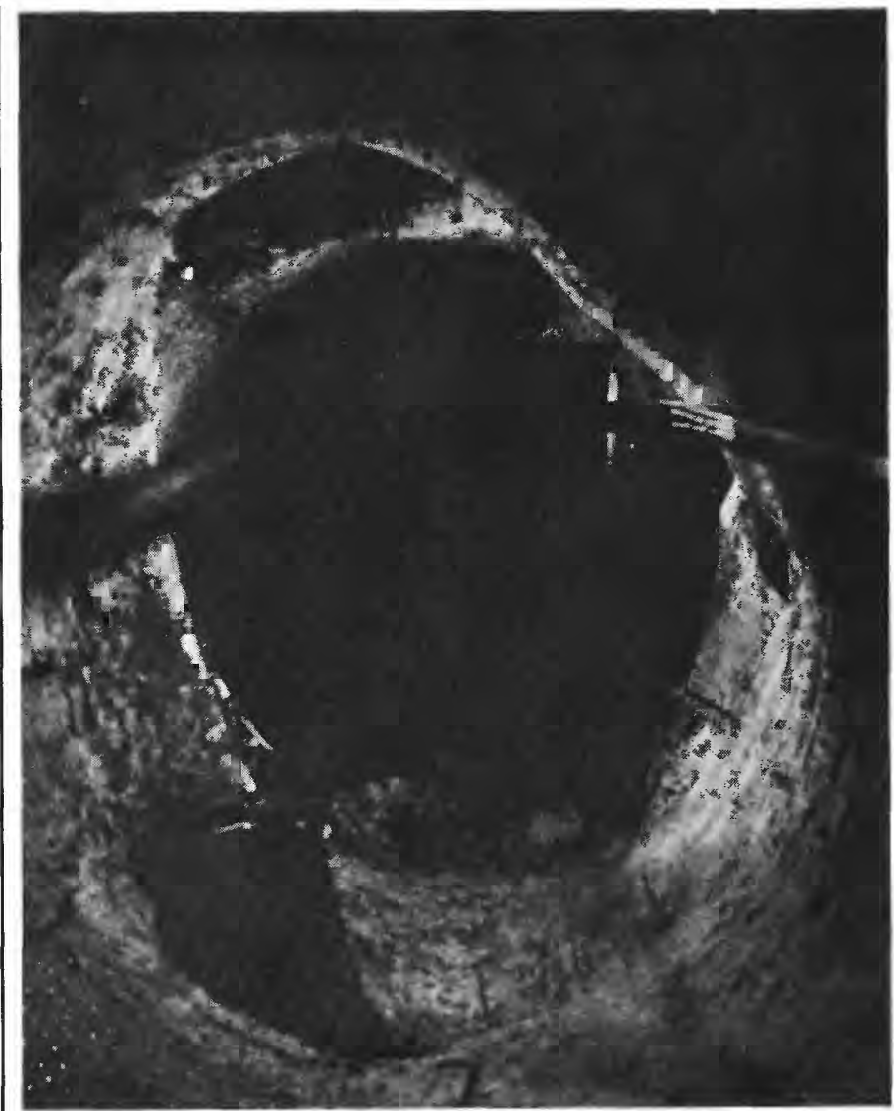

Figure 36.-Compressional rupture of an irrigation-well casing. (Photograph courtesy of Laval Underground Surveys, Inc.)

at which the critical stress is exceeded is a function of well factors such as mode of construction and casing diameter and strength as well as geologic factors such as lithology of the adjacent deposits and depth distribution, magnitudes, and rates of compaction. Above the critical depth, the enclosing sediments may move downward relative to the casing and result in increased casing protrusion at the land surface.

The combined effects of depth of the compacting interval and casing diameter as related to increased casing protrusion are shown in figure 37 . The upper limit of increased casing protrusion (dashed line, fig. 39) for the various casing diameters shows a progressive decrease with increasing casing diameter. Thus, in the Los Banos-Kettleman City area, large-diameter (large sediment-casing contact area) casings may deform more readily than do small-diameter (small sediment-casing contact area) casings. The data are from compactionrecorder wells operated by the Geological Survey, and the data for only one well were plotted for each multiple compaction-recorder site. The period of measurement was from September 1965 to September 1966. None of the wells are gravel packed, and none were pumped during the measurement period. 


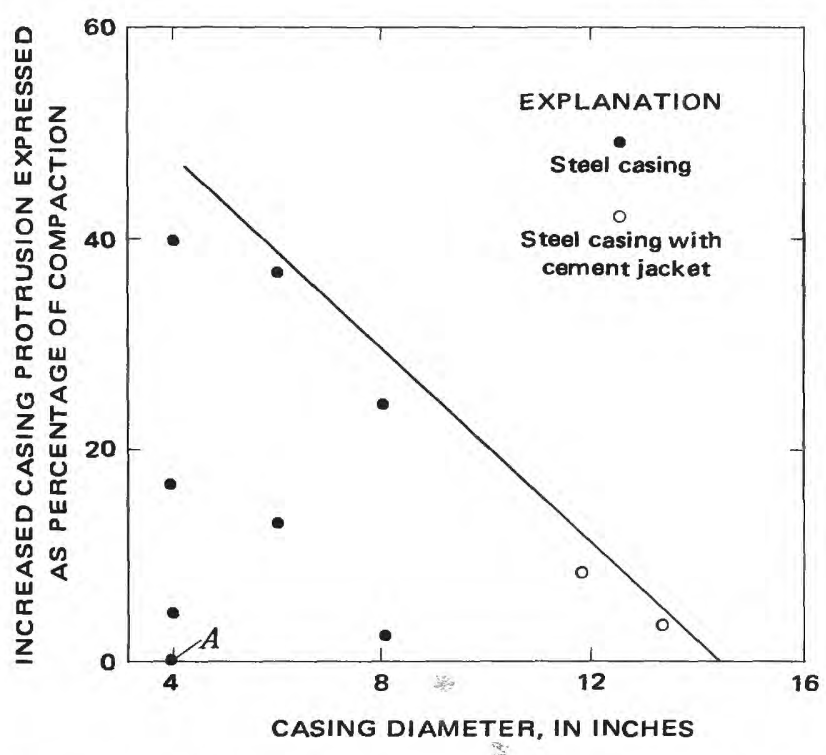

FIGURE 37. - Relation of increased casing protrusion to casing diameter for observation wells that are not gravel packed.

The range in amounts of increased protrusion for a given casing size is largely a function of the depth of the compacting interval. For example, well 12/12-16H2 (point $A$, fig. 37) is 1,000 feet deep, but 90 percent of the compaction occurs below 500 feet (fig. 31). During the period of measurement for figure 37, compaction apparently occurred entirely below the critical stress depth, and increased protrusion of the casing at the land surface did not occur, even though this well has a 4-inch casing. For most wells, some compaction due to waterlevel change occurs close enough to the land surface so that casing strength exceeds the cumulative casingsediment friction and small amounts of increased casing protrusion are noted. For three observation wells shown in figure 37 , increased casing protrusion exceeded 20 percent of the measured compaction.

\section{Shortening Of An Oil-Well Casing}

Observations of an oil-well casing at the Westhaven site (20/18-11Q3) show that even a heavy oil-well casing encased in a cement jacket is too weak to resist the compressional force of the compacting sediments and is being shortened virtually in accord with the compaction. Instrumentation of the well has resulted in the obtaining of data about casing shortening and protrusion, compaction, and water-level changes. Preliminary results were presented by Poland and Ireland (1965).

When the oil test was drilled by the Texas Co. in 1957, a surface string of $113 / 4$-inch casing with a wall thickness of 0.44 inch was set from the land surface to a depth of 2,004 feet. The seal to prevent contamination of the fresh ground water was completed by pumping cement into the annular space around the casing. When the oil test was abandoned, a cement plug was placed in the well between 1,930 and about 2,030 feet.

The Geological Survey converted the blank casing into a dual water-level well in April 1958. The casing was gun perforated from 755 to 805 and 1,885 to 1,925 feet. Hydraulic separation of the two intervals was done by the following method. A four-inch pipe with a packer attached was lowered inside the casing to a depth of 860 feet. A cement plug was placed on top of the packer, thus sealing the space between the 4 - and $113 / 4$-inch casings in the depth interval $830-860$ feet. A diagram of the converted well is shown in figure 38 .

Initially, the 4-inch casing was suspended by a casing hanger resting on top of the $113 / 4$-inch casing. Four months after installation, the casing hanger appeared to be rising off the top of the $11 \frac{3 / 4}{4}$-inch casing, indicating shortening of the 113/4-inch casing above the cement bond between the casings at a depth of $830-860$ feet. The cumulative separation (top of the 11/4-inch casing is below the top of the concrete pad in figure 39) was measured monthly, and by November 1969 the 113/4-inch casing had been shortened 3.30 feet.

Shortening of 1,930 feet of casing was measured, starting in August 1962, by setting a compaction anchor on top of the cement plug. Measurements of changes in the protrusion of the $11^{3 / 4}$-inch casing above the land surface were started in February 1963.

The measurements just described made it possible to measure casing shortening for the depth intervals $0-845,845-1,930$, and $0-1,930$ feet. Compaction to

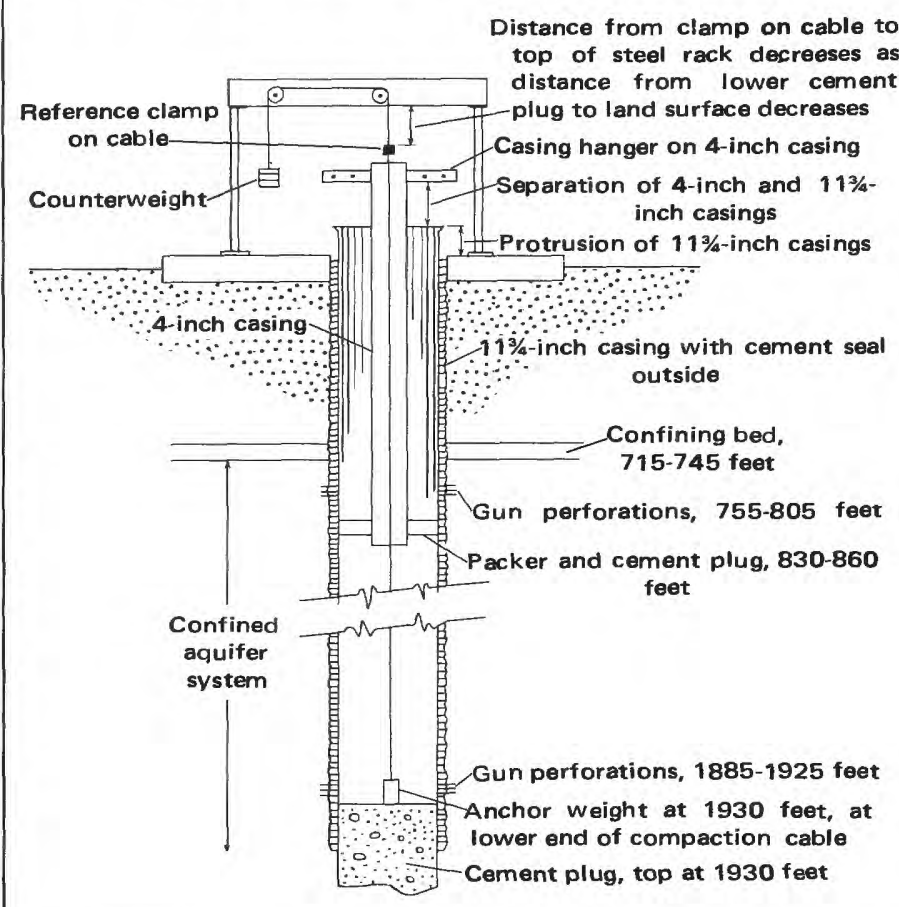

FIGURE 38.-Diagrammatic sketch of wells used for measuring water levels and compaction; wells 20/18-11Q2 and 11Q3. (From Poland and Ireland, 1965.) 


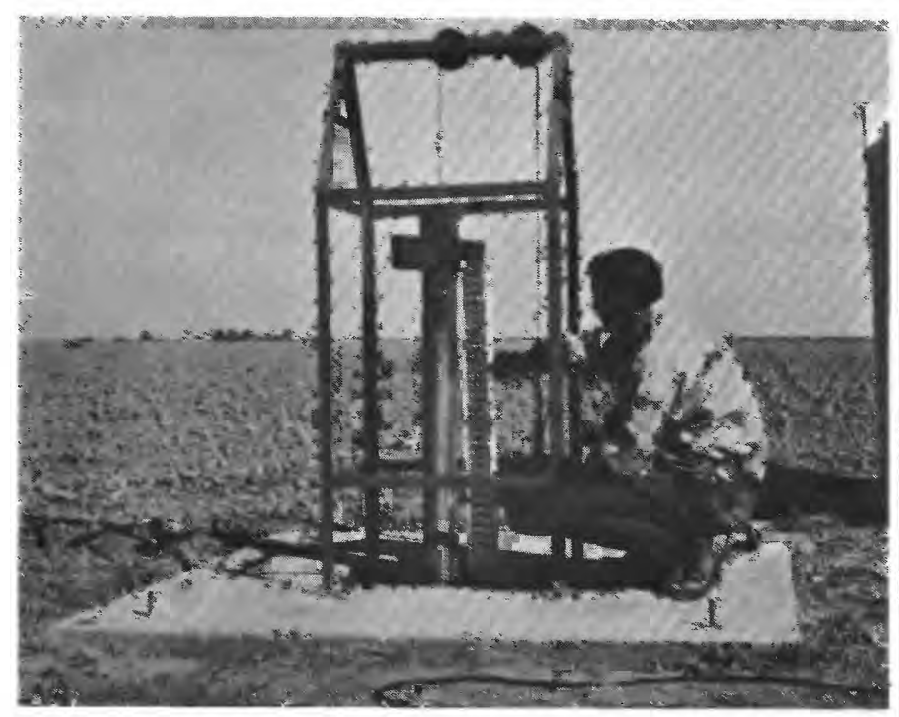

FIGURE 39. Compaction gage and casing separation at wells 20/18-11Q2 (inner casing) and 11Q3 (outer casing).

1,930 feet was measured by movement of the land surface relative to the reference clamp on the cable; it was equivalent to the amount of increased casing protrusion above the land surface added to the amount of casing shortening. The results are shown in figure 40 . The plot of increased protrusion shows a reversal of about 0.015 foot late in 1963. Most of the reversal was due to soil and lumber swell which raised the table that was used as a reference point to measure changes in the position of the top of the casing. A concrete pad was poured in May 1964, and reversals of increased casing protrusion have been minor since then.

Between August 1962 and October 1965, the total compaction above 1,930 feet was 1.98 feet. The total shortening of the 113/4-inch casing and its cement jacket from the land surface to a depth of 1,930 feet was 1.83 feet $(1.98 \mathrm{ft}$ minus $0.15 \mathrm{ft}$ of increased casing protrusion). Casing shortening was 0.92 foot in the 0-845-foot-depth interval (casing separation) and 0.91 foot in the 845-1,930-foot-depth interval (1.83 ft minus $0.92 \mathrm{ft}$ ). For the 3 -year record plotted in figure 40 , casing shortening was equal to 92 percent of the compaction. Roughly 95 percent of the subsidence is being measured by the 1,930-foot compaction recorder. (See end of section "Cumulative Compaction at Multiple CompactionRecorder Sites.")

The oil-well casing at 20/18-11Q3 had an increased protrusion equal to 8 percent of the measured compaction. Well 19/16-23P2 also is an abandoned oil test and has an increased protrusion equal to about 3 percent of the measured compaction. These values of increased protrusion are about the same as for water-well casings of similar diameter.
Shortening Of Water-Well Casings

The main effect of compaction on well casings in the Los Banos-Kettleman City area has been to shorten the casings; amounts of increased protrusion have been minor. In contrast, in at least one subsiding area, Mexico City, observed protrusion of water-well casings has been as much as 18 feet in response to subsidence of about the same magnitude (Poland and Davis, 1969, p. 227-228 and pl. 6), showing that under certain physical conditions, the friction between the compacting sediments and the well casing may not be sufficient to overcome the casing strength. However, in Mexico City, the observed protrusion of well casings almost as great as the total subsidence is believed to be due in part to the fact that wells are drilled using several casing sizes. The maximum protrusion is observed for inner casings separated from the formation for part of their length by outer casings of larger diameter.

General information about the shortening of waterwell casings in the Los Banos-Kettleman City area is available through bench-mark surveys made by the Coast and Geodetic Survey. During the mid-1950's, many well bench marks were established by chiseling a cross on top of the well casings or casing hangers of active and unused irrigation wells. For about 40 of these wells, reference bench marks consisting of a standard disk set in a concrete post were established within 0.1 mile of the wells.

It has been demonstrated that bench marks on well casings are not stable even though the casing may extend beneath the compacting sediments (Poland and Ireland, 1965). Also, increased protrusion of a casing above the land surface should not be considered a reliable measure of either land subsidence or compaction. The unreliability of well bench marks stems from the fact that the proportions of casing shortening and increased casing protrusion are unknown, unless detailed measurements are made such as were described for the Westhaven site.

Some useful generalities, however, can be made by comparing well bench marks and nearby reference bench marks. A comparison of 18 pairs of well and reference bench marks is shown in figure 41 . These selected pairs included only those pairs in which reference bench marks were 17-193 feet from the well bench marks, and excluded all those pairs of bench marks in near-surface subsidence areas. The surface casing diameter of the selected irrigation wells ranged from 12 to 20 inches. The periods between bench-mark surveys ranged from 2 to 9 years.

The comparison in figure 41 shows that the amounts of subsidence at the well and reference bench marks are not greatly different, as is shown by the way in which the points plot close to the line of equal subsidence for 


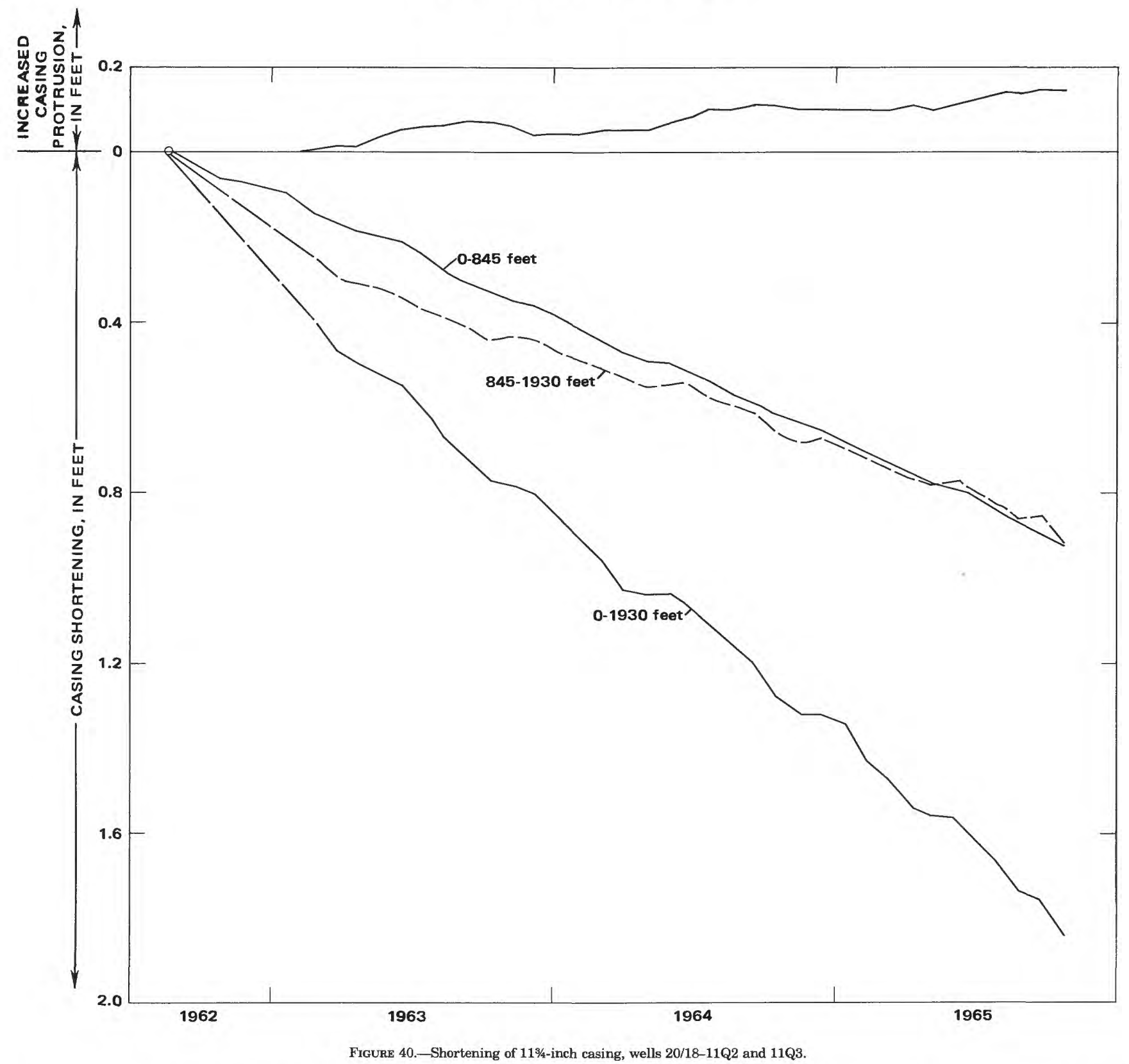

the two types of bench marks. From this can be stated that, in general, water-well casings in the Los Banos -Kettleman City area are being shortened in amounts roughly equal to the compaction of the deposits within the well depth.

The small amounts of increased casing protrusion make the measured amounts of subsidence at well bench marks less than the true amounts of subsidence. Where increased protrusion has occurred, all the points should plot below the line of equal subsidence in figure 41. Actually, 7 of the 18 points plot above the line, which means that some well bench marks subsided more than the reference bench marks despite the tendency of increased casing protrusion to reduce the amount of measured subsidence. Apparently, amounts of subsidence vary considerably for distances of less than 200 feet from wells.

The plot shown in figure 42 was made to determine whether the pumping of wells had any relation to the variation of subsidence measured at well and reference bench marks. The differences of subsidence between the two types of bench marks were as much as 9 percent. The differences are influenced to a small extent by the amounts of regional subsidence gradients between the two bench marks. However, the effect of regional subsidence trends probably is negligible for distances of 17-193 feet. In every case where the well was not pumped between levelings, the well bench mark sub- 


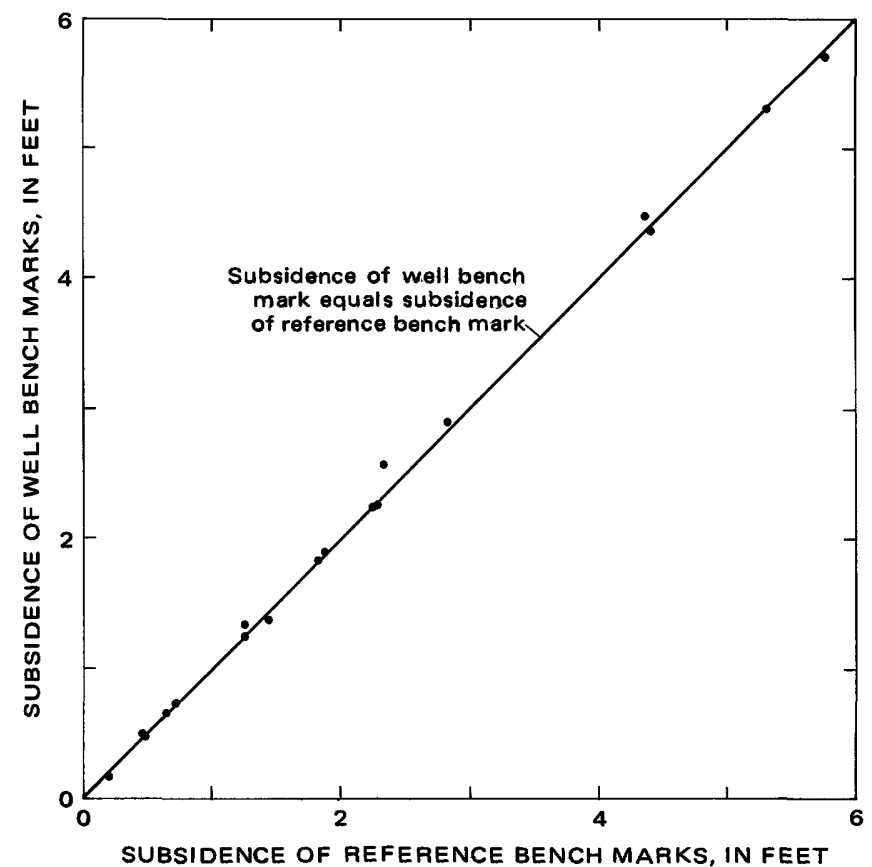

FIGURE 41.-Subsidence of well bench marks and reference bench marks within 17-193 feet of the well bench mark.

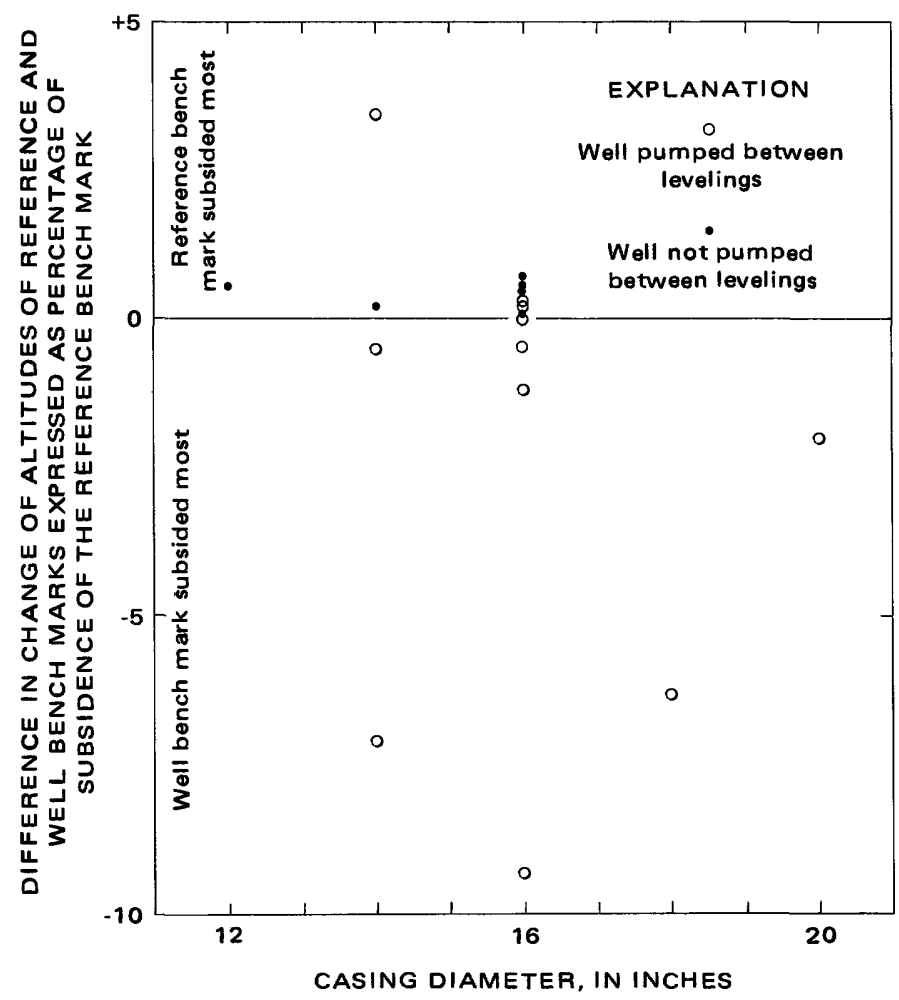

FIGURE 42.-Effect of pumping on differences of changes in altitudes of reference and well bench marks. $o=$ well pumped between levelings; $\bullet=$ well not pumped between levelings.

sided less than the reference bench mark. This can be explained in two ways: First, part of the compaction adjacent to the well casing results in increased casing protrusion instead of subsidence; second, if a well has become unused within the past few years, the applied stresses in the prior drawdown cone near the well may still exceed the maximum stresses that have been applied to the deposits beneath the reference bench mark. Where this situation exists, prior larger compaction amounts near the well may have made the deposits less susceptible to compaction, relative to the deposits beneath the reference bench mark, during the period between bench-mark surveys.

This evidence suggests that because the wells are point sources of maximum applied stress, maximum compaction occurs at or near the wells and that differences of subsidence between closely spaced bench marks near pumped wells should be expected. The magnitude of subsidence dimples around pumping wells should be larger than indicated in figure 42 because subsidence of well bench marks is reduced by any increased protrusion that has occurred. For several pairs of wells, the increased protrusion was sufficiently large that the subsidence of the well bench mark was less than subsidence of the reference bench mark, even though the well was pumped between bench-mark surveys.

\section{Casing-Failure Study}

Many of the water-well casings that are ruptured by compacting deposits are repaired. Before repairs are attempted, a survey of the damage to the well casing commonly is made with an underwater camera to locate the damage and to evaluate the feasibility of repairing the casing break. A photograph of a casing break is shown in figure 36. A study of the types, distribution, and relation of casing breaks to the adjacent deposits has been made by W. E. Wilson (written commun., April 1968 ) in about 650 square miles of the study area between townships 13 and 21 south. Selected parts of Wilson's work are included here and in the section "Geologic Factors Controlling Compaction of the Unconsolidated Deposits" because they provide information about compaction that cannot be obtained by compaction recorders.

Wilson's study included more than 1,100 reported casing failures in 275 irrigation wells. Most of the breaks were compressional types that resulted in the casing shortening. The data were obtained by the Laval Underground Surveys, Inc., and from pump company repair records.

The vertical distribution of casing failures with respect to the Corcoran Clay Member of the Tulare Formation is shown in figure 43 . All the casing breaks have been included, and the number of failures per 1,000 feet of well casing surveyed is plotted for each 50 -foot increment above and below the Corcoran. The unit casing- 


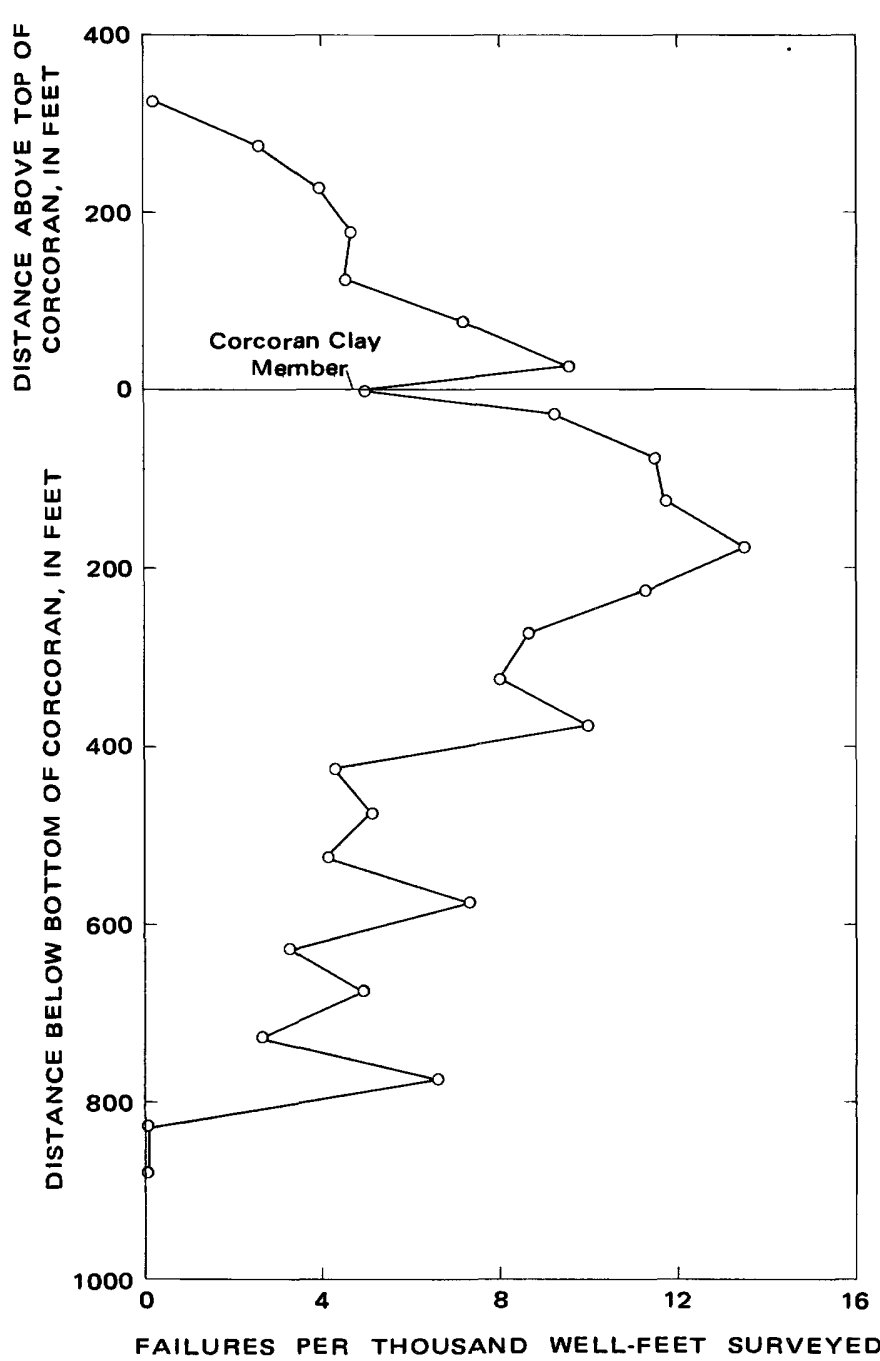

Figure 43.-Unit casing-failure ratio for 50 -foot intervals above and below the Corcoran Clay Member of the Tulare Formation. (From W. E. WiIson, written commun., April 1968).

failure ratio increases to a depth of about 200 feet below the bottom of the Corcoran. The depth to the base of the Corcoran within Wilson's study area ranged from 500 to more than 900 feet. Below a depth of about 200 feet below the bottom of the Corcoran, the values of unit casing-failure ratio decrease. Part of the fluctuation of the plot below a depth of 300 feet below the Corcoran probably can be attributed to the decrease in footage of well casing surveyed at the greater depths. Only 20 percent of the total footage of well casing surveyed was at depths of more than 300 feet below the bottom of the Corcoran (W. E. Wilson, written commun., April 1968).

The vertical distribution of unit casing-failure ratio permits some useful general conclusions regarding the variation of compaction with depth in the Los Banos -Kettleman City area, if one makes the assumption that casing failures are most common in depth intervals that are compacting the most. From 300 feet above the Corcoran to land surface (depth interval ranges of 0-100 to $0-600 \mathrm{ft}$ ), the sparseness of casing failures indicates that little compaction is occurring. Maximum unit compaction is suggested in the interval between 50 feet above the Corcoran and 250 feet below the Corcoran. The unit casing-failure ratio for this interval is about twice that of the deposits above and below the interval. The Corcoran has a unit casing-failure ratio of only 5 , indicating that the Corcoran either is not compacting as much as the deposits above and below it or that the clay does not grip the casing and gravel pack of the wells tightly enough to result in shortening of the casing equal to the shortening of the deposits of the Corcoran. The lower values of unit casing-failure occurrence below a depth of 400 feet below the bottom of the Corcoran suggest that deposits at these depths have a lower specific unit compaction than the deposits above them. Some reasons for the increasing and decreasing trends of unit casing-failure ratio are discussed in the section "Distribution of Well-Casing Failures."

Wilson found that the casing failures were most common in the areas that had subsided the most (W. E. Wilson, written commun., April 1968). A comparison of unit compaction at multiple compaction-recorder sites and unit casing-failure occurrences in the same depth intervals of nearby irrigation wells is shown in figure 44.

At the Mendota and Cantua sites, the variation in unit casing-failure ratio agrees very well with the variation in unit compaction for the same depth intervals. The agreement is not good at the Westhaven site. Casing failures are more common per unit well foot surveyed in the lower zone, yet figure 34 indicates that the upper zone has the largest unit compaction. One explanation for this apparent anomaly is that the lower-zone deposits may grip the well casings more tightly than the upper-zone deposits.

\section{PROPORTIONS OF COMPACTION OCCURRING IN THE UPPER AND LOWER ZONES}

General information about the proportions of compaction occurring in the upper and lower zones is available at 12 compaction-recorder sites in the Los Banos -Kettleman City area. The upper zone is 300-900 feet thick, and the lower zone is $400-2,400$ feet thick. The amounts of water pumped and the resulting compaction of the two zones vary greatly in the different parts of the area.

Most compaction-recorder wells do not have anchors set in the top of the Corcoran. The main purpose of the Bureau of Reclamation wells along the San Luis Canal was to monitor lower-zone head changes. In some cases, a suitable sand was not found within 200 feet of the bottom of the Corcoran. The main purpose of the Department of Water Resources wells at the Yearout, 

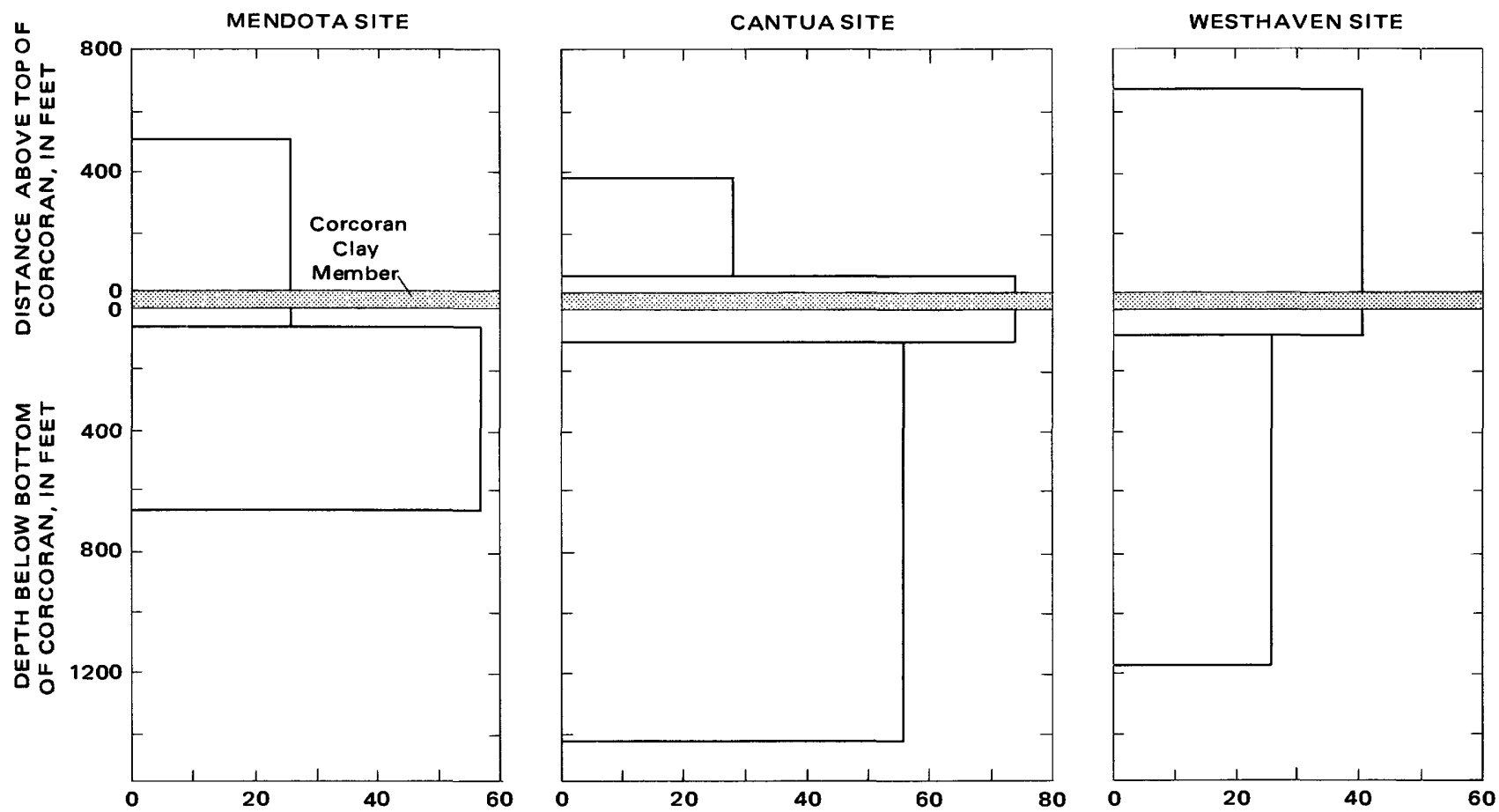

A. MEAN ANNUAL UNIT COMPACTION $\times 10,51963-65$, IN FEET PER FOOT
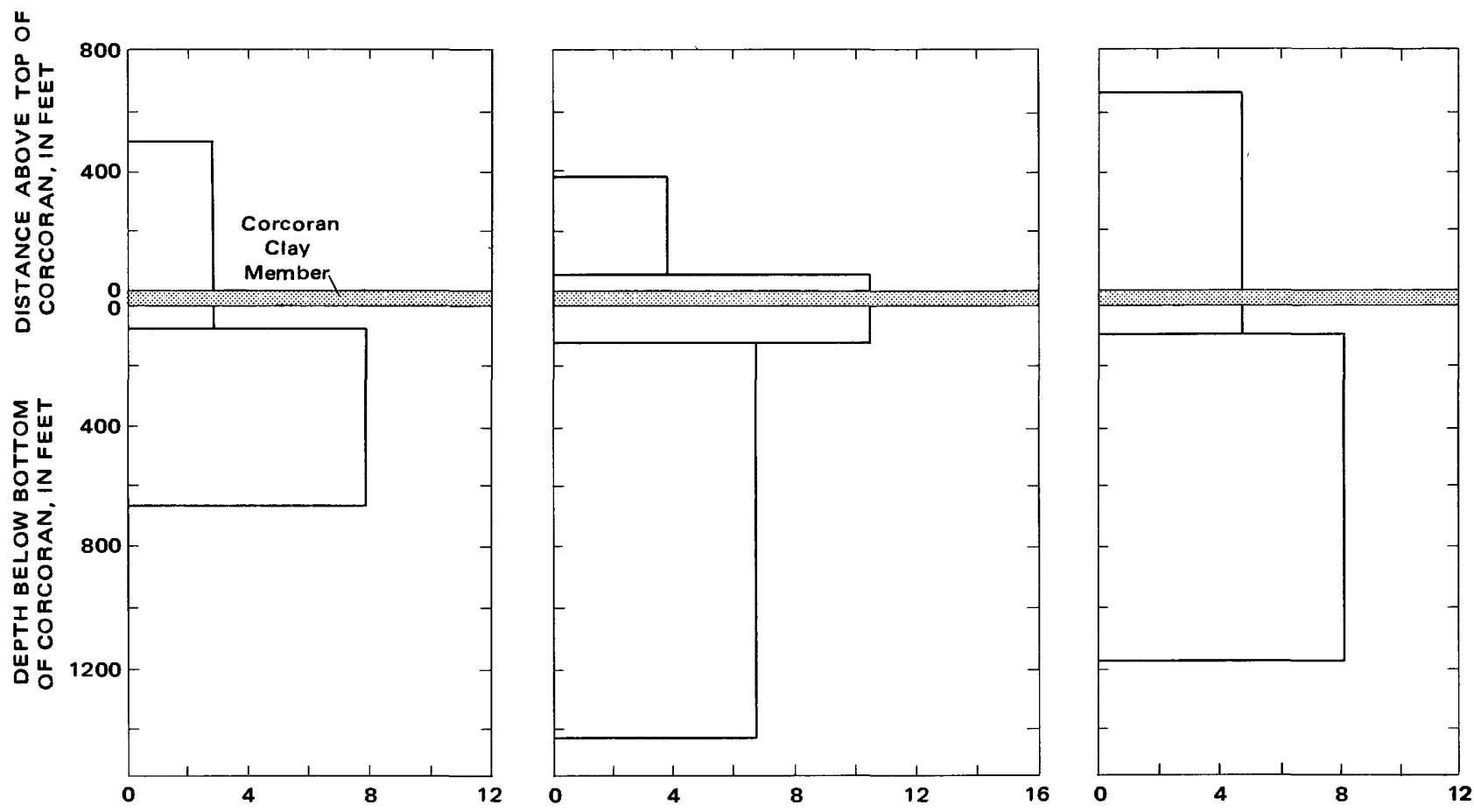

B. UNIT CASING-FAILURE RATIO, IN FAILURES PER 1,000 FEET

Figure 44.-Comparison of unit compaction at the Mendota, Cantua, and Westhaven sites and unit casing-failure ratios in the same depth intervals of nearby irrigation wells. A, Mean annual unit compaction, 1963-65. B, Variation of unit casing-failure ratio with depth. (From W. E. Wilson, written commun., April 1968.)

Tranquillity, and Lemoore sites was to determine the proportion of compaction occurring above and below the Corcoran. The compaction recorders at these sites have anchors set near the top of the Corcoran to measure shortening of the deposits between the land surface and the Corcoran. Total subsidence and lower-zone compaction are obtained as a result of periodic surveys of the bench marks at the sites. 
Estimates of the proportions of compaction occurring in the two zones are based on compaction-recorder data and bench-mark surveys. The proportions of subsidence in the two zones described in this section are based on information obtained since 1958 , but the proportions are generally applicable for pre- 1960 periods, such as the 1943-59 period, because the proportions of water pumped from the two zones in the different parts of the area (based on well-perforation data) have not changed greatly since 1943. Estimated proportions of the compaction occurring in the upper and lower zones are given in table 4 . The Corcoran has been included in the lower zone in this discussion.

Several correction procedures were necessary to compute the rough estimates because the compaction anchors were not set in the top of the Corcoran at most sites. Estimates at those sites where the well does not bottom near the top of the Corcoran may overestimate the proportion of upper-zone compaction by as much as 10 percent. Estimates of the unit compaction between an anchor and the top of the Corcoran were made as follows. At multiple compaction-recorder sites
$12 / 12-16 \mathrm{H}$ and $16 / 15-34 \mathrm{~N}$, the unit compaction was determined for the interval between the bench marks set above and below the Corcoran. At the single compaction sites where the anchor was set above or below the Corcoran, the unit compaction for the interval between the water table and the anchor was used to interpolate or extrapolate amounts of unit compaction in order to estimate the amount of compaction between the water table and the top of the Corcoran. Corrections based on these procedures provided estimates of the maximum proportion of compaction occurring above the Corcoran because values of unit compaction are larger for the lower zone than for the upper zone, except at the south end of the study area (figs. 33, 36).

The proportions of compaction in the upper and lower zones given in table 4 and shown in figure 45 indicate that, in general, north of Cantua Creek less than 20 percent of the compaction occurs in the upper zone, but south of Cantua Creek about 30-40 percent of compaction is occurring in the upper zone. Northeast of the town of Cantua Creek, most of the water is pumped from upper-zone aquifers, which in that area yield the best

TABLE 4.-Proportions of compaction occurring

\begin{tabular}{|c|c|c|c|c|c|}
\hline $\begin{array}{c}\begin{array}{c}\text { Period } \\
\text { of } \\
\text { measurement }\end{array}\end{array}$ & $\begin{array}{l}\text { Depth } \\
\text { interval } \\
\text { Corcoran } \\
\text { Clay } \\
\text { Member } \\
\text { (ft below } \\
\text { land surface) }\end{array}$ & $\begin{array}{l}\text { Anchor depth } \\
\text { when } \\
\text { installed } \\
\text { (ft below } \\
\text { land surface) }\end{array}$ & $\begin{array}{c}\text { Position } \\
\text { of anchor } \\
\text { above }(+) \\
\text { or } \\
\text { below (-) } \\
\text { top of } \\
\text { Corcoran Clay } \\
\text { Member }\end{array}$ & $\begin{array}{l}\text { Depth to } \\
\text { water } \\
\text { table, } \\
1965 \\
\text { (ft) }\end{array}$ & $\begin{array}{c}\begin{array}{c}\text { Compacting } \\
\text { interval } \\
\text { (ft) }\end{array} \\
\begin{array}{c}\text { Compacting } \\
\text { thickness } \\
\text { (ft) }\end{array}\end{array}$ \\
\hline $12 / 12-16 \mathrm{H} 3 \quad 10 / 61-10 / 65$ & 279465 & 250 & +29 & 10 & $10-350$ \\
\hline $12 / 12-10133-\ldots$ & $379-465$ & 500 & 121 & 10 & $\begin{array}{c}340 \\
350-500 \\
\end{array}$ \\
\hline $16 \mathrm{H} 4$ - $10 .-10 / 65$ & $379-465$ & 500 & -121 & 180 & $\begin{array}{c}150 \\
180-690 \\
\end{array}$ \\
\hline $13 / 12-20 \mathrm{D} 1$ _...-.- 3/66-11/67 & $304-418$ & 690 & -386 & 180 & $\begin{array}{c}510 \\
10-440\end{array}$ \\
\hline $13 / 15-35 D 5 \quad \ldots-\ldots-5 / 66-5 / 68$ & $428-476$ & 440 & -12 & 10 & $\begin{array}{c}430 \\
190-913\end{array}$ \\
\hline $14 / 12-12 \mathrm{H} 1$ - & $615-719$ & 913 & -298 & 190 & $\begin{array}{c}723 \\
120-780 \\
\end{array}$ \\
\hline 14/13-11D4 - & $625-700$ & 780 & -155 & 120 & $\begin{array}{c}660 \\
220-958\end{array}$ \\
\hline $\begin{array}{l}15 / 13-11 \mathrm{D} 2 \\
15 / 16-31 \mathrm{~N} 3\end{array}$ & $768-860$ & 958 & -190 & 220 & $\begin{array}{c}738 \\
15-596 \\
\end{array}$ \\
\hline $16 / 15-34 \mathrm{~N} 3$ - & $565-575$ & 503 & +62 & 190 & $\begin{array}{c}581 \\
190-503 \\
\end{array}$ \\
\hline $34 \mathrm{~N} 2 \quad 12 / 62-12 / 65$ & & 703 & 128 & & $\begin{array}{c}313 \\
503-703 \\
\end{array}$ \\
\hline $34 \mathrm{~N} 2-\ldots-1 / 62-12 / 65$ & $565-575$ & 703 & -138 & $-\ldots--$ & 200 \\
\hline $18 / 16-33 A 1$ & $781-805$ & 1,029 & -248 & 40 & $\frac{40-1,029}{989}$ \\
\hline $18 / 19-20 P 2$ & $567-634$ & 578 & -11 & 15 & $\frac{15-578}{563}$ \\
\hline 20/18-6D1 - & $811-820$ & 867 & -56 & 150 & $\frac{150-867}{717}$ \\
\hline $11 Q 1 \ldots \ldots+12 / 64-12 / 65$ & 715-745 & 710 & +5 & 60 & 650 \\
\hline
\end{tabular}


quality water. Pore-pressure decline occurs in the lower zone mainly as a result of extensive lower-zone pumping in the vicinity of Cantua Creek. Southeast of Mendota, saline waters occur in the upper zone but not in the lower zone, and the combined effects of lower-zone pumping and lower-zone head decline more than 5 miles to the southwest result in more than 90 percent of the compaction occurring in the lower zone. Within the Delta-Mendota Canal service area, the wells supplementing the surface-water imports pump mainly lower-zone water. In addition, part of the head decline results from intensive lower-zone pumping to the south. Large proportions of lower-zone compaction occur at both the Yearout and Lemoore sites despite heavy upper-zone pumping at both sites. The upper-zone deposits being affected by pore-pressure decline are only 200-350 feet thick and consist largely of sands which undergo little inelastic compaction (Pt. 3, Bull and Poland, 1974). At the Lemoore site, the fresh-water bearing deposits below the Corcoran are more than 800 feet thick; the lower-zone head decline to the west apparently has decreased artesian head at the site sufficiently to result in more than 80 percent of the compaction occurring in the lower zone.

\section{GEOLOGIC FACTORS INFLUENCING COMPACTION OF THE UNCONSOLIDATED DEPOSITS}

The geologic factors affecting compaction of unconsolidated deposits can be evaluated on a local or regional basis. Within the Los Banos-Kettleman City area, sufficient data are available to assess the effect of overburden load, petrology, and bedding at core-hole sites and to assess areally the effect of prior total applied stress, age of the deposits, mean lithology, and source and mode of deposition on the susceptibility of the deposits to compaction upon increase in applied stress caused by ground-water pumping.

\section{LOCAL RELATIONS \\ OVERBURDEN LOAD}

The prior effective load on a given deposit partly determines the amount it has compacted in the geologic past and the potential for future compaction. In general,

in the upper and lower water-bearing zones

\begin{tabular}{|c|c|c|c|c|c|}
\hline \multirow{2}{*}{$\begin{array}{l}\text { Measured } \\
\text { compaction } \\
\text { (ft) }\end{array}$} & \multirow{2}{*}{$\begin{array}{l}\text { Extrapolated } \\
\text { compaction } \\
\text { between } \\
\text { anchor } \\
\text { and } \\
\text { top of } \\
\text { Corcoran }\end{array}$} & \multirow{2}{*}{$\begin{array}{l}\text { Estimated } \\
\text { maximum } \\
\text { compaction } \\
\text { occurring } \\
\text { above } \\
\text { the } \\
\text { Corcoran }\end{array}$} & \multicolumn{2}{|c|}{$\begin{array}{l}\text { Subsidence } \\
\text { during } \\
\text { period } \\
\text { of } \\
\text { measurement } \\
\text { (ft) }\end{array}$} & \multirow{2}{*}{$\begin{array}{c}\text { Maximum } \\
\text { upper-zone } \\
\text { compaction } \\
\text { (percent) } \\
\text { Minimum } \\
\text { lower-zone } \\
\text { compaction } \\
\text { (percent) }\end{array}$} \\
\hline & & & $\begin{array}{l}\text { Bench-mark } \\
\text { surveys }\end{array}$ & $\begin{array}{l}\text { Estimated; } \\
\text { extrapolated } \\
\text { from 1963-66 } \\
\text { subsidence } \\
\text { map }\end{array}$ & \\
\hline 0.05 & 0.01 & 0.06 & 1.30 & ------- & $\frac{5}{95}$ \\
\hline .04 & ------- & $---1--$ & ------- & $\ldots \ldots$ & $-\ldots$ \\
\hline .16 & .12 & .04 & .29 & ----- & $\frac{14}{86}$ \\
\hline .03 & 0 & .03 & ------- & .48 & $\begin{array}{l}\frac{6}{94} \\
28\end{array}$ \\
\hline .48 & .20 & .28 & .99 & $----\cdots$ & $\begin{array}{l}72 \\
19\end{array}$ \\
\hline .52 & .12 & .40 & 2.14 & -.......- & 81 \\
\hline .16 & .04 & .12 & ------. & .90 & $\begin{array}{l}\frac{13}{87} \\
32\end{array}$ \\
\hline .20 & 0 & .20 & ---- & .63 & $\begin{array}{l}\frac{04}{68} \\
13\end{array}$ \\
\hline .26 & .14 & .40 & 3.15 & $-\cdots-$ & 87 \\
\hline .45 & ------- & $\ldots=---$ & $-\cdots---$ & - & 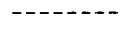 \\
\hline .33 & .08 & .25 & .56 & $-\ldots--$ & $\frac{45}{55}$ \\
\hline .07 & 0 & .07 & $\ldots-\ldots$ & .50 & $\begin{array}{l}\frac{14}{86} \\
33\end{array}$ \\
\hline .45 & .04 & .41 & 1.23 & ------- & 67 \\
\hline .25 & 0 & .25 & ----- & .60 & $\frac{42}{58}$ \\
\hline
\end{tabular}




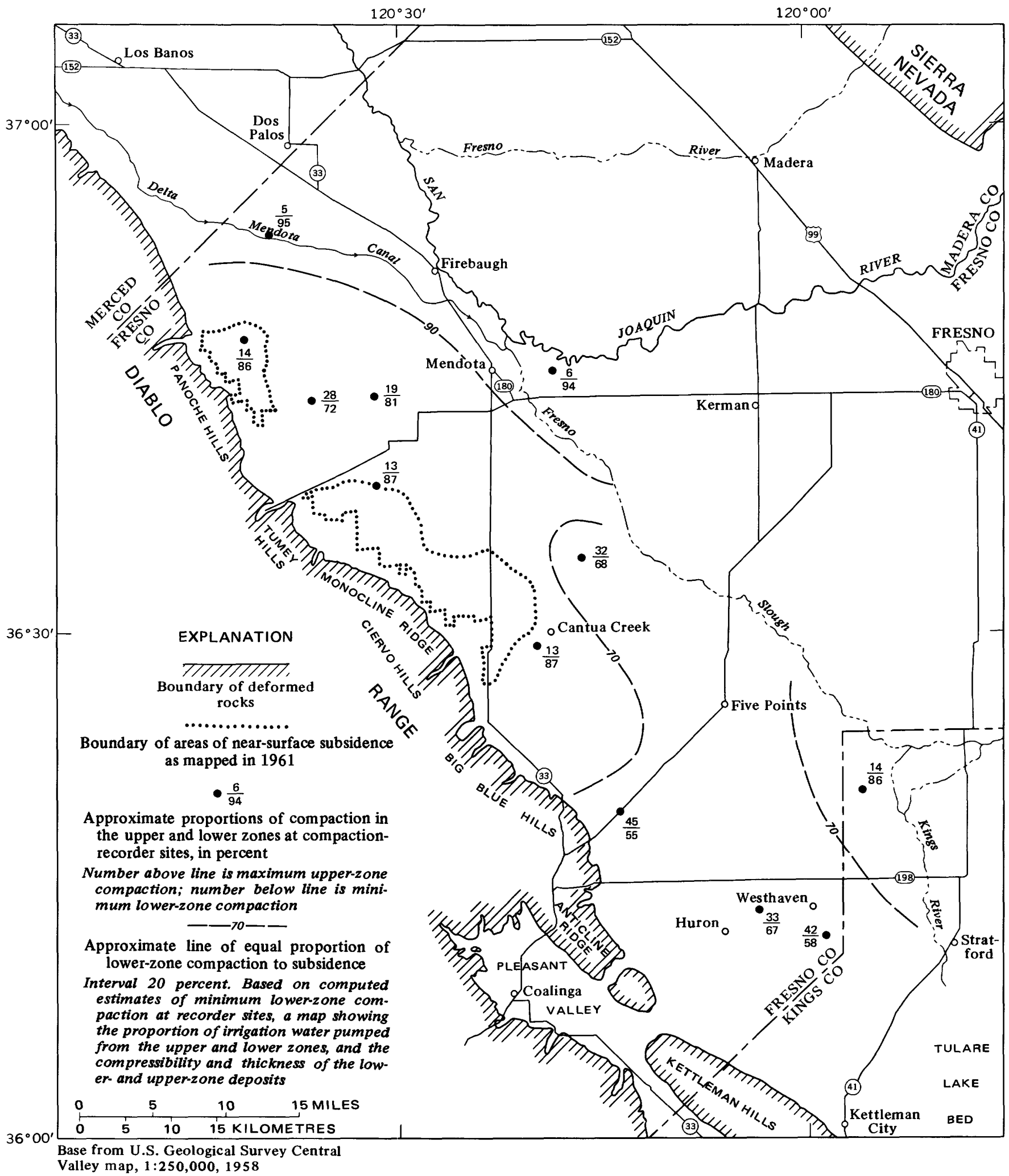

FIGURE 45.-Proportions of compaction occurring in the upper and lower water-bearing zones.

amounts of prior compaction increase with depth because prior applied stress increases with depth and because geologic time has been sufficient for applied stress increases to become effective, even in thick clay beds.
Several lines of evidence show that the compressibility of the deposits at the core-hole sites decreases with increasing depth of burial. Two examples of the decrease in compressibility with increasing effective 
stress at the Cantua site, derived from one-dimensional consolidation tests of core samples, are discussed in conjunction with figure 59.

The upper-zone deposits should be more compressible than the lower-zone deposits at the core-hole sites because they have been subjected to less prior effective stress. Petrologic characteristics greatly affect compressibility, but samples from the core-hole sites do not show major petrologic changes with depth of the deposits of a given source and depositional environment.

The relation between prior effective stress and compressibility of the deposits in the upper and lower zones probably explains the higher unit compaction in the upper zone at the Westhaven site (fig. 34). The bulk of the deposits in both zones at the Westhaven site consists of Diablo alluvial-fan deposits, with minor lacustrine deposits (Miller and others, 1971). Hydrographs of the wells at the site (Pt. 1, Bull and Miller, 1974, fig. 14) show that the history of head change at the base of the upper zone is about the same as that in wells tapping different parts of the lower zone. In addition, the casings of many of the irrigation wells in the vicinity of the Westhaven site are perforated for 100 feet or more above the Corcoran, indicating that withdrawal of ground water and head decline are common in the upper zone.

Specific unit compaction in the upper zone at the Oro Loma, Mendota, and Cantua sites also probably exceeds the lower-zone specific unit compaction at the sites, but is not apparent in figures 31-33. The total compaction for the upper zone at these three compaction-recorder sites probably is small because (1) the proportion of the upper-zone deposits affected by substantial head decline is much less than in the southern part of the study area and (2) the change in applied stress has not been as large as in the lower zone.

The factors affecting the relation between applied overburden load and unit compaction also are apparent in the plot of unit casing-failure ratio versus vertical distance from the Corcoran (fig. 43, and W. E. Wilson, written commun., April 1968). Unit casing-failure ratio increases to a depth of about 200 feet below the Corcoran and then decreases with increasing depth for the rest of the lower zone. Wilson's plot can be interpreted as follows if it is assumed that unit casing-failure ratio is related directly to the unit compaction of the adjacent deposits. For a given suite of deposits, unit compaction decreases with depth and increases with increasing pore-pressure decline. Pore-pressure decline is related directly to the amounts of water pumped from the deposits and hence to the perforated interval of the wells. Most of the wells are perforated mainly in the lower zone, and many of the wells that tap mainly the upper zone also tap the uppermost $100-300$ feet of the lower zone (Miller and others, 1971, pls. 3, 4). Wells that tap both zones are most common in the southeastern, eastern, and northern parts of the area. Thus, the pattern of unit casing-failure ratio shown in figure 43 is logical. The upper part of the plot reflects the dominance of progressively greater pumping of confined water to a depth of about 200 feet below the Corcoran. The lower part of the plot reflects dominance of the other component -decreasing compressibility of the deposits with depth because of the effect of the preexisting overburden loads and because of the moderately good hydraulic conductivity of the lower zone.

A detailed assessment of the properties of core samples from three sites in the Los Banos-Kettleman City area has been made by Meade (1968). Although the core samples reflect the selectivity of the coring process (more clays than sands are recovered), Meade's analysis provides a valuable insight into the factors influencing void ratio and porosity of sediments underlying areas of land subsidence.

The relation between the logarithm of applied stress at the time of coring and void ratio for 40 core samples consisting of clayey silt is shown in figure $46 A$. Meade segregated the cored alluvial sediments of the Los Banos-Kettleman City area into four lithologic groups to minimize the strong correlation between particle size and void ratio that also occurs in the suite of cores. The term "clayey silt" is based on Shepard's (1954) classification. The gap in the plot between applied stresses of 20 and 35 kilograms per square centimetre reflects the differential in artesian head across the Corcoran that exists in the northern and central parts of the area. The regression line shown in figure $46 A$ suggests that for the alluvial clayey silts cored, the void ratio would decrease from about 0.8 to 0.6 upon an increase in applied stress from 20 to 80 kilograms per square centimetre.

PETROLOGY

Laboratory consolidation tests made by many workers have shown that, in general, clays are much more compressible than sands. On the basis of the large body of literature discussing the result of laboratory studies, it is only natural to assume that conditions in the field consist of (1) small amounts of chiefly elastic compaction that occur rapidly in sands and (2) large amounts of chiefly inelastic compaction that occur slowly in clays.

These assumptions, although probably true in a general sense, have yet to be fully verified in the field. Furthermore, the state of knowledge about laboratory consolidation of sands is not nearly as well known as for clays because of the difficulty of fitting a sand sample into a consolidometer ring without disturbing the sample to the extent that results are unreliable. Most of the deposits in the study area consist of thin beds that 


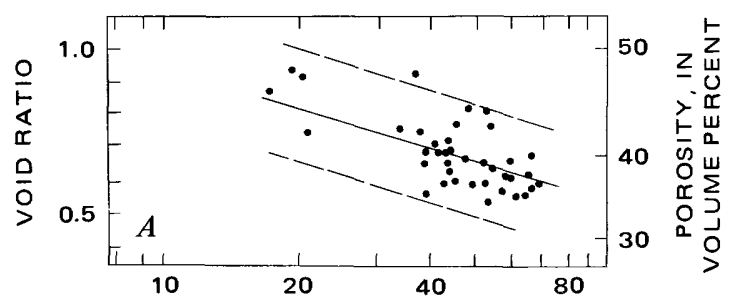

APPLIED STRESS, IN KILOGRAMS PER SQUARE CENTIMETRE
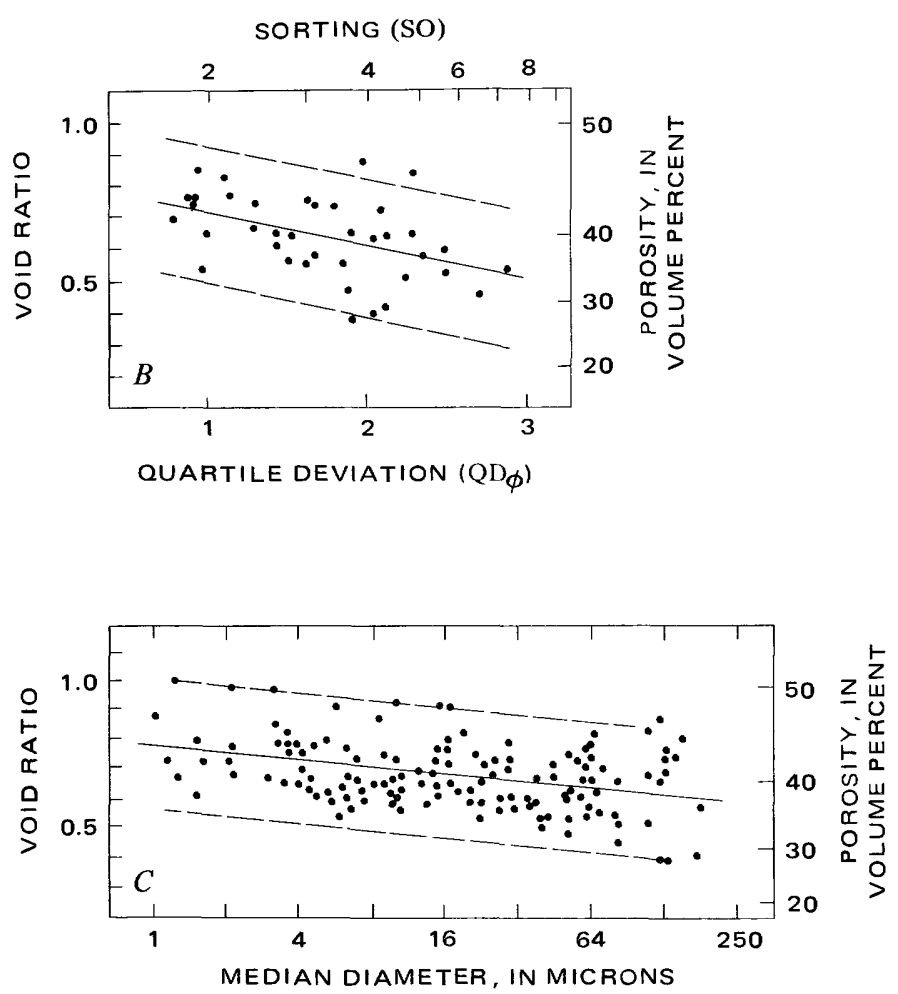

Figure 46.-Relation of applied stress, sorting, and particle size on void ratio and porosity of selected suites of samples of alluvial sediments from three core holes in the Los Banos -Kettleman City area. Figures are from Meade (1968, figs. 11C, 13A, 16); solid lines are the regression lines, dashed lines represent the 95 percent confidence limits. $A$, Relation between void ratio and applied stress for clayey silts. $B$, Relation between void ratio and quartile deviation $Q D_{\phi}=\frac{\phi_{25-\phi 75}}{2}$ in silty sands. $C$, Relation between void ratio and median particle diameter for all samples.

contain clay. Compaction recorders have measured net change in thickness of suites of deposits. None of the compaction recorders have been positioned in pairs so as to measure specifically changes in the thicker lacustrine silty clays and clayey silts such as the Corcoran. Because of the lack of quantitative information about the compaction of different lithologies in the field, many of the interpretations about compaction in subsidence areas are based on assumptions derived from laboratory investigations.

Compaction of sands occurs as a result of elastic compression of the grains and by rearrangement of the particles. Most of the laboratory studies about consolidation of sands have been made on clean quartz sands, and little work has been done on clayey sands, micaceous sands, and polymineralic sands. Meade (1968, p. 9-14) reviewed the work that has been done regarding the void ratio characteristics of sands. In brief, void ratio of sands decreases with increase in median diameter, decrease in sorting, decrease in the angularity of the grains, and increase in overburden load.

Consolidation characteristics of sands that contain mica flakes are different from mica-free sands. The mica flakes act as elastic beams between some of the sand grains. Studies by Gilboy (1928) showed that only a small percentage of mica added to a clean quartz sand greatly increases the compressibility of the sand.

The variable presence of mica in the sediments of the Los Banos-Kettleman City area may explain, in part, the variations in net specific unit expansion that have been observed at compaction-recorder sites. According to Meade (1967, p. 5), sands derived from the Sierra Nevada contain 2-5 percent of fresh-looking biotite in large flakes, and sands derived from the Diablo Range contain 2 percent or less of weathered-looking mica in small flakes.

In his study of the fabric of sands, Meade (1968, p. 32-34) concluded that distortion of compressible grains such as mica flakes and fragments of partly weathered shales and metamorphic rocks contributed to the compressibility of the sands represented by the core samples. He also concluded that the orientation of large mica flakes parallel to the bedding in the Sierra sands was more conducive to elastic changes in thickness of the deposits than the orientation of small mica flakes at roughly $45^{\circ}$ to the bedding in the Diablo sands. Large mica flakes oriented parallel to the bedding should respond to an increase in applied stress by bending around the grains - an elastic type of movement that is easily reversed upon decrease in applied stress. Small mica flakes oriented at $45^{\circ}$ to the bedding should respond to an increase in applied stress by allowing particles to slip past one another into a denser state of packing - an inelastic type of movement that is largely permanent. But, as Meade stated, the compressibility of both types of fabrics in micaceous sands provides a greater potential compressibility than in mica-free sands.

In general, silts are considered more compressible than sands, but not as compressible as clays, probably in part because the coarser silt fraction does not have sufficient surface area to absorb the large amounts of water typically absorbed by clays. Most well-sorted silts have larger void ratios than sands because of the greater angularity of individual grains. The poorer sorting of some silts, as compared with sands, tends to result in a lower void ratio. 
Detailed studies of the clay mineralogy of the sediments of 101 samples, 85 from deep core holes and 16 from streams and alluvial-fan deposits to a depth of 70 feet, have been made by Meade (1967, p. 18-24). There is a uniform preponderance of montmorillonite in the clay-mineral assemblages from the Sierra (derived from Sierra Nevada) as well as Diablo (derived from Diablo Range) source terranes. Calcium is the principal adsorbed cation in the clays. The percent of adsorbed sodium increases with depth, but does not exceed 38 percent of the cations in any of the samples tested.

From studies of samples from core holes at the Mendota, Cantua Creek, and Huron sites, Meade (1967, p. 22 , table 5) estimated that the amount of material finer than 3 micrometres represented the proportion of clay minerals in the cores. The mean of the material finer than 3 micrometres in the 305 core samples is 26 percent. The mean was adjusted by Meade $(1967$, p. 22$)$ to 15 percent, as an estimate of the proportion of clay minerals in the sediments, because the coring process tended to recover more clays than sands. However, the 3 -micrometre size is 1 micrometre smaller than the size generally recognized as being the size between clay- and silt-size material. Therefore, for purposes of general comparison in this paper, the mean percentages of material finer than 3 micrometres are considered to be roughly equivalent to the amount of clay-size material (less than 4 micrometres in the deposits at each site).

The amounts of clay-size particles in the deposits of different source areas and depositional types at the three core-hole sites are summarized in table 5. Cores from the Diablo flood-plain deposits have the lowest clay content ( 21 percent), and the Sierra deltaic deposits have the highest clay content (32 percent). The mean clay contents of all the cores from the Diablo and Sierra sources are about the same-27 percent for the Diablo deposits and 25 percent for the Sierra deposits. Almost

TABLE 5.-Amount of clay in deposits from Diablo and Sierra sources in the Mendota, Cantua, and Huron cores

\begin{tabular}{|c|c|c|}
\hline Source and mode of deposition ${ }^{1}$ & $\begin{array}{l}\text { Number of } \\
\text { samples }\end{array}$ & $\begin{array}{c}\text { Percent } \\
\text { finer than } \\
3 \text { micrometres } \\
\text { (mean) }\end{array}$ \\
\hline \multicolumn{3}{|l|}{ Diablo: } \\
\hline - - - - - - - - - & 145 & 28 \\
\hline Flood plain & 37 & 21 \\
\hline All Diablo samples & 182 & 27 \\
\hline \multicolumn{3}{|l|}{ Sierra: } \\
\hline Flood Plain & 58 & 23 \\
\hline Deltaic _... & 16 & 32 \\
\hline All Sierra samples _....... & 74 & 25 \\
\hline \multicolumn{3}{|l|}{ Combined Diablo and Sierra: } \\
\hline Lacustrine deposits & 44 & 27 \\
\hline All cored samples _. & ${ }^{3} 305$ & 26 \\
\hline
\end{tabular}

${ }^{1}$ From Miller, Green, and Davis (1971, pl. 5).

${ }^{2}$ Data from Meade (1967, table 5).

${ }^{3}$ Includes five samples for which the source and mode of deposition were not determined. half of the samples are Diablo alluvial-fan deposits, which have a mean clay content of 28 percent. The 44 core samples taken from the lacustrine sands and clays represent both Diablo and Sierra sources. The lacustrine deposits varied from clean littoral sands to silty clays; the mean clay content for the 44 samples was 27 percent.

The presence of clay adds greatly to the potential compressibility of the deposits of the study area. All clays tend to adsorb water, and the amount of water adsorbed is directly related to the surface area per unit volume of clay. Water farther away from the clay particles is not held as tightly as the water next to the clay minerals. Increase in applied stress removes the less tightly held water, causing a concurrent decrease in volume as water is expelled.

The rate of expulsion of water from aquitards and aquicludes is also a function of clay content. High clay contents tend to decrease the permeability and favor development of large residual excess pore pressures for a given applied-stress increase and bed thickness.

The fact that 7 parts out of 10 of the clay-mineral fraction consist of montmorillonite throughout nearly all the Los Banos-Kettleman City area is important. Because montmorillonite is very finely divided, it has a much larger specific surface than other clay minerals. Meade (1964, p. 6), in summarizing the studies of other workers, tabulated the following specific surface ranges in square metres per gram: montmorillonite, 600-800; illite, 65-100; and kaolinite, 5-30. Thus, montmorillonite can adsorb more water at a given applied stress and salinity than other clay minerals. This affinity for water permits montmorillonite to have a larger void ratio at a given effective stress than other clay minerals, and therefore more potential for compaction for a given increase in effective stress.

The void ratio of montmorillonite also is dependent, in part, on the electrolyte concentration and the nature of the adsorbed cations. Meade (1964, fig. 1), in his review of the literature concerning the clay-water system, pointed out that stronger osmotic pressures (and therefore larger void ratios) are associated with low electrolyte concentrations. He also pointed out (fig. 11) that at low effective stresses $\left(<10 \mathrm{~kg}\right.$ per $\left.\mathrm{cm}^{2}\right)$, montmorillonite saturated with sodium cations has a consistently larger void ratio than does montmorillonite saturated with calcium, magnesium, potassium, or alluminum cations. One would conclude, therefore, that the clayey deposits at shallow depth within the study area would be even more susceptible to compaction if the predominant adsorbed cation were sodium rather than calcium.

If the void ratio of a sample can be assumed to be a rough measure of potential compressibility, a strong 
correlation between potential compressibility and particle size can be demonstrated. Figure $46 C$ is a plot of the logarithm of median diameter and void ratio for 135 samples selected from alluvial deposits at the Mendota, Cantua, and Huron core holes. The semilogarithmic regression line suggests that the void ratio decreases from almost 0.8 for a median diameter of 1 micrometre to 0.6 for a median diameter of 250 micrometres.

Meade noted a significant simple correlation between void ratio and sorting of the cored sediments in the coarsest grained group of cores-the silty sands. The results of his regression analysis of void ratio and quartile sorting are shown in figure $46 B$. Meade $(1968$, p. 25) pointed out that the degree of sorting also decreases with depth, and so the regression reflects the effect of some other factor(s).

The combined effects of the many physical and chemical factors influencing compaction of clays is difficult to assess. In an important statistical study, Meade (1968) made a multiple-regression analysis from core studies of the Richgrove site in the southern San Joaquin Valley of the pore volume, overburden load, particle size, clay-mineral type, type of adsorbed cations, total dissolved solids in leachate, $\mathrm{pH}$, orientation of the montmorillonite flakes, and diatom content. He concluded that the effects of overburden load on the pore volume in the suite of sediments studied is completely obscured by petrologic factors, which were responsible for an increase of void ratio with inceasing depth. The pore volume was most closely related to particle size, diatom content, and the proportion of adsorbed sodium. Other factors thought to have a direct or indirect influence on pore volume were the dominant proportion of montmorillonite in the clay fraction, $\mathrm{pH}$, and electrolyte concentration.

Although a similar study has not been made in the Los Banos-Kettleman City area, it is anticipated that the petrologic factors having a dominant influence on pore volume will not be greatly different from those defined by Meade. For example, the diatomaceous clays of the Corcoran lacustrine sequence characteristically have the maximum void ratios and compressibilities.

\section{BEDDING}

The bedding of the deposits is one of the most important geologic factors affecting the rate of compaction of unconsolidated sediments upon increase in applied stress.

If one considers units that are 50 to more than 1,000 feet thick, a given type of deposit-such as the Diablo alluvial-fan deposits-is surprisingly homogeneous: vertical and lateral changes in lithology occur gradually for a given fan. However, if one considers units of only a few inches or feet thick, abrupt changes in lithology are characteristic of all genetic types of the deposits.
The interlayering of thin-bedded compressible finegrained sediments with permeable coarse-grained sediments has resulted in aquifer systems that compact rapidly and substantially in response to increase in applied stress. Variations from this typical condition occur within the study area. In those areas where most of the beds are consistently coarse grained, such as some sites near the Kings River, the values of specific unit compaction (fig. 54) are less than in the areas of heterogeneous interbedding, presumably because the coarsegrained sediments are less compressible than clayey sediments. In those areas where hundreds of feet of clayey deposits occur, such as northeast of the Big Blue Hills, the values of specific unit compaction also are smaller than in those deposits that have heterogeneous interbedding because the low vertical permeabilities of the thick clay beds result in slow compaction rates and small amounts of observed compaction.

The time, $t$, necessary for a specified percentage of compaction to be completed in a clay bed can be estimated from the following equation, which is based on the Terzaghi theory of consolidation (Terzaghi and Peck, 1948, p. 241):

where

$$
t=\frac{T h^{2}}{c_{v}}
$$

$T=$ a dimensionless time factor that varies nonlinearly with the percentage of compaction completed;

$h=$ the thickness, in feet, of the compacting layer. If it is being drained through both upper and lower surfaces, the half thickness is used;

$c_{v}=$ the consolidation coefficient, in square feet per year, which is determined as part of the one-dimensional consolidation test.

The Terzaghi equation illustrates the importance of the thickness of compressible clay beds on the amount of time necessary for compaction to occur. The time required for a stress to become effective varies directly as the square of the bed thickness. The variable thickness of the Corcoran within the study area can be used as an example to illustrate the importance of bed thickness. The Corcoran varies in thickness from less than 1 foot to more than 100 feet. Assuming homogeneity, that is the hydrologic properties are identical and that expulsion of pore water only occurs at the bottom, a 100 -foot thickness of the Corcoran would require 10,000 times as long to undergo a given specific unit compaction as would the 1-foot thickness. Even 15-foot-thick clay beds may have sufficient residual excess pore pressures that they continue to compact after water levels have risen more than 50 feet (Pt. 3, Bull and Poland, 1974).

Electric logs of the wells within the area provide a means of evaluating the characteristic bed thicknesses 
of the different types of deposits. An electric log is shown in figure 47, and micrologs are shown in figures 48-52.

An electric $\log$ of the upper-zone aquifer system at well 18/19-20P1 is shown in figure 47. Below a depth of 200 feet, the resistivity log reveals three thick clay beds at about 240 feet, 290 feet, and below 565 feet. Two of these clays have been shown to be of lacustrine origin (Croft, 1972), the deepest clay being the Corcoran. The rest of the section consists almost entirely of waterbearing sands. The resistivity log reveals only general information about the gross thicknesses of large units, but the spontaneous-potential log shows that many of the units that appear to be thick-bedded sands on the resistivity log contain beds of finer grained material, perhaps having lithologies such as silty sand or clayey sand.

The beds of low resistivity on the spontaneouspotential log produce a negative deflection instead of the positive deflection commonly noted because of the relation of the mud and formation resistivities at this site. At the bottom-hole temperature of $21^{\circ} \mathrm{C}(694 \mathrm{ft})$, the mud resistivity was $1.68 \mathrm{ohm}$-metres (ohm-metres ${ }^{2}$ per metre). Apparently, the mud had a much lower resistivity than the formation resistivity, hence the clays show as deflections to the left and the sands show as deflections to the right on the spontaneous-potential log. In many of the electric-log surveys made in the study area, ground water is used to mix the mud, and as a result the resistivity contrast between the mud and the formation is so slight that the spontaneouspotential log is virtually useless. Salt is added sometimes to the drilling mud to produce a spontaneouspotential $\log$ with characteristics similar to the $\log$ shown in figure 47 .

The spontaneous-potential log of figure 47 shows that many of the beds in the Sierra flood-plain deposits between depths of 300 and 500 feet have the following thickness characteristics. Most of the sand beds are thick bedded, being 10-30 feet thick. Within the sand sequences are beds that are interpreted as being clayey or silty sand and, in general, are less than 10 feet thick.

Above a depth of 230 feet, the minute crenulations in the spontaneous-potential log suggest that the deposits are much more heterogeneous than the deposits in the depth interval from 300 to 550 feet. The deposits in the upper part of the log are interpreted as being alluvialfan deposits derived from the Diablo Range such as those noted in nearby core holes.

Detailed bedding of five different types of Sierra and Diablo deposits is shown in the micrologs (microinverse $\left.1^{\prime \prime} \times 1^{\prime \prime} \operatorname{logs}\right)$ of figures 48-52. The figures represent selected parts from logs made in the Inter-Agency Committee core holes at the Mendota, Cantua, and Huron sites. Samples from the intervals shown have
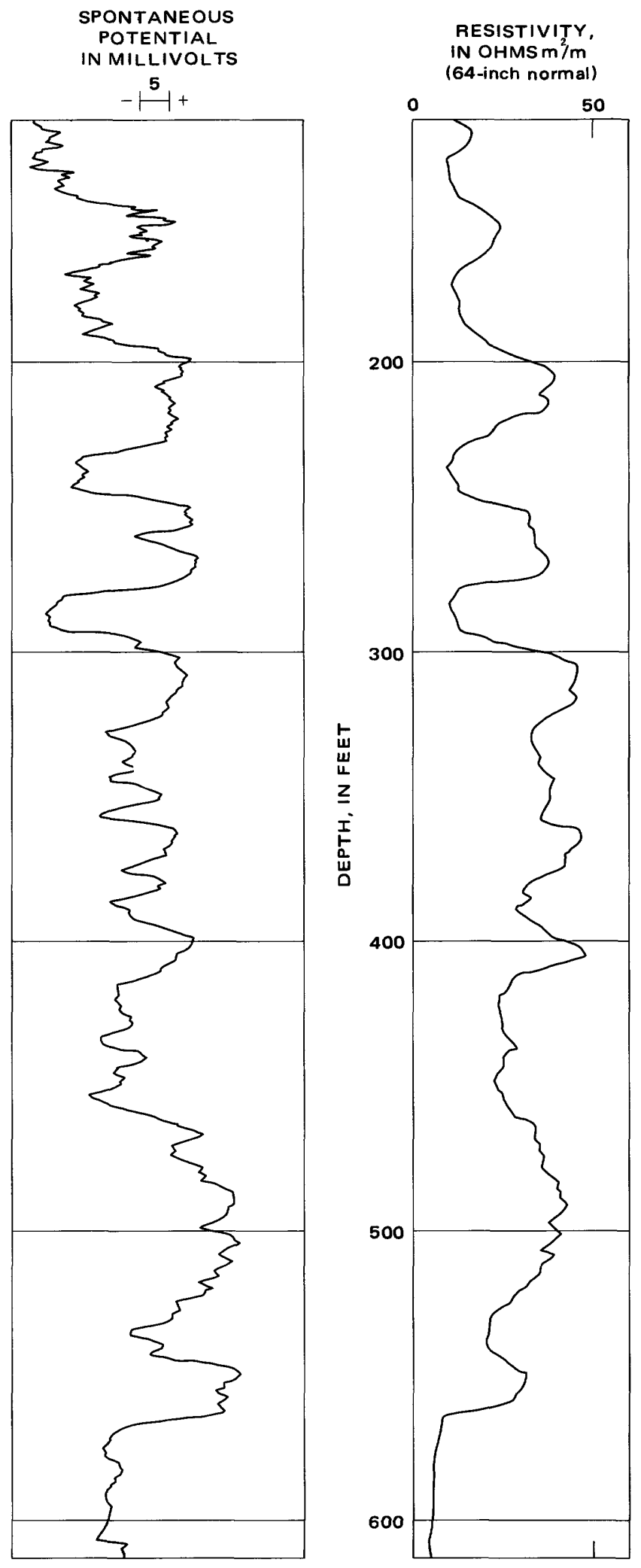

Figure 47--Electric log of the deposits at well 18/19-20P1.

been studied petrographically by Meade (1967), and the genetic types of deposits have been correlated on a re- 
gional basis by Miller (Miller and others, 1971). The resistivities of the logs have not been corrected to a common salinity and temperature. The percent of clay-mineral material is from Meade (1967, table 5), and the percentage of sand and vertical permeabilities are from Johnson, Moston, and Morris (1968). The solid arrows represent the reported depths from which the samples were collected. Discrepancies between the reported depths and the microlog depths, in general, are less than 2 feet. For many of the depths reported in the field, the position of the sample had to be estimated because 100 percent recovery was not obtained in many of the cores. Where discrepancies in depth are apparent, a dotted arrow has been added to indicate the bed from which the author believes the sample was obtained.

The coefficients of vertical permeability for clayey sediments with permeabilities of less than $0.01 \mathrm{gal}$ day $^{-1} \mathrm{ft}^{-2}$ (gallon per day per square foot) obtained from a variable head permeameter are considerably higher than permeabilities obtained from consolidation-test data of adjacent core samples. The differences are due in part to the unloaded condition and the use of water of different chemical character from the pore water in the permeameter tests (Johnson and others, 1968, p. 26). Therefore, the permeability results shown in figures 48-52 that are less than 0.01 gal day $^{-1}$ per $\mathrm{ft}^{-2}$ probably are higher than if the permeabilities had been computed from a time-consolidation test.

To provide the reader a rough comparison of the vertical permeabilities of the finer grained beds from the various types of deposits, mean permeabilities from 27 consolidation tests are shown in table 6. Only results obtained from samples tested in the load range 400-800 $\mathrm{lb}$ in $^{-2}$ (pounds per square inch) were used. The mean vertical permeabilities shown in table 6 indicate that fine-grained lithologies from both the lacustrine and alluvial-fan deposits have low permeabilities compared with the flood-plain deposits. The Diablo flood-plain deposits had the highest mean permeability, which is

TABLE 6. - Mean vertical permeabilities of the different types of deposits as determined from consolidation tests of samples in the load range 400-800 $\mathrm{lb}_{\mathrm{in}}^{-2}$ at the four core-hole sites

\begin{tabular}{|c|c|c|c|}
\hline \multirow[b]{2}{*}{ Source and mode of deposition ${ }^{1}$} & \multirow{2}{*}{$\begin{array}{c}\text { Number } \\
\text { of } \\
\text { tests }\end{array}$} & \multicolumn{2}{|c|}{ Mean coefficient of permeability ${ }^{2}$} \\
\hline & & $\begin{array}{l}\text { (gal day } y^{-1} \\
\left.\mathrm{ft}^{-2} \times 10^{-5}\right)\end{array}$ & (ft day $\left.{ }^{-1} \times 10^{-6}\right)$ \\
\hline \multicolumn{4}{|l|}{ Diablo: } \\
\hline Alluvial fan & -10 & 1.7 & 2.3 \\
\hline Flood plain & 9 & 5.7 & 7.6 \\
\hline \multicolumn{4}{|l|}{ Sierra: } \\
\hline Flood plain & 4 & 4.0 & 5.3 \\
\hline Combined Diablo and Sierra: & & & \\
\hline Lacustrine & 5 & 2.9 & 3.9 \\
\hline
\end{tabular}

1From Miller,Green, and Davis (1971, pl. 5).

${ }^{2}$ Data from table 9, Johnson, Moston, and Morris (1968, p. 64, 65). Cubic feet times 7.48 equals gallons. consistent with the high silt content and low clay content of these deposits as compared with the fine-grained beds of the other types of deposits.

The performance characteristics of the wells in the northern and southern parts of the study area indicate that major differences exist between the transmissivities of the flood-plain and alluvial-fan deposits. Most of the wells are designed and pumped in such a manner as to yield $1,000-1,500$ gallons per minute. In the northern area (such as T. 13 S., R. 13 E.), only $600-1,000$ feet of perforated interval are needed to get sufficient yields, and seasonal lowering of the potentiometric level is only 40-60 feet. In contrast, wells in the southern area (such as T. $20 \mathrm{~S}$., R. $18 \mathrm{E}$.) have perforated intervals of $1,200-1,600$ feet, and the seasonal lowering of the potentiometric level exceeds 100 feet. Comparison of yield factors of lower-zone wells tapping different types of deposits indicates that the flood-plain deposits are three to five times as permeable as the alluvial-fan deposits.

Sierra Flood-Plain Deposits

Bedding of the Sierra flood-plain deposits at the Cantua site is shown in figure 48 . The sand beds are

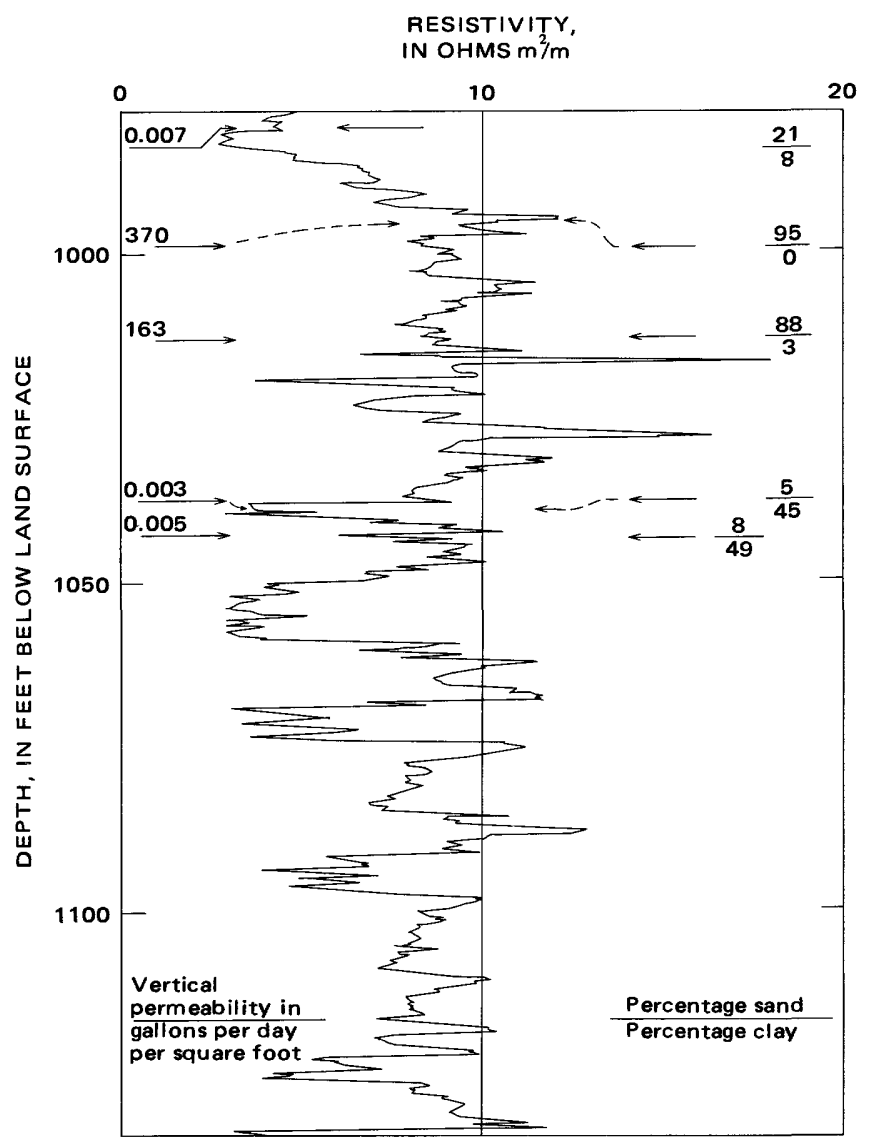

FIGURE 48.-Bedding, lithology, and vertical permeability of the Sierra flood-plain deposits, Cantua site, depth 978-1,134 feet. 
thick. A 65 -foot-thick sand section occurs between depths of 985 and 1,050 feet, but within the bed are two thin beds of fine-grained material -one that is 1 foot thick and one that is 2 feet thick. Despite the large thickness of the overall bed, numerous thin beds having resistivities in excess of $10 \mathrm{ohm}$-metres are common, indicating the presence of many beds that are coarser grained, or have lower clay contents than most of the sand section. The lower part of the log also reveals sand beds ranging in thickness from 10 to 30 feet. Beds of fine grained material as much as 9 feet thick occur also. The lithology of the finer grained units is not uniform, but instead consists of alternating beds of different lithologies that have a mean bed thickness of about 1 foot.

The lithologies of the Sierra flood-plain deposits have a wide range of particle-size distribution. The sand beds consist of about 90 percent sand, with virtually no clay. The fine-grained beds consist of almost half clay with less than 10 percent sand. The sample from a depth of 981 feet was well sorted even though it contained 70 percent silt.

$$
\text { Diablo'Alluvial-Fan Deposits }
$$

Bedding of the Diablo alluvial-fan deposits at the Mendota site is shown in figure 49. The bedding of the fan deposits is highly variable. Characteristically, the sand sections do not exceed 20-30 feet, and sand beds that are thicker than 10 feet appear to be less uniform in lithology than the Sierra sands. Sands predominate in the Sierra flood-plain deposits, but fine-grained deposits predominate in the Diablo alluvial-fan deposits. The finer grained sections of the alluvial-fan deposits range in thickness from less than 1 foot to more than 50 feet, but like the fine-grained sections of the Sierra flood-plain deposits, considerable lithologic variation of individual beds occurs.

The particle-size analyses indicate marked differences between the Sierra flood-plain deposits and the Diablo alluvial-fan deposits. Instead of containing 90 percent sand, the sand beds of the fan deposits contain 40-60 percent sand, and the clay content of the sand beds is 10-20 percent, instead of being less than 10 percent as in the case of the Sierra sands. Similar percentages of sand and clay occur in the thick sequences of alluvial-fan deposits in the southern part of the Los Banos-Kettleman City area. The sands of the Diablo alluvial-fan deposits at the Huron site rarely contain more than 60 percent sand and generally have 6-20 percent clay (Johnson and others, 1968, table 4).

The fine-grained beds in the alluvial-fan deposits contain large amounts of clay. The clay content of 61 percent for the sample at the 397 -foot depth in figure 49 was the maximum noted for the samples taken from fan

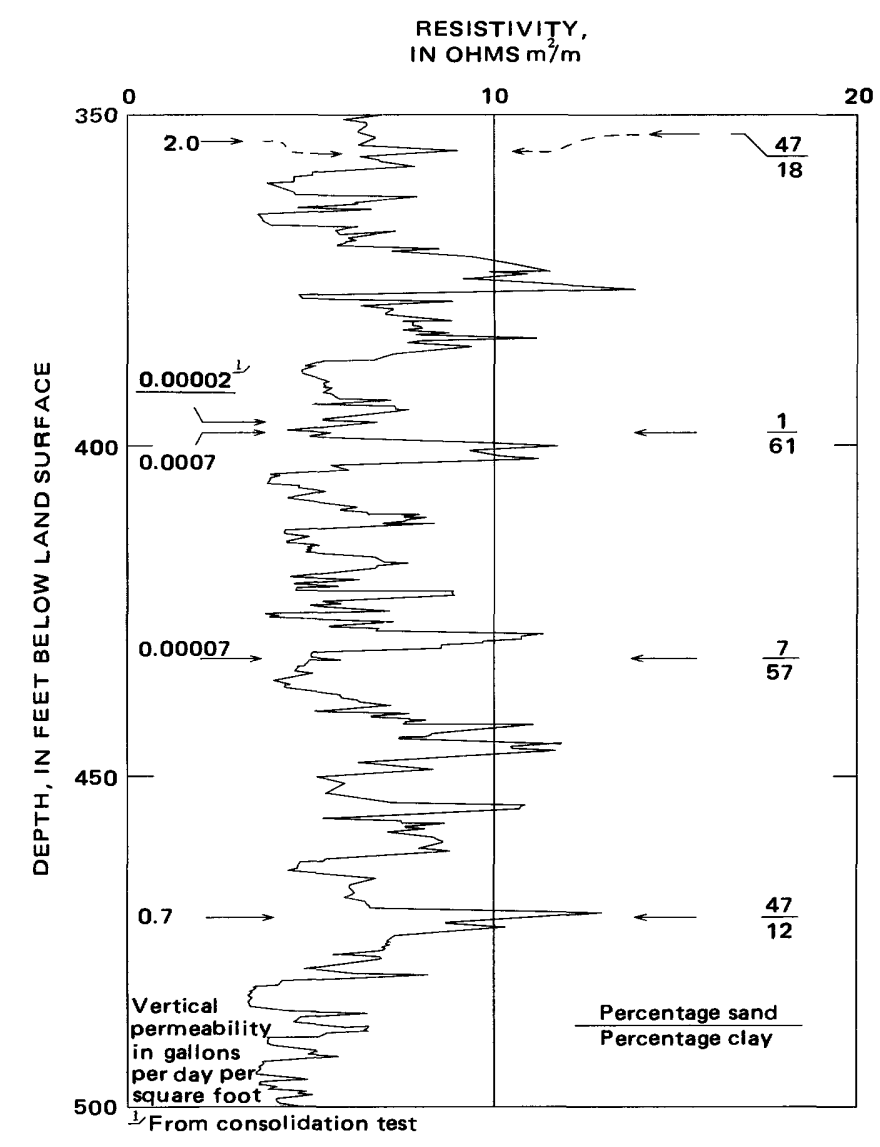

FIGURE 49.-Bedding, lithology, and vertical permeability of the Diablo alluvial-fan deposits, Mendota site, depth 350-500 feet.

deposits in the upper 600 feet. Clay contents in the $30-50$ percent range in the finer grained beds at both the Mendota and Huron sites are more common than clay contents of more than 50 percent.

The coarse-grained Diablo fan deposits are less permeable than the coarse-grained Sierra flood-plain deposits. The effect of the generally poor sorting of the fan deposits (Meade, 1967, fig. 12) tends to make the sand beds of the fan deposits have moderate to low permeabilities. For example, the sample from a depth of 472 feet in figure 49 contained 47 percent sand, but had a vertical permeability of only $0.7 \mathrm{gal} \mathrm{day}^{-1} \mathrm{ft}^{-2}$.

The minimum permeability measured (in a permeameter) in samples from the fine-grained beds in the fan deposits at the Mendota site was $7 \times 10^{-5}$ gal day $^{-1}$ $\mathrm{ft}^{-2}$.

\section{Diablo Flood-Plain Deposits}

Bedding of the Diablo flood-plain deposits at the Mendota site is shown in figure 50. The Diablo flood-plain deposits have abundant thin clayey and sandy beds. Characteristically, 4-8-foot-thick beds of clayey materials are interbedded with sand beds that range in thickness from less than 10 feet to more than 50 feet. The electric logs indicate that more abrupt 


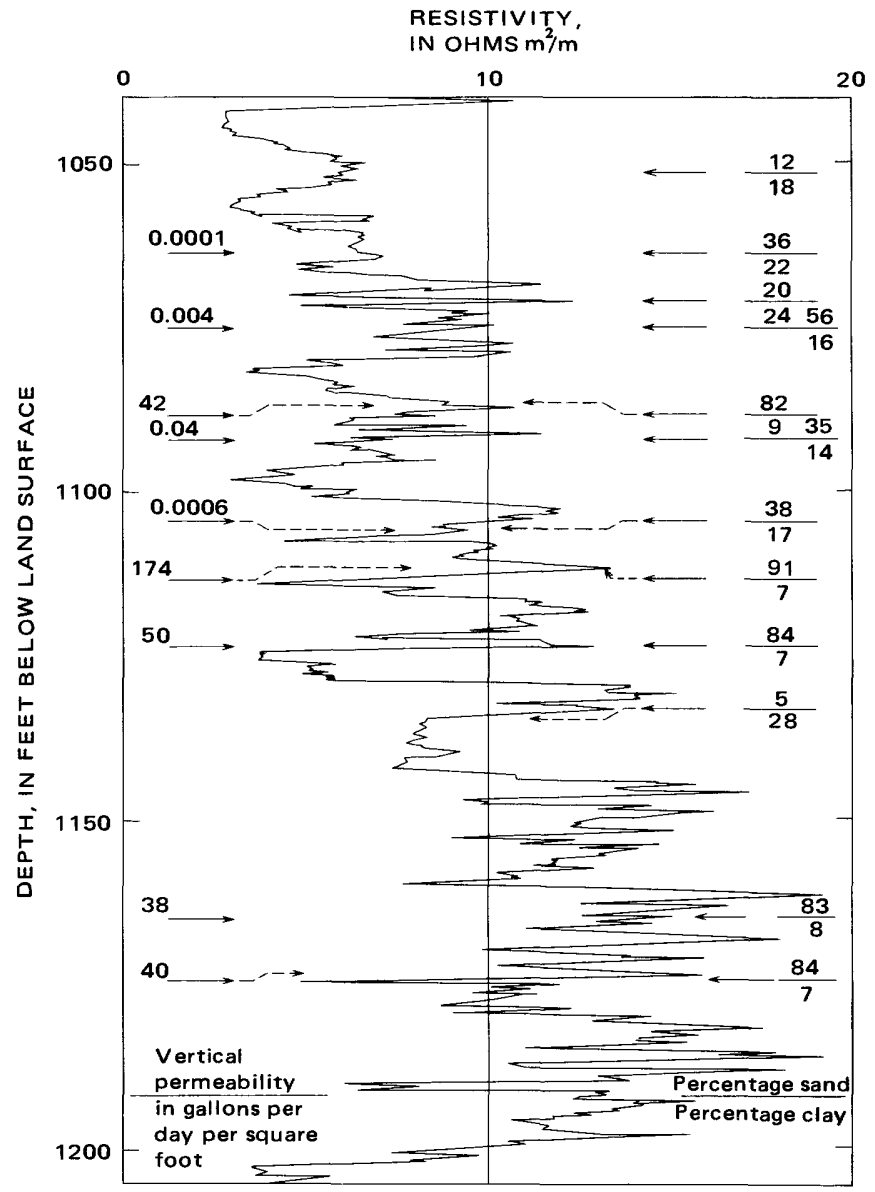

FIGURE 50.-Bedding, lithology, and vertical permeability of the Diablo flood-plain deposits, Mendota site, depth 1,040-1,205 feet.

changes in lithology occur in the Diablo flood-plain deposits than in the other types of deposits. Thin beds of clayey and silty materials within the thicker sand sections are much more common than in the Sierra flood-plain deposits, and the sand beds within the sand sections appear to be more variable in lithology than those in the Sierra flood-plain deposits.

The lithology of the sand beds appears to be that of clean sands, as in the case of the Sierra flood-plain deposits. In many of the sand beds, the amount of sand-size material ranges between 80 and 90 percent, and the amount of clay minerals is less than 10 percent. Only one sample from a fine-grained bed had a clay content of more than 36 percent, and the maximum clay contents for most of the fine-grained beds were about 20-30 percent. However, the fine-grained beds do contain large amounts of silt. Half of the beds sampled (fig. 52) had silt contents between 40 and 68 percent.

The laboratory permeabilities of the Diablo flood-plain deposits also are different from those for the other types of deposits. For the sand beds, the permeabilities appear to vary with the degree of sorting. Well sorted beds have moderate permeabilities, but sand beds that contain more than 15 percent silt and clay tend to have moderate to low permeabilities. Three sand beds that contained 72-76 percent sand had vertical permeabilities of only $1-2$ gal day $^{-1} \mathrm{ft}^{-2}$. The mean permeability of the fine-grained beds is three times the mean permeability of the more clayey Diablo alluvial-fan deposits (tables 5,6).

\section{Sierra Deltaic Deposits}

Beds that are considered to be deltaic deposits (Miller and others, 1971) derived from the Sierra Nevada are shown in figure 51. The bedding of the fine-grained deltaic deposits at the Huron site is distinctive when compared with the bedding of the other types of deposits. Thick beds of a dominant lithology do not occur; instead, alternating beds of silty clay and clayey silt seem to be typical of the Sierra deltaic deposits at this site. Between depths of 2,000 and 2,075 feet, the mean bed thickness is about 4 feet, but below 2,075 feet, the mean bed thickness is only 1 foot.

To the east of the Huron site, the deltaic beds consist of thick bedded crossbedded micaceous arkosic sand (Miller and others, p. 107). The coarse-grained facies of the deltaic deposits is similar to the Sierra flood-plain deposits in that thick sand beds characterize much of the section.

Most of the cores of deltaic deposits at the Huron site have less than 20 percent sand and 15-60 percent clay. The typical lithology of the cores is that of poorly sorted

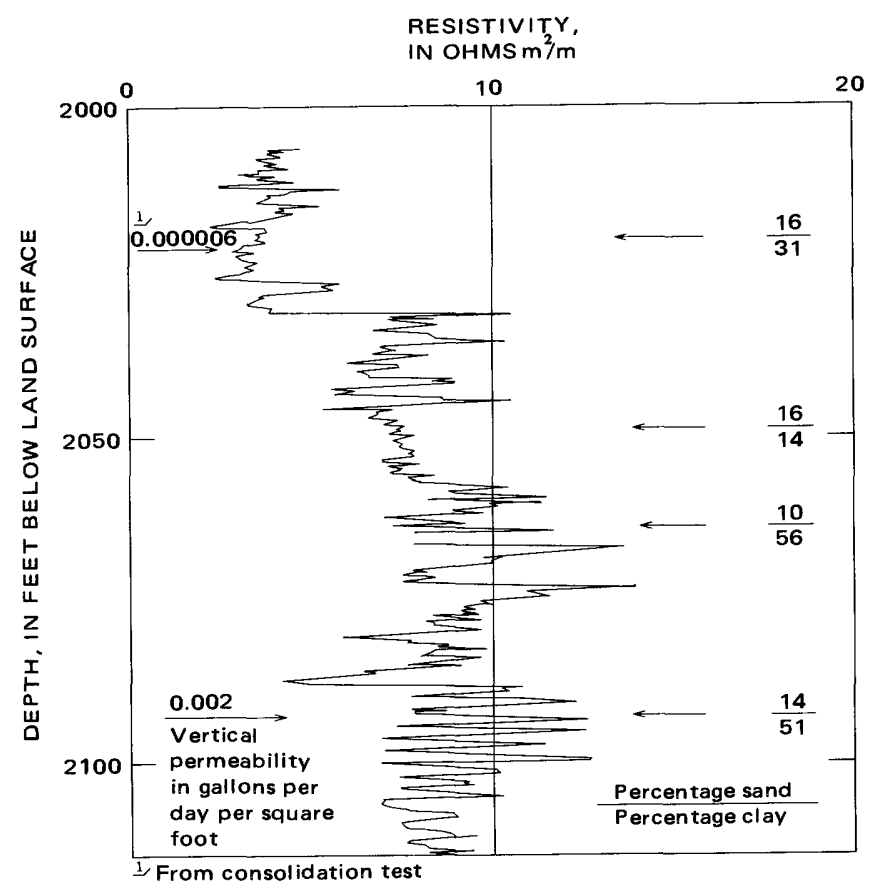

FIGURE 51.-Bedding, lithology, and vertical permeability of the fine-grained facies of the Sierra deltaic deposits, Huron site, depth $2,000-2,114$ feet. 
mixtures of sand, silt, and clay. Most of the sand sections were not recovered during coring.

The permeabilities of both the silty clay beds and the clayey silt beds is low. For the five samples tested in a permeameter, the range in permeability was from $4 \times 10^{-4}$ to $3 \times 10^{-2}$ gal day $^{-1} \mathrm{ft}^{-2}$. The mean of two permeabilities derived from consolidation tests in the $800-1,600-\mathrm{lb}$ in $^{-2}$ load range was about $1 \times 10^{-6}$ gal day $^{-1} \mathrm{ft}^{-2}$.

\section{LaCuSTRINe Deposits}

A microlog of the Corcoran Clay Member of the Tulare Formation at the Mendota site is shown in figure 52. Cores indicate that the Corcoran occurs between depths of 625 and 700 feet and that it is underlain by Sierra flood-plain deposits and overlain by Diablo flood-plain deposits. The 6 -foot sand beds that occur immediately above and below the Corcoran may be equivalent to thicker lacustrine sands that Miller (Miller and others, 1971) found associated with the Corcoran south of the Mendota site.

The bedding of the Corcoran is closer to being massive than any of the other types of deposits. The lower 20 feet of the Corcoran is distinctly coarser grained and of more uniform lithology than the upper $\mathbf{5 5}$ feet, as is indicated by both the electric and core logs. The coarser grained basal part is typical of the Corcoran throughout the study area. The typical sequence of the upper part is

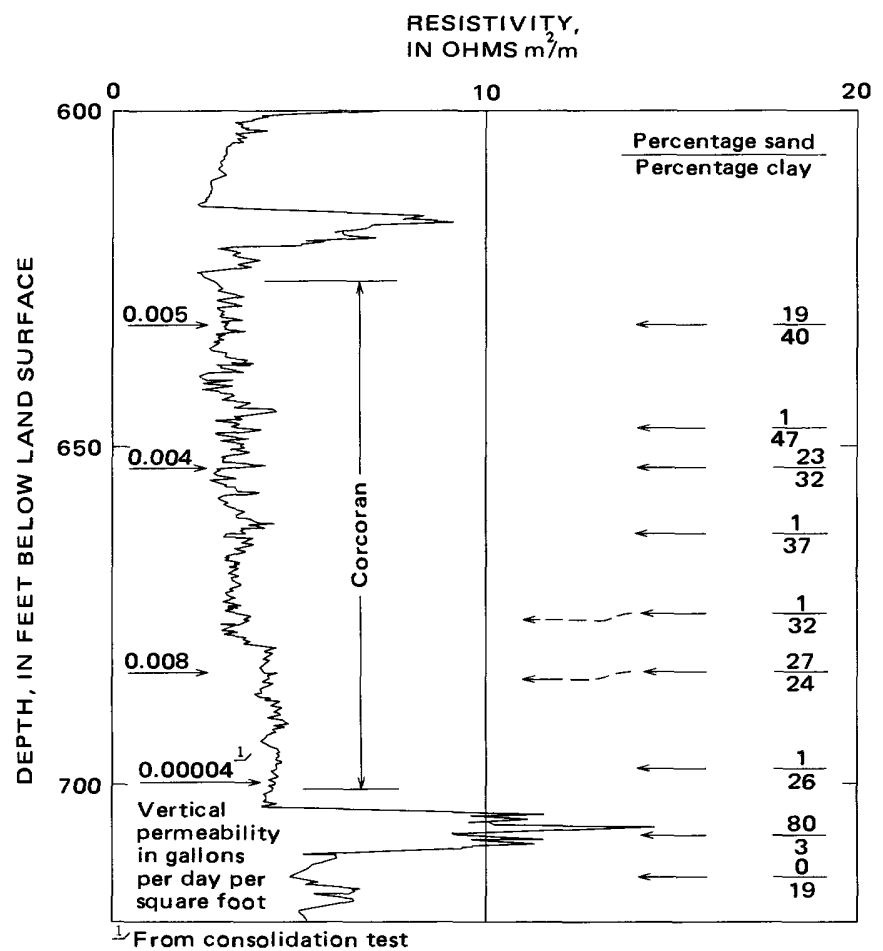

Figune 52,-Bedding, lithology, and vertical permeability of the Corcoran Clay Member of the Tulare Formation and adjacent deposits at the Mendota site, depth 600-721 feet. alternating beds of silty clay and sand-silt-clay, which commonly are less than 1 foot thick.

The lithology of the Corcoran and adjacent deposits, as indicated by the particle-size analyses, is as follows. In the upper part, the beds of silty clay contain more than 40 percent clay, and the beds of clayey silt contain 30-40 percent clay. The clayey silt in the lower onefourth of the Corcoran contains about 25 percent clay. Sand was present in all the samples, but many beds have only 1 percent sand. The maximum sand content was 27 percent. The bed considered to be a lacustrine sand beneath the Corcoran is a clean well-sorted sand, containing 80 percent sand and only 3 percent clay.

The permeabilities of the beds within the Corcoran are consistently low, having a permeability of about $5 \times 10^{-3}$ gal day $^{-1} \mathrm{ft}^{-2}$ (mean of three permeameter tests) or about $4 \times 10^{-5}$ gal day ${ }^{-1} \mathrm{ft}^{-2}$ (mean of three consolidation tests, load range $400-800 \mathrm{lb} \mathrm{in}^{-2}$ ). Minimum permeabilities from consolidation-test results of the Diablo fan deposits were about the same as the minimum permeability observed for a sample from the Corcoran.

Lateral Extent

Lateral extent, as well as bed thickness, is important in determining drawdown and seasonal fluctuation in the vicinity of irrigation wells. Extensive aquifers-as compared to a lensing aquifer system of variable permeability-will tend to reduce drawdown at the wells and increase the seasonal head declines at the midpoints between the wells.

The general lateral extent of four of the types of deposits can be evaluated by study of their modern counterparts. Deltaic sediments are not being deposited in the San Joaquin Valley at the present time.

The deposits with the most extensive bedding are the lacustrine clays and sands. One of the diagnostic features of lacustrine clays such as the Corcoran is their unbroken continuity over thousands of square miles. The thin beds within the lacustrine clays commonly extend for distances of more than several hundred yards. The lacustrine sands are a littoral facies formed by the winnowing action of waves. The sands extend over great distances because they are deposited chiefly during expansions and contractions of a lake.

The flood-plain deposits consist mainly of point-bar deposits, overbank deposits, and quiet water deposits. A lensing nature is typical of these deposits, but considerable lateral continuity of permeability is provided by adjacent point-bar deposits of similar permeabilities. The extent and thicknesses of the lenses probably are greater for the Sierra than for the Diablo flood-plain deposits because the perennial streams from the Sierra Nevada were larger than the perennial streams from the Diablo Range. 
The modern Diablo alluvial-fan deposits lense more than the other types of deposits. Although individual beds may extend for more than 1,000 feet along the radial lines of deposition of a fan, the lateral extent along the fan contours generally is less than 500 feet.

\section{COMPARISON OF BED-THICKNESS FACTORS}

The Terzaghi theory of consolidation (see section "Bedding") states that the time, $t$, needed to establish a specified degree of compaction (pore-pressure decay) in an aquitard that is being drained through both the upper and lower surfaces is a function of the halfthickness of the bed, $h$,

$$
t=c(h / 2)^{2}
$$

The coefficient, $c$, is used for $T / c_{v}$ because variations in the time factor and the coefficient of consolidation are not considered in the following bed-thickness evaluation. This section evaluates the effect of bed thickness on the relative time needed for a specified percentage of compaction to occur in lower-zone aquitards at the four Inter-Agency Committee core-hole sites. The results of the study are summarized in tables 7 and 8 .

Micrologs (microinverse 1 inch $\times 1$ inch logs) of the core holes were used to estimate quantitatively the effects of differences in bed thicknesses for the suites of deposits at each core-hole site. The bed-thickness study also provided a way of assessing the relative times needed for attainment of equilibrium pore pressures for the different types of deposits.

The procedure was as follows. The effect of temperature increase with depth on resistivity was accounted for by drawing a drift line on the electric log, touching the left edges of the beds of minimum resistivity. Aquitard bed thicknesses were measured along a line that was parallel to the resistivity drift line and was offset sufficiently to be to the right of low resistivity beds in the Corcoran.

Beds that extended to the left of the measuring line were classed as aquitards, and those parts of the mi-

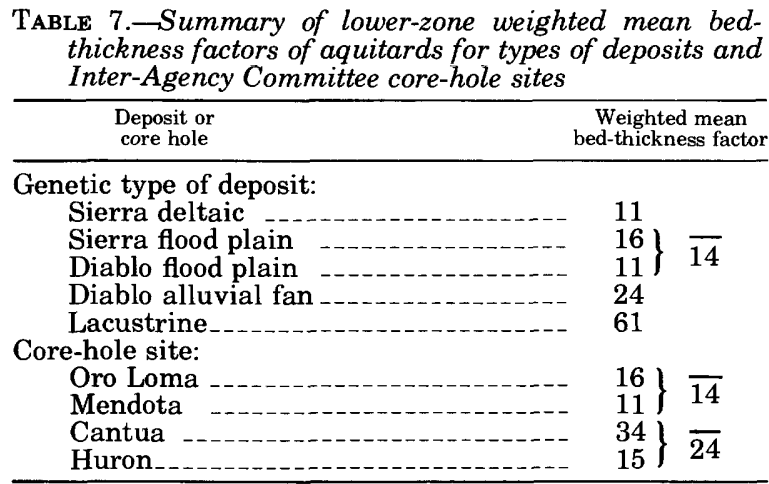

crolog to the right of the measuring line were classed as being chiefly aquifer material. It is unlikely that the "aquitard" beds have sufficient permeability to be considered aquifers. One way to illustrate the conservative approach used would be to check the amounts of silt and clay in the material classed as aquifer material. For example, in the depth range 1,265-1,342 feet in the Mendota core hole, both micrologs were to the right of the aquitard measuring line, and thus no aquitard beds were counted in this depth interval. The coring process recovered samples with the following amounts of fine-grained material (Johnson and others, 1968, p. A48):

\begin{tabular}{|c|c|c|}
\hline & $\begin{array}{l}\text { Percentage silt } \\
\text { and clay }\end{array}$ & $\begin{array}{l}\text { Percentage clay } \\
<0.004 \mathrm{~mm}\end{array}$ \\
\hline 1,269 . & 46 & 24 \\
\hline $1,271$. & -_ 29 & 16 \\
\hline 1,284 . & 14 & 8 \\
\hline 1,293 & 46 & 21 \\
\hline 1,300 & 38 & 21 \\
\hline 1,312 . & 75 & 25 \\
\hline 1,319 . & 37 & 17 \\
\hline 1,330 & 35 & 19 \\
\hline 1,339 & 83 & 21 \\
\hline
\end{tabular}

The mean silt and clay content of the samples was 45 percent, and the mean clay content was 19 percent. It is apparent that some beds to the right of the aquitard measuring line have permeabilities characteristic of aquitards.

The lateral extent of the "aquifers" adjacent to the aquitards also may be important in controlling expulsion of water from aquitards. If lensing reduces the permeability of the aquifers, but not to the extent of being equal or less than the vertical permeability of the aquitards, lateral changes in aquifer permeability are of little importance because water can be transmitted by the aquifers more rapidly than it can be expelled from the aquitards. If, however, clayey sand lenses are completely enclosed by aquitards, bed thicknesses (as measured on the microlog) are less than the effective thicknesses of the aquitards.

The degree of lensing, in decreasing order of importance, for the various types of deposits is alluvial fan, flood plain, deltaic, and lacustrine.

It was considered unlikely that beds a few inches to 1 foot thick could maintain lateral hydraulic continuity to the nearest well (mean distance about one-half mile), particularly in the alluvial-fan deposits. Thus, intermediate- and high-resistivity beds less than 1 foot thick were included in the aquitard thicknesses.

The aquitard thicknesses were classed in 3-footthickness intervals, the percentage of aquitard beds in each thickness range was determined, and weighted mean bed-thickness factors were computed as bed- 
LOS BANOS-KETTLEMAN CITY AREA, CALIFORNIA, PART 2

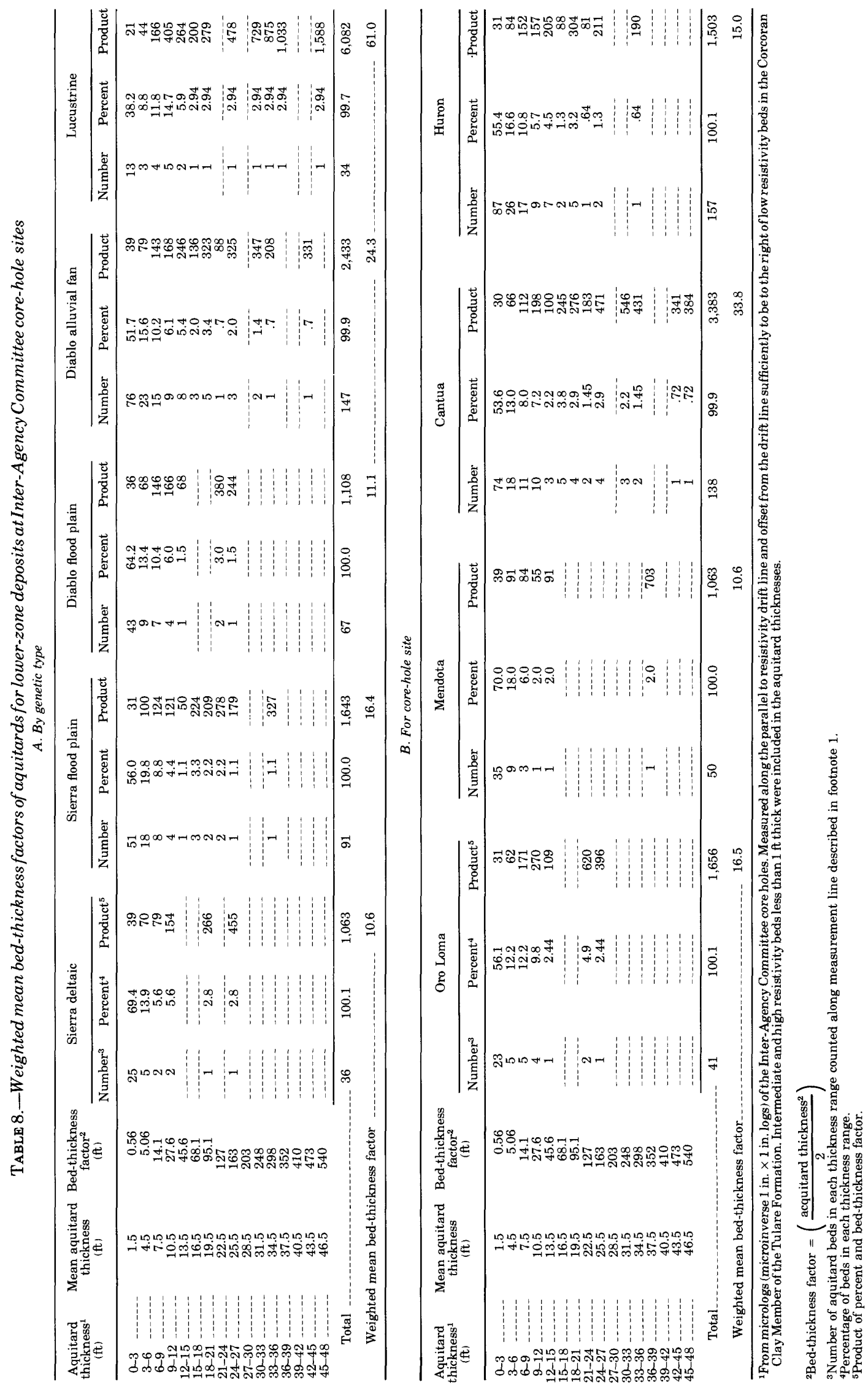


thickness factor $=(\text { aquitard thickness } / 2)^{2}$. Weighted mean bed-thickness factors for the lower-zone deposits, based on the data from the four core holes, are summarized in table 8 .

The mean bed-thickness factors for the genetic types of deposits range from 11 for Sierra deltaic deposits to 61 for lacustrine deposits. Although low, the value of 11 for the deltaic deposits probably is higher than that for the coarser grained Sierra deltaic deposits to the east and southeast of the Huron core-hole site (the only site where this type of deposit was penetrated).

The flood-plain deposits have a mean bed-thickness factor of 14, with thicker aquitards being present in the Sierra than in the Diablo flood-plain sequences. The thicker aquitards in the Sierra flood-plain deposits may be a function of larger rivers entering the area from the Sierra Nevada than from the Coast Ranges. Finegrained deposits, such as would accumulate in oxbow lakes and in backswamp areas, should have been proportionately thicker along the rivers from the Sierra Nevada than along the smaller streams from the Coast Ranges.

Diablo alluvial-fan deposits tend to have distinctly thicker aquitards than either the flood-plain or deltaic deposits. The bed-thickness factor of 24 results in part from the relatively large proportion of intermediateresistivity beds less than 1 foot thick in the fan deposits.

The thickest aquitards occur in the sequences of lacustrine sands and clays, as shown by the large mean bed-thickness factor of 61 . The 86- and 75-foot Corcoran aquicludes at the Oro Loma and Mendota sites were not included, but the 3-14-foot-thick clayey beds within the Corcoran at the Cantua and Huron sites were included in the analysis of lacustrine bed thickness.

Other factors being equal, the mean bed-thickness factors for the different types of deposits indicate the potential for residual excess pore pressures within the lower zone. Flood-plain or deltaic sequences should compact rapidly, but lacustrine sequences can be expected to have maximum residual excess pore pressures. Alluvial-fan sequences are intermediate in the amount of time needed for pore-pressure equilibrium to be attained.

The mean bed-thickness factors at the core-hole sites reflect the types of lower-zone deposits. The deposits at the four core-hole sites consist of two to four genetic types of deposits. The lowest bed-thickness factor is for the Mendota site, where 80 percent of the aquitard beds are in flood-plain deposits.

The Oro Loma and Huron sites have similar inean bed-thickness factors, but greatly different types of deposits. At Oro Loma, flood-plain deposits predominate, but lacustrine beds are present also. At the Huron site, Sierra deltaic deposits in the deepest 400 feet of the core hole reduce the effect of 1,000 feet of alluvial-fan deposits on the mean bed-thickness factor.

At the Cantua site, flood-plain, alluvial-fan, and lacustrine deposits are abundant in the lower zone. All three types of deposits have many thick aquitards, resulting in a high mean bed-thickness factor. On the basis of mean bed-thickness factors, the Cantua site has greater potential for residual excess pore pressures than the other three sites.

With only four sites evaluated in a 2,000-square-mile subsidence area, firm conclusions cannot be drawn regarding the effect of areal bed-thickness variations on residual compaction in the northern and southern parts of the study area. However, the mean bed-thickness factors of 14 for the northern and 24 for the southern parts of the area agree with other evidence that suggests greater amounts of residual excess pore pressure in the southern part of the area.

\section{COMPACTION CHARACTERISTICS}

Laboratory tests made on 18 samples from the Corcoran and the various types of lower-zone deposits provide some general information regarding the consolidation characteristics of the fine-grained beds in different genetic types of deposits. Table 9 gives the mean parameters of the compressibility (compression index) and the rate of consolidation (coefficient of consolidation) for the 18 consolidation tests. Most of the conclusions derived from the results of the tests should be regarded as tentative because of the small number of tests involved. The results indicate the following decreasing order of compressibility for the fine-grained beds: lacustrine, Diablo flood plain, Diablo alluvial fan, and Sierra flood plain. The rate of consolidation for the suites of samples decreases in the following order: Diablo flood plain, Sierra flood plain, lacustrine, and Diablo alluvial fan.

The consolidation tests suggest the following generalizations. The lacustrine deposits should undergo large amounts of compaction, but over long periods of time. The Sierra flood-plain deposits should undergo only moderate amounts of compaction, and the compaction should occur fairly rapidly. The Diablo

TABLE 9.-Mean consolidation characteristics of the Corcoran and the different types of lower-zone deposits in the load range 400-800 lb in ${ }^{-2}$ [Samples from fine-grained beds at the four Inter-Agency Committee core-hole sites]

\begin{tabular}{|c|c|c|c|}
\hline Source ${ }^{1}$ & $\begin{array}{c}\text { Number } \\
\text { of } \\
\text { tests }\end{array}$ & $\begin{array}{c}\text { Mean } \\
\text { compression } \\
\text { index }{ }^{2} \\
\left(C_{c}\right)\end{array}$ & $\begin{array}{c}\text { Mean } \\
\text { coefficient } \\
\text { of consolidation } \\
\left(c_{v}, \text { in } \mathrm{ft}^{2} / \mathrm{yr}\right)\end{array}$ \\
\hline Diablo: & & & \\
\hline $\begin{array}{l}\text { Alluvial fan } \\
\text { Flood plain }\end{array}$ & $\begin{array}{l}6 \\
6\end{array}$ & $\begin{array}{r}0.37 \\
46\end{array}$ & $\begin{array}{r}8.1 \\
328.5\end{array}$ \\
\hline Sierra: & & & \\
\hline Flood plain & 2 & .33 & 20.8 \\
\hline $\begin{array}{l}\text { Combined Diablo and Sierra: } \\
\text { Lacustrine deposits }\end{array}$ & 4 & .82 & 17.5 \\
\hline
\end{tabular}

${ }^{1}$ From Miller, Green, and Davis (1971)

2From Johnson, Moston, and Morris (1968, table 9).

${ }^{3}$ Median instead of mean used because of one excessively large value. 
alluvial-fan deposits should undergo moderately large amounts of compaction, but long periods of time will be required for ultimate compaction to be achieved. The Diablo flood-plain deposits should undergo moderately large amounts of compaction, and the compaction should occur more rapidly than for either the alluvialfan or lacustrine deposits.

Evaluation of the bedding, lithology, permeability, and lateral extent of the five types of deposits discussed in figures 48-52 results in conclusions similar to those derived from the consolidation tests regarding the different amounts and rates of compaction in response to increase in applied stress. The following interpretations should be considered as generalizations.

The Sierra flood-plain deposits should compact the most rapidly because of their high permeability, but the total amount of compaction should be smaller than for the other types of deposits because sections of sand thicker than 50 feet that contain less than 10 percent clay are common. The presence of mica in the Sierra sands results in higher elastic and inelastic components of compaction than in sands containing no mica.

The Diablo alluvial-fan deposits contribute substantially to the large amounts of compaction that have occurred in the southern part of the area because of the fine-grained compressible nature of most of the fan deposits. The many coarser grained beds of varying thickness furnish a means of escape for the water being expelled from the slowly draining intercalated clay beds. However, the rate of compaction for a given increase in applied stress probably is less than for either the Sierra or Diablo flood-plain deposits. The combined effects of large amounts of clay, even in the aquifers, and the highly lensing character of the overall suite of fan deposits tends to retard the expulsion of water from the aquitards and create a condition favorable for large amounts of residual excess pore pressure.

The Diablo flood-plain deposits have characteristics that are almost ideal for large amounts of compaction to occur rapidly. Large amounts of compressible clayey material are present, and most of the beds of clayey material are only 4-8 feet thick. Almost 90 percent of these aquitards at the core-hole sites were less than 9 feet thick (table $8 A$ ). Although they contain large amounts of silt and clay, the highly compressible fine-grained beds within the Diablo flood-plain deposits have higher permeabilities than the fine-grained beds of the alluvial-fan deposits. Sand beds with good to moderate permeability, and having large lateral extents, commonly occur between the clay beds, thus providing ready avenues of drainage for the water expelled from the clayey beds.

The fine-grained facies of the Sierra deltaic deposits might be expected to compact to a moderate extent over a long period of time. The ultimate specific unit compaction of the Sierra deltaic deposits probably is less than that of beds with similar petrologic characteristics in the upper zone because of the large stresses that have been applied to the deeply buried deltaic deposits in the geologic past.

The compaction characteristics of the Corcoran should be opposite to those of the Sierra sands. The Corcoran is highly compressible, but the rate of compaction is very slow because of the great thickness and low permeability of this lacustrine unit (Miller, 1961). The low permeabilities of even the clayey silt beds more than offset the tendency of good lateral extent of the beds to cause a more rapid rate of compaction. Pore pressures in the middle of the thickest lacustrine clay beds may not have declined much, despite the large declines in pore pressures in the aquifers above and below the Corcoran. Analysis of the compaction and water-level record at the Lemoore site suggests that compaction may continue at a very slow rate in lacustrine clays after artesian-head recovery in the aquifers of 50 feet from the previous summer low.

\section{REGIONAL RELATIONS}

Areal variations in the age, prior total applied stress, mean lithology, and source and mode of deposition of the deposits are responsible for much of the areal variations in the amounts of compaction upon increase in applied stress caused by pumping of ground water in the Los Banos-Kettleman City area. Both the degree of variation of these geologic factors and their effect on mancaused compaction and subsidence will be the subject of this section.

\section{AGE OF THE DEPOSITS}

The older deposits in the study area have had more time in which to undergo diagenetic changes, which have increased their ability to withstand further increase in applied stress. Diagenetic changes not only include sufficient time for the compaction of thick clay beds, but also cementation of the sandy deposits resulting from precipitation of part of the dissolved solids from water passing through the deposits or from solution of part of the grains at the points of contact and redeposition in the areas of lesser grain-to-grain pressure. Mineralogic changes occur also with changing pressure, temperature, and chemistry of the contained waters.

Most of the Pleistocene deposits are considered to be unconsolidated, even though in part they are buried to depths of more than 1,000 feet. The Pliocene marine and continental deposits show more effects of time when compared with Pleistocene deposits of similar lithology. The clayey deposits, instead of being plastic when handled, are sufficiently brittle that samples will break 
when struck with a hammer. The sandy deposits, instead of being loose, are sufficiently cemented that they are cohesive, but friable to the touch. Lenses or concretionary nodules of calcareous sandstone are common. The degree of lithification of the Pliocene waterbearing deposits is not advanced, however, and weathered outcrops of Pliocene materials commonly appear to consist largely of unconsolidated materials.

The following stratigraphic and descriptive information about the deposits tapped by water wells in the study area is summarized from Miller, Green, and Davis (1971):

\begin{tabular}{|c|c|c|c|}
\hline Formation & Age & Lithology & Depositional environment \\
\hline Tulare & $\begin{array}{l}\text { _Pliocene and } \\
\text { Pleistocene. }\end{array}$ & $\begin{array}{l}\text { Sand, silt, } \\
\text { and clay. }\end{array}$ & $\begin{array}{l}\text { Continental-alluvial fan, } \\
\text { flood plain, lacustrine, } \\
\text { deltaic. }\end{array}$ \\
\hline San Joaquin & Pliocene & $\begin{array}{l}\text { Clay, silt, } \\
\text { sandstone. }\end{array}$ & Marine and continental. \\
\hline Etchegoin ${ }^{1}$ & _Pliocene & $\begin{array}{l}\text {-Sand and silt. } \\
\text { blue to } \\
\text { brown. }\end{array}$ & $\begin{array}{l}\text { Marine, fluviatile, } \\
\text { lacustrine. }\end{array}$ \\
\hline Kreyenhagen & $\begin{array}{l}\text { Eocene and } \\
\text { Oligocene. }\end{array}$ & $\begin{array}{l}\text { Organic, } \\
\text { siliceous } \\
\text { shale. }\end{array}$ & Marine. \\
\hline
\end{tabular}

${ }^{1}$ Upper part tapped by water wells south and west of Cantua Creek (town).

A map showing those parts of the area where wells tap the pre-Tulare marine and continental Pliocene deposits is shown in Part 1 (Bull and Miller, 1974, fig. 15). Two such areas are present adjacent to the foothills of the Diablo Range-one opposite the Panoche Hills and the other opposite the Big Blue Hills and Anticline Ridge. In the northern area the wells are shallow, some of them reaching the Kreyenhagen Formation at depths of only 1,200 feet, and the bulk of the water pumped by the wells is derived from flood-plain deposits within the Tulare Formation. In the southern area, wells as deep as 3,500 feet tap the marine sands of the Etchegoin and San Joaquin Formations. Most of the ground water pumped within 5 miles of the Big Blue Hills probably is derived from these Pliocene deposits.

Amounts of subsidence have been minor where wells derive most of their water from the Etchegoin Formation or other pre-Tulare Pliocene deposits. The artesian head has declined as much as 500 feet in the area adjacent to the Big Blue Hills, but only about 1 foot of subsidence has occurred. The low specific compaction of these deposits indicates that the Pliocene deposits are much less compressible than the deposits of the overlying Tulare Formation. Part of the reason for the sharp decrease in subsidence on the west end of profile $B-B^{\prime}$ of figure 17 may be attributed to the fact that the wells derive their water in part from pre-Tulare formations.

\section{SPECIFIC UNIT COMPACTION OF THE LOWER-ZONE DEPOSITS}

In evaluating the long-term relations between change in applied stress and compaction, Bull (Pt. 3, Bull and Poland, 1974) derived a specific compaction map of the lower zone for 1943-60. In making the map, the following factors were evaluated: (1) the one component of stress change caused by lower-zone artesianhead decline, (2) the three components of stress change caused by change in the position of the water table, and (3) total subsidence for the period and the proportion of subsidence that was due to lower-zone compaction. Compaction of the lower zone in the 1943-60 period was estimated, utilizing the observed proportions of compaction occurring in the lower zone in the 1960's (fig. 45; see also section "Proportions of Compaction Occurring in the Upper and Lower Zones," paragraph 3).

The specific unit compaction of the lower-zone deposits can be computed by dividing the specific compaction by the thickness of deposits undergoing porepressure decline. The perforated interval of the lower zone is used for this purpose. The maximum thickness of the lower-zone perforated interval is based on the well tabulation compiled by Ireland (1963), which lists the perforated-interval data for wells drilled before 1962 . Since 1960, fewer wells have been tapping the brackish waters that occur at the base of the lower zone, but the tabulation is an excellent source of information regarding the distribution of perforated intervals of pumping wells during the 1943-60 period.

The maximum thickness of the perforated interval of the lower zone is shown in figure $53^{2}$. The thickness of lower-zone deposits being tapped ranges from less than 400 feet to more than 2,400 feet. The general pattern is one of overall increasing thickness of perforated interval toward the southwest. Thicknesses of more than 1,800 feet occur in the areas of pumpage from the Etchegoin Formation. In the vicinity of Fresno Slough and Kings River, the thickness of fresh-water-bearing deposits extends below the base of the perforated interval (Miller and others, 1971, pl. 4), but wells can obtain a sufficient yield without penetrating the full thickness of fresh-water-bearing deposits. Pore-pressure decline may be occurring below the base of the perforated interval in the vicinity of Fresno Slough and Kings River as a result of the large amounts of water being pumped from the deeper aquifers farther to the west. An example of this type of head decline is shown at the Yearout site by Bull (Pt. 1, Bull and Miller, 1974, fig. 24).

The specific unit compaction map for the lower zone, $1943-60$, is figure 54. The values would represent the variation in compressibility of the lower-zone deposits if pore-pressure equilibrium had existed throughout the aquifer systems in 1943 and 1960. The specific unit compaction ranges from about 0.5 to more than $10.0 \times 10^{-5} \mathrm{ft}^{-1}$ (foot per foot of aquifer-system thickness per foot of increase in applied stress). Because of the complexity of the many factors used in computing regional specific unit compaction, the purpose of the

\footnotetext{
2Same as figure 18, Part 1; construction of map described in Part 1 (Bull and Miller, 1974).
} 


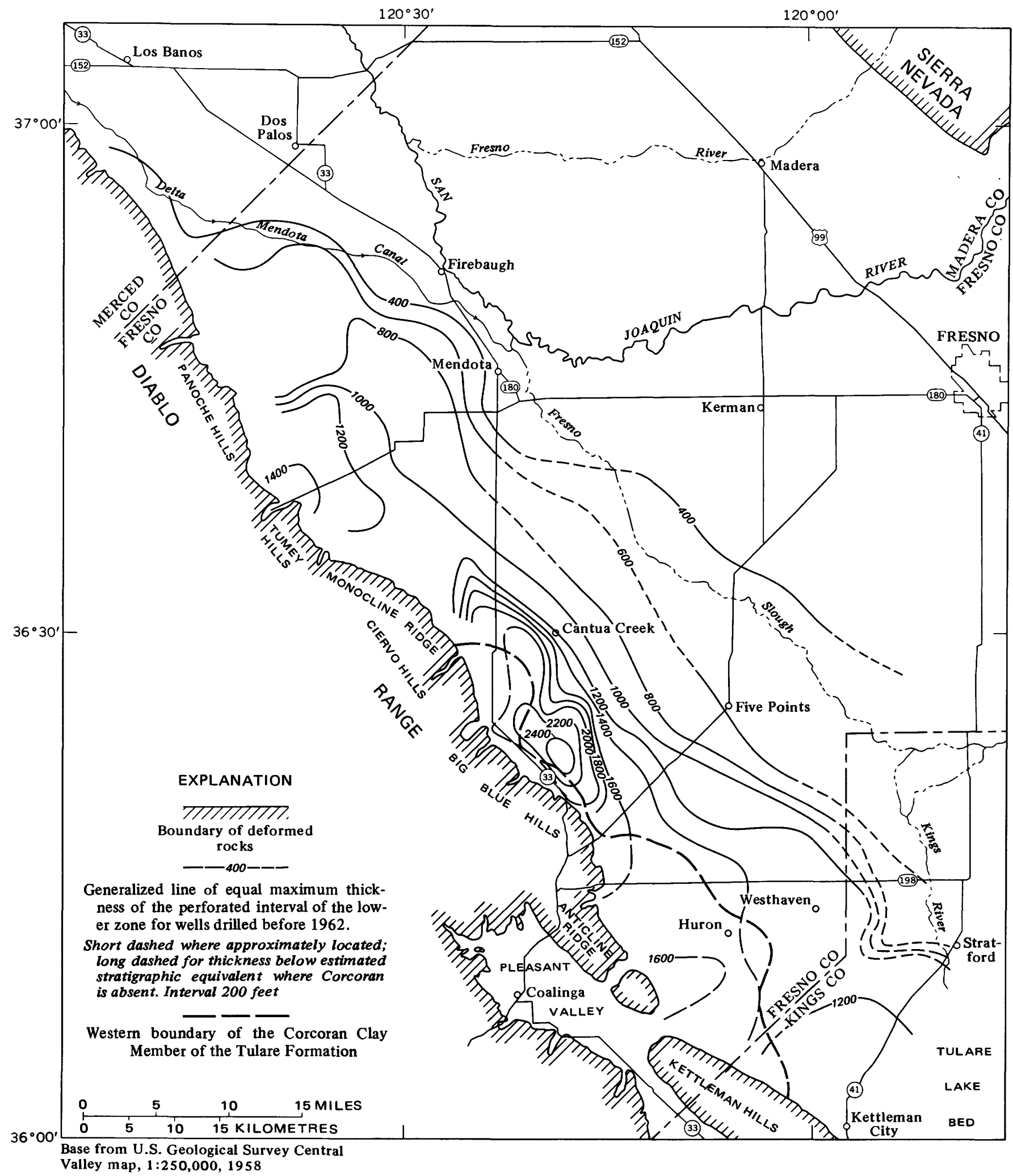

FiguRE 53.-Maximum thickness of the perforated interval of the lower zone.

map should be to illustrate general variations rather $\mid$ values of specific unit compaction generally are bethan to show precise values of specific unit compaction. tween 1 and $3 \times 10^{-5} \mathrm{ft}^{-1}$, but in the northern part of the In the southern and central parts of the study area, $\mid$ area values of specific unit compaction generally exceed 


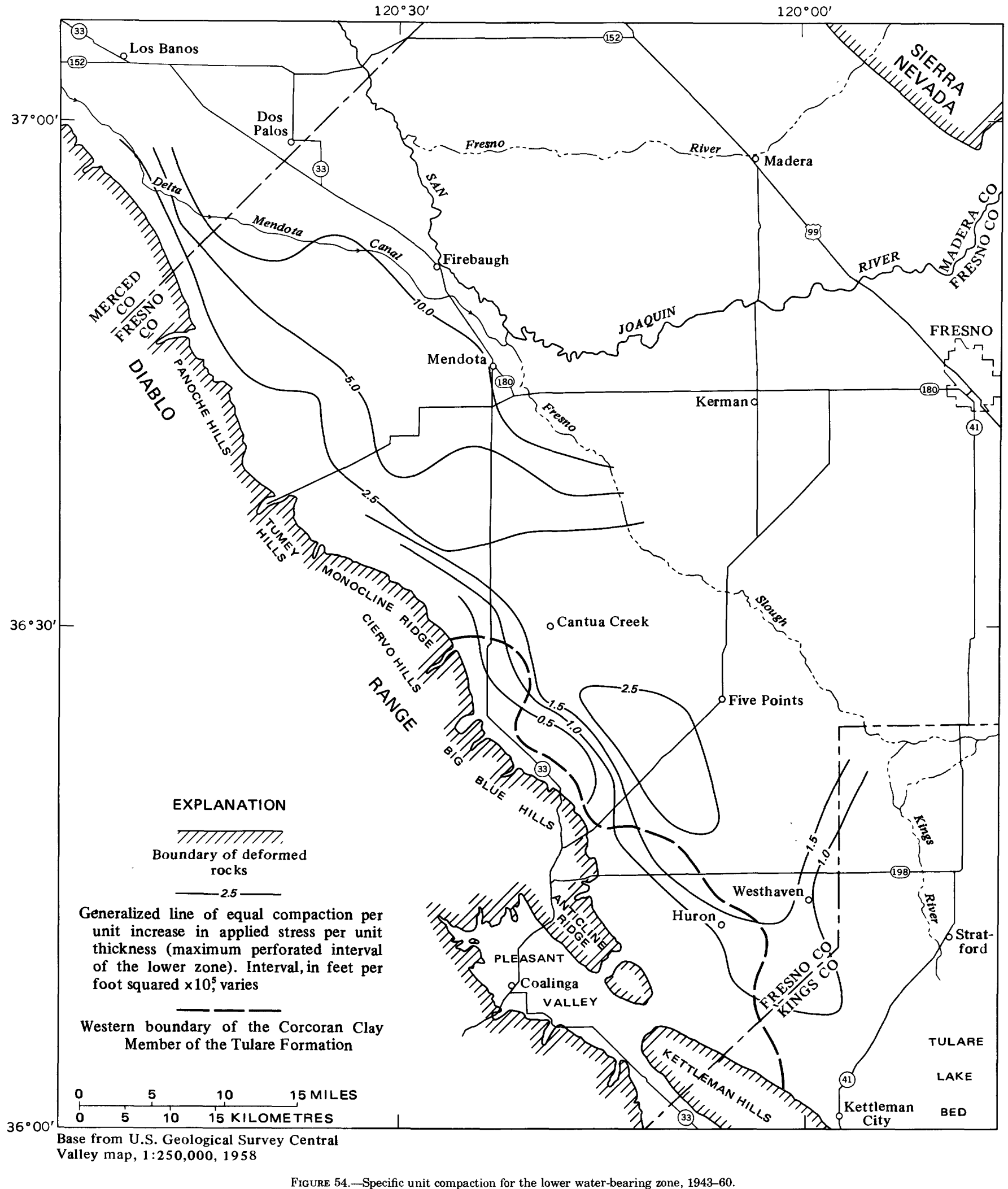

$3 \times 10^{-5} \mathrm{ft}^{-1}$; northeast of the Delta-Mendota Canal, Thus, the most important feature of the map is a values of specific unit compaction generally exceed distinct indication that the deposits in the northern part $10 \times 10^{-5} \mathrm{ft}^{-1}$. of the area apparently are four times as compressible as 
the deposits in the central and southern parts of the study area. The maximum value of the line of equal specific unit compaction for the northern part of the study area is four times that for the southern part of the area. Means of specific unit compaction from a 91-point grid also show a fourfold difference when a subarea north of the north boundary of township 16 south is compared with a subarea south of that boundary.

Most of the rest of this section will be devoted to consideration of various geologic and hydrologic factors in an attempt to determine whether the deposits in the northern part of the area are indeed more compressible or whether other factors such as the rate of compaction of different genetic types of deposits are important in causing the contrast in specific unit compaction in the northern and southern parts of the study area.

Geologic Factors Influencing Specific Unit Compaction

PRIOR TOTAL APPLIED STRESS

One of the geologic factors that might cause the lateral variation in specific unit compaction is the variation in stress that was applied on the lower-zone deposits in the northern and southern parts of the area before the 1943-60 period. In the northern part of the area, the depth to the base of the lower zone ranges from about 1,000 feet to about 2,000 feet, whereas in the central and southern parts of the area, the depth to the base of the lower zone ranges from about 1,300 to about 3,000 feet.

The difference in depths to the base of the lower zone suggests the hypothesis that in the central and southern parts of the area, the greater prior total applied stress has already compacted the deposits to such an extent that they are less compressible per unit increase of additional applied stress than the deposits in the northern part of the area. The effect of prior total applied stress on compressibility of the deposits at the Westhaven site was discussed in the section "Overburden Load," paragraph 3. This hypothesis can be evaluated by determining the total applied stress on the middle of the lower zone and then by taking the product of the total applied stress on the middle of the lower zone and specific unit compaction to largely remove the effect of prior total applied stress.

The depth to the middle of the lower zone is shown in figure 55. The middle of the lower zone was selected as a reference surface on which to define the total applied stress as of 1943-the beginning of the 1943-60 period used for computation of specific unit compaction. Maximum depths to the middle of the lower zone are the same in the northern and southern parts of the area -about 1,500 feet. In the central part of the area, maximum depths exceed 2,000 feet in the area of pumpage from the Etchegoin Formation. The minimum depths to the middle of the lower zone are less in the northern part of the area-600-800 feet-than in the southern part of the area-800-1,000 feet.

The depth would be roughly proportional to the total applied stress on the middle of the lower zone if the entire section were saturated and if no confining beds were present to cause potential head differentials. Because unsaturated deposits and confinement exist in the study area, corrections have to be made to figure 55 to derive the total applied stress on the middle of the lower zone. The gravitational stress of the saturated deposits is roughly equal to 1 foot of water per foot of thickness.

The total applied stress of the deposits above the water table is about 1.8 foot per foot (assuming a moisture content of 0.2 the volume). The additional stress due to the unsaturated condition of the deposits above the water table is shown in figure 56. The lines of equal applied stress were computed by multiplying the thickness of deposits above the water table, as of 1951 , by 0.8 . The lack of saturation of these deposits results in a correction factor that locally increases the stress on the middle of the lower zone by more than 200 feet of water. The component of increased applied stress is minor in the northeastern part of the area, but in much of the area, the stress was 50-200 feet of water greater, as of 1951 , because of the large thicknesses of deposits above the water table.

The difference in applied stress on the lower zone resulting from differences in the position of the water table between 1951 and 1943 is minor. Although a water-table map is not available for 1943 , spot checks indicate that the position of the water table was within 40 feet of the 1951 position. Although 40 feet of watertable change would cause 32 feet of stress change in the water-table aquifer as a result of change of the saturated condition of the deposits, the net effect of watertable change on the total applied stress on the lower zone is minor. The change in seepage stress resulting from water-table change more than offsets the stress change due to change in saturation of the deposits. The net effect is only 0.2 foot of water per foot of change in position of the water table (Pt. 3, Bull and Poland, 1974). Forty feet of water-table change would cause only 8 feet of net change in applied stress on the lower zone. If the maximum error introduced by using the 1951 , instead of the 1943 , water-table data is 10 feet of net stress change on the lower zone, it can be readily concluded that the magnitude of the error is insignificant compared to the 200 -foot interval used for the 1943 total applied stress map (fig. 58).

The other correction component that needs to be applied to figure 55 to get the total applied stress on the middle of the lower zone is the seepage stress caused by 


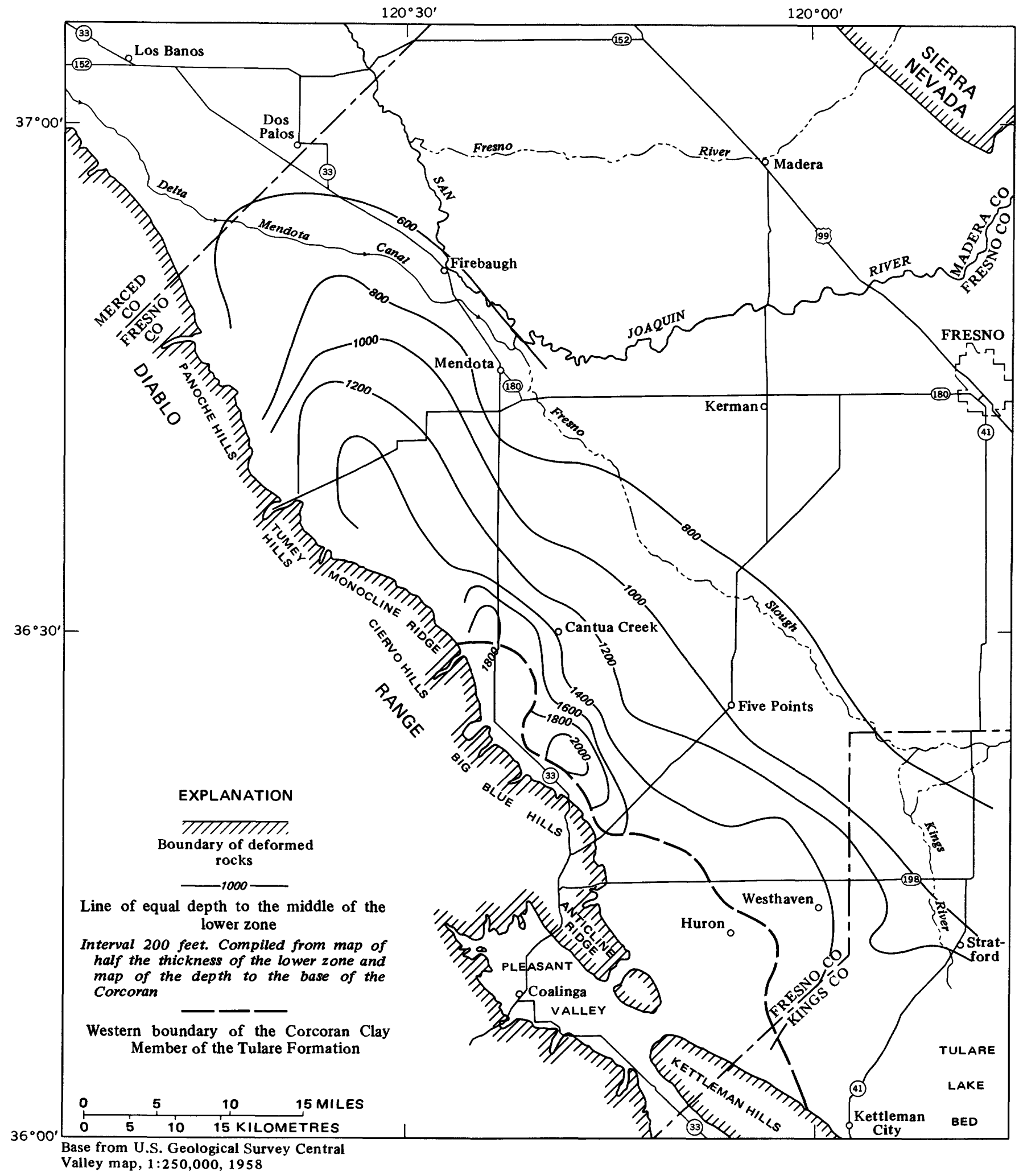

FIGURE 55.-Depth to the middle of the lower zone. 


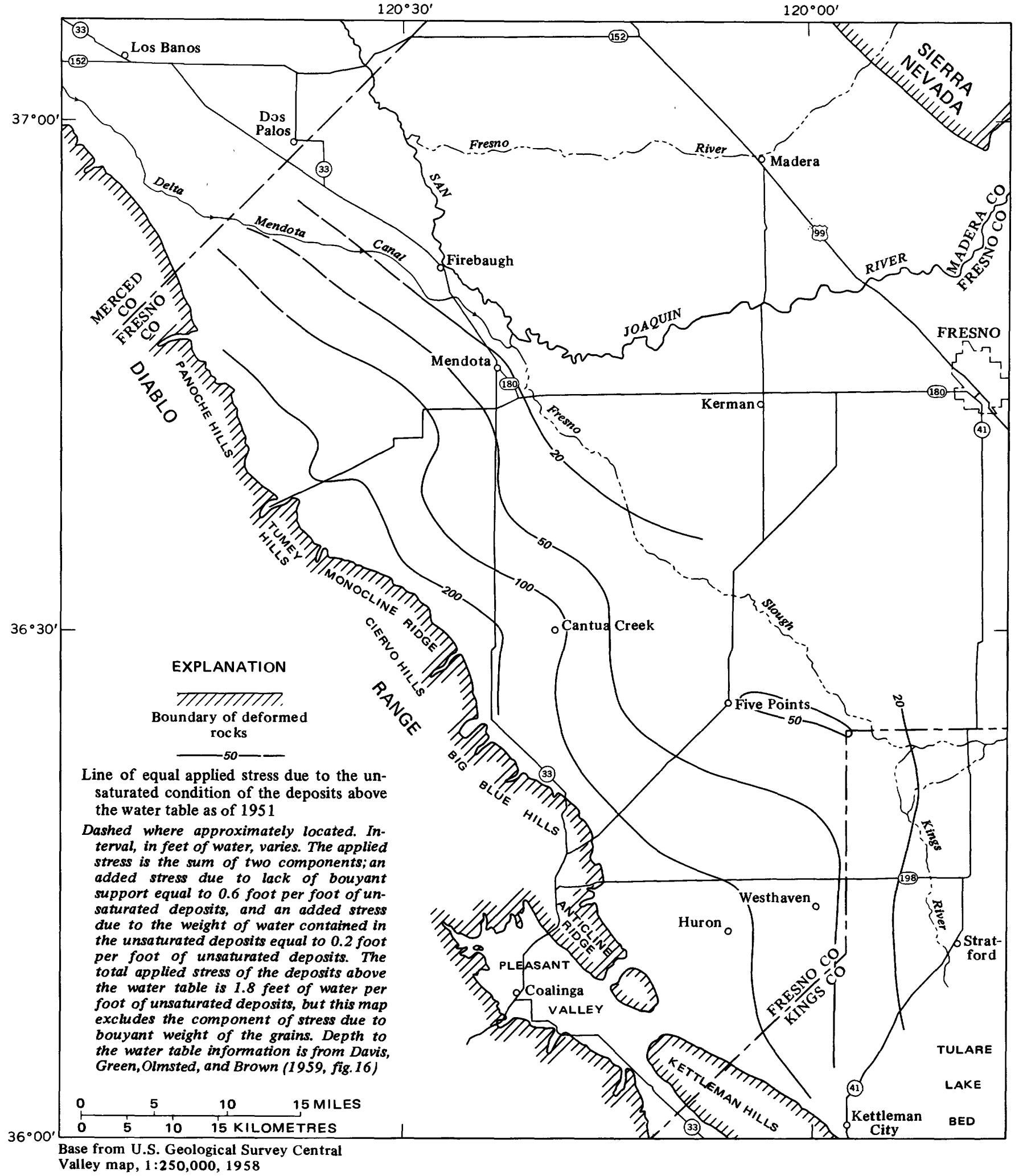

Figure 56.-Applied stress due to the unsaturated condition of the deposits above the water table as of 1951. 
head differentials between the water table and the potentiometric surface of the lower zone. The 1943 position of the lower-zone potentiometric surface was used to define the magnitude of the seepage stresses present in the area at the beginning of the 1943-60 period. The water level in wells tapping the lower zone rises as much as 500 feet above the base of the Corcoran, and before 1925 the artesian head was sufficient to cause wells to flow in the eastern part of the area (Pt. 1, Bull and Miller, 1974, fig. 21). However, by 1943, the potentiometric surface was below the water table throughout the area, and the resulting seepage stress on the lower zone was caused by, and equal to, the head differential between the water table and the potentiometric surface of the lower zone.

The seepage stress on the lower zone, as of 1943 , is shown in figure 57. Seepage stress exceeded 100 feet of water in most of the area and locally was more than 200 feet of water. The areas of maximum seepage stress coincide with the areas of maximum pre-1943 pumping of ground water-about midway between Fresno Slough and the Diablo Range. Not all the increase in stress applied to the lower zone as of 1943 had become effective in the fine-grained beds of low permeability at that date.

Head differentials occur in the area west of the Corcoran also, as shown by comparison of the position of the water table and water levels in wells perforated to depths of more than 2,000 feet. Variations of head differentials occur more abruptly in the area west of the Corcoran than in the rest of the area where the Corcoran is present to provide uniform confinement for the lower zone.

The total applied stress on the middle of the lower zone was obtained by adding the stress components shown in figures 56 and 57 to lines of equal depth to the middle of the lower zone, multiplied by 1.0 foot of water per foot of deposits. The combination of these three maps, figure 58, shows that the total applied stress on the middle of the lower zone, as of 1943 , ranged from 600 to 2,200 feet of water. Throughout most of the area, the total applied stress was $1,000-1,800$ feet. The amounts of total applied stress are about the same in the northern and southern parts of the area, except that the area west of Firebaugh is the area of lowest total applied stress in the study area west of the valley trough. The total applied stress in the central part of the area, where wells tap the Pliocene deposits, is almost one-third greater than the maximum amounts of stress that occur to the north and south. The lines of total applied siress were not extended west of the Corcoran, but the total applied stress in the area to the west of Huron seems to be in a narrow range between 1,600 and 1,800 feet of water.
STRESS-COMPACTION PRODUCTS

The purpose of making the total applied stress map was to assess the influence of variation in prior applied stress on the apparent compressibility of the various types of deposits. The stress was determined as of 1943 . The amounts of estimated compaction and increase in applied stress were obtained for the 1943-60 period. The effect of prior total applied stress on specific unit compaction for the 1943-60 period was removed by multiplying the specific unit compaction by the total applied stress.

The validity of the use of such a product needs to be examined critically. The use of a simple product of total applied stress and specific unit compaction assumes that an arithmetic linear relation exists between compressibility and effective stress. Laboratory consolidation tests show that compressibility decreases with increasing effective stress.

The exponential decrease in compressibility with increasing effective stress for both the laboratory and field ranges of stress for two consolidation tests is shown in figure 59. The compressibility plots are from J. F. Poland (written commun., 1968), and I have added compressibility-effective stress products to the plots to show how the effect of variable effective stress can be almost eliminated. Sample A is the test result for the Cantua site that has the most extreme change of compressibility-effective stress product with increasing effective stress. The sample for case A was taken from a thin bed within the Corcoran lacustrine sequence.

The compressibility-effective stress products for sample A range from 0.133 to 0.280 , showing that for the laboratory (and extrapolated) range of stresses, the use of products does not eliminate the effect of different effective stresses. Although a 110 percent difference is shown by the two extreme compressibility-stress products, a substantial reduction in the effects of different effective stresses has been made because the difference in the compressibilities of the two points is 3,600 percent.

The results of case $B$ are for a sample that is much less compressible than sample A but which has a compressibility that probably is greater than the lower-zone clayey sands from the Cantua site for which consolidation tests were not made. The change of compressibilityeffective stress products is much less than in case A; only a 7-percent change in the products occurs between the end-point values of 0.026 and 0.028 . Thus, for deposits having compressibilities similar to that of sample $\mathrm{B}$, the use of compressibility-effective stress products eliminates most of the effect of different effective stresses, even for the extreme range of load used in the laboratory. 


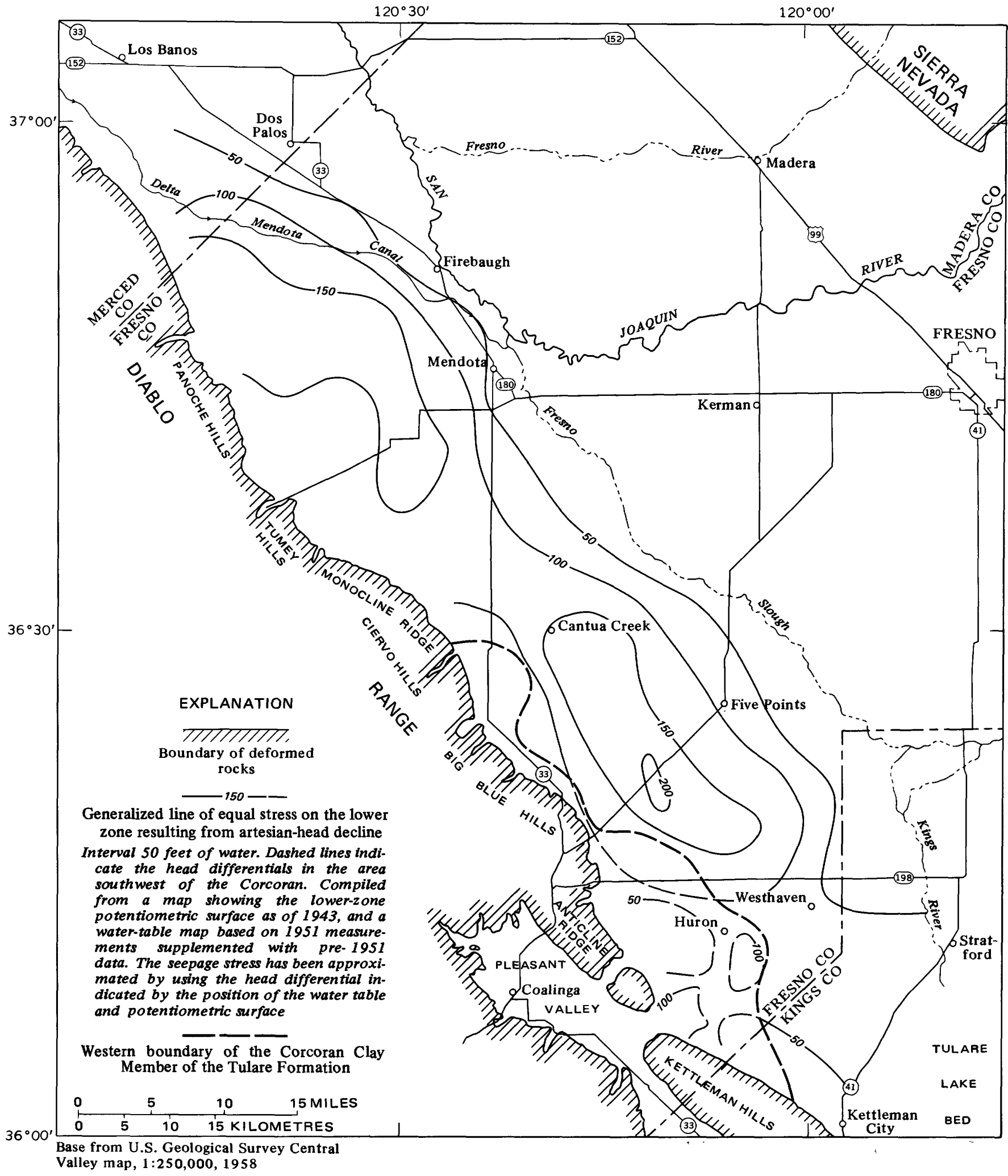

Figure 57.-Seepage stress on the lower zone as of 1943.

The reason that compressibility-effective stress prod- to unity. If the slopes had been substantially different ucts almost eliminate the variations due to effective from unity, exponential corrections (rather than simple stress is that the slopes of the lines in figure 59 are close products) would have been necessary to reduce the ef- 


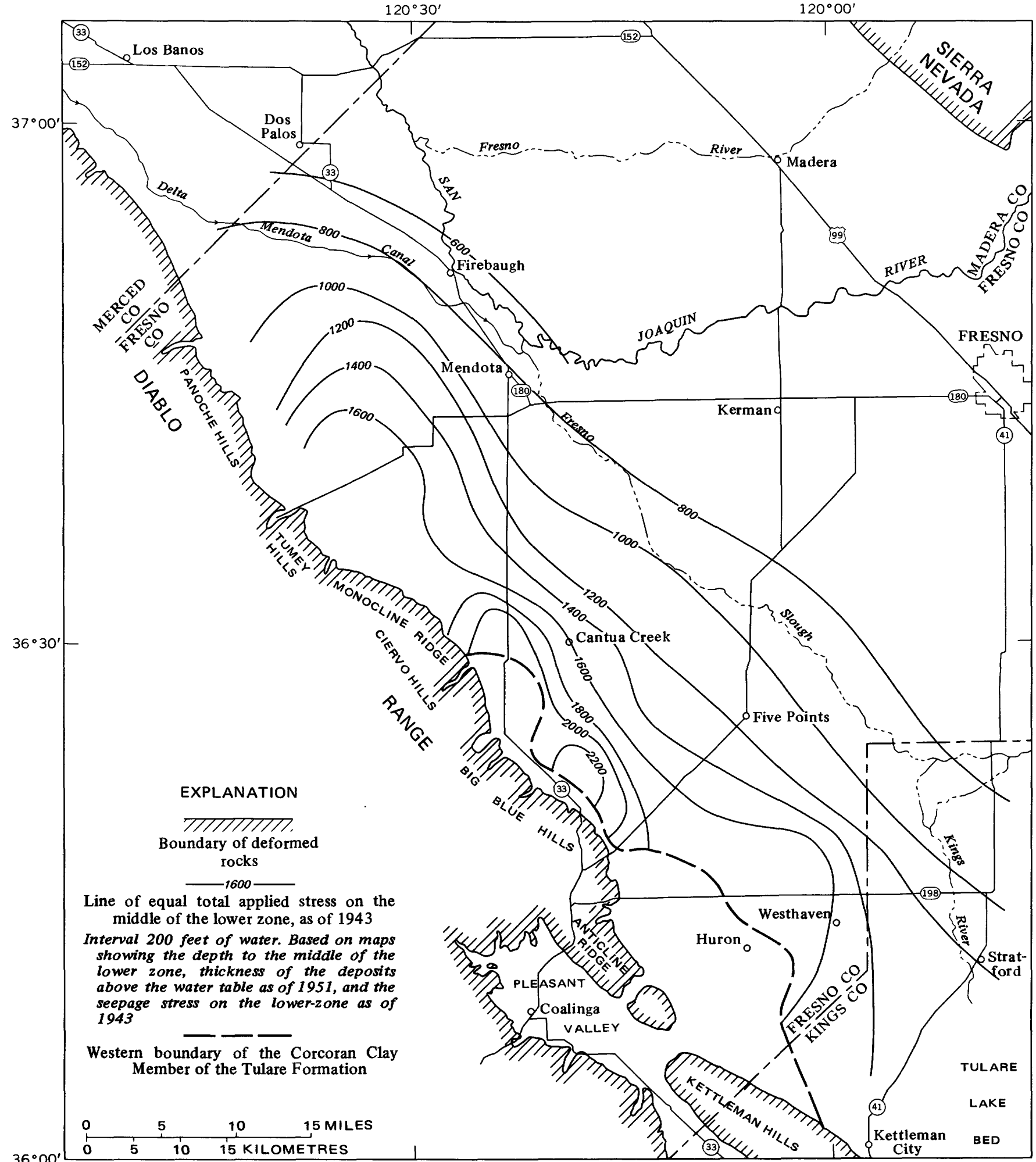

Base from U.S. Geological Survey Central

Valley map, $1: 250,000,1958$ 


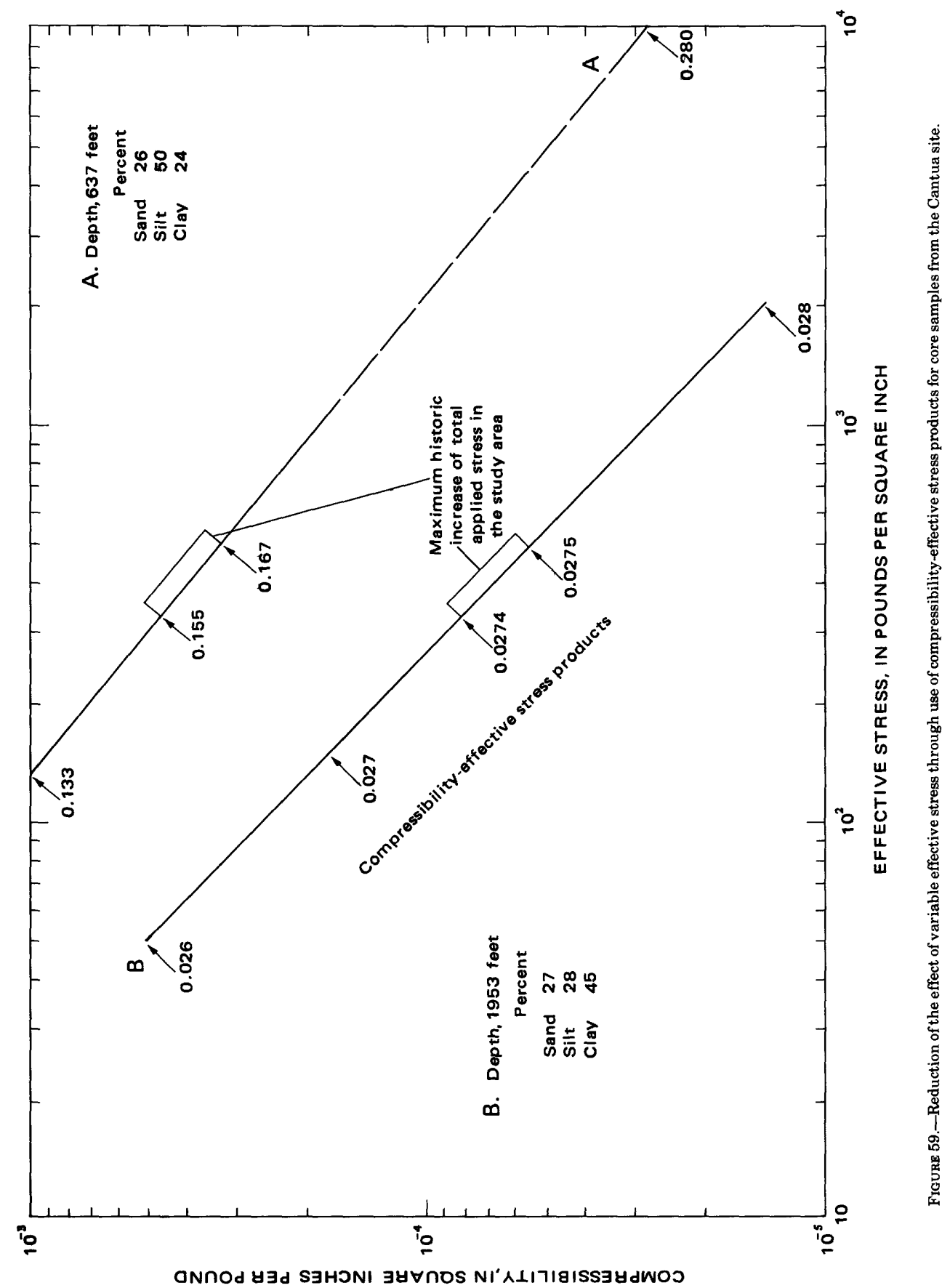


fect of variable effective stress. If we let $m_{v}$ be the compressibility and $P_{e}$ the effective stress, then

$$
m_{v}=c P_{e}^{n} \text {. }
$$

The values of $n$ (the rate of change of $m_{v}$ with respect to $P_{e}$ ) generally are only slightly less than 1.00 . The maximum departure from unity for all the samples tested from the Cantua site is that of sample A.

An appraisal of the changes of stress-compaction factors under field - not laboratory-load ranges is necessary to complete the assessment of the validity of the approach used in this paper. The maximum possible error introduced by assuming a linear compressibilityeffective stress relation can be estimated by using the maximum historic increase of total applied stress that has occurred at the Cantua core-hole site. The increase in applied stress is the result of 400 feet of head decline since about 1900 and, if taken a short distance below the Corcoran, indicates that a 52-percent increase in applied stress has resulted from man's change in the hydrologic environment. At the 600-foot depth at the Cantua site, the applied stress has increased from 330 to about $500 \mathrm{lb} \mathrm{in}^{-2}$. By taking the extremes of compressibility (case $A$ ), and increase in applied stress, it can be seen that a change in the products of $0.155-0.167$ occurs-an indication that only 92 percent of the effect of different stresses has been removed. However, in the case of less compressible materials (case $B$ ), 99.4 percent of the effect of different applied stresses has been removed. Thus, it is concluded that the use of stresscompaction products in this paper does not entirely eliminate the effects of variation in total applied stress within the study area but that more than 90 percent of the effects of variation of total applied stress are removed.

The stress-compaction products will be used in this paper to evaluate the effects of prior total applied stress, mean lithology, and source and mode of deposition on variations of specific unit compaction between the northern and southern parts of the area. The products are apparent compressibilities, for which the effect of prior total applied stress has been largely removed. The products are only apparent compressibilities because the degree to which applied stresses have become effective is not known precisely.

The product of lower-zone specific unit compaction and the total applied stress on the middle of the lower zone is shown in figure 60. As in the case of the specific unit compaction map (fig. 54), the maximum values of stress-compaction products occur in the northern part of the area. The maximum value of the line of equal stress-compaction products for the northern subarea is twice that for the southern subarea (south of township 15 in fig. 1). Means of stress-compaction products from a 91-point grid indicate a $2^{1 / 2}$-fold difference between the northern and southern subareas. Thus, the difference in apparent compressibility between the subareas appears to have been decreased by removing the effect of prior total applied stress.

The amount of change, however, varies greatly in both subareas. Locally, the apparent compressibility has been decreased 50 percent in the northern subarea and increased 100 percent in the southern subarea, when changes in the apparent compressibility indices at selected points are compared with the mean indices of the other subarea. At other locations, little or no change in apparent compressibility resulted from the use of stress-compaction products instead of specific unit compaction. Thus, the effect of prior total applied stress is important at some locations, whereas at others the effect of prior stress on apparent compressibility is completely obscured by petrologic factors. A similar conclusion was reached by Meade (1968) regarding the factors affecting change of void ratio with depth at the Richgrove core-hole site in the southern San Joaquin Valley.

The mean values of specific unit compaction and stress-compaction products for the two subareas suggest that the overall difference in apparent compressibility between the subareas has been reduced from fourfold for the specific unit compaction to $2 \frac{1 / 2}{2}$-fold for the stress-compaction products. Thus, in a general sense, it is concluded that roughly one-third of the compressibility difference between the subareas is the result of different prior total applied stresses. The remaining twothirds of the compressibility difference is ascribed to variations in lithologic and geologic factors.

Both the specific unit compaction and the stresscompaction products probably are anomalously high in the extreme northern part of the area because of the low values used for the thickness of the lower zone. Field evidence from compaction recorders indicates that the values of thickness of the perforated interval of the lower zone that are less than 700 feet are too low, but information is not available to indicate the true thickness of deposits subject to pore-pressure decline in the area. For example, the 1,000-foot depth for the deepest recorder at the Oro Loma site was selected as being representative of the deepest well perforations in the vicinity, but comparison of compaction and subsidence (see section "Cumulative Compaction at Multiple Compaction-Recorder Site," paragraph 7) shows that only 55 percent of the compaction was occurring in the depth interval $0-1,000$ feet in 1961-65. The other 45 percent of the compaction was occurring in the deposits below 1,000 feet, due to pore-pressure decline resulting from upward leakage or in response to large artesianhead declines in deep aquifers to the south. 


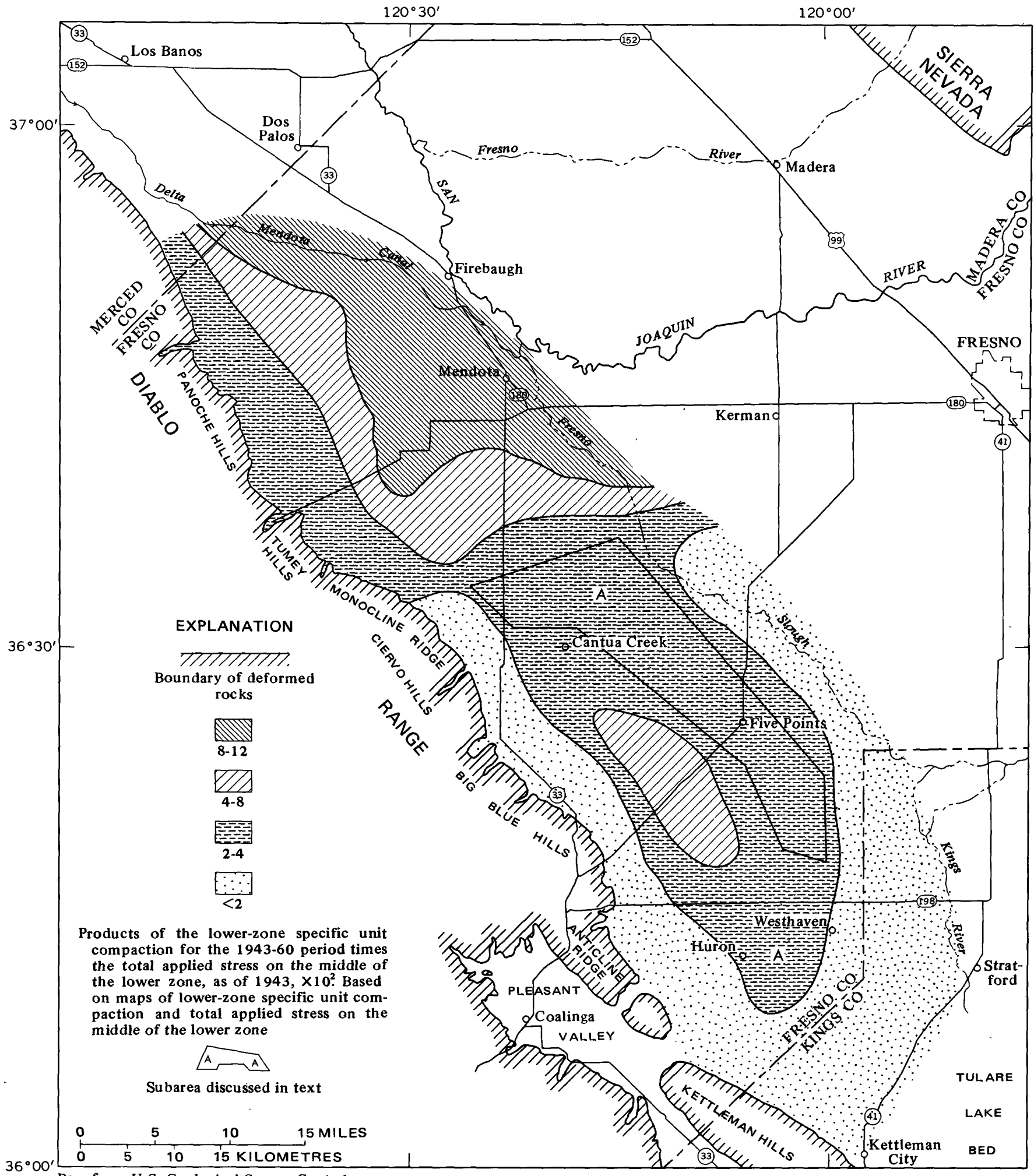

Base from U.S. Geological Survey Central

Valley map, 1:250,000, 1958

FiguRE 60.-Variations in stress-compaction products.

The problem of lack of knowledge about the maximum depth interval in which pore-pressure decline is occurring along the fringes of the study area does not invalidate the conclusions mentioned. Values of specific unit compaction of $5 \times 10^{-5}$ and stress-compaction products of $8 \times 10^{-2}$ (figs. 54,60 ) occur in the middle of 
the large area of intense subsidence southwest of Mendota where lower-zone aquifer-system thicknesses are 1,200 feet (fig. 55) - almost the maximum for the northern part of the area.

The removal of the effect of prior total applied stress in the central part of the area reveals several interesting aspects regarding the apparent compressibility of the deposits. Extremely low values of specific unit compaction (fig. 54) occur adjacent to the Big Blue Hills. By removing the effect of prior total applied stress on the deposits of this subarea, the values on the products map of figure 60 are no longer anomalously low, but are in the same range-1-2 $\times 10^{-2}$-as about half of the area south of the town of Cantua Creek. The removal of the anomaly adjacent to the Big Blue Hills suggests that the Pliocene marine deposits would be only slightly less compressible or would have about the same general compressibility as the Diablo alluvial-fan deposits south of the Huron-Westhaven area if the prior total applied stress had been equal.

If a map showing variation in ultimate specific unit compaction (the true compressibility of the deposits) could be prepared and the total effective stress were entirely the result of differences in prior effective stress, such a map would show little variation in the values of products in areas of uniform geologic and lithologic conditions. Although figure 60 utilizes transient specific unit compaction, little variation in the products occurs in those areas of similar geologic conditions.

In the central part of the study area (subarea A in figure 60 ), the stress-compaction products occur in a verry narrow range, despite large differences in total applied stress, as of 1943 . The work maps used in the construction of figure 60 show that the range of values for the products in this 100-square-mile subarea range only from 2.4 to $2.8 \times 10^{-2}$, even though the prior total applied stress on the middle of the lower zone ranges from 1,000 to 2,000 feet of water. The specific unit compaction for the same area decreases progressively with increasing total applied stress. The removal of the effect of prior applied stress eliminates the trend shown by the specific unit compaction and indicates that if it were not for differences in prior applied stress, the deposits within the subarea A would compact the same amount per unit of head decline. The situation described suggests that the deposits within subarea $\mathrm{A}$ in figure 60 should be similar geologically. Sierra flood-plain deposits are the dominant lower-zone type of deposit in all of subarea A. The western extension of the subarea north of the town of Cantua Creek coincides with the area of maximum western extent of thick Sierra flood-plain deposits and is north of the ancestral alluvial fans of Los Gatos and Cantua Creeks and south of the Panoche Creek fan. The Sierra flood-plain deposits intertongue with alluvial-fan deposits in the northwest and southeast corners of subarea A.

MEAN LITHOLOGY

Another geologic factor that might be responsible, in part, for the fourfold difference of specific unit compaction (fig. 54) in the northern and southern parts of the study area is the overall lithology of the deposits. The particle-size analyses of the samples from the core holes should be used with caution for such purposes because of the tendency of the coring equipment to recover the cohesive fine-grained deposits but not the incohesive coarse-grained deposits.

More complete and unbiased information can be obtained through electric-log studies of the lower zone. A resistivity map of the lower-zone deposits was made to evaluate the effect of lithologic variations on the compressibility of the deposits within the study area.

Three important types of data are available in all parts of the study area to make a lithofacies map based on electric logs. Abundant electric logs can be obtained readily. The salinity and chemical character of the lower-zone waters can be assessed as a result of a chemical sampling program made in 1951 (Davis and Poland, 1957). The water temperatures at the discharge points of the wells are determined at the times of each pump-efficiency test made by the Pacific Gas and Electric Co. Additional temperature information is available from the bottom-hole temperatures obtained at the times that the electric logs were made.

Thus, within the Los Banos-Kettleman City area abundant information is available to make a lithofacies map based on the mean resistivity of the lower zone, using electric-log data that are corrected for the effects of regional variations in salinity, chemical character, and temperature. Resistivity logs, instead of spontaneous-potential logs, were selected for the lithofacies study because of the lack of definition that is typical of the spontaneous-potential logs in this area. The mud used in drilling a new well usually is mixed with ground water from a nearby irrigation well; therefore, there is little contrast between the mud and formation resistivities, and the spontaneous-potential log approaches a straight line in which deflections do not occur for either the sand or clay beds.

The lateral resistivity log with a 19 -foot spacing between electrodes was used for the lithofacies study. The short- and long-normal resistivity logs were not used because small variations in resistivity were unimportant in a study of mean resistivity of the entire lower zone and because the lateral log minimizes the effect of drilling mud resistivity. Most of the drilling mud resistivities, at $38^{\circ} \mathrm{C}$, ranged from 3 to $6 \mathrm{ohm}$-metres, but the extremes in mud resistivities ranged from 1 to 20 ohm-metres. 
The temperature correction was based, in nearly all cases, on the temperature of the water being pumped from irrigation wells and ranged from 21 to $43^{\circ} \mathrm{C}$. The coolest water temperatures were for wells along Fresno Slough, and the hottest water temperatures were for wells that tap the sands of the Etchegoin Formation opposite the Big Blue Hills.

Two corrections had to be made for variations in the chemical character of the lower-zone water. A salinity correction was made, using standard charts provided by the Schlumberger Co. However, the Schlumberger charts are for $\mathrm{NaCl}$ solutions, and the typical lowerzone water is a sodium sulfate water (Davis and Poland, 1957). By using a procedure outlined by Schlumberger, correction factors were computed and applied to chemical analyses of lower-zone waters from different parts of the study area. The calculations showed that the resistivity of the lower-zone waters was only $0.72-0.76$, the resistivity of the $\mathrm{NaCl}$ solutions of comparable concentration. Therefore, a correction factor of 0.75 was applied to the dissolved solids values used in all the salinity corrections.

The salinity of the lower-zone water at each electriclog site was estimated from a map of the dissolved solids for the study area (Pt. 1, Bull and Miller, 1974, fig. 19). The estimated dissolved solids at the 110 electric-log sites ranged from about 700 to $2,000 \mathrm{mg} \mathrm{l}^{-1}$ (milligrams per litre). An NaCl salinity of $1,000 \mathrm{mgl}^{-1}$ was used as a standard for the study.

The mean resistivity of the lower zone based on electric logs, and corrected to $38^{\circ} \mathrm{C}$ and $1,000 \mathrm{mg} \mathrm{l}^{-1} \mathrm{NaCl}$ salinity, is shown in figure 61 . A general guide to the lithologies of the resistivities can be made by comparing the particle-size analyses and electric-log corrected resistivities at several core-hole sites. Thick clay beds such as the Corcoran or the fine-grained beds associated with the Etchegoin Formation have corrected resistivities of about 3-4 ohm-metres (values that may be too low if the pore water in the clays has a higher salinity than the water pumped by the wells). At the other extreme, clean well-sorted coarse-grained sand beds have a corrected resistivity of $20-25 \mathrm{ohm}$-metres. Thick beds consisting of fine- to coarse-grained sand have a corrected resistivity of $1 \dot{0}-15 \mathrm{ohm}$-metres. Silts and clayey sands have corrected resistivities of about 4-10 ohm-metres. The low mean resistivities that prevail throughout most of the study area are indicative of the clayey nature of most of the compressible deposits that have compacted to cause the large amounts of subsidence within the area. The lithofacies map also shows why 800-2,000 lineal feet of casings have to be perforated in most of the wells in order to obtain sufficient water for irrigation.

The mean resistivity of the lower zone shown in figure
61 reveals some interesting lithofacies variations within the study area. Although fine-grained deposits occur throughout most of the area, the deposits in the northern part of the area appear to be less clayey than the deposits in the southern part of the area. The central part of the area appears to have deposits with an intermediate amount of clay.

In four parts of the study area, the lithofacies map shows a strong correlation between increasing resistivity (coarser deposits) and the areas where sediments were introduced into the area during the course of deposition. Coarse-grained deposits are most common where Panoche and Los Gatos Creeks and the San Joaquin and Kings Rivers entered the study area. The bands of equal range in resistivity are concentric about the points of discharge into the San Joaquin Valley of the ancestral streams of Panoche and Los Gatos Creeks.

The lines of equal sums of the determined constituents (approximately the dissolved solids) also are concentric about the ancestral mouths of Panoche, Los Gatos, and Cantua Creeks (Pt. 1, Bull and Miller, 1974, fig. 19), which might suggest, at first thought, that an incomplete salinity correction was made for parts of the area in preparing figure 61 . This is not the case. Chemical analyses were available for lower-zone wells throughout the study area. Furthermore, the lines of equal mean resistivity (fig. 61) cut across the lines of equal dissolved solids (Pt. 1, Bull and Miller, 1974, fig. 19). For example, in figure 61 , the 7.5 mean resistivity line near the town of Cantua Creek passes through areas where the dissolved solids for lower-zone waters ranges from less than $800 \mathrm{mg} \mathrm{l}^{-1}$ to more than $2,000 \mathrm{mg}$ $1^{-1}$. The 10.0 mean resistivity line opposite the mouth of Panoche Creek passes through areas that range from less than 1,000 to more than $2,000 \mathrm{mg}^{-1}$ dissolved solids for the lower zone. It is concluded that the sources of pre-Corcoran coarser grained deposits from the Diablo Range were also the source of younger waters of high dissolved solids that largely replaced the waters originally contained in the deposits.

The results of particle-size analyses of core-hole samples agree with the lithofacies map, even though a larger proportion of finer grained than coarser grained deposits were recovered in the coring process. Variation in mean particle size with depth for the deposits cored below the Corcoran at the Mendota and Huron core sites is shown in figure 62. The lithofacies map in figure 61 indicates that the lower-zone deposits at the Mendota site are slightly coarser than the deposits at the Huron site. The particle-size data shown in figure 62 show that many of the cored sediments at the Mendota site are as fine grained as those at the Huron site, but samples with mean particle sizes of more than 125 microns are much more common in the Mendota core than in the Huron 


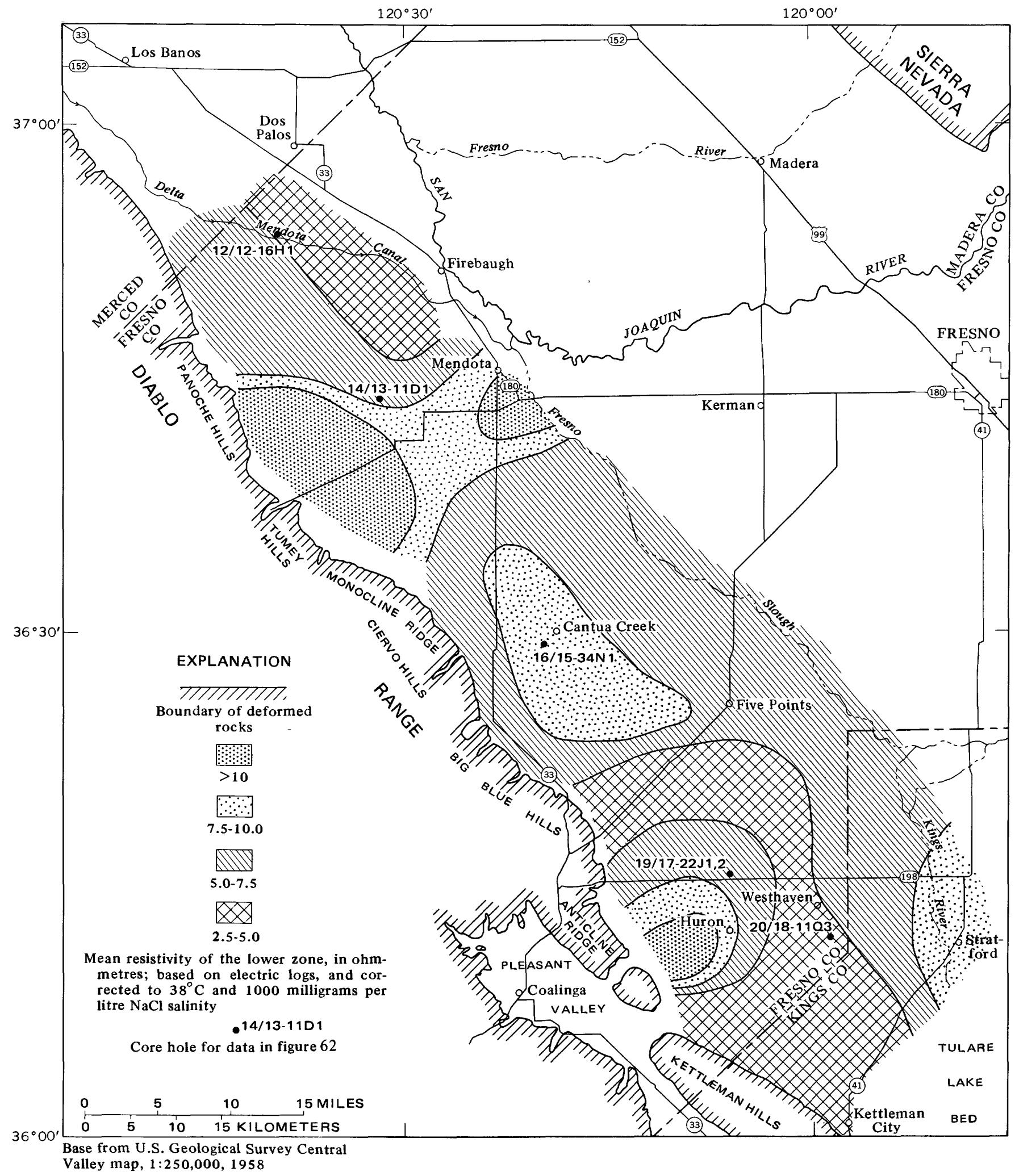

FIGURE 61.-Lithofacies map based on the mean corrected resistivities of the lower zone

core. Meade (1967, p. 12) concluded that "the sediments $\mid$ well sorted, and less skewed than the sediments from from the Huron core are generally finer grained, less $\mid$ the Mendota core." 


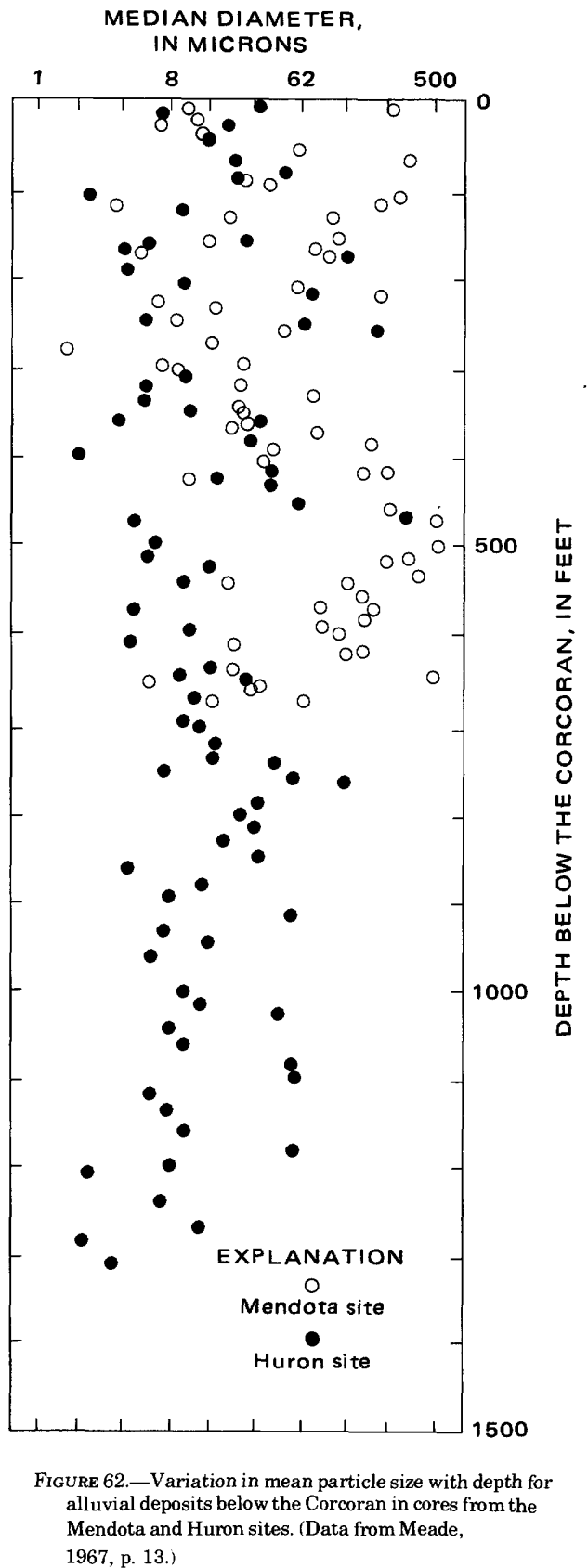

A comparison was made between the overall lithology (mean resistivity) and the stress-compaction products for the lower zone. Because of the marked difference in apparent compressibility in the northern and southern parts of the area, the northern-area data were plotted separately from the data for the rest of the area. Data for all points north of township 16 (fig. $63 A$ ), for which the products shown in figure 60 exceed $2.5 \times 10^{-2}$ (from work map), are plotted in figure $63 \mathrm{~A}$, and data for the points for the central and southern parts of the area are plotted in figure $63 B$.

The large amounts of scatter in figures $63 A$ and $63 B$ show that variation in gross lithology, as indicated by

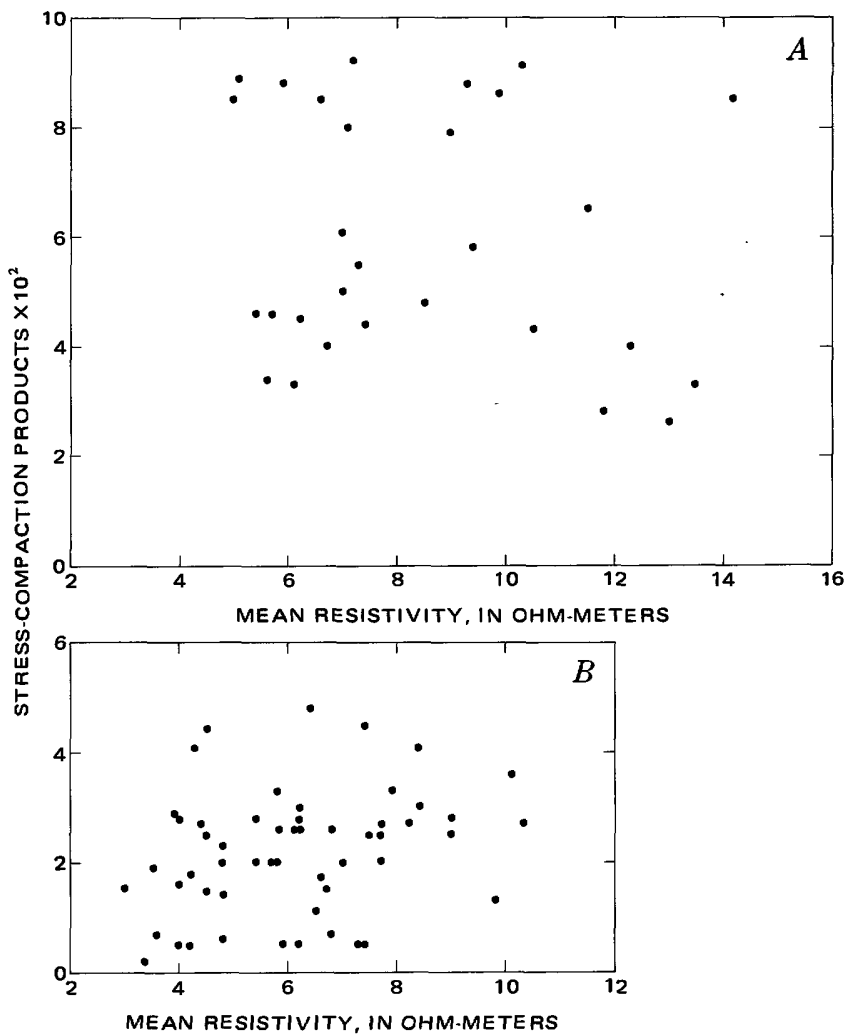

Figure 63.-Relation of mean corrected resistivity to the product of specific unit compaction and total applied stress, lower zone. $A$, North of township $16 . B$, South of township 15.

the mean resistivity of the lower zone, is not important in causing the fourfold variation in specific unit compaction from 1943 to 1960 between the northern and southern parts of the area (fig. 54) or the twofold variation in the stress-compaction products (fig. 60). The deposits in the northern part of the area are slightly less clayey than the deposits in the southern part of the area, but the twofold differences in the apparent compressibility of the deposits in the two subareas cannot be explained by variations in overall lower-zone lithology. Mean lithology may be highly significant in evaluating ultimate compaction amounts, but where aquitards have large residual excess pore pressures other factors, such as the thickness of a bed of a given lithology, are more important than average lithology.

\section{Source And Mode Of Deposition}

The third geologic factor to be considered as a possible cause of the variation in specific unit compaction in the northern and southern parts of the study area is the relation of the sources of the lower-zone deposits, and their modes of deposition, to the apparent compressibility of the deposits. Different types of deposits intertongue with each other in much of the area, but the deposits can be grouped in three classes. The three categories of deposits shown in figure 64 are largely from Part 1 (Bull and Miller, 1974, fig. 16). 


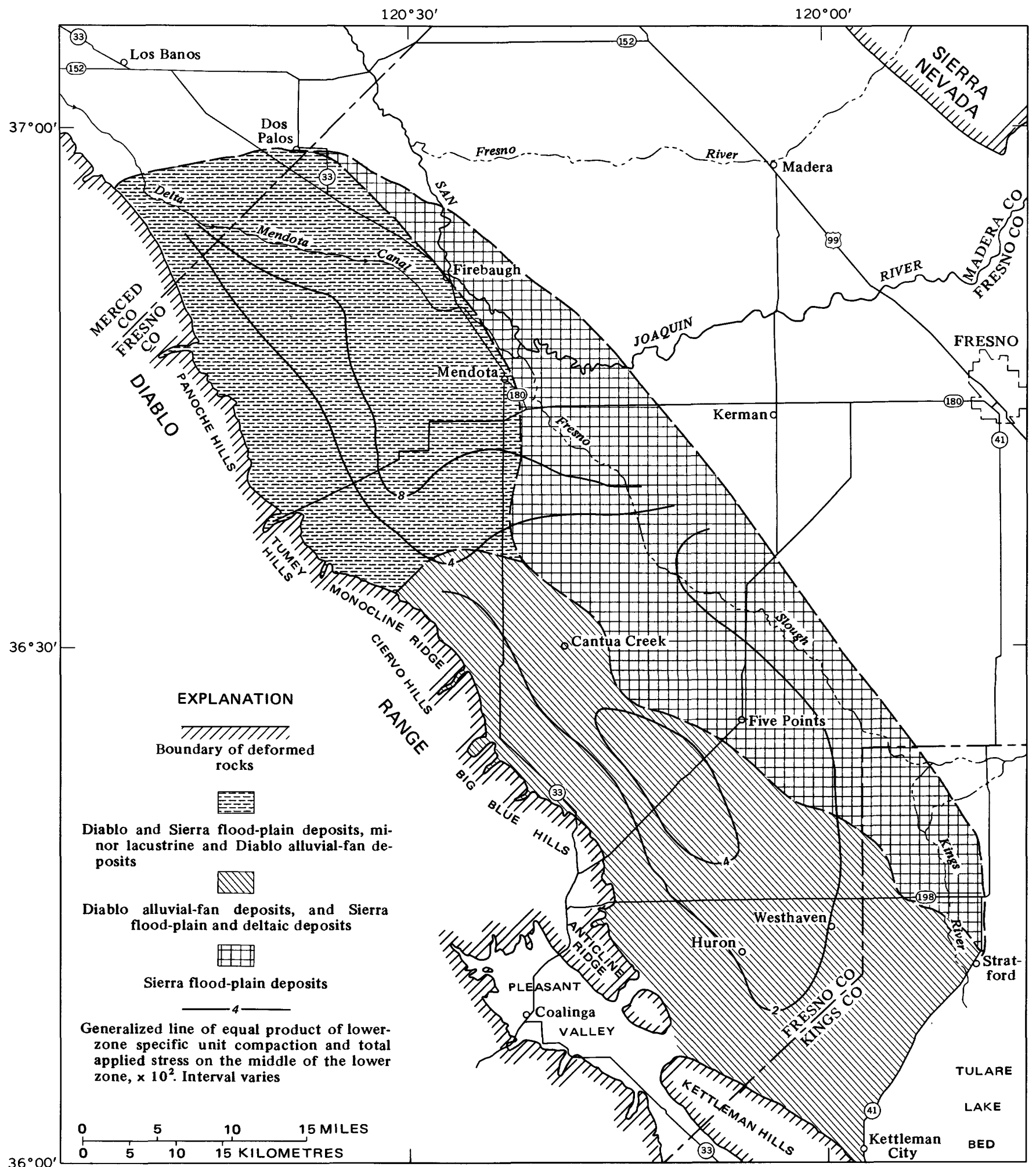

Base from U.S. Geological Survey Central

Valley map, $1: 250,000,1958$

FIGURE 64.--Relation of stress-compaction products to the sources and modes of deposition of the lower-zone deposits.

The northern area of Diablo and Sierra flood-plain $\mid$ Diablo flood-plain deposits predominate near the Diablo deposits has the maximum apparent compressibility, as Range and the proportion of Sierra flood-plain deposits indicated by the lower-zone stress-compaction products. Increases toward the east. East and north of Mendota, 
flood-plain deposits from the San Joaquin River constitute virtually all the lower-zone deposits tapped by wells.

In the southern part of the study area, most of the lower-zone deposits consist of alluvial-fan deposits. Near the Diablo Range, virtually all the lower zone consists of alluvial-fan deposits, except in those areas of pumpage from the Pliocene marine deposits. Farther to the east, Sierra flood-plain and deltaic deposits become increasingly more important in the basal part of the lower zone. Toward the north, Diablo and Sierra flood-plain deposits become progressively more common. In the vicinity of the town of Cantua Creek, alluvial-fan, lacustrine, and deltaic deposits, as well as marine sediments, are present. The unit that includes alluvial-fan deposits has only half the apparent compressibility (as indicated by the stress-compaction products) of the flood-plain deposits in the northern part of the area.

The Sierra deposits show considerable variation in apparent compressibility. South of the town of San Joaquin, the apparent compressibility of the lower-zone deposits, as indicated by the products map, ranges from less than 1 to about $3 \times 10^{-2}$-an apparent compressibility that is less than the compressibilities in either of the two subareas adjacent to the Diablo Range. Most of the deposits in the southern part of the belt of Sierra flood-plain and deltaic deposits were deposited by the Kings River.

In the northern part of the belt of lower-zone Sierra flood-plain deposits, the apparent compressibilities tend to be about the same as for the Diablo flood-plain deposits to the west. Most of the Sierra flood-plain deposits in this part of the subarea were deposited by the San Joaquin River. The lithofacies map in figure 61 indicates that the lower-zone deposits in the vicinity of Mendota have a higher resistivity (less clay) than the lower-zone deposits of the Kings River farther south.

Prior discussions concluded that about one-third the fourfold difference in the values of specific unit compaction in the southern and northern parts of the study area was the result of actual differences in compressibility due to the lesser prior applied stress in the northern part of the study area. The coincidence between the area of Diablo and Sierra flood-plain deposits and the area of high values of the stress-compaction products in the northern part of the area indicates a strong correlation between genetic class of deposits and compaction per unit head decline for stresses applied during the 1943-60 period.

The relation of the apparent compressibility (stresscompaction products) of the lower zone to the genetic classes of deposits is shown along a longitudinal profile of the study area in figure 65. Maximum values of ap-

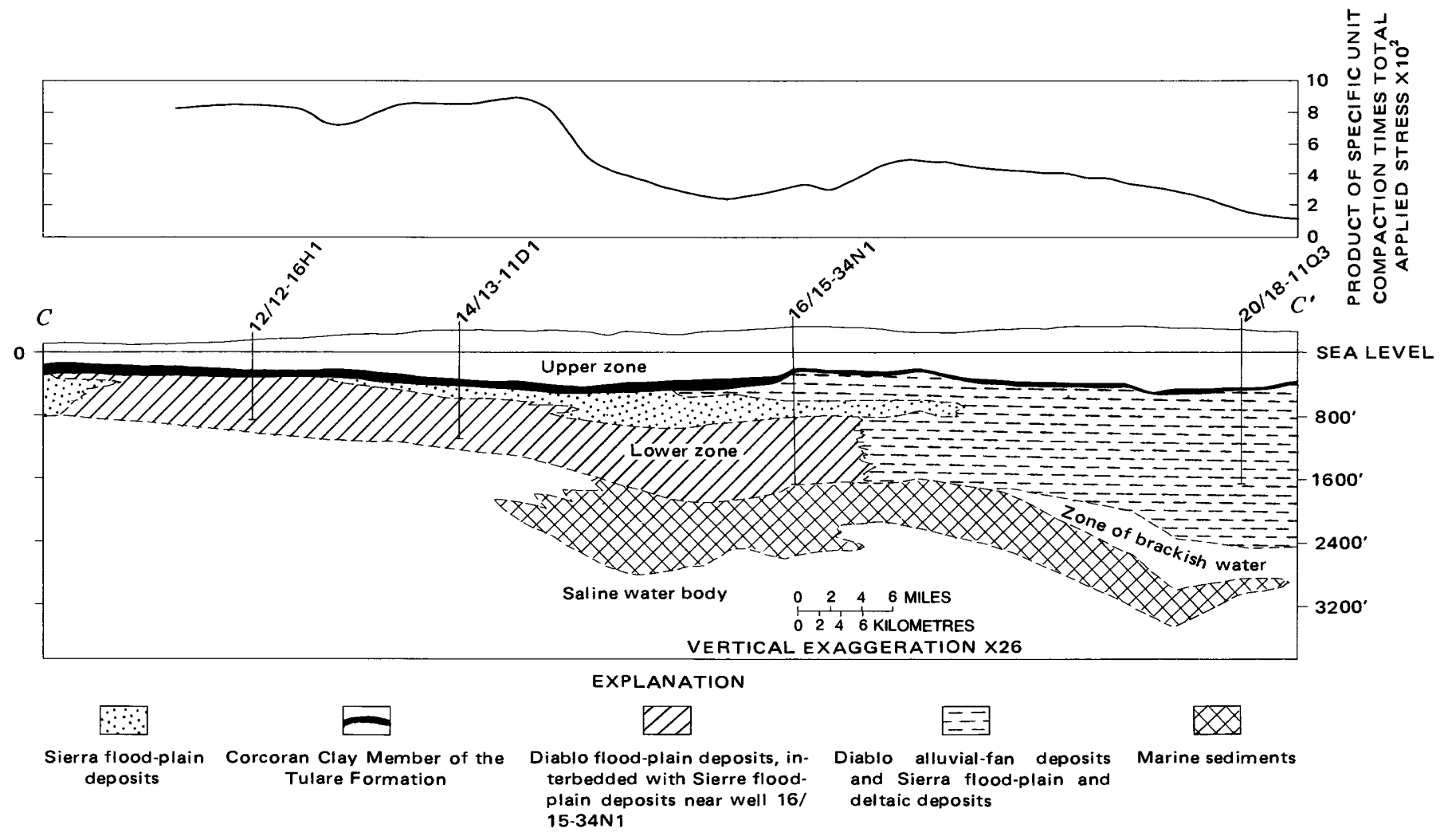

FIGURE 65.-Relation of stress-compaction products to types of lower-zone deposits. 
parent compressibility occur in the northern part of the area, where Diablo flood-plain deposits constitute nearly all the lower zone along the line of section.

The apparent compressibility decreases in the central part of the area. Stress-compaction products in the northern part of the area are about $8 \times 10^{-2}$, but in the central part of the area, the products are only about $3 \times 10^{-2}$. The marked decrease of stress-compaction products of the deposits in the central part of the area coincides with marked changes in the source and depositional environment of the deposits tapped by wells. Coarse-grained Sierra flood-plain deposits constitute more than 400 feet of the lower zone (fig. 65), and below the Sierra flood-plain deposits are intermixed Sierra and Diablo flood-plain deposits. In addition, the Pliocene marine deposits of the Etchegoin and San Joaquin Formations are heavily pumped to the west. The increase in the proportion of sand, with increasing proportion of Sierra flood-plain deposits and the inclusion in the section of the deeply buried partly consolidated Pliocene marine deposits, account for the decrease in apparent compressibility in the central part of the study area.

As much as 20 feet of subsidence had occurred in the central part of the area as of 1966 , but figure 65 shows that the large amounts of subsidence that have occurred are not the result of large values of unit compaction per unit change in applied stress during a given period of time such as the 1943-60 period. Instead, the large amounts of subsidence that have occurred south of Cantua Creek are the result of large pore-pressure declines in more than 2,000 feet of lower-zone deposits.

Southeast of well 16/15-34N1, the apparent compressibility shown in figure 65 increases to about $5 \times 10^{-2}$. Deposits from many sources occur in this area also, but Sierra flood-plain and deltaic deposits make up much of the lower zone. Diablo alluvial-fan deposits overlie the Sierra deposits, and the marine littoral and estuarine deposits underlie the Sierra deposits. In contrast to the deltaic deposits shown in figure 51, the Sierra deltaic deposits in this part of the area have extensive sand beds. The marine sediments are not tapped by wells along the line of section south of the northernmost limit of the lens of brackish water.

In the southern part of the area, wells are able to obtain sufficient quantities of water without having to tap the Pliocene marine section or the fresh-waterbearing deposits in the basal part of the overlying Tulare Formation. Although these deeper deposits contain fresh water, as indicated in figure 65 , wells in the southern part of the area generally are not perforated more than 100 feet below the bottom of well 20/18-11Q3 (fig. 65 ). The alluvial-fan deposits derived from the Diablo Range predominate within the interval tapped by irri- gation wells along the line of section. The proportion of alluvial-fan deposits constituting the lower-zone deposits increases to the southeast and is coincident with a decrease in apparent compressibility from 4 to $2 \times 10^{-2}$.

Variation In Excess Pore Pressures

Several lines of evidence indicate that the various genetic types of deposits differ in their ability to retain excess pore pressures because of the characteristics of their source materials and their modes of deposition. The following summary indicates that the Diablo alluvial-fan deposits should be slower to attain porepressure equilibrium after a given head decline than the Diablo and Sierra flood-plain deposits:

Evidence based on laboratory tests of core-hole samples

1. Particle-size analyses of $\mathbf{1 4 5}$ samples from alluvialfan deposits and 95 samples from flood-plain deposits indicate mean clay contents of 28 percent for the alluvial-fan samples and 22 percent for the flood-plain samples.

2. The alluvial-fan deposits are more poorly sorted than the flood-plain deposits (Meade, 1967, p. 12).

3. Mean vertical permeabilities for 23 samples, as determined by consolidation tests in the load range of $400-800 \mathrm{lb} \mathrm{in}^{-2}$ indicate that the fine-grained beds of the fan deposits are less permeable than the fine-grained beds of the flood-plain deposits. In gallons per day per square foot, the mean permeability values were 1.7 for the fan deposits and 5.7 and 4.0 for the Diablo and Sierra flood-plain deposits.

4. Mean values of the coefficient of consolidation, $c_{v}$, for 14 samples tested in the load range of $400-800 \mathrm{lb}$ in $^{-2}$ indicate that the fine-grained beds of the alluvial-fan deposits consolidate at a much less rapid rate than the fine-grained beds of the flood-plain deposits. The mean values of $c_{v} \mathrm{ft}^{2} \mathrm{yr}^{-1}$ were 8 for the fan deposits and 28 and 21 for the Sierra and Diablo flood-plain samples.

$$
\text { Field evidence }
$$

1. Study of the micrologs of the different types of deposits shows that the Diablo alluvial-fan deposits generally have thicker beds of fine-grained material than the flood-plain deposits. Weighted mean bed-thickness factors of aquitards penetrated by the four Inter-Agency Committee core holes were 24 for the alluvial-fan deposits and 14 for the flood-plain deposits.

2. Mean well yield factors (Pt. 1, Bull and Miller, 1974, fig. 16) for the types of deposits range from 1 to 4 for fan deposits and are 9 and 11 for Diablo and Sierra flood-plain deposits. The slow water expulsion rate from the fine-grained beds of the alluvial-fan deposits is, in part, responsible for the perforated 
intervals of 1,200-1,600 feet and drawdowns of 100-120 feet in the southern part of the area. In contrast, the wells of similar yield in flood-plain deposits commonly are perforated for 600-1,000 feet and have drawdowns of 40-60 feet.

Thus, conditions in the alluvial-fan aquitards in the southern part of the area have been favorable for development of large residual excess pore pressures and high values of ultimate specific unit compaction. The same conditions also are responsible, in part, for the lower apparent compressibilities (stress-compaction products) in the alluvial-fan deposits than in the flood-plain deposits during the 1943-60 period.

The hypothesis of more rapid dissipation of excess pore pressures in the northern subarea can be checked by examining the changes in compaction rates at four compaction-recorder sites. The decrease in mean daily compaction rates at the four sites is shown by Bull and Poland (Part 3, fig. 40, 1974). The mean-dailycompaction-rate plots may be represented by a general exponential equation of the type

$$
y=c e^{m x},
$$

in which $c$ and $m$ are determined by the data for each site. Taking the Cantua site data as an example, the equation for the plot of mean daily compaction rate $(y)$ and the time since mid-1961 in years $(x)$ is

$$
y=0.0028 e^{-0.096 x} \text {. }
$$

Computation of the values of $m$ for the four regression lines for the sites gave the following results: Cantua site, -0.096 ; Mendota site, -0.21 ; Westhaven site, -0.091 ; and the Oro Loma site, -0.18 . Although these values of $m$ are approximations, a rough twofold contrast in $m$ values is apparent for the compactionrecorder sites in the northern and southern subareas.

The contrasts between the northern and southern areas regarding aquitard thickness and mean daily compaction rates imply that, as of 1967 , larger excess pore pressures for a given head decline existed in the lower-zone deposits of the southern than the northern subarea. The magnitudes of the above contrasts is about the same as the magnitude of contrast in stresscompaction products (fig 60).

Mean daily compaction rates might also be affected by the proportions of aquitards in the lower zone. The core-hole sites had the following percentages of aquitards in the lower zone: Oro Loma, 41; Mendota, 23; Cantua, 69; and Huron, 55. The means for the two pairs of core holes in the northern and southern subareas are 32 and 62 percent, respectively. (The difference between these means is significant at the 0.88 probability level.) Thus, an inverse relation apparently exists between the compaction rates and the proportions of the lower zone comprised of aquitards. This further underscores the effect of aquitard thickness on recorded compaction for an aquifer system that does not have a steady-state pore-pressure distribution.

It is concluded that the source and environment of deposition is at least as important a geologic factor as the prior applied stress in determining the rate and amount of subsidence within the Los Banos-Kettleman City area. The combination of extensive permeable sand beds and intercalated clayey beds that generally do not exceed 8 feet in thickness provide an ideal geologic environment for the rapid expulsion of large amounts of water from the fine-grained beds to cause the large amounts of subsidence during the 1943-60 period. One-third of the difference between the apparent compressibility (specific unit compaction) in the northern and southern parts of the area is real and is due to differences in prior total applied stress as of 1943. The other two-thirds of the difference is indeed only apparent and is attributed chiefly to hydraulic and petrologic differences between genetic types of deposits that affect the rate of expulsion of water from aquitards upon increase in applied stress. The effects of the mean lithology of the lower zone are not considered nearly as significant as either the effect of total applied stress or bed thickness of the sediments laid down under different modes of deposition.

\section{DISTRIBUTION OF WELL-CASING FAILURES}

Studies of well-casing failures have provided useful information about the distribution of casing breaks in the different types of deposits. Figure 66 shows the variation of casing-failure occurrences for the upper and lower zones and for the various types of deposits. In the upper zone, most of the casing failures have occurred in the basal part of the zone, where pore-pressure declines have been greatest. In general, the casing failures are most abundant in the lower zone because, as a unit, it has undergone more compaction than the upper zone. West of the Corcoran in the southwestern part of the area, the unit casing-failure ratio is intermediate between the ratios for the upper and lower zones where the Corcoran is present.

The Diablo alluvial deposits have an overall casing failure ratio that is similar to that of the Corcoran. The Sierra sands have the highest casing-failure ratio of any of the types of deposits. The abundant casing failures opposite the Sierra sands probably are not indicative of a higher unit compaction in sands than in clays. They may be related in part to the removal of sand adjacent to the casing during the course of pumping. Removal of the sand providing lateral support for the well casing would provide potential weak sections that could be ruptured as a result of compressive stresses that were caused by 
compaction of overlying and underlying fine-grained deposits.

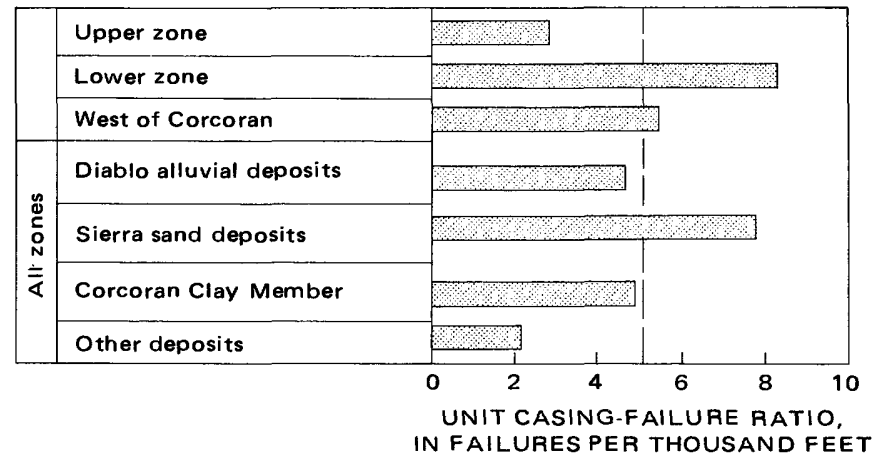

FigURE 66.-Relation of well-casing failures to hydrologic unit and type of adjacent deposit. (From W. E. Wilson, written commun., April 1968.)

\section{SUMMARY AND CONCLUSIONS}

Changes in the altitude of the land surface in the Los Banos-Kettleman City area have been caused by compaction due to wetting of moisture-deficient alluvial-fan deposits, withdrawal of petroleum, and tectonic movements, but have been caused mainly by ground-water withdrawal.

Two main sources of vertical-control data were used. The Geological Survey made surveys for detailed topographic maps of the entire area during the 1920's and in 1955. Comparison of these maps provides regional subsidence information prior to 1955 . Although the Coast and Geodetic Survey levelings provide valuable information as early as 1933, the establishment of a levelline network in 1955 and subsequent relevelings to specifically evaluate land subsidence provided a means of obtaining detailed information about the extent, magnitude, and rate of subsidence.

During the last million years, parts of the adjacent Coast Ranges have been elevated more than 2,000 feet, and parts of the San Joaquin Valley have subsided about 1,000 feet as a result of tectonic movements. Tectonic movements are continuing today, but at very slow rates compared with the rate of manmade subsidence. The amounts of intermittent uplift of parts of the mountain front are small and are superimposed on long-term subsidence due to nontectonic causes. About 0.1 foot of net apparent uplift of the crest of Anticline Ridge occurred between 1962 and 1963.

Subsidence due to the withdrawal of petroleum is minor in extent and magnitude and occurs, in part, in those areas of subsidence due to withdrawal of ground water. Bench marks on Anticline Ridge that are set in formations older than the fresh-water-bearing formations indicate about 0.25 foot of net subsidence due to withdrawal of petroleum from the Coalinga oil field since 1943 .
Near-surface subsidence occurs within about 7 percent of the areas affected by subsidence due to artesian-head decline. About 130 square miles have subsided or would subside if irrigated. Subsidence of 3-10 feet is common, and 10-15 feet of subsidence has occurred locally.

Near-surface subsidence results from the compaction of deposits by an overburden load as the clay bond supporting the voids is weakened by water percolating through the deposits for the first time since burial. The amount of compaction due to wetting is dependent mainly on the overburden load, natural moisture conditions, and the type and amount of clay in the deposits. The amount of compaction increases with an increase in the overburden load, but most of the near-surface subsidence has been caused by compaction in the upper 200 feet of deposits. For compaction due to wetting to occur, the alluvial-fan deposits must remain moisturedeficient after burial, and the deposits must have sufficient clay so that they undergo a decrease in strength when water percolates through them for the first time.

Both the magnitude and extent of subsidence due to artesian-head decline are greater than near-surface subsidence. The pattern of subsidence is an elongate oval, in which the area (as of 1966) that had subsided more than 10 feet was 70 miles long. More than 1 foot of subsidence had occurred in 2,000 square miles of the Los Banos-Kettleman City area and the adjacent areas east of the trough of the valley. Maximum subsidence of 26 feet occurred southwest of Mendota between 1920 and 1966 , and the 'maximum subsidence rate of a bench

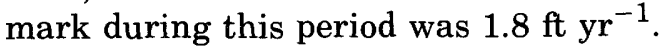

Intense subsidence occurred first in the northern part of the area. By 1943, as much as 10 feet of subsidence had occurred west of Mendota, but less than 2 feet of subsidence had occurred in most of the southern part of the area. The area of intense subsidence expanded after the middle 1940 's as a result of rapid agricultural development during and after World War II. By 1963, more than 20 feet of subsidence had occurred in both the northern and southern parts of the area.

During the $1959-63$ period, 480 square miles were subsiding more than $0.5 \mathrm{ft} \mathrm{yr}^{-1}$, and 63 square miles

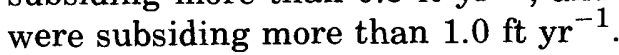

Histories of subsidence rates are highly variable in the different parts of the area. In general, subsidence rates were $0.1-0.8 \mathrm{ft} \mathrm{yr}^{-1}$ greater during the 1959-63 period than during the $1943-53$ period. The area between Los Banos and Mendota was the only large area in which the subsidence rate decreased between the two periods. Subsidence rates increased until 1954, when deliveries of water from the Delta-Mendota Canal reduced the amount of ground water pumped, and have 
decreased since then. Subsidence rates have increased steadily at Mendota and to the northeast, and south of Huron until 1963. In the area between Kettleman City and Fresno Slough, years of little or no subsidence occur between years of as much as 0.4 foot of subsidence.

Since the middle 1950's, subsidence rates have remained fairly constant or have decreased slightly in most of the area. During the 1963-66 period, only a few

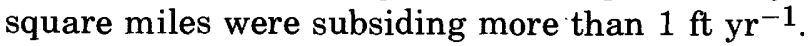

Compaction gages, consisting of anchors set near the base of the fresh-water-bearing deposits and connected to the land surface with $1 / 8$-inch cables inside well casings, have been measuring as much as 99 percent of the compaction that is causing the subsidence. The proportion of the subsidence that is being measured is decreasing at most compaction-recorder sites, indicating that compaction is occurring at greater depths than previously. At the Oro Loma site, the percent of subsidence that is being measured by the 1,000-foot compaction recorder has decreased from about 90 to 55 percent. At the Cantua site, the percentage has decreased from 99 to 78 percent.

Seasonal variations in the rate of compaction occur at most sites, but are not well defined at some sites such as the Cantua site. Subsidence rates tend to be greatest during the late winter and during the summer-the times of maximum demand for irrigation water from the ground-water reservoir.

The use of several compaction recorders at one site provides a means of measuring the unit compaction in the intervals between the depths at which the anchors are set. Annual unit compaction has varied from zero for the 350-500-foot depth interval at the Oro Loma site to $1.2 \times 10^{-3}$ foot per foot per year for the 503-703-foot depth interval at the Cantua site.

Variation of unit compaction with depth for the Los Banos-Kettleman City area is largely the result of two components - the decrease in compressibility of the deposits with depth because of the increase in prior effective overburden load and the variations in the amounts of head decline that have occurred as a result of pumping. Perforated-interval data suggest that the amounts of head decline increase with depth to about 200 feet below the Corcoran and then remain about constant or decrease slightly with further increase in depth. The casing-failure data indicate that unit compaction increases to a depth of about 200 feet below the Corcoran because the trend of greater head decline with increasing depth dominates over the decreasing compressibility of the deposits with increasing depth. Below a depth of about 200 feet below the Corcoran, the effects of decreasing compressibility of the deposits dominate, and unit compaction decreases with increasing depth.

Water- and oil-well casings are being shortened in amounts about equal to the amount of compaction of the deposits, even if they are encased in cement. For wells ranging in size from 4 to 13 inches that are not gravelpacked, resistance to compaction decreases with increasing casing diameter. Increased protrusion of the well casings above the land surface is common, but is less than 10 percent of compaction for most water wells. The use of tops of well casings as subsidence bench marks and the measuring of increased protrusion to obtain amounts of compaction are not reliable unless the proportions of casing shortening and increased casing protrusion are known.

Comparison of the subsidence of well bench marks and reference bench marks 17-193 feet from the wells indicates that casings of pumped wells subside more than reference bench marks despite increased protrusion of the well casings. Maximum compaction occurs at, or near, pumping wells because they are point sources of maximum applied stress.

Compaction has damaged or destroyed hundreds of well casings where subsidence rates have been more than 0.5 foot per year for more than $5-10$ years. Wells in areas where subsidence rates are less than $0.5 \mathrm{ft} \mathrm{yr}^{-1}$ commonly last $10-20$ years, but repairs of well casings in such areas of lesser subsidence rate are common.

Most of the compaction is occurring below the Corcoran; only 5-30 percent of the compaction occurs above the Corcoran in most of the area. As much as 30-40 percent of the compaction occurs above the Corcoran in the southern part of the area.

The rates, amounts, and distribution of subsidence within the Los Banos-Kettleman City area are highly dependent on regional variations of geologic factors influencing the compaction of unconsolidated deposits. The poorly sorted and clayey nature of many of the sands tends to increase the compressibility of the sands within the study area. The presence of large freshappearing mica flakes in the sands derived from the Sierra Nevada increases the potential for inelastic compaction and the potential for an elastic expansion or compaction of the aquifers.

The deposits of the study area contain about 20 percent of clay-size material, which consists mainly of montmorillonite with calcium as the principal adsorbed cation. Except for the uppermost 300 feet of the Oro Loma core, about 7 parts out of 10 of the clay minerals are montmorillonite (Meade, 1967). The presence of large amounts of montmorillonite clay adds greatly to the compressibility of the deposits upon change in effective stress, as compared with kaolinite or illite clays.

In general, the younger deposits are less consolidated than the older deposits. The partly consolidated nature of the older deposits may be due to large prior overburden loads, but time also has been important in 
influencing the degree of compaction or cementation of the deposits. The Pliocene marine deposits are noticeably more consolidated than the Pleistocene deposits. The Pliocene clayey deposits, instead of being plastic, are sufficiently brittle that samples will break when struck with a hammer. The Pliocene sandy deposits, instead of being loose, are sufficiently cemented that they are cohesive, but friable.

The specific unit compaction for the 1943-60 period was determined for the lower zone. The specific unit compaction was based on (1) the subsidence during the period, (2) the proportions of post-1960 lower-zone compaction in the various parts of the study area, (3) the change in applied stress on the lower zone as a result of change in lower-zone artesian head and change in the position of the water table, and (4) the thickness of the lower-zone deposits that have undergone large head decline.

The most important aspect of the lower-zone specific unit compaction is that the values of specific unit compaction are about four times larger in the northern than in the central and southern parts of the area. The geologic factors that were evaluated to determine the causes of areal variation in specific unit compaction were prior total applied stress, mean lithology, and source and mode of deposition of the different genetic types of deposits.

The applied overburden load that was computed was the total applied stress on the middle of the lower zone at the beginning of the 1943-60 period. The components of the total applied stress included (1) the buoyant weight of saturated deposits, (2) the geostatic weight of deposits and contained water above the water table, and (3) the seepage stresses caused by head differentials resulting chiefly from artesian-head decline. The component of total applied stress on the middle of the lower zone that was present in 1943 owing to the buoyant weight of saturated deposits ranged from 800 to 1,800 feet of water for most of the area, but locally the applied stress resulting from this component was less than 600 feet or more than 2,000 feet.

The lack of buoyant support for the deposits above the water table and the weight of water contained in the unsaturated deposits were responsible for an additional load in 1943 that was equal to 50-200 feet of water in most of the area. By 1943, artesian-head decline had lowered the potentiometric surface of the lower zone below the water table in all parts of the area. The result was an increase in applied stress on the lower zone. As of 1943 , seepage stresses of $100-200$ feet of water were being applied to the lower zone in most of the study area. The three components of applied stress resulted in a total applied stress on the middle of the lower zone as of 1943 of $600-2,200$ feet of water, but in most of the area the range of total applied stress was 1,000-1,800 feet of water.

The effect of prior total applied stress on lower-zone specific unit compaction for the 1943-60 period was largely removed by multiplying specific unit compaction by total applied stress. The resulting product is an apparent compressibility of the deposits. By removing the effects of prior applied stress about a third of the fourfold difference in specific unit compaction between the northern and southern parts of the area was removed. Removal of the effects of prior stress eliminated the area of anomalously low values of specific unit compaction adjacent to the Big Blue Hills. In a 100 -square-mile area underlain chiefly by Sierra flood-plain deposits, the removal of the effects of prior total applied stress that ranged from 1,000 to 2,000 feet resulted in almost uniform stress-compaction products that ranged only from 2.4 to $2.8 \times 10^{-2}$.

It is concluded that prior applied stress is an important factor in determining the compressibility of a deposit of a given lithology in response to unit increase in effective stress. Compaction-recorder data at the Westhaven site substantiate this conclusion. Values of unit compaction for the alluvial-fan deposits are larger at shallower depths than at greater depths, where much of the upper zone has undergone head declines of similar magnitude to those in the lower zone.

Variations in the overall lithology of the lower zone were evaluated by making a lithofacies map based on the mean electric-log resistivities corrected to $38^{\circ} \mathrm{C}$ and $1,000 \mathrm{mg} \mathrm{l}^{-1} \mathrm{NaCl}$ salinity. The lithofacies map indicates that the deposits in the northern part of the area are coarser grained than the deposits in the southern part of the area. The low resistivities that prevail in most of the study area confirm the presence of abundant fine-grained material noted in core samples. The coarser grained deposits in the lower zone are most common where the ancestral streams of Panoche and Los Gatos Creeks and the San Joaquin and Kings Rivers entered the study area.

Plots of mean resistivity and stress-compaction products of the lower zone have a large degree of scatter. A relation between mean lithology and apparent compressibility does not exist. Although laboratory tests indicate that clays are more compressible than sands, a parallel relation could not be demonstrated for the amounts of compaction that occurred for different mean lithologies between 1943 and 1960 in response to the increase in applied stress during the same period. Apparently, insufficient time was available during the period for large amounts of compaction to occur in those sections of the lower-zone containing large amounts of clay. The areas having large amounts of sand are interpreted as having compacted rapidly, but the total 
amount of compaction was less than for areas having intermediate amounts of sand.

Consideration of the mode and source of deposition of the lower-zone deposits (Miller and others, 1971, p. 25-33) revealed that the northern part of the area consisted mainly of Diablo flood-plain deposits and that the southern part of the area consisted mainly of Diablo alluvial-fan deposits. The eastern part of the area has lower-zone deposits that consist chiefly of Sierra flood-plain and deltaic deposits from the Kings River in the south and Sierra flood-plain deposits from the San Joaquin River in the north.

The area of highest apparent compressibility of the lower-zone deposits coincides with the area of Diablo flood-plain deposits and Sierra flood-plain deposits derived from the San Joaquin River.

Several lines of evidence indicate that the bedding of the deposits is an important geologic factor controlling the magnitude and rate of compaction computed for the 1943-60 period. The Diablo flood-plain deposits contain abundant and laterally extensive sand beds between fine-grained beds 4-8 feet thick. In contrast, the alluvial-fan deposits have a higher clay content and are more poorly sorted than the flood-plain deposits -characteristics that result in minimum permeabilities and consolidation rates for the fine-grained beds of the fan deposits. Fine-grained beds generally are thicker in the fan deposits (mean bed-thickness factor of 24) than in the flood-plain deposits (mean bed-thickness factor of 14), where the bed-thickness factor equals (aquitard thickness $/ 2)^{2}$.

Thus, conditions in the alluvial-fan aquitards in the southern part of the area have been favorable for development of large residual excess pore pressures and high values of ultimate specific unit compaction. These conditions also are largely responsible for less unit compaction per given amountof increasein applied stress in the southern part of the area between 1943 and 1960.

Thus, evaluation of several geologic factors indicates that the apparent fourfold higher compressibility (specific unit compaction) of the lower-zone deposits in the northern part of the area is part real and part apparent. About a third of the apparent difference in compressibility is real and is due to lesser amounts of total applied stress prior to 1943 in the northern areas. Most of the other two-thirds of the difference is only apparent. It is apparent because it can be attributed chiefly to geologic differences, such as thickness of bedding, that control the rate of expulsion of water from aquitards upon increase in applied stress in deposits of markedly different modes and sources of deposition.

\section{REFERENCES}

American Geological Institute, 1960, Glossary of geology and related sciences [2d ed.]: Washington, D.C., Am. Geol. Inst., Natl. Acad. Sci.-Natl. Research Council, 325 p. with 72 p. supp.

American Society of Civil Engineers, 1962, Nomenclature for hydraulics: Am. Soc. Civil Engineers, Manual and Repts. on Eng. Practice, no. 43 , p. 85.

Bull, W. B., 1964a, Alluvial fans and near-surface subsidence in western Fresno County, California: U.S. Geol. Survey Prof. Paper 437-A, 71 p.

$1964 \mathrm{~b}$, Geomorphology of segmented alluvial fans in western Fresno County, California: U.S. Geol. Survey Prof. Paper 352-E, p. 89-129.

1972, Prehistoric near-surface subsidence cracks in western Fresno County, California: U.S. Geol. Survey Prof. Paper 437-C, $85 \mathrm{p}$.

Bull, W. B., and Miller, R. E., 1974, Land subsidence due to groundwater withdrawal in the Los Banos-Kettleman City area, California-Part 1. Changes in the hydrologic environment conducive to subsidence: U.S. Geol. Survey Prof. Paper 437-E, $71 \mathrm{p}$.

Bull, W. B., and Poland, J. F., 1974, Land subsidence due to groundwater withdrawal in the Los Banos-Kettleman City area, California-Part 3. Interrelations of water-level change, change in aquifer-system thickness, and subsidence: U.S. Geol. Survey Prof. Paper 437-G, $62 \mathrm{p}$.

California Division of Oil and Gas, 1960, Pt. 1, San Joaquin- Sacramento Valleys and northern coastal regions, in California oil and gas fields, Maps and data sheets: $493 \mathrm{p}$.

Carpenter, D. W., 1965, Pleistocene deformation in the vicinity of the Mile 18 pumping plant, in Guidebook for Field Conf. I, Northern Great Basin and California-Internat. Assoc. Quaternary Research, 7th Cong., USA 1965: Lincoln, Nebr., Nebraska Acad. Sci. p. 142-145.

Croft, M. G., 1972, Subsurface geology of the late Tertiary and Quaternary water-bearing deposits of the southern part of the San Joaquin Valley, California: U.S. Geol. Survey WaterSupply Paper 1999-H, 29 p.

Davis, G. H., and Green, J. H., 1962, Structural control of interior drainage, southern San Joaquin Valley, California, in Geological Survey research 1962: U.S. Geol. Survey Prof. Paper 450-D, p. D89-D91.

Davis, G. H., Green, J. H., Olmsted, F. H., and Brown, D. W., 1959, Ground water conditions and storage capacity in the San Joaquin Valley, Calif.: U.S. Geol. Survey Water-Supply Paper 1469, $287 \mathrm{p}$.

Davis, G. H., and Poland J. F., 1957, Ground-water conditions in the Mendota-Huron area, Fresno and Kings Counties, California: U.S. Geol. Survey Water-Supply Paper 1360-G, p. 409-588.

Frink, J. W., and Kues, H. A., 1954, Corcoran Clay-A Pleistocene lacustrine deposit in San Joaquin Valley, Calif.: Am. Assoc. Petroleum Geologists Bull., v. 38, no. 11, p. 2357-2371.

Gilboy, Glennon, 1928, The compressibility of sand-mica mixtures: Am. Soc. Civil Engineers Proc., v. 54, p. 555-568.

Inter-Agency Committee on Land Subsidence in the San Joaquin Valley, 1955,Proposed program for investigating land subsidence in the San Joaquin Valley: Sacramento, Calif. open-file report, $160 \mathrm{p}$.

1958, Progress report on land-subsidence investigations in the San Joaquin Valley, California, through 1957: Sacramento, Calif, open-file report, $160 \mathrm{p}$.

Ireland, R. L., 1963, Description of wells in the Los Banos-Kettleman City area, Merced, Fresno, and Kings Counties, California: U.S. Geol. Survey open-file report, $519 \mathrm{p}$.

Janda, R. J., 1965, Quaternary alluvium near Friant, California, in Guidebook for Field Conference I, Northern Great Basin and California-Internat. Assoc. Quaternary Research, 7th 
Cong. USA 1965: Lincoln, Nebr., Nebraska Acad. Sci., p. 128-133.

Johnson, A. I., Moston, R. P., and Morris, D. A., 1968, Physical and hydrologic properties of water-bearing deposits in subsiding areas in central California: U.S. Geol. Survey Prof. Paper 497-A, $71 \mathrm{p}$.

Lofgren, B. E., 1960, Near-surface land subsidence in western San Joaquin Valley, California: Jour. Geophys. Research, v. 65, no. 3 , p. $1053-1062$.

-1968, Analysis of stresses causing land subsidence, in Geological Survey research 1968: U.S. Geol. Survey Prof. Paper 600-B, p. B219-B225.

1969, Land subsidence due to the application of water, in Varnes, D. J., and Kiersch, George, eds., Reviews in Engineering Geology, v. 2: Boulder, Colo., Geol. Soc. America, p. 271-303.

Lohman, S. W., and others, 1972, Definitions of selected ground-water terms-revisions and conceptual refinements: U.S. Geol. Survey Water-Supply Paper 1988, 21 p.

Meade, R. H., 1964, Removal of water and rearrangement of particles during the compaction of clayey sediments-review: U.S. Geol. Survey Prof. Paper 497-B, 23 p.

1967, Petrology of sediments underlying areas of land subsidence in central California: U.S. Geol. Survey Prof. Paper 497-C, $83 \mathrm{p}$.

1968, Compaction of sediments underlying areas of land subsidence in central California: U.S. Geol. Survey Prof. Paper 497-D, $39 \mathrm{p}$.

Miller, R. E., 1961, Compaction of an aquifer system computed from consolidation tests and decline in artesian head, in Geological Survey research 1961: U.S. Geol. Survey Prof. Paper 424-B, p. B54-B58.

Miller, R. E., Green, J. H., and Davis, G. H., 1971, Geology of the compacting deposits in the Los Banos-Kettleman City subsidence area, California: U.S. Geol. Survey Prof. Paper 497-E, 46 p.

Poland, J. F., and Davis, G. H., 1969, Land subsidence due to withdrawal of fluids, in Varnes, D. J., and Kiersch, George, eds., Reviews in Engineering Geology, v. 2: Boulder, Colo., Geol. Soc. America, p. 187-269.

Poland, J. F., and Everson, R. E., 1966, Hydrogeology and land subsidence, Great Central Valley, California, in Bailey, E. H., ed., Geology of northern California: California Div. Mines and Geology Bull. 190, p. 239-247.

Poland, J. F., and Ireland, R. L., 1965, Shortening and protrusion of a well casing due to compaction of sediments in a subsiding area in California, in Geological Survey research 1965: U.S. Geol. Survey Prof. Paper 525-B, p. B180-B183.

Poland, J. F., Lofgren, B. E., and Riley, F. S., 1972, Glossary of selected terms useful in the studies of the mechanics of aquifer systems and land subsidence due to fluid withdrawal: U.S. Geol. Survey Water-Supply Paper 2025, 9 p.

Prokopovich, N. P., 1963, Hydrocompaction of soils along the San Luis Canal alignment, western Fresno County, California, in Abstracts for 1962: Geol. Soc. America Spec. Paper 73, p. 60.

Sharpe, C. F. S., 1938, Landslides and related phenomena: New York, Columbia Univ. Press., 137 p.

Shepard, F. P., 1954, Nomenclature based on sand-silt-clay ratios: Jour. Sed. Petrology, v. 24, p. 151-158.

Taliaferro, N. L., 1943, Geologic history and structure of the central Coast Ranges of California: California Div. Mines Bull. 118, p. 119-163.

Terzaghi, Karl, and Peck, R. B., 1948, Soil mechanics in engineering practice: New York, John Wiley \& Sons, Inc., 566 p.

Trask, P. D., and Close, J. E. H., 1958, Effect of clay content on strength of soils: Coastal Engineering Conf., 6th, Florida 1957, Proc., v. 6, p. 827-843. 


\section{INDEX}

[Italic page numbers indicate major references]

A

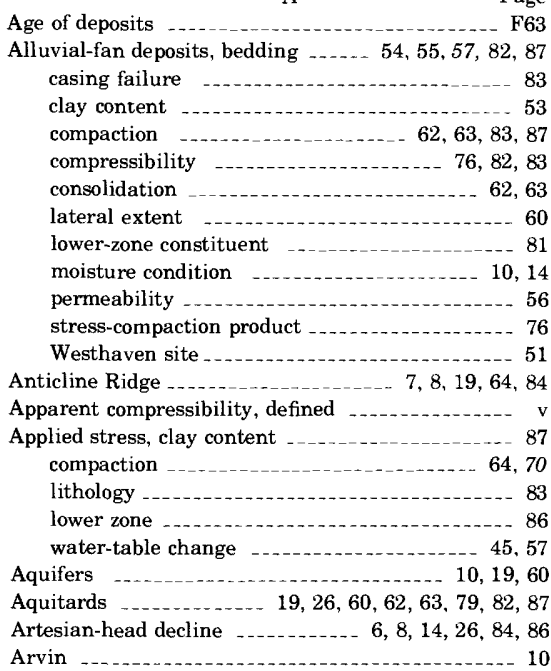

\section{B, C}

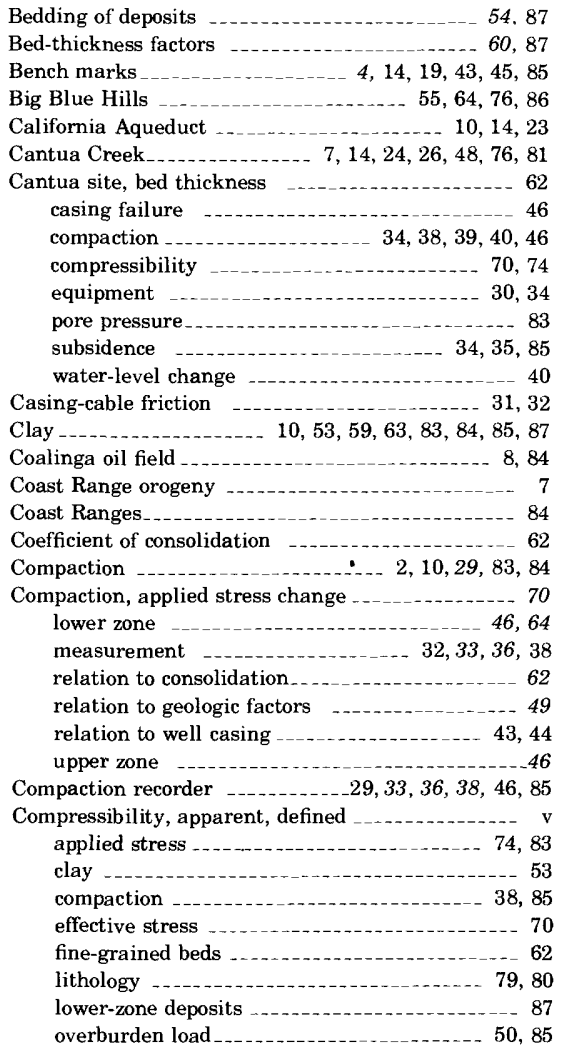

\section{[Italic page numbers indicate major references]}

Compressibility-effective stress product, defined $\begin{array}{r}\text { Page } \\ \text {. }\end{array}$ Compressibility-effective stress product, defined $\ldots$.
Comprion index Compressional forces Consolidation -

Terzaghi theory ............. 54,60 Consolidation coefficient Continental deposits Corcoran Clay Member of the Tulare

Formation $7,38,39,46,47,54,59,63,70,77$ Critical depth _.................... 41 defined.

\section{D}

Damage caused by subsidence _................ 8 Damage to wells Deltaic deposits .............. 53, 58, 61, 63, 81, 82 Delta-Mendota Canal _.......... 14, 26, 49, 84

Deposition Diablo alluvial-fan deposits, bedding $54,55,57$ casing failure clay content $-50,62$ compaction
compressibility
Con consolidation lateral extent _......... 60 stress-compaction product _..._..... 76 Westhaven site
Diablo flood-plain deposits, bedding 51
. clay content _._.............. 53 compaction compaction
compressibility _... deposition -.... 80 lateral extent _............... 59 permeability ...... 56 Diablo Range Diagenetic changes ................... 63

Drawdown ....... 59

\section{E, F}

Effective stress

Elastic compaction

51,70

$-51$ Equipment Etchegoin Formation Expansion - 32 Firebaugh _......... 70 Five Points -, Flood-plain deposits, bed thickness bedding -... $55,56,57,82,87$, clay content ........ 53 compaction -....... 63 compressibility deposition _............ 80, 87 lateral extent _..._. 59 stress-compaction product Fresno slough _..... 19, 64, 70, 85 Friction in equipment

\section{G, H, I, J}

Geologic factors, relation to compaction 49 relation to specific unit compaction -...-...- 67 Ground-water withdrawal ${ }_{--} 1,7,10,33,45,57,67,84$ Hanford
Head decline $\quad F 6,38,59,64,70,85$ Helm oil field Helm oil field
Huron -16 Huron site Inelastic compaction _._. Irrigation -........... 14 Jacalitos Formation

\section{$\mathrm{K}, \mathrm{L}$}

Kerman -.......... 14 Kettleman City . Kings River....... 15, 29, 64, 81, 86 Kreyenhagen Formation .................... 64 Lacustrine deposits . Laguna Seca Hills

Land surface movement

Lateral extent of beds ................ 59

Lemoore site ................ 49, 63

Level-line network

Lithology _._._._._. 54, 57, 58, 59, 76, 83, 86

Little Panoche Creek Los Banos Los Banos-Kettleman City, location _._._..... 2 Los Gatos Creek . _........ 76, 77, 86 Lower zone, artesian head decline ........... 86 compaction . 39,46 deposition _.......... 87 deposits _._. $51,64,79$ lithology specific compaction

\section{M}

Mapping program Maricopa_._._. 10 Marine deposits_____._._._._._. $63,76,81,82,86$ Mendota $14,19,22,26,28,49,85$ Mendota site, bed thickness casing failure compaction equipment _.... 30,33 lacustrine deposits micrologs _permeability _._. pore pressure _........... 83 subsidence -... 33 water-level change - _._._._. 40

Mica _..... 51, 63, 85

Micaceous arkosic sand .

Micrologs _._. 60

Moisture condition

Monocline Ridge -....... 7 Montmorillonite $10,53,85$

$\mathrm{O}, \mathrm{P}$ Oro Loma site, bed thickness
compaction

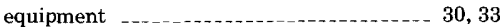
pore pressure subsidence water-level change .......................... 40 Overburden load _... 10,49, 84 Panoche Creek Panoche Hills 
Page

Particle-size analyses ............ F 77, 82 Permeability Petroleum withdrawal

Petrology Pore pressure - $26,51,54,62,79,82,87$ Potentiometric level _._. $6,56,70,86$

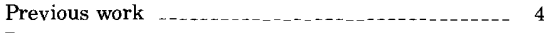

Purposes -...-

\section{Q, R, S}

Quality of lower-zone water Rate of compaction Rate of consolidation Rate of subsidence $\ldots \ldots 2,6,8,9,10,19,22,33,84$

Resistivity $\quad 55,76,77,86$

Reversal of subsidence rate

Richgrove site

Salinity of the lower-zone water

San Joaquin _........... 81

San Joaquin Formation

San Joaquin River

San Joaquin Valley

San Luis Cana

$10,14,18,23,37$

Sand

$10,14,18,23,37$
$52,57,59,63,83,85$

Seepage stress
Sierra deltaic deposits Sierra flood-plain deposits, bedding-- $55,56,82,87$ bed thickness compaction deposition deposition stress-compaction product

Sorting of the fan deposits________ 57 Specific-unit compaction ________ $51,54,63,64,86$ Stress-compaction product $\quad 79,80,82,86$ defined..........

Subsidence damage near-surface defined relation to petroleum withdrawal relation to tectonic movement $\ldots$ relation to well-casing shortening _____-_ 37,44 relation to withdrawal of ground water _._._. 10 Surface-water imports $15,26,27,29,84$

\section{T. U, V}

Tectonic movement $6,7,84$

Terzaghi theory of consolidation

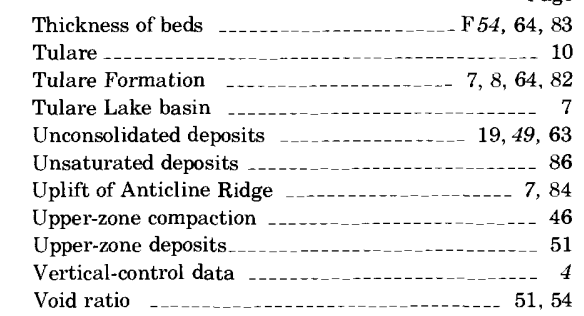

W, Y

Warthan Canyon Wasco _..-- 10

Well-casing failure Well-casing shortening and protrusion -

site, compaction equipment _._._. $30,35,42$ head decline -...... 41 overburden load _.. 51 pore pressure subsidence Yearout site _._. 49,64 